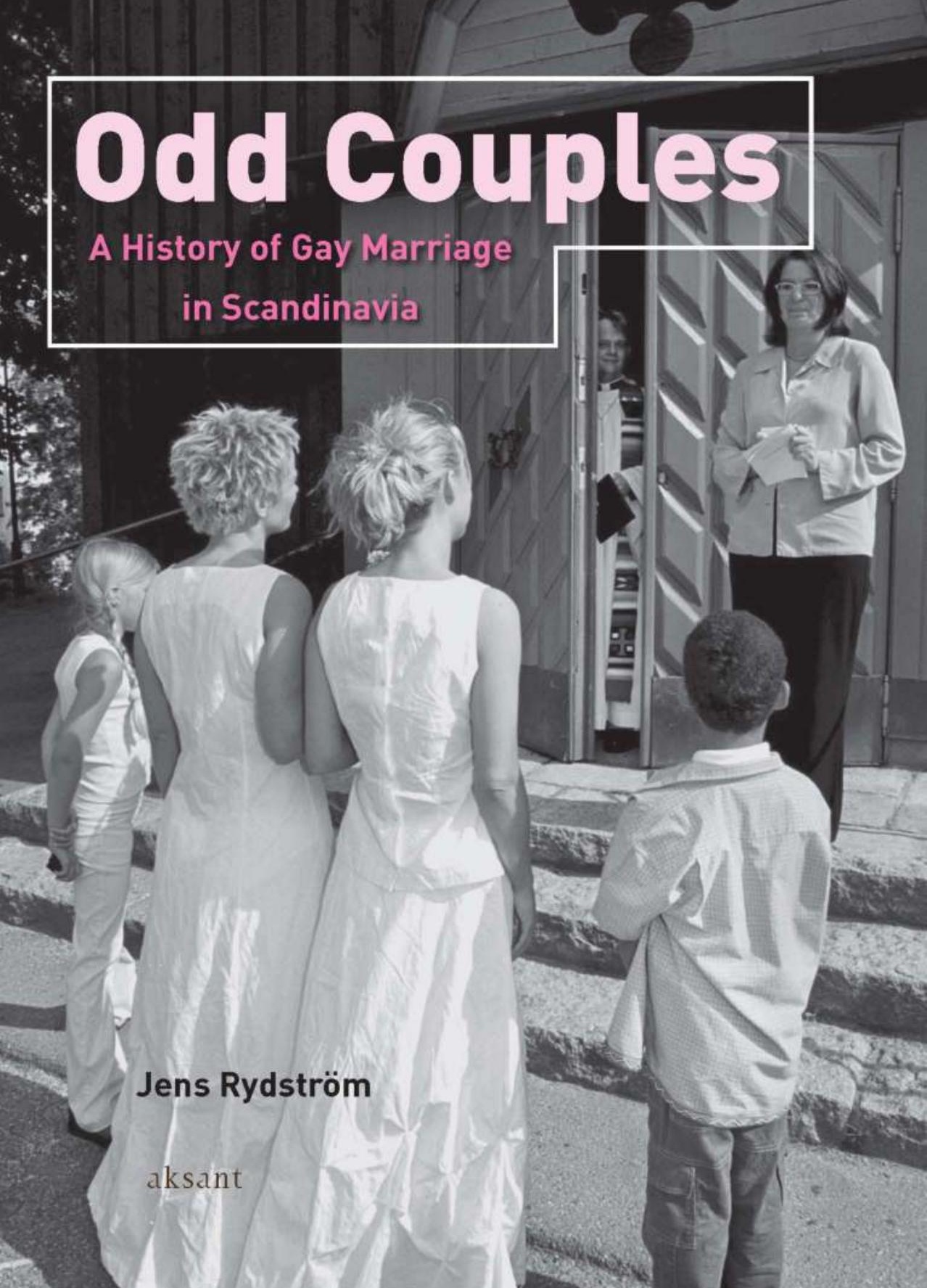




\section{Odd COUPLES}


For Martin 


\section{ODD COUPLES}

A History of Gay Marriage in Scandinavia

Jens Rydström

aksant

Amsterdam

2OII 
isbn $97890526038 \mathrm{I} \circ$

(C) Copyright 2oII Jens Rydström / Aksant Academic Publishers, Amsterdam University Press, Amsterdam.

All rights reserved, including those of translation into foreign languages. No part of this publication may be reproduced in any form, by photoprint, microfilm or any other means, nor transmitted into a machine language without written permission from the publisher.

Cover design: Jos Hendrix, Groningen

Photo cover: Elisabeth Ohlson Wallin

Cover: The cover photo shows a "Church Stair Wedding" in Stockholm 2001. Registrar Kristina Rennerstedt performs the registration ceremony, while parish priest Lars Gardfeldt waits for the couple to enter the Church to be blessed. The Swedish Bishops formally banned partnership registrations inside the Church between $200 \mathrm{I}$ and 2009 .

Aksant Academic Publishers/AUP, Herengracht 22I, IoI6 BG Amsterdam, The Netherlands www.aup.nl 


\section{Contents}

Preface 7

Introduction II

Chapter One: The road to registered partnership 39

Chapter Two: Is marriage what we want? 69

Chapter Three: Gay marriage in mainstream politics 9I

Chapter Four: Implementation II5

Chapter Five: Gender and marriage statistics $\quad$ I27

Chapter Six: The next step $\quad$ I45

Summary and conclusions $\quad$ I67

Notes $\quad$ I79

Appendix: Political parties and gay and lesbian rights groups in Scandinavia $2 \mathrm{I} 3$

References 22I

Index 239 



\section{Preface}

Two events around 1990 marked the beginning of a new era for gay and lesbian rights movements around the world. The first was the introduction in Denmark in 1989 of a law on registered partnership that granted same-sex couples legal recognition nationally. On I October 1989, eleven gay couples registered their partnerships in the City Hall of Copenhagen and met the world press on the City Hall Square - incidentally an old cruising ground for gay men. The second event was the application for marriage licences in Hawaii by one gay and two lesbian couples. They were rejected, but three years later the Hawaii Supreme Court ruled that it was a violation of the state's Constitution to deny marriage licences to same-sex couples. ${ }^{\mathrm{I}}$ Not only did these two actions set the agenda for the majority of the gay and lesbian movements in Europe and the United States for the next decade, but they also signalled the two paths that the political work for gay and lesbian rights would take on each side of the Atlantic. Whereas the U.S. gay marriage lobbyists have relied on court decisions and have waged their struggle for marriage rights mostly in the judiciary, their European counterparts have strived to influence national parliaments and the European Parliament to pass laws and recommendations for the recognition of same-sex couples. Another difference between the European and U.S. experience is that some U.S. jurisdictions have moved directly to full marital rights for gay and lesbian couples, resulting in strong counter movements that in many cases have managed to obtain reverse decisions prohibiting same-sex marriages or civil unions. In Europe, the legislators in general first granted limited marital rights to samesex couples and then alleviated or abolished one limitation after the other, thus paving the road for full marital rights. In a way, the European model has proved more successful, in that it has gradually worn down the opposition to same-sex marriage, with the ironic result that the Christian Democratic parties that first opposed the laws on registered partnership have later defended them as more appropriate for same-sex couples.

For various reasons, it was the gay and lesbian movements in Scandinavia that first succeeded in introducing the idea of a legal regulation of same-sex relationships in the general political debate, but it was far from self-evident that marriage was what the gay and lesbian movements wanted. We will explore the ways in which the gay and lesbian communities discussed the issue of gay marriage from the I970s onward and how mainstream politicians responded to their 
demands. Personally, I was a bystander to this process and did not take part in these discussions. Instead, I was rather heavily involved in activism for the International Lesbian and Gay Association (ILGA) in the r980s and did not participate at all in the lobbying for registered partnership. When the law on registered partnership was adopted in Sweden in 1995, I remember I was happy but not profoundly moved. It was more like I felt when Sweden won the bronze medal at the I994 world championship in soccer. I had had absolutely no interest in soccer before, but when the unexpected good results of the Swedish national team affected everyone around me, I found myself cheering in front of the TV set. For me, gay marriage became a personal choice when Sweden got the law in I995, and my partner and I discussed whether or not to register our relationship. I wanted to do it, because I wanted to have a fun party to celebrate, but my partner dismissed the whole thing as "petit-bourgeois rubbish." After two years, I managed to persuade him, and we had a great party. Afterwards, we both agreed that the moment in front of friends and families felt more significant than we had expected, and that state recognition was not unimportant. To register partnership - to marry - was a political action, to be sure. It was demonstrated by the fact that the advertisement announcing our union that we wanted to place in the local newspaper Smälänningen caused the summoning of an extra editorial board meeting, or so we heard. They accepted the advertisement, but a little later we were reminded by an anonymous letter we received that the change of attitudes in society was not complete. The letter contained our wedding advertisement, on which someone had scribbled "shame on you both." Even if we smiled at this rather meek protest, it made us aware that the partnership registration, just like a wedding, was a public ceremony, and that recognition takes place on several levels. These experiences were part of the process that gave me the idea for this study. What did the formal recognition of a couple mean? And how does state recognition of same-sex couples affect society?

This book is based on research carried out in 2003-2005 for a project funded by the Swedish Council for Working Life and Social Research (FAS). I searched archives and interviewed activists and politicians in all five Nordic countries as well as the autonomous areas of the Faroe Islands and Greenland. ${ }^{2}$ As I write this preface, the news reaches me that Portugal has become the sixth country in Europe to allow marital rights for same-sex couples. So it is about time for me to put a stop to my project.

I want to thank all those who shared their experiences with me, and also the volunteers in the gay and lesbian archives in each country, in particular Hanne Bielefeldt and Karl Peder Pedersen from LBL in Denmark, Jussi Nissinen from SETA in Finland, Porvaldur Kristinsson from Samtökin ' 78 in Iceland, Espen Ophaug from LLH in Norway, and Stig-Åke Petersson from RFSL in Sweden. In Finland and Iceland, where my language skills were insufficient, Anna Heino and Hrafnkell Tjörvi Stefánsson provided help in finding and interpreting 
important documents for me. I also want to thank Peter Edelberg and Hans W. Kristiansen, who have read the whole manuscript and given me valuable advice, and Leif Pareli, who has given me advice on some of the intricacies of Norwegian lesbian and gay history. My dear friends Porvaldur Kristinsson and Kati Mustola patiently explained various aspects of Icelandic and Finnish society to me and generously shared their knowledge of queer history in those countries. Last, but certainly not least, I thank Glenn Rounds for patiently correcting my English.

The publication of this book has been made possible by a generous grant from the Royal Swedish Academy of Science and from FAS, the Swedish Council for Working Life and Social Research, for which I thank them. I also want to thank the San Michele Foundation, which made it possible for me to work with the manuscript during three wonderful weeks of work and leisure on the Isle of Capri.

Finally, I want to thank my life companion since 1984 and registered partner since 1997, Martin Loeb, to whom I dedicate this book.

Lund, December 2010 



\section{Introduction}

When registered partnership was introduced in Sweden, the Justice Department distributed an information folder about the new law. Its front page showed two male figures, dressed in funny clothes and funny little hats and holding a red heart. They had thick red lips and large pants and coats. They were unmistakably clowns. Inside the folder was a list of the new law's limitations. Registered partners were not allowed to adopt children, neither individually nor as a couple. They were denied access to insemination or any other kind of assisted fertilisation, and they could not be appointed as legal trustees or have joint custody of under-age children. Furthermore, they had no right to a church wedding, and at least one of the partners had to be a Swedish citizen residing in the country. However, the folder stated that they had the right to carry the same family name, and this was illustrated by two female figures in front of a door with the arch-Swedish name Olsson on it. Just like their male counterparts they had big red lips and large staring eyes. They were blond and conventionally feminine, in a grotesque sort of way. ${ }^{\mathrm{T}}$

How the Swedish Government chose to visualise the law on registered partnership in 1995 is deeply disturbing. By offering terms similar to those for heterosexual couples but with the above restrictions, the state was prepared to incorporate homosexuals in the majority culture in ways that would make them completely harmless. Who could be afraid of these silly clowns? They posed no threat whatsoever to the majority's children or to the adults' immune systems. Moreover, being pictured as very blond and very blue-eyed Swedish Olssons signalled that the law was for Swedish citizens. It can serve as a reminder that, ever since they were first introduced, the laws on registered partnership in the Scandinavian countries have been connected with national identity. Opponents of the laws feared that their home country would be shamed internationally, while a growing majority saw it as a source of national pride, as if the perceived tolerance and open-mindedness of their Government had in some way worn off on themselves. ${ }^{2}$

Furthermore, the similarity of the members of each couple in the folder can be read as a sign of an ideal internal equality in terms of age, class, ethnicity, and race. The modern homosexual couple was thus to be seen as one in which the two persons resemble each other in every possible way and whose ultimate unifier is their family name. There was no room for children in the picture. Ac- 
"Law on registered partnership. In force from 1 January 1995." The official information folder of the Swedish Ministry of Justice. Unknown artist. Print: Norstedts tryckeri, Stockholm 1994.

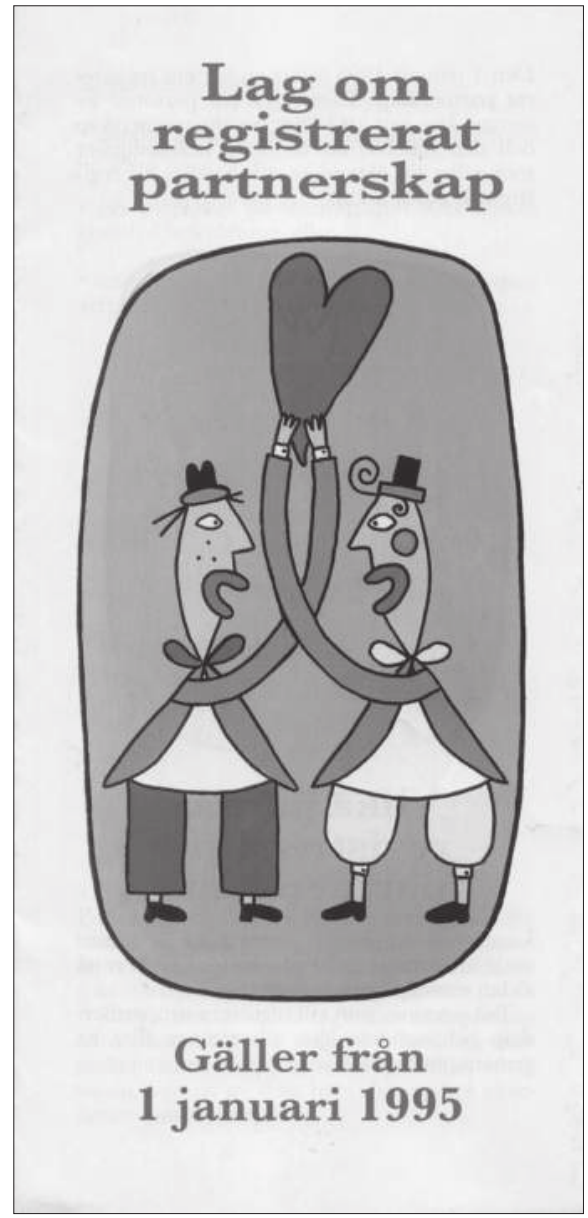

cording to the Swedish Justice Department in I995, the homosexual couple was blond and barren.

The decade after the introduction of the law, however, saw a gradual change, the abolishment of one after the other of the limitations that made registered partnership less than a marriage. The rule that at least one of the partners must be a citizen and residing in the country was abolished, so that it sufficed if one of the partners was a permanent resident. The restriction that the registered partnership was valid only in Scandinavia was lifted, and various forms of religious blessing have become incorporated in the national churches' liturgy. However, the most important amendments of the laws - and the hardest to achieve - have concerned parental rights. By now, all Scandinavian countries grant the right to apply for adoption, ${ }^{3}$ and all allow lesbian couples in registered partnership access to assisted fertilisation. In 2009 both Norway and Sweden introduced gen- 
Registrerade partner får inte

- adoptera barn, varken gemensamt eller var fờ sig,

- ges möjlighet till insemination eller annan konstlad befruktning, eller

- utses att som särskilt fórordnade förmyndare gemensamt ha vårdnaden om en underărig.

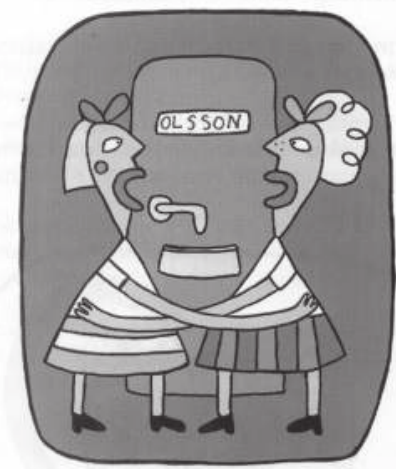

\section{Vilket efternamn?}

Partnerna kan senast vid registreringen välja mellan att ha den enes efternamn som gemensamt efternamn eller att behålla sina efternamn från tiden närmast före partnerskapet.

En partner som har tagit den andres efternamn kan bära sitt tidigare efternamn som mellannamn. Om partnerna har olika efternamn, kan en av dem bära den andres efternamn som mellannamn.
Inside, the folder explains that: "Registered partners may not adopt children, neither together nor separately; be given access to insemination or other artificial fertilisation; or be appointed as guardians to have joint custody of a minor." However, they may carry the same last name. Information folder, Swedish Ministry of Justice. Print: Norstedts tryckeri, Stockholm 1994.

der-neutral marriage laws and abolished their existing laws on partnership. Iceland followed suit in 2010 thus marking the end of an epoch of special legislation for gay and lesbian couples in these three countries.

State recognition of same-sex couples has occurred in two steps. First, legal recognition of childless gay or lesbian couples was introduced, in spite of considerable political opposition, between 1989 (Denmark) and 2002 (Finland). The second step was the recognition of so-called rainbow families, i.e. granting parental rights to same-sex couples with children. This has happened gradually through changes in the laws on adoption and assisted fertilisation, as well as through various adaptations of family law. When Norway, Sweden, and Iceland finally introduced full marital rights for both same-sex and different-sex couples, the differences between registered partnership and marriage were already very small. There has been remarkably weak political opposition to these stepby-step adaptations, and when full marital rights for same-sex couples were in- 
troduced, the debate was limited and the nay-votes in Parliament few. It is this two-step development this book is about. We will first explore how the idea of legal recognition of same-sex couples was debated within the gay and lesbian movements in the Nordic countries and how this idea was adopted by mainstream politicians. Then we will investigate how registered partnership gradually became more and more like "real marriage." The analysis will concentrate on the changing discourses of gay marriage in Scandinavia, from scepticism in the gay and lesbian movements and in society at large, to the all-embracing enthusiasm of contemporary Scandinavian society. ${ }^{4}$

Part of the problem with state recognition of same-sex couples is the regulatory benevolence that some say weakens the position of these couples instead of strengthening it. In the 1995 leaflet the well-meant concern of the state was inadvertently condescending, and much of the pro-gay rhetoric of mainstream politicians evolved around a paternalistic will to "help" homosexuals lead a decent life. On the one hand, the official recognition of a relationship is important for individual couples in matters of inheritance, loans, pensions, and residence permits. For some international couples, it is literally a matter of life and death if their relation is not recognised by the authorities. From the perspective of many same-sex couples in Scandinavia, the introduction of partnership laws has made a world of difference, especially since they allowed for joint custody of children. But on the other hand, the price for official recognition is a loss of cultural diversity and political significance. The more lesbians and gays become part of the majority culture's value system, the harder it is for them to criticize it.

\section{Questions raised}

The aim of this study is to explore the process leading to legal recognition of same-sex relations and the subsequent widening of the scope of the laws. The analysis is on two levels, one dealing with the work for and against the laws within the gay and lesbian communities and the effects they have had on them, and the other with the origins and effects of the laws in Scandinavian society. On the first level, we will examine how the activists in gay and lesbian movements have discussed gay marriage and how they have formulated their strategies from the I970s to the present. A gender-sensitive analysis is necessary to understand the dynamics between gay activists and lesbian feminists. Also, we will examine how the attitudes differed between activists in different countries in the Nordic region.

On the second level, we will investigate when and why mainstream politicians began listening to the demands of gay and lesbian activists. The political processes leading to the introduction of registered partnership laws differ slightly between the countries in Scandinavia, but there are enough similarities to regard these differences as regional variations of a common theme. How did the 
different political parties respond to gay and lesbian activists' demands? What gender and generational differences determined the ways in which gay marriage became a mainstream political issue? Finally, we will put these two discourses in their historical context and analyse them in connection with political and discursive changes during the period. The AIDS epidemic affected the construction of "homosexuality" both on a local and national level in each Scandinavian country. How important was it for the partnership law and how did it influence the political work for the law? How did the political landscape and the foundations of the Scandinavian welfare states change in that same period? The political spectrum in the Scandinavian parliaments changed drastically in the r97os and I980s, and the partnership reform took place in an unusually unruly political landscape. The question why these reforms came first in Scandinavia and not in any other place is perhaps the most difficult to answer, and the analysed material does not allow a definitive answer to this question. But by studying regional differences within Scandinavia, the book will open up a discussion that is relevant to the question.

The effects of the laws will also be discussed on two levels. What were their effects for gay and lesbian couples, and how have queer people responded to the legislation? Again, gender plays an important role. Do the laws carry different meanings for lesbian couples than for gay couples? Has this changed since the laws were first adopted? It is difficult to give general answers to such questions, but I intend to let statistics speak. Are the laws differently viewed in different Scandinavian countries? And on the general level, what effects can we spot in Scandinavian society as a whole? How have twenty years of existence of the laws influenced public attitudes?

We will see how lesbians and gay men transcend the last barriers of the heteronormative majority culture and invade the institutions of the welfare state. When parenthood is granted even to same-sex couples, and when gay and lesbian identity is less about sex and increasingly about child rearing and hetero-like family matters, will that change the discursive framework around the family? How will it affect the sexual landscape of the nation? U.S. anthropologist Gayle Rubin has theorised about the "sexual hierarchy" that gives credit to some sexual practices and stigmatises others. In what she calls "the charmed circle," we find "good" sexuality: practices within marriage that are intended to procreate. Outside the circle are all the variations of sexual expression that are stigmatised by society: sex outside marriage, sex for money, sadomasochism, homo- and bisexual practices - all practices for pleasure and not for procreation. What happens when this order of things is disturbed, now when homo- and bisexual practices have moved inside the "charmed circle" and gays become parents? The practices that, according to Rubin, are branded by society as "sick, sinful, 'way out" were previously conceptually and spatially closely related to the homosexual and the bisexual. ${ }^{5}$ Will they now be left outside the circle, with less resources and less 
"semi-decent" friends who can speak for them, or do they profit from the successful integration of their more fortunate sisters and brothers?

\section{Theoretical points of departure}

It is hard to say what is lost to queer culture when it is integrated in the majority society. The queer criticism of gay marriage has almost exclusively been formulated in a U.S. context, where gay marriage or civil unions are not a reality on the national level, and where some of the arguments are strikingly similar to those voiced by lesbian feminists and radical gay men in Europe before the laws were passed. These arguments focus primarily on the loss of solidarity with other oppressed groups and criticise gay marriage for being a gay male middle-class project. ${ }^{6}$ One argument is that the political campaign for marriage takes activists' time and energy away from other pressing issues such as health care and solidarity. Another is that the campaign has provoked a counter campaign that now threatens the rights of U.S. lesbians and gays even where they have once been granted, as happened in California in 2008, when the right for same-sex couples to be married was revoked after a referendum. ${ }^{7}$ The U.S. context, however, is very different from the European one, and in societies like Denmark, where registered partnership has been a reality for more than twenty years, the question is no longer about policy-making. The pros and cons of marriage have largely become relegated to private discussions among gay and lesbian couples.

This book will show that the discussions about alternative lifestyles that were common in the I970s and early I980s all but disappear toward the end of the century. Dreams about collective living and extended families have been replaced by ideas of the ideal couple. Alternative lifestyles have clearly suffered a setback, but perhaps that would have come even without the partnership laws.

The symbolic meaning of state recognition of same-sex couples is not to be underestimated, but the question remains whether the price for that has been a higher degree of regulation when it comes to kinship. As U.S. queer theorist Judith Butler has pointed out, "the topic of gay marriage is not the same as that of gay kinship," and it is not good to give one up in order to get the other. ${ }^{8}$ But still, it seems that the changes we have witnessed in marriage law mirror a development on a deeper level, a new way of thinking about marriage and family. French anthropologist Claude Lévi-Strauss' theories about kinship presupposed and reproduced a heterosexually structured system, based on men's traffic in women, as Gayle Rubin convincingly has argued. 9 The incest taboo and the prohibition against endogamy are, according to Lévi-Strauss, the basis itself for society as it is possible for us to picture it. In fact, the very intelligibility of culture is built on these structures of kinship. Judith Butler has drawn on that idea and used the Greek tragedy Antigone to comment on gay marriage and kinship. Traditionally, Sophocles' play has been read as a symbol of the defiance of power, 
of the last remnant of kinship-based society, resisting in vain the abstract state with its absolute demands on its citizens.

Butler asks what would happen if Antigone instead of Oedipus had been the basis of modern psychoanalytic theory. The catastrophic kinship position of Antigone as the offspring of the incestuous relation between Oedipus and Jocasta detaches her from the start from a heterosexual and reproductive normative structure. She shuns marriage and even life, when she seeks death in a symbolic incestuous act, as she insists on mourning and burying her dead brother who is at the same time her nephew. According to Butler, Antigone positions herself outside the normative structure that enables us to understand culture and causes a catachresis - a misapplication of the words that define kinship. However, the catachresis that emerges out of this situation presents a new way of understanding:

What emerges is a melancholia that attends living and loving outside the liveable and outside the field of love, where the lack of institutional sanction forces language into perpetual catachresis, showing not only how a term can continue to signify outside its conventional constraints but also how that shadowy form of signification takes its toll on a life by depriving it of its sense of ontological certainty and durability within a publicly constituted political sphere. ${ }^{\circ}$

Traditionally, those who choose unconventional ways of constructing their close relationships are constrained by the lack of institutional confirmation to live in ontological uncertainty, since there are no officially endorsed terms to designate their way of living. The gap between what language can describe and a lived reality that escapes simple description forces them to invent their own conceptual universe. The catachresis, the usage of a word in a sense contrary to its original meaning, is then typical for how people outside the norms of society use language to designate themselves and their lives. Queer people will speak about "my husband," "my wife," or "my family" when society denies their very existence. At different times they have performed what Canadian historian Elise Chenier has called "freak weddings," staging and sometimes exaggerating the paraphernalia of heterosexual wedding ceremonies. By these appropriations of the norm they expose themselves to its disciplining mechanisms, but they also keep challenging it and proposing new meanings. ${ }^{\text {II }}$

Registered partnerships, civil unions, and gay marriages thus undo the norm just by presenting not one alternative but many. In light of Butler's analysis, however, it is possible that the change in legal ramifications of same-sex relations that we witness now in Scandinavia - the replacement of the laws of registered partnership with a unified marriage law - will strengthen heteronormativity and impoverish the conceptual reality of same-sex couples. The Dutch way of keeping a law on registered partnership open to both same-sex and dif- 
ferent-sex couples and to open up traditional marriage for same-sex couples allows greater freedom of choice, but the hegemonic position of the couple is still there, and no provisions exist for those who want to join their lives in greater numbers than two.

The mild coercive manners of Scandinavian society were perhaps best described by French philosopher Michel Foucault, who in a 1978 interview said that his early work Histoire de la folie (I96r) was written under the influence of his experience as a guest lecturer in Sweden and Poland in the r950s. In the interview, he described Swedish society as "an 'over-medicalized,' protected society where all social perils were in some ways attenuated by subtle and studied mechanisms." The disciplining mechanisms of modern society that Foucault outlines are remarkably visible in Scandinavian society. There is an unusually strong loyalty to the state in Scandinavian societies. ${ }^{\mathrm{I} 2}$ Finnish social historian Pauli Kettunen has pointed out that none of the Scandinavian languages makes any clear distinction between "state" and "society." There are different words for the two concepts, but according to Kettunen they are most often used synonymously. ${ }^{13}$ This strong loyalty to the state is a prerequisite for the willingness to pay high taxes and to accept state intervention in private lives, and it also makes public opinion susceptible to attitude changes in accordance with political decisions.

In Surveiller et punir (1975), Foucault describes how Western society since the Enlightenment has deployed increasingly subtle means of control, making early modern methods of punishment and coercion obsolete. By developing panoptical systems of surveillance, the agents of power do not have to use force to discipline the citizens, who instead will internalise the demands put upon them and act as "docile bodies" according to the norms laid down for them. The acceptance and assimilation of homosexual citizens in Western society can be examined in the light of Foucault's analysis, and questions about the loss of agency that a formerly marginalised group suffers when it is incorporated in society must be asked. ${ }^{14}$ Discussions about homonormativity - i.e. the internal disciplining process exerted by gay activists themselves - will be touched upon, but the main focus will be on the political processes leading up to the introduction of the partnership laws in Scandinavia, their effects on society, and their transformation from regulating the lives of childless pairs to also including childrearing rainbow families. ${ }^{15}$

Another theoretical inspiration that has influenced this study comes from Nancy Fraser. In Justice Interruptus (1997) and later work she has outlined an analysis of political agency in the "post-socialist condition," after the end of the Cold War. There are two kinds of politics, she writes, the "politics of redistribution," which attends to the problems caused by uneven distribution of wealth, and the "politics of recognition," which is about the problems that arise from the disdain shown to certain groups in society. German philosopher Axel Honneth 
has claimed that disdain within an ethical community is as detrimental to humans as institutional discrimination, and together with Fraser he has discussed the theoretical foundations for a politics of recognition. In these discussions, Fraser has demanded a dual approach in order to meet the needs of a politics of justice. Recognition of minority groups and redistribution of wealth would then be equally important political projects. ${ }^{16}$ The relevance to my study is obvious. During the I99os, the same period of time as laws on registered partnership for same-sex couples were adopted in one country after the other, politics of recognition played an increasingly important role in mainstream politics. Much of the process leading to legislation concerning lesbian and gay rights is to be understood as the effect of an increased emphasis of the politics of recognition, and this book will explore the forms this took within the Scandinavian political system.

The historical process I specifically want to investigate is thus the development toward state recognition of same-sex couples and, subsequently, of rainbow families. ${ }^{17}$ In other words, I want to study how the core of the laws has changed from merely codifying the relationship of the barren clowns described in the beginning, toward regulating the social life of potential child-rearing couples and queer families. U.S. literary scholar Lee Edelman and others have discussed queerness in terms of "death" and "life," claiming that queers, formerly inscribed in a discourse of death and sterility, become increasingly "folded into life," to quote Jasbir Puar. ${ }^{18}$ And indeed, this is exactly what has happened within the framework of civil unions and gay marriage. In order to understand the discursive change from death to life in the history of gay marriage, we must, however, be aware of both temporal and geographical differences. To begin with the geographical differences, the access to children, to Edelman's "reproductive futurity," for same-sex couples, has been less contested in the United States than in Europe. While many European states have been willing to grant legal recognition to gay and lesbian couples, they have been much more reluctant to give them joint custody over children. In a work on the French Pacs, the unwillingness of French authorities to include children in it was described thus: "It's all about opening the couple to homosexuality, but not the family." Politicians and scientists have united in their efforts to keep children out of the French and European versions of legally recognised unions between same-sex couples, but on that condition they were willing to let them register. ${ }^{19}$ In the United States the situation has been the opposite. As a general rule, it has been much easier for lesbian and gay couples to adopt children than to obtain legal recognition for their relationships. Part of the explanation of this difference is probably that many more children are up for adoption in the United States than in Europe, so while European childless couples - straight and gay - have to depend on international adoptions, U.S. couples can easily find domestic children in need of parents. Another reason might be the stronger position of the family versus the 
state in the U.S. compared to Europe. Even though the state's prerogatives differ between different countries, European state power as a rule retains a greater possessive claim on its future citizens. Finally, European welfare measures are directed toward individuals to a much higher degree than in the United States, where the family unit remains the prime recipient of welfare. This means that legal recognition of same-sex relationships potentially entails much higher costs in the U.S. than in Europe. ${ }^{\circ}$ A more systematic comparative study of the history of gay rights in Europe and the United States would provide valuable insights into the different ways these issues have been dealt with.

The change over time is central for this book. One of the most challenging tasks for a historical investigation is to understand the processes that led to the acceptance of the partnership laws by the political majority. In order to be accepted, the laws had to be presented as something other than the radical project to abolish marriage that was presented by the left socialist parties in Denmark and Sweden in 1968 and 1973, respectively. In the I980s the law was indeed redefined as a social liberal project based on arguments of human rights, equality, and justice and thus could be fitted into the broad welfare state project of Scandinavian social liberalism and social democracy. The other change which is of interest for this study is the discursive shift from barrenness to fecundity. The limitations listed in the original laws on registered partnership were there to bar same-sex couples from full equality with different-sex couples, and the most important of these were the different ways same-sex couples were to be denied access to children. ${ }^{21}$ In a debate in the Swedish Parliament in 1976, MP Gunde Raneskog from the Centre Party (Centerpartiet) declared that "heterosexuality bears life, development, and future within. Homosexuality harbours sterility, barrenness, and death." ${ }^{22}$ In unusually clear language, Raneskog put in words what had long been the dominant way of thinking about homosexuals. Such comments would now be highly improper within the Scandinavian political establishment, but the general idea that procreation and the future are reserved for the heterosexual majority was not challenged until very recently, when rainbow families began demanding recognition at all levels of society - from daycare centres to career jobs. U.S. literary scholar Judith Halberstam has theorised about queer time and space and concludes that the queer time as lived by nonheterosexual, non-gender-conformative people differs dramatically from what is lived by those who follow the heteronormative pattern of marriage, childrearing, grandchildren, and death. We must ask ourselves, she argues, what happens when queers are more and more involved in a heterosexual matrix through marriage and childrearing. ${ }^{23}$ And it is relevant to see the adaptation of same-sex couples to the surrounding norms as something that profoundly changes their role in society. To use Lee Edelman's metaphor, the Child has become attached to the image of the happy homosexual couple, and - at least in Edelman's view homosexuals have ceased to be queer. ${ }^{24}$ But if not queer, what are they? I would 
argue, based on empirical research, in agreement with Edelman, that the assimilated homosexual citizen is no longer perceived as a threat to the nation, nor as a constructive agent of political change.

The integrated homosexual couple in Scandinavia has become a symbol for the majority's tolerance. When 8o,0oo Icelanders celebrate Reykjavík Pride - in a nation with 320,000 inhabitants - it is not only the manifestation of a creative subculture but also of a majority culture staging an impressive example of their own tolerance. The well-adjusted lesbian, gay, and transgendered citizens parade as symbols, whose main purpose is to be passive recipients of tolerance. There is a growing frustration among many queers that they are suffocated by understanding and acceptance. Some of the most interesting political agents are now to be found among the young, who do not (yet?) live in couples or raise children. ${ }^{25}$

But that is only part of the picture. For Scandinavian rainbow families, those with children to raise and a responsibility reaching beyond their own lives and generational concerns, are not only folded into life, but into the networks of the welfare state. Everyday in maternity wards, day-care centres, and in meetings with teachers and youth leaders, they encounter the latent homophobia that thrives in all layers of society, and in a sense they are the vanguard of social change. A less flattering factor is the role that some openly gay and lesbian politicians play in politics. It is not to be expected that they adopt a progressive, tolerant and humane attitude to other groups in distress. In 2008, self-declared gay and bisexual men in the Swedish Government upheld its refusal to grant hospital care to paperless refugees, thereby representing, in Puar's words, a homonationalist lobby that combines a xenophobic discourse with gay rights rhetoric. In the Netherlands, the xenophobia combined with pro-gay politics of the Pim Fortuyn List is a well-known and notorious example. ${ }^{26}$ In this book, I will map the development of the homosexual construct. I will examine how "homosexuals" have evolved from a childless minority on the margins of society to represent a reproductive segment of the majority culture, sometimes in compliance with xenophobic and neo-conservative nationalist discourses, and sometimes as agents for social change on an everyday level.

\section{Method, material}

Since I989, the Danish model of partnership has spread to all Scandinavian jurisdictions except the Faroe Islands, and to many other countries, in Europe and elsewhere. From 200I, however, when the Netherlands opened up their marriage law to same-sex couples, gender-neutral marriage laws have been introduced in several countries and are being prepared in others. Were the laws on registered partnership thus only a parenthesis in history, a step toward full legal recognition of same-sex couples on the same terms as different-sex couples? 
This way to frame the question would be to assume that modern queer history consists of a necessary chain of events that inevitably leads to full recognition of monogamous same-sex relations that in no way differ from the publicly endorsed procreative heterosexual family unit, a much too simplistic interpretation of history. It is an assumption narrowly centred on the experience of Western culture, whereas in reality the struggles for recognition in a globalised world take on different and more complex forms. How is one to understand the cultural clashes between Western gay-friendly liberalism and homophobic governments in many African countries? And the lack of it in others? A comparative study of gay rights in South Africa and Zimbabwe could perhaps shed light on some of the most pressing issues in present-day human-rights work. ${ }^{27}$ In order to understand the complexities of the development of gay, lesbian, and queer identities in a globalised world, it is necessary to acknowledge the simultaneous development of different understandings of same-sex desire. U.S. literary scholar Eve Kosofsky Sedgwick wrote long ago that many sexualities coexist at any given time, and that the multifaceted experience of queer life seldom follows a set pattern. But historians necessarily study change and operate with a "before" and an "after," and historians, as all researchers, need to generalise their results. Before the laws on registered partnership, Scandinavian non-heterosexuals lived under different conditions than after their enactment, regardless of whether the laws were the cause or result of discursive change. ${ }^{28}$

How, then, is one to avoid historical determinism when describing a political process of the kind described in this book? If by historical determinism we mean the idea that history evolves in a necessary, predetermined fashion toward higher and higher stages of perfection, then there are many reasons to avoid it. For one thing, it would be bad history, based on a post-factum interpretation of past events. Another reason is that such history conveys an image that we now live in the best of conceivable worlds and that our just rulers or democratic institutions have lifted our society from the tyranny and arbitrary power of past times. That kind of history has always legitimised power. However, the ambition to present an alternative history poses methodological problems. Describing a before and an after makes it hard to avoid the narrative being interpreted as a necessary chain of events. The genealogical method developed by Michel Foucault leaves us at a loss when we try to formulate an anti-determinist history. My main objection to Foucault, as will be clearly demonstrated by this book, is that he leaves out historical agency in his analysis. He has masterfully pointed out the problems of determinist historical writing, and his analysis of power production in modern society is empirically demonstrated again and again. But as he does not leave room for historical change as a result of conscious action by collective or individual subjects, I find his methods hard to use in a historical account built on empirical evidence and aimed at explaining change. ${ }^{29}$ 
The kind of historical determinism that downplays the importance of the historical actor must be rejected. It is not unimportant who is in power and what directions social movements take. Even if material conditions and discursive boundaries limit the ways in which history can evolve, historical agents are crucial in understanding it. The main actors in this study are the gay and lesbian activists and the politicians who listened to their demands. Gay and lesbian organisations and political parties appear as collective actors in a political arena consisting of legislative bodies and mass media. However, they seldom speak with one voice, so in order to understand the political process it is necessary to point out and analyse internal differences and cleavages within these groups.

The main sources of this study are interviews, official print, documents, and newspaper clippings from the archives of gay and lesbian movements in Denmark, Finland, Iceland, Norway, and Sweden. The interviews were partly transcribed and the tapes and transcripts are in my possession. They were held in Scandinavian languages, except for some of the interviews in Finland and Iceland where English was used. The archives of the gay and lesbian movements in Denmark, Finland, Iceland, Norway, and Sweden have also provided important information, such as correspondence, policy documents, and minutes of board meetings and general assemblies. Together, these sources give insights into the ways gay and lesbian activists thought and discussed at the time, and the documents and the interviews together offer a comprehensive picture of the debate around gay marriage over the last four decades. The gay and lesbian archives in each country also contain collections of newspaper clippings. The most complete collections are in Finland, Iceland, and Sweden. A methodical examination of these long series of clippings has presented a picture of the general debate in Scandinavia during the same time..$^{\circ}$ Finally, the official publications of the parliaments in all Scandinavian countries have provided information about the political process leading up to the partnership laws.

The interviewees have been selected among key persons within the lesbian and gay movements in all Scandinavian countries and their political allies on a parliamentary level. I have chosen not to interview conservative opponents to the laws on registered partnership, since the focus of the study lies in the debate within the gay movements and their interaction with the political establishment. Thus, I have focused on those lesbian and gay activists who were engaged in the debate on gay marriage and those politicians who actively worked for a law on registered partnership. In order to understand how these laws could be adopted so quickly in Scandinavia it is important to study the processes that led to more or less unanimous demands from the lesbian and gay movements. For this reason, I have interviewed both those lesbian and gay activists who were for the law and those who were against it. On the other hand, the politicians who worked for the laws can probably provide the best information about the process which led to the acceptance of the idea of registered partnership within 
their respective parties. Interviews with the opponents to the idea of registered partnership or gay marriage within the political establishment would provide information about the strategies and turnabouts in a dwindling political resistance against these reforms, but for this study I have concentrated on the agents of change.

The different types of written material and the interviews supplement each other, thus rendering a more complete image of the political process. Interviews in a historical study of this type carry with them problems concerning the accuracy of memory and the interference of layers of other memories deposited over the once fresh and direct experience. Many of the written sources are historical remains, i.e. documents generated as an immediate result of an act or a process, but others, like the newspaper clippings, are mediated narratives about past events. I have carefully evaluated each source and cross-checked interviews with remaining documents or contemporary newspaper reports. There is no way of reaching a true and complete description of events past, but by a careful analysis of different types of sources we can arrive at a plausible version of the lived experience of the historical actors.

One important insight from feminist methodology is the importance of the researcher's own subject position. U.S. philosopher Donna Haraway has stressed that all knowledge production is a political act and that if the researcher conceals her or his subject position, the reader is deprived of the possibility of evaluating the work critically. Though I sympathise with Haraway's analysis and agree with large parts of it, I find it difficult to combine a full-fledged standpoint theory with queer theory's project of destabilising identity politics. ${ }^{3 \mathrm{I}} \mathrm{How}^{-}$ ever, I do agree that the researcher's position is important. The conclusions of this study would be different if they had been reached from a conservative angle or from a feminist anti-gay-marriage position. I myself believe that the reform of registered partnership furthered a process of increased human rights that has strengthened democracy and participation in society for more people. But since I also see things from a queer activist position I am aware of many complications that the process of assimilation has brought with it to the world's LGBTQ communities. The question of what has been lost with increased openness and acceptance is important for understanding contemporary society. "Greater sexual freedom has brought immense gains but it has its costs," says Jeffrey Weeks in a 2007 book. ${ }^{32}$ These costs will be discussed in the final chapter.

\section{Previous research}

The first historical accounts of the making of the Scandinavian partnership laws were written by activists who had worked hard for them, and they are accordingly inspired by feelings of triumph. When gay activists Bent Hansen and Henning Jørgensen wrote about the new Danish law in the 1993 ILGA Pink 
Book, they emphasised the lobbying efforts of the Danish National Union for Gays and Lesbians (LBL). Downplaying the internal differences within their organisation, they claimed that the discussions for and against the law within the gay and lesbian community were held by a minority, whereas "most gays were interested merely in obtaining recognition from society and in having their practical, legal, and economic problems solved." ${ }_{33}$ By describing the feminist and radical opponents to the law as a small and isolated group opposed to a practical solution of ordinary people's problems, they conveyed an impression of internal unity, and they avoided mentioning that no lesbian couples were registered during the first day's celebrations. The Norwegian lobbying effort is documented in an unpublished report from the joint Partnership Group of Norway's two national gay and lesbian organisations. Their 37-page report gives more space to the opponents of the law and outlines the different arguments put forth within the movement. Among other things, it describes in detail how the Norwegian national gay and lesbian organisation's 1973 decision not to support gay marriage was gradually reinterpreted in order to make it possible for the organisation to work for registered partnership modelled after the Danish law. It does not, however, comment on the personal animosity that some of the debates generated, and it avoids going into great detail when it comes to the discussion of principles within the movement. The chair of the working party, Kjell Erik Øie, wrote a chapter in a Festschrift to the former chair of the Norwegian gay and lesbian movement, Karen-Christine "Kim" Friele. She was once against the law, but understandably Øie does not dwell on the personal conflicts between himself as a lobbyist for the law and Friele as an opponent. ${ }^{34}$ Swedish jurist Hans Ytterberg's account of the history of the Swedish law is also written from a basically positive perspective, and concentrates on legal issues. From the viewpoint of a Member of Parliament, the dramatic history of the Swedish partnership law was described by Liberal MP Barbro Westerholm in an article written six years after its adoption, for the fiftieth anniversary of the Swedish gay and lesbian organisation. Westerholm was chair of the Government's Partnership Commission and in her article she exposes the foul play that many of the new law's political opponents engaged in to block it. Written from the perspective of a gay-friendly liberal politician, Westerholm's article naturally does not address internal differences within the gay and lesbian movement, but it gives interesting insights into the dynamics in her own party and in the corridors of the Riksdag. In a similar manner, Kristin Halvorsen, who later became leader of the Norwegian Socialist Left Party (Sosialistisk Venstreparti) and Norwegian Minister of Finance, dedicated a chapter in her autobiography to the law on registered partnership. She was one of the young MPs from different parties who in 1990 signed the first private members' bill to the Storting demanding a law similar to the one already in force in Denmark. In her book she reveals how the fact that her brother is gay has been an important factor inspiring her to give priority to 
the question of gay marriage, and she describes how she and the other signers of the bill had to struggle with older and moral conservative forces within their respective parties. ${ }^{35}$

Apart from the memory books and accounts from centrally placed persons there soon appeared a number of publications addressing the question why the laws on registered partnership were adopted, and why it happened first in Denmark/Scandinavia. Norwegian political scientist Ingvill Størksen analysed how the attitudes expressed in public debate in Denmark and Norway had changed in both countries. Størksen concluded that the concept of homosexuality was radically redefined in public discourse from the I970s on. The political will to control homosexuality first declined when sodomy was decriminalised and then it increased again with a new emphasis on social engineering within the framework of the welfare state. Without the redefinition of homosexuality, pro-gay legislation would not have been possible, she claimed. ${ }^{36}$

Danish sociologist Henning Bech and historian Wilhelm von Rosen both described the Danish law as an effect of a development in which "homosexuals" would soon disappear as a category. When Bech enumerated the arguments for and against the partnership law in Danish public debate i987-90, he noted that both proponents and opponents of the law evoked Denmark's international reputation. Those who were against the law were afraid that Denmark would be shamed internationally and those in favour of it wanted Denmark to be a beacon for gay and lesbian rights. The law on registered partnership became possible, even necessary, in a society where the homo/hetero dichotomy was losing its meaning. Even though Bech noted that "lesbians generally may have been more reserved towards the legislation than were the gay men," he did not linger on the gender differences in the debate. ${ }^{37}$

Danish historian Birgitte Søland also discussed the reasons the law on registered partnership was introduced first in Denmark. She pointed out the pragmatism of the arguments from the gay and lesbian movement and the lack of substantial arguments from the traditionalist opponents to the law. The arguments in favour of the law emphasised that it was a practical way of solving legal and administrative problems for same-sex couples and they were not necessarily founded on principles of equality and justice. She referred to Bech's and Rosen's discussions about the disappearance of homosexuals, but unlike them she saw the partnership law as a "double-edged sword." While it is true that the law has enhanced the civil rights of lesbians and gays, she wrote, "the political construction of homosexuals as fundamentally like heterosexuals and the insistence on conformity and normative gender behavior among homosexuals might well prove the ultimate obstacles to liberation for all gay men and lesbians." ${ }^{8}$

According to Danish historian Karin Lützen, the law was possible because the status of marriage had been devalued during decades. At the same time, she warned against the effects of too much assimilation to society. The original- 
ity and innovative lifestyle of lesbians and gay men risked being compromised, she wrote. ${ }^{39}$ Norwegian Sociologist Rune Halvorsen shared this view. The law strengthened the heteronormative order, he claimed, since it was specially aimed at homosexuals and inscribed homosexuals as the necessary other. (To be sure, the Norwegian variety of the law stated that "two homosexual persons of the same sex" may register their partnership, thus explicitly forging a homosexual identity.) He also pointed out that the low number of couples who had actually registered as partners in Norway (in 1998) proved that the law was imposed from above by an elite of educated middle-class lesbians and gays and their allies. Halvorsen was the only one in the early debate who applied a class perspective, but otherwise he shared some of the thoughts of the other analysts, like the idea that lesbians and gays risked losing their distinctive culture by becoming assimilated in society; that registered partnership was possible to achieve only when marriage was devalued; and that the symbolic value of the law was more significant than its practical value, in spite of the pragmatic line of argument from its proponents. ${ }^{40}$ Norwegian anthropologist Turid Markussen has commented on Halvorsen's discussion and agreed with his criticism of it as fundamentally ambivalent. It both excludes and includes homosexuals by defining homosexuals as a marginal group and then reaching out for them in a gesture of tolerance and solidarity. However, Markussen gives the law credit for also destabilising given norms. "The otherness that the law regulates is at the same time made visible, and it may just as well lead to a questioning of heterosexuality as a normalising force." ${ }^{41}$

Most male scholars commented on the scarcity of resistance to the law from within the gay and lesbian movement, a fact that Rune Halvorsen explained by "a kind of self-imposed censorship, and as pronounced realism regarding what can be thought, said, told, and done." ${ }^{22}$ Henning Bech noted that there was a fear homosexuals would be assimilated in society at the expense of their difference and otherness, but he concluded that "such 'radical' views were ... rare in the total amount of public debate, and were mainly put forward by a few lesbians and gay men." To explain why there was no resistance against the law within the movement, he assumed that "the majority of both gays and lesbians simply considered it an extension of their possibilities of choice and social acceptance." ${ }^{43}$ Both Søland and Lützen, on the other hand, commented on the absence of lesbian support for the law, and Søland concluded that many lesbians were put off by a law that did not allow access to adoption or assisted reproductive technology to same-sex couples. Lützen saw it as an effect of "the good girls" victory over "the bad girls" in the movement and connected it to the feminist debate within the U.S. lesbian movement that peaked during the I980s. She deplored the good girls' victory and wrote that she couldn't help feeling that she was "a member of a lesbian housewives' league." ${ }^{44}$ In a recent study, Swedish Gender Studies scholar Anna Adeniji has examined marriage resist- 
ance among women in Sweden. Based on focus-group interviews with women who have declared that they do not want to marry, it is constructed as a synopsis for a sit-com with five fictional characters representing views ranging from liberal feminist to radical feminist. They all have different reasons to resist marriage, and, in the end, discuss the consequences of gender-neutral marriage legislation. In this study of post-modern Swedish feminist women, the resistance to same-sex marriage is mainly focused on a critique of the patriarchal foundations of marriage and on the privilege it gives to individuals in two-person partner relationships. ${ }^{45}$ In an unpublished Ph.D. thesis, sociologist Anna Einarsdóttir has mapped the experiences of registered partnership among non-heterosexual women in Iceland. Based on interviews, documents, and statistics, she traces the historical development that led to the adoption of the law, and evaluates its effects on the non-heterosexual community. She concludes that the law has had positive effects on the whole, but that the picture is more complicated on the personal level. In spite of positive effects, such as an easier acceptance of their family of origin, the official status of their relationship can expose their sexuality to the public in an unwanted way. Her findings challenge the notion that tradition has a fading importance. Instead, she claims, "same-sex marriage both heightens the importance of tradition within non-heterosexual relationship cultures, while also challenging the heterosexual underpinnings of the institution of marriage." 46

Why did it happened in Denmark first? Henning Bech has evoked the Danish concept of frisind or "freemindedness," which he described thus: "In its idealized form, it does not simply denote permissiveness, but enlightened tolerance in matters of personal belief and moral conduct, combined with a social commitment to establish the conditions for individuals to think and live as they prefer." 47 The concept of frisind, inspired by nineteenth-century Christian philosopher N.F.S. Grundtvig, shapes much of Denmark's national self-image, but this explanation nevertheless seems a bit far-fetched. In reality, the frisind is something that distinguishes Denmark from the other Scandinavian countries, and since the laws on registered partnership were adopted more or less simultaneously all over Scandinavia, it would be wiser to look for explanations in what unites the different Nordic countries rather than what separates them. The common denominator most obviously suited to explain the political development leading to the laws on registered partnership is the structure of the Scandinavian welfare states. With their secular foundation and strong emphasis on equality and fairness, they are an ideal ground for the kind of social politics that nowadays results in recognition politics aimed at integrating - and assimilating - various kinds of minorities in society. ${ }^{48}$

On the other side of the Atlantic, tensions within the North American gay and lesbian movement rose from the end of the I980s, when conservative activists began building the "conservative case" for same-sex marriage. Gay rights 
lobbyist Andrew Sullivan expressed his conviction that same-sex marriage "harnesses" the homosexual minority, and "enlists them in the conservative structures that liberationists find so inimical." 49 By appealing to conservative values like family, monogamy, and children, Sullivan and others provoked a response from conservative forces in the United States that had an unexpected impact in the general debate about same-sex marriage. Social anthropologist Stanley Kurtz seized the opportunity to discuss gay marriage in a conservative context. He wrote a number of articles which claimed that the institution of marriage was deteriorating in Scandinavia, mainly because of sexual permissiveness and the encouragement of non-heterosexual lifestyles. Several scholars have countered his arguments, accusing him of using available data wrongly and of finding causal links where there were none. The debate soon developed into a battle of how to interpret Scandinavian marriage statistics. Kurtz's critics claimed that there were no causal links between registered partnership and a decline in the number of marriages and an increase in the number of divorces. Moreover, they accused Kurtz of misinterpreting data and failing to see that Scandinavian marriage statistics in reality show a steady increase in the number of new marriages. ${ }^{5 \circ}$ Kurtz's arguments were nevertheless picked up by the conservatives in the United States and played an important role in the debates about the "defence of marriage" legislation. His articles were widely publicised, and in 2004 his principal articles were read into the U.S. Congressional Record. Referring to Kurtz's work, a senator claimed that "marriage in Scandinavia and in Holland is dying since the advent of same-sex marriage over the last decade in these countries." ${ }_{51}$ The Scandinavian and Dutch experiences thus had some relevance to the U.S. debate on gay marriage, and they have been used as an argument both for and against gay marriage in the United States.

Another type of argument was put forth by progressives within the gay and lesbian movement and its academic allies. Already in 1999, Michael Warner contested the conservative case for gay rights presented by gay columnists like Andrew Sullivan and Michael Signorile, and in his influential book The trouble with normal, Warner warned against conformist politics. Inspired by Erving Goffman, he suggested that gays and lesbians embrace their stigma and celebrate their distinctiveness instead of anxiously seeking recognition from the majority. ${ }^{52}$ Lisa Duggan, professor of American Studies at New York University, has also criticised the gay and lesbian movement for putting too much emphasis on gay marriage. For almost a decade, she has criticised the lesbian and gay movement for buying into a neoliberal economic agenda, and in subsequent articles she has discussed homonormativity as a concept for the increasing mainstreaming of lesbian and gay activism and for its complicity in a potentially oppressive world order. Not only has the question of gay marriage provoked a backlash, which has had detrimental effects on gay and lesbian rights, she wrote, but it has also implied a politics that upheld unfair discrimination against single 
persons and failed to acknowledge the changing patterns of U.S. family life. "If pursued this way, the drive for gay-marriage equality can undermine rather than support the broader movement for social justice and democratic diversity." Instead, she advocated recognition of various domestic arrangements and seemed to lean toward a European model of partial legal recognition in the form of civil unions or domestic partnerships. "By treating marriage as one form of household recognition among others, progressives can generate a broad vision of social justice that resonates on many fronts," Duggan wrote together with U.S. journalist Richard Kim in 2005, and outlined a strategy that would connect the question of gay marriage to the question of social reform..$^{53}$ According to U.S. historian Paul Robinson, the "queer wars" in the United States are a result of the establishment of a gay conservative lobby, which in turn is the result of gay and lesbian culture's integration in society. When any manifestation of same-sex love was unanimously condemned by society, a conservative pro-gay stand was inconceivable, he argues, but when gays and lesbians become more and more accepted, it is possible to combine a homosexual lifestyle with opinions to the right. And, together with gays in the army, the question of gay marriage has become a shibboleth of new gay conservatism. ${ }^{54}$

George Chauncey's Why marriage? is a history of gay marriage in the United States. Chauncey puts the debate in a U.S. historical context and draws parallels to the civil rights movement and to the ban of interracial marriages. In his analysis, he shows how the idea of gay marriage is not alien to U.S. history but follows as a logical step on the striving for equality between different groups in the multi-cultural and multi-racial U.S. society. ${ }^{55}$ The polarised debate on gay marriage within the U.S. gay and lesbian movement is probably an effect of gay marriage's being so strongly contested by the traditional right in the United States. If we compare it with the situation prior to 1989 in Scandinavia, the arguments and the political positions are remarkably similar, with an anti-gay marriage grouping consisting of lesbian feminists and politically radical gays propped up against a moderate or conservative group of gay men.

In their book For better or worse, U.S. legal experts William Eskridge and Darren Spedale have the explicit aim of describing the Scandinavian experience of registered partnership laws in order to demonstrate to a U.S. audience that the regulation of same-sex relationships does not lead to any harmful effects for society. Based on a great number of interviews, newspaper clippings, and archival material, their book offers to date the most comprehensive discussion of Scandinavian laws on registered partnership. Step by step, Eskridge and Spedale trace the history of the laws, demonstrate their beneficial effects for the individual couples and for society at large, and describe the changing nature of the debate and the legal contents of the laws since they were first adopted. In a final chapter they outline the lessons to be drawn from the Scandinavian experience for the U.S. debate on gay marriage..$^{66}$ What they don't do, however, and which I 
want to do, is to discuss more in detail the political and historical contexts that have made the laws possible in Scandinavia and the effects they have had on Scandinavian society. Eskridge and Spedale's book is a contribution to a North American discussion of gay marriage, thus the historical and geographical contexts are limited. Inspired by Kees Waaldijk's theory of small change, which will be presented below, they describe the historical development as following a set path, thus leaving aside the political dynamic that has resulted in the Scandinavian laws on registered partnership. Also, its clear-cut tendency omits the possible alternatives to registered partnership or gay marriage that were an important part of the debate in Scandinavian gay and lesbian circles. They contend that "as gays and lesbians have been integrated into the mainstream, average citizens have become aware that gay people are just as variegated a group as any other, and most gay people are rather normal in most respects." ${ }^{77}$ Without further questioning the concept of "normal," they do not discuss the normative and normalising dynamics in society and the possible role of partnership laws in the strengthening of heteronormativity.

Within legal studies, Israeli jurist Yuval Merin's 2002 comparison of U.S. and European legal initiatives to recognise and regulate same-sex relationships is one of the best sources for understanding the structures and legal effects of the laws on registered partnership. It lacks a historical perspective, but it offers the best comprehensive study of various legal constructions of the regulation of same-sex couples..$^{8}$ U.S. theologian Mark D. Jordan questions the will of gay couples to marry, as well as the conservative resistance to their demands. "The traditional Christian wedding" is not traditional at all, he claims, but only accidentally Christian. Jordan shows that what are most often interpreted as belonging to a Christian tradition were just secular traditions appropriated by the Church, and that the confusion of what marriage actually is inevitably makes it difficult to argue about it in other than emotional terms..$^{59}$

U.S. economist M. V. Lee Badgett has conducted various research projects on the economy of lesbians and gay men, in which she has challenged myths of gay affluence and shown how discrimination in the work market has effects on the economic situation of queer people. In her recent book, When gays marry, she makes a broad survey of the consequences of the partnership laws in $\mathrm{Eu}-$ rope and possible outcomes of such reforms in the United States. By means of interviews, mainly conducted in the Netherlands, as well as statistical data, she investigates the impact of these laws on the heterosexual majority culture and on the lesbian and gay community. Her conclusion is that even if "the right to marriage comes at a cost," the overall result of registered partnership laws has been beneficial to lesbians and gays, and indeed to the whole of society. ${ }^{60} \mathrm{In}$ that process, heterosexual marriage does not seem to become less popular in any way. In the heated U.S. debate, her aim is to find common grounds for a discussion of the potential benefits and dangers of gay marriage reform. Moreover, 
she presents a large-scale comparison between a number of countries divided in a first and second wave of recognition of same-sex unions, and one group that does not recognise such unions, and concludes that three factors seem important for a country's willingness to introduce laws on registered partnership or gay marriage. A high proportion of cohabiting heterosexual couples, a low percentage of evangelical adherents and a high overall tolerance of homosexuality are factors that facilitate gay marriage reform. That way, Badgett can also predict which jurisdictions are probably next in line to introduce legal recognition of same-sex couples. The weakness of such a large-scale comparison is obviously that some of the factors found seem rather obvious, but it nevertheless gives a good overview of the development in a large number of countries. It also links the European and U.S. development together in a way few other studies have done. In my book, I intend to present a more in-depth analysis of the development in just a few countries, but my results are on the whole in harmony with Badgett's. ${ }^{6 \mathrm{I}}$

The most impressive collective contribution to legal research about samesex partnerships was the result of an international conference of legal experts in London in 1999. Legal recognition of same-sex partnerships is a collection of forty-two articles analysing, discussing, and presenting proposals and existing laws regulating same-sex relationships in twenty-three countries on all continents. The first section discusses theoretical questions and philosophical and legal foundations for the regulation of same-sex relationships, and the following sections treat national, European, and international law. In the foreword, Robert Wintemute declares that the book offers no space for traditionalist arguments against this kind of legislation, since the traditional view, "largely derived from the doctrines of dominant religions ... has powerful exponents who have no trouble making their voices heard." On the other hand, the book offers some discussion of diverging views coming from the gay and lesbian community, but since most of the articles are written by jurists who have argued for legal recognition of same-sex relations, it is safe to say that the feminist and radical criticism of gay marriage is underrepresented. Some scholars who contribute to it, like Davina Cooper and Janet Halley, express their understanding of the feminist critique but conclude, nevertheless, that gay marriage is fully compatible with a feminist view. ${ }^{62}$

In a theoretical essay, Kees Waaldijk has formulated the "law of standard sequences," meaning that in general each jurisdiction proceeds with a gradually increased recognition of homosexuals in society, beginning with the decriminalisation of homosexual acts, usually accompanied by a higher age of consent for homosexual than for heterosexual sexual acts. The following steps are, according to Waaldijk, I) to equalise the ages of consent, 2) to enact various kinds of legislation prohibiting discrimination on grounds of sexual orientation, and 3) to introduce laws recognising same-sex relationships and parenting. Furthermore, 
Waaldijk proposes a "law of small change," which he formulates thus: "Any legislative change advancing the recognition and acceptance of homosexuality will only be enacted if that change is either perceived as small, or if that change is sufficiently reduced in impact by some accompanying legislative 'small change' that reinforces the condemnation of homosexuality." ${ }_{3}$

Seemingly unequivocal empirical evidence sustains Waaldijk's first law, at least regarding the countries in Northern Europe. Homosexuality was decriminalised in all Scandinavian jurisdictions between 1933 (Denmark) and 1972 (Norway). The higher age of consent for homosexual relations was abolished between 1972 (Norway) and 1999 (Finland), and anti-discrimination laws have been enacted between 198I (Norway) and 2006 (Faroes). ${ }^{64}$ The "law of small change" holds true for Scandinavia and most of Europe, and the introduction of the laws on registered partnership is a history of negotiating various limitations of their scope and a gradual narrowing of the gap between registered partnership and "real marriage." However, it does not fit in to the development in many countries, like the United States and some others, where backlash is mixed with sudden improvements in legal conditions for lesbians and gays. The assumption that the development follows set patterns and evolves due to historical necessity is a rather simplified interpretation of seemingly interconnected facts. Waaldijk's laws are valid in Europe, not as determinants of a path that history must follow, but as reasonable historical generalisations.

However, Waaldijk's observations highlight the difference between the European experience and that of the United States. The "step-by-step" tactics that European lobbyists for gay marriage have chosen have been successful, whereas the "all-or-nothing" policy that large parts of the U.S. gay and lesbian movement adopted has been counter-productive, at least at this moment in history. Rather than formulating a "law of small change," one would be better advised to talk about recent developments in terms of "path dependency." Welfare state research confirms that choices in the past have a determining effect on possible outcomes of social politics. Thus the road chosen by the Danish gay and lesbian movement has probably had a decisive influence not only on Danish politics, but also on those of neighbouring Scandinavian countries, and probably on Dutch, German, and French politics as well..$^{65}$

In Europe, the crucial difference between a northern, corporatist, way and a southern, universalist, way of dealing with registered partnership, stems from traditions of particularism and universalism. In Scandinavia, Germany, and the United Kingdom, the laws on registered partnership and civil unions were special laws, created for a minority of same-sex couples only. In contrast, when the Netherlands and France introduced the law on registered partnership and the Pacte de solidarité civile (Pacs), respectively, they opted for laws that were open to both different-sex and same-sex couples. Since the Netherlands opened civil marriage for same-sex couples in $200 \mathrm{I}$, Dutch legislation applies universalist 
principles to both kinds of legal regulation of the couple. Both the marriage law and the law on registered partnership are open to same-sex as well as to different-sex couples. In France, however, the universalist principle only applies to the Pacs. Civil marriage is closed to same-sex couples, and is thus a particularist law, designed only for one type of couple, the heterosexual. Sociologist Laurent Chambon has discussed this and a number of other problems with the idea of universalism in France, which he describes as a universalist particularism that submerges alternative lifestyles in the majority. He is especially concerned with the fact that so few French politicians have come out as lesbians or gays, and he attributes that fact to the pressure from the majority and the absence of visible institutions for the lesbian and gay minority. ${ }^{66}$ French jurists Daniel Borrillo and Pierre Lascoumes have shown how the French Left have had problems to come to terms with the idea of a law for same-sex couples. As it was finally conceived, the homosexual remained inferior to the heterosexual. Also on a practical level, the universalist principle, as it was applied to the Pacs, in reality had the effect of rendering invisible the lesbian and gay minority. For years, it was impossible to obtain data from French Statistics on the number of same-sex couples who registered and compare it to corresponding data for different-sex couples, something which provoked irritation among demographers. ${ }^{67}$ The Pacs has been further discussed by sociologist Eric Fassin in a collection of essays dedicated to l'inversion de la question homosexuelle. In this collection, he offers a somewhat brighter picture, calling attention to how the "homosexual question" has indeed become a majority issue, as it successfully puts homophobia and heteronormativity under scrutiny. The French republican institution of Pacs, he claims, which has been opened to (childless) gay couples, is one of the best examples of how society's institutions are forced to question its own normativity. ${ }^{68}$

German research on registered partnership (eingetragene Lebenspartnershaft) has been extensive, but with few exceptions it consists of legal studies, and the historical perspective has been largely absent. However, Roland Schimmel and Stefanie Heun's contribution to Wintemute and Andenæs' anthology on legal recognition of same-sex partnerships in Germany, also contains an update on the work for legal reform until 2000. ${ }^{69}$ And in 200 I five authors from as diverse fields as sexology, theology, sociology, and law published a study which provided a comprehensive scholarly discussion about same-sex relationships in a German context. In this volume, sociologist Rosemarie Nave-Herz presented the historical roots of marriage and the legal regulation of cohabitation, but she did not discuss the political process behind the decision. Mareike Dittberner's 2004 study of registered partnership and children's rights provides a rich legal discussion of different aspects of registered partnerships in Germany, but also fails to give the full historical perspective. The legal-historical perspective is perhaps best covered by Kirsten Gerhard, whose comprehensive study of the German partnership law also provides an analysis of its legal history. ${ }^{\circ}$ Die Homo-Ehe 
from 200I, written by journalist and gay activist Stefan Mielchen, summarises the historical development toward registered partnership, and also provides a rich documentation in the form of law texts and speeches in Parliament. His historical account, from the failed but highly publicised litigation campaign of 1992, via the local Hamburg partnership provisions, to the final decisions in the Bundestag is to date the best historical account of a dramatic moment in the history of lesbian and gay rights in Germany. ${ }^{71}$

The overall European development has been studied by sociologists Maks Banens and Rommel Mendès-Leite. In a 2008 report to the French Ministries of Employment and Health, they investigated similarities and differences between various European laws and also offered a historical background. The similarities lie in the kinds of restrictions imposed, compared to marriage laws, and that these restrictions are in the process of gradually being lifted. The dissimilarities lie above all in the frequency of partnership registrations per capita in each country, with Sweden at the bottom of the list and the Netherlands and U.K. at the top. Banens and Mendès-Leite do not apply a gender analysis to their data, which in my view gets in the way of a thorough analysis of the partnership dynamics. ${ }^{72}$

At a conference in Stockholm in 2003, Henning Bech warned against some of the effects of the partnership laws. An army of "greedy sociologists" stands ready, he said, to present research on the new category: officially registered gay and lesbian couples. He urged the scholars in the audience to stay away from these couples, to leave them in peace, and instead write new stories of love and jouissance. ${ }^{73}$ But it seems that his words were in vain. There is indeed a growing body of research on registered gay and lesbian couples from a sociological and demographical point of view. Gunnar Andersson and Turid Noack have studied demographical patterns of partnership registrations and dissolutions in Norway and Sweden, and established that same-sex couples have a much higher divorce rate than different-sex couples, and - which seems to go against common belief - that lesbians divorce twice as often as gay men. On the other side of the Atlantic, Esther Rothblum, Kimberley Balsam, and Sondra Solomon have studied same-sex couples in Vermont, Massachusetts, and California and found that the gender differences include that the men are older and have waited longer to legalise their relationship, and the women more often have children from previous different-sex relationships. Demographic studies use available data to provide profiles of the lesbian and gay population. In a nationwide U.S. study from 2000 , the authors show that the same-sex cohabiting population is highly concentrated in big cities, that the men have served in the army less frequently, but the women more frequently, than in the general population. Moreover, gay men earn less than other men, whereas lesbians earn more than other women. A California demographic study from 2008 suggests that $37-46$ percent of gay men and $5^{\mathrm{I}-62}$ percent of lesbians aged ${ }^{-18}-59$ are in cohabiting 
partnerships. This is slightly less than the 62 percent of heterosexuals in the same age-span who live together. This kind of research can indeed be seen as part of the legitimising dynamics and, since it concentrates on family structures, it is in itself a sign of the paradigm shift that has resulted in same-sex couples and families being considered a part of life rather than associated with "sterility, barrenness, and death." 74

The restructuring of the family was the topic of much research toward the end of the twentieth century. Apart from studies that explicitly have dealt with same-sex family constellations, like Kath Weston's Families we choose (I99I), many studies have analysed the changing patterns of intimacy on a broader scale. Anthony Giddens, Jeffrey Weeks, and others have theorised about the transformation of families and its effects on society. Most researchers of family patterns agree that the establishment of socially recognised same-sex family constellations is one of the most important factors in contemporary society that contribute to the redefinition of the family concept. However, it is also generally accepted that the concept of family is in constant flux and that we are not witnessing a historical change of apocalyptic proportions, as some conservative commentators would have it. Rather, the ideal of a nuclear family could be seen as a historical parenthesis. ${ }^{75}$ The recognition of same-sex parents has generated sociological and psychological research since the I970s, when a series of trials concerning lesbian mothers' right to their children created a demand for knowledge about the well-being of children with same-sex parents. In 200I, U.S. sociologists Judith Stacey and Timothy Biblarz claimed that much of the research that was aimed at testing the suitability of gay parents would downplay the difference between them and different-sex parents, out of fear of strengthening the political argument against gay parenting. This sparked a debate about the research question itself, and British sociologist Stephen Hicks dismissed Stacey and Biblarz as reinforcing essentialist notions of homosexuality and heterosexuality. Instead, he emphasised the need for a more open-ended research about rainbow families. Partly as a response to such a demand, Swedish sociologist Karin Zetterqvist Nelson has presented a qualitative study comprising fortynine rainbow families in different constellations with one to four parents. Their common denominator was that the parents defined themselves as homosexuals and that they had chosen to live with their children. Their life stories proved to be very diverse, but the overall impression was that it had been easier than most of them had expected to obtain recognition for their unusual family constellations. ${ }^{76}$ Irish-Swedish sociologist Róisin Ryan-Flood has studied discourses on fatherhood and anonymous versus known sperm donors in Ireland and Sweden and found that Swedish lesbian mothers to a much higher degree preferred the donor to be known and wanted different degrees of involvement of the biological fathers, whereas Irish lesbians generally preferred anonymous donors. It seems that discourses on gay parenting and assisted reproductive technology 
vary between countries. For example, Danish law explicitly forbids the storing of identifying data on sperm donors, while Finland, Norway, and Sweden require the donors to be identifiable so that the child can contact its father after its eighteenth birthday. 77

This study aims to supplement the rich discussion about partnership laws and the redefinition of the modern family by situating the creation of the laws in time and space, thereby providing a solid ground for conclusions about gender, sexuality, and the recognition of the same-sex couple in contemporary society. It is a study about political and discursive change in Scandinavia with bearings on the international scene. For in the rapid globalisation process that has taken place since Denmark first introduced a law regulating same-sex relationships, the experience of official recognition of non-heterosexual lifestyles has become a concern not only for Western society but also for all countries and legislatures.

\section{Outline}

Chapter One serves as a chronological overview for the period leading up to the introduction in each Scandinavian country of the law on registered partnership. In addition to that, the failure to introduce such a law in the Danish dependency of the Faroe Islands will be presented, and a comparison will be made with Greenland, where the Danish law was introduced without much debate in 1996. Chapter Two will analyse the internal debate in the Scandinavian gay and lesbian movements until the law was in place. It will demonstrate why the discussion was sometimes heated and how there was an almost unanimous rejection of separate laws for homosexuals - the very model that was subsequently introduced. Lesbian feminist resistance to gay marriage will be presented, as well as the Danish Gay Liberation Front's disdain for this kind of legislation. Chapter Three raises the question of why and when mainstream politicians began taking gay and lesbian demands seriously and also what significance the AIDS crisis had for gay and lesbian rights in general and gay marriage in particular. Chapter Four will discuss the implementation of the partnership laws, as well as their immediate effects on Scandinavian society as a whole. Chapter Five presents a statistical overview of the number of registered partnerships in each country and discusses the ratio of male/female couples and the overall tendencies in each country. Chapter Six will discuss the development from partial to full marital rights, and it will trace the various changes of the registered partnership until it more and more has come to resemble "real" marriage, finally to be converted into gender-neutral marriage laws in Norway and Sweden. A concluding chapter summarises the results.

Since the chronological overview in the first chapter lays out the main features of the process and the following chapters go deeper into the analysis of 
it, some repetitions are unavoidable. I have chosen this thematic plan in order to bring out and highlight the main questions of the book since I believe that a chronological arrangement would have obscured some of the results. 


\section{Chapter One: The road to registered partnership}

The laws on registered partnership were revolutionary in that it was the first time the state recognised individual same-sex couples as legitimate. That is not to say that they lacked legitimacy in a number of other respects before the laws were adopted. Long-term relationships between persons of the same sex were seen and acknowledged as part of social life long before that, and even during periods of pronounced anti-homosexual campaigns, such couples could live and thrive among friends. In 1963, two lesbians who had a central position in Stockholm's lesbian and gay subculture arranged a wedding ceremony. Vivi Astroy, better known as Jerry, and her wife Märta hosted the popular Jerry's Ladies Clubs (Jerrys damklubbar) in the I96os and many lesbians have testified how important that was for them when they were young. When Jerry and Märta decided to get married, they invited some fifty people to Druvan, an old and wellknown restaurant with large banquet halls. Sven, who was a guest, has described how everything was like a "real wedding." Jerry wore a tailcoat and Märta a wedding gown. There were bridesmaids and an altar and candles. A gay man, who had some authority as a priest or a deacon, officiated. Sven remembered it as a very nice occasion, with speeches and gifts and dancing. "But I guess many frowned at it and thought that it was extravagant. It was rather daring for the time." There were others who arranged weddings like that back then, Sven said, also men, but mostly on a smaller scale and among an intimate circle of friends. "They would promise eternal fidelity in front of us witnesses and exchange rings, and then we had dinner."

Sven's story shows that there were gay weddings well before the authorities began pondering whether to recognise them or not. In the circle of friends and in the midst of supportive networks, same-sex couples sought recognition from those who were important to them, and did not yet expect the state to grant them any rights. It also demonstrates how lesbian and gay networks had begun to interlock in the post-war period. Before the war, there were very little contacts between lesbians and gay men in the Scandinavian subcultures. ${ }^{2}$

Recognition by friends and community is one fundamental aspect of marriage (others being the recognition by God through a religious ceremony or by one's family of origin if they come to the wedding) but the recognition by the state is also important. The Scandinavian states were not ready to acknowledge 
the legitimacy of same-sex couples until the late twentieth century. This was preceded by a long process of redefining marriage, in which Scandinavian legislators were more apt to change than in many other parts of the world. British legal historian David Bradley has characterised Scandinavian marriage law reform in the beginning of the twentieth century as different from other West European countries:

From a comparative perspective, the Scandinavian family laws enacted in the period 1909 to 1927 were progressive. In rejecting the concept of Christian marriage to the extent of recognising divorce for incompatibility and confirming sexual equality to the extent of providing women with rights to deferred community property, the new laws in Norway, Sweden, and Denmark differed from those in force in most other West European countries in the early twentieth century. ${ }^{3}$

In all Scandinavian countries, important changes were made in marriage legislation between I9I5 and 1927, giving women more rights and a more equal standing in marriage. ${ }^{4}$ At this time, there was a high level of cooperation concerning family law between the Nordic countries, but it was mainly a question for jurists. In the mid-I950s, however, family law became increasingly politicised, and the politicians did not want to leave it up to legal experts to decide. The Nordic Council recommended that its member countries investigate the prerequisites for a reform of the marriage laws, and in 1956-57 marriage-law commissions were appointed in all the Nordic countries. ${ }^{5}$

The task to reform an institution like marriage was formidable, and the commissioners trod cautiously as they tried to narrow the gap between the old laws and real life. But as the marriage-law commissions slowly proceeded with their work, the world around them began changing. A wave of protest rolled over the world in the I96os, a world that, with TV and faster communications, was rapidly shrinking. The Vietnam War, the U.S. civil rights movement, democracy in universities, sexual liberation, rock music, and protests against formal dress codes - all these became issues shared by young generations all over the world, including Scandinavia. ${ }^{6}$

Though marriage was one of the key institutions of traditional society, the ig6os saw many other forms of living together, including unmarried couples, groups, and openly gay and lesbian couples. This also influenced the ongoing process of marriage reform. When the Danish Ministry of Justice presented a law proposal on marriage and divorce in 1968, the Socialist People's Party (Socialistisk Folkeparti, SF) presented a more radical alternative. Instead of the Government's suggestions, which they deemed too conservative, they wanted an entirely new marriage law that would simplify divorce, establish eighteen years as the lowest age for marriage for both women and men, and abolish the institution of betrothal. According to party leader Poul Dam, there was a need 
for radically new thinking in these matters, and their proposal was meant to open up debate.

The leftist proposal contained even more radical suggestions, such as allowing marriage between siblings and making it possible for steady relations to be "recognised by the authorities" if either one of the persons involved in it so wished. This possibility would also be open for same-sex couples. Finally, it suggested a statute concerning "extended families" (storfamilier), the type of communal living then becoming increasingly popular in Denmark. It would allow the members of such communes to have their group relation "registered by the authorities" and to get help to regulate their internal affairs if there was a conflict. ${ }^{7}$

In Sweden, the Government's Family Law Commission (Familjelagssakkunniga) presented its report in 1972, proposing that the obligatory marriage ceremony should be replaced by a simple act of registration. Divorce should be facilitated and a number of restrictions to marriage abolished, but there were no provisions for same-sex couples or alternative lifestyles in the proposal. ${ }^{8}$ The Swedish National Union for Sexual Equality, the RFSL (Riksforreningen for Sexuellt Likaberättigande), severely criticised the commission for that, and wrote letters to all political parties and all Government agencies involved in the legislative process, complaining about the lack of initiatives to help and support same-sex couples. ${ }^{9}$ In Parliament, the Left Communist Party (Vänsterpartiet Kommunisterna, VPK) presented a counterproposal to that of the Family Law committee. It was more radical than that of its Danish sister party five years earlier in that it suggested that marriage as an institution be abolished and replaced by "registered cohabitation" (registrerad samlernad). This simplified form for regulated bonding should be open also to "sexual deviants" - a wording that the Standing Law Committee later criticized as too vague. ${ }^{10}$ When it came to extended families, the Swedish motion was more cautious, saying that it was too early to evaluate their significance and to legislate about them. The Swedish Parliament turned down VPK's proposal but issued a statement that homosexual cohabitation was a life form fully acceptable to society. Since then, this statement issued by the Swedish Parliament was quoted by the RFSL in all possible situations where gay and lesbian rights were discussed. ${ }^{\text {II }}$ This proposal marked the beginning of VPK's commitment to gay and lesbian rights, and especially that of its MP Jörn Svensson, who dedicated himself to gay and lesbian rights issues. Svensson was considered one of VPK's most important ideological theorists, and one who sharply criticised the new pragmatism of the party. For him, the question of gay and lesbian rights was fully compatible with a firm commitment to its Marxist foundations. ${ }^{\text {I2 }}$ 


\section{Gay and lesbian rights in the 1970 s}

The Stonewall rebellion in 1969 was an important source of inspiration for the new generation of gay and lesbian activists in Scandinavia. News about the riots on Christopher Street in New York spread quickly through the gay media, and even if they were the result, rather than the cause, of an international radicalisation of the demands for sexual equality, they were quickly adopted as a symbol for gay rights. ${ }^{\mathrm{I} 3}$ Already in 1970, the Danish organisation discussed whether to celebrate Christopher Street Day, but instead they chose to make their presence known at the May Day celebrations of the national trade unions' movement. The next year, however, The Society of 1948 celebrated Christopher Street Day Men's on June 25 by organising a party in Falledparken park in Copenhagen, thereby marking their adherence to the international gay and lesbian movement rather than to the national left. It was on that occasion, in I971, that the Danish Gay Men's Liberation Front (Bøssernes Befrielses Front, or BBF) was created and has ever since functioned as a radical wing of the Danish gay movement. With its rather anarchistic ideology, however, it never aligned itself with the established left-wing parties. ${ }^{\text {I4 }}$

The homophile movements in Denmark, Norway, and Sweden had stagnated by the end of the ig6os, and a new generation wanted to address the inequalities in legislation and society. Inspired by new currents in the political debate, the highest priority of the new generation of activists was to fight the higher age of consent for same-sex relations in Denmark and Sweden, and the general ban on sex between men in Norway, but there was insufficient support for the change in most Scandinavian parliaments. ${ }^{15} \mathrm{~A}$ proposal to lower the age of consent to fifteen in Sweden was rejected by the Riksdag in I972. When it had been time to be voted on, the younger members of the RFSL had staged a hunger strike - a rather new kind of action in Sweden, clearly inspired by the civil rights movement in the United States. In Norway, the activists of The Norwegian Society of 1948 (Det Norske Forbund av 1948, or DNF' 48 ) lobbied against the prohibition of male homosexuality but were cautious, fearing the new law might include a higher age of consent for both women and men. Following a campaign from DNF' 48 , Norway decriminalised same-sex sexuality in 1972 and also set an equal age of consent for homosexual and heterosexual relations. ${ }^{16}$ In Denmark, the age of consent was made equal in 1976 and in Sweden in I978. Similar reforms occurred in Iceland in 1992 and Finland in 1999. ${ }^{17}$

While the policy of the gay and lesbian movements in Denmark and Sweden was to demand marriage for homosexuals, the Norwegian movement chose another way. After the decriminalisation of male homosexuality in 1972, The Norwegian Society of 1948 had to decide on its future priorities, and in March I973 its chair Kim Friele sent out an invitation to the leaders of the gay and lesbian movements in Scandinavia and the Netherlands to a discussion in Oslo. At the meeting, it turned out that the Swedes wanted some kind of gay marriage, 


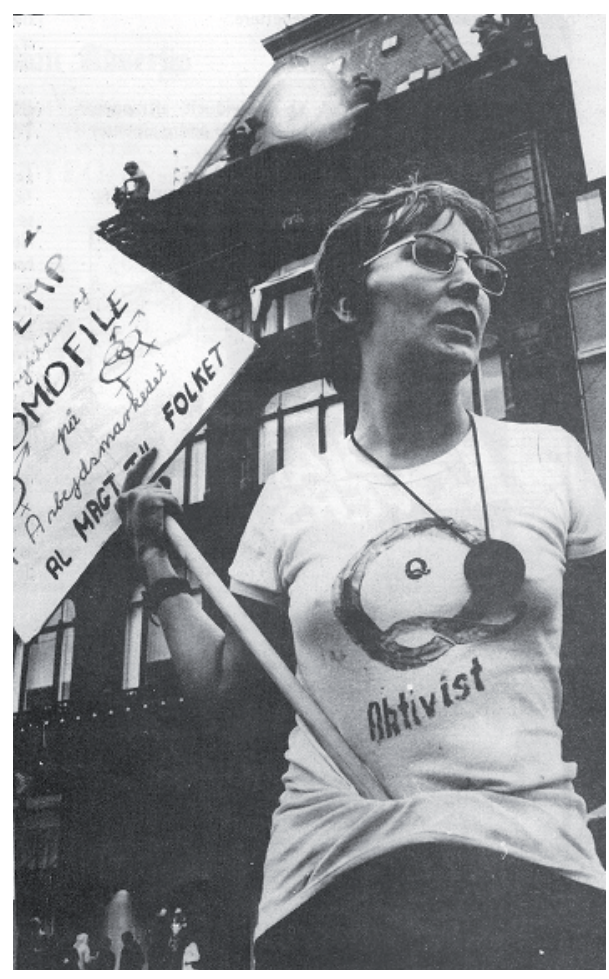

The first Christopher Street Day celebrations in Copenhagen occurred in 1971. Source: PAN-bladet, Copenhagen, no. 4 (1971).

the Danes concentrated on practical issues in connection with housing, inheritance, pensions, and adoption, and the Norwegian and Dutch delegations said no to traditional marriage and yes to other forms of legal regulation of differentsex, same-sex, and multi-partner relations. ${ }^{18}$

After the international conference, the annual meeting of the $\mathrm{DNF}^{\prime} 48$ decided that it should reject the idea of homosexual marriages because it would grant privileges to couples at the expense of those who could not or did not want to live in steady relations, a decision that would determine the Norwegian movement's policy on the matter for almost two decades.

As a result of this anti-marriage policy, other questions dominated the movement. In the I970s the Norwegian movement split in two following fierce ideological battles. The history of the lesbian and gay movements in Norway has been profoundly marked by this conflict, something which requires a somewhat detailed account of it.

Politically, most of the Norwegian activists sympathised with either the Socialist Left Party (Sosialistisk Venstreparti) or with the Maoist Marxist-Leninist Workers' Communist Party (Arbeidernes Kommunistparti [marxist-leninistene], AKP $[\mathrm{m}-1])$. For gays and lesbians who sympathised with AKP it was a great disappointment when the draft of a "Declaration on homosexuality" (Fråsegn om homofili) from the party's Central Committee became known in 1975 . The 
declaration claimed that "homosexuality is essentially a sexual deviance with its roots in societal and social conditions," and that "it is not the business of communists to promote homosexuality or propagate that homosexuality is 'desirable'." Moreover, it supported wholeheartedly the anti-homosexual politics in China and Albania. It was a document meant for internal discussion, but it leaked out and caused sharp reactions from other leftist activists for lesbian and gay rights. ${ }^{19}$ For those lesbian and gay activists who were party members it was a dilemma since they were unable to criticise the party publicly. Some of them repudiated parts of the document, some chose not to comment on it outside the party discussions. The conflict between AKP and the national board of DNF ' 48 grew when two lesbians looking for an apartment were refused an advertisement in AKP's publication Klassekampen with the explanation that "we cannot, as Marxist-Leninists, based on Marxism-Leninism and centuries of experience, regard homosexuality as a desirable condition." ${ }_{20}$ In October 1975 an issue of DNF '48's publication Fritt Fram was seized by the national board of DNF' 48 and the whole editorial board was dismissed because the national board claimed that the issue contained "unsigned Marxist-Leninist material." ${ }^{21}$ The methods were deemed by many as too harsh and undemocratic, since the DNF' 48 leadership refused to enter into any discussions with the dissenters. ${ }^{22}$ In May 1976 the opposition left the DNF' 48 in order to found a new organisation, the "Working Groups for Homosexual Liberation," or AHF (Arbeidsgrupper for Homofil Frigjøring). The Marxist-Leninists, who for political reasons regarded the Socialist Left Party as their main "tactical enemy," initially opposed the founding of the new organisation and most of them remained within the DNF' 48 . Gradually, however, Marxist-Leninists joined the AHF too - often as "double members," keeping their membership in $\mathrm{DNF}^{\prime} 48$ - with the aim to take over the organisation. Their method was to obstruct the meetings with endless ideological discussions and sophisticated Marxist-Leninist arguments. By early I978, many AHF members who sympathised with the Socialist Left Party had tired of the polarised atmosphere and endless debates and they abandoned the AHF, which thus became completely dominated by Marxist-Leninsts. The Socialist Left Party sympathisers went on to found a new organisation, the "Group Lambda" (Gruppe Lambda), but most activists were now disillusioned after having lost in two bitter conflicts, and the new group remained insignificant. ${ }^{23}$

Meanwhile, opposition against the national board continued to grow within the DNF' 48 , especially in Bergen, where both AKP supporters and Socialist Left Party sympathisers had remained inside the national organisation, and only a few had joined the Oslo-based AHF. In November 1978, the DNF ' 48 leadership decided to exclude all "double members," those who were also members of the AHF. In Bergen most board members were excluded or suspended and the Bergen branch of DNF' 48 was put under direct administration from Oslo. During the following months, however, most Bergen activists left the 
DNF' 48 and founded "The Gay Movement of Bergen," or HBB (Homofil Bevegelse i Bergen). Similar situations occurred in Stavanger and Tromsø, where the local DNF' 48 branches were dissolved and replaced by independent organisations. In the autumn of 1979, these new groups, together with AHF and Group Lambda founded the FHO, The Joint Council for Homosexual Organisations in Norway (Fellesrädet for Homofile Organisasjoner i Norge). For the next decade, this loose network of local organisations and the DNF' 48 both worked for roughly the same political goals, first in a situation of rivalry and competition, but as the political differences gradually lessened, the two national organisations began cooperating on many issues. ${ }^{24}$

Neither of the two organisations worked for gay marriage or registered partnership. Instead, the main issue for both during this period was the work for a law against discrimination on grounds of sexual orientation. Their efforts were successful, and in 198I Norway became the first country in the world to include such a statute in its Criminal Code. ${ }^{25}$

In Finland, organised homosexuality came later than in Denmark, Sweden, and Norway. In this East Nordic country, both male and female homosexuality were outlawed until I971, and the law was enforced rigorously. In the I96os, an average of fifty men and one woman were convicted each year for same-sex sexual acts between adults. When homosexuality was finally decriminalised, a higher age of consent was imposed, as well as a law prohibiting "encouragement of homosexuality." Finnish society in the I970s was thus very far from discussing gay marriage, and a number of articles in Finnish media highlighted the plight of gays and lesbians who moved to Sweden as "sexual refugees." ${ }^{26}$ From the early I970s there were two major gay and lesbian organisations in Finland: the Discussion Club Psyche (Keskusteluseura Psyke / Diskussionsklubben Psyke, founded in 1968), which became more of a social club, and was spread all over the country, and Helsinki-based "Sexual Equality" (Seksuaalinen Tasavertaisuus / Sexuellt Likaberättigande, SETA, founded in 1974). SETA was a political group that was founded by radical members of the Psyche, when they saw that they remained a minority within the older organisation. The two organisations merged in 1988 as SETA took over Psyche's local chapters. In the homophobic climate of Finland in the I970s, the priority of SETA was to combat discrimination and prejudice. The Finnish lesbians became more radical in the r980s and did not give priority to a partnership law, which was seen partly as something utopian (given the social climate in Finland) and partly as something undesirable, since it reproduced patriarchal structures. ${ }^{27}$

In Iceland, a gay and lesbian group was first founded in 1978 , and, following the Danish example, it was named after the year it was founded. During its first years of existence The Society of '78 (Samtökin '78) gave priority to social work in order to help its members survive in the homophobic climate. Oppression was felt in language itself, and the approved word "kynvillingar" for ho- 
mosexuals was seen as an insult by the lesbian and gay activists, since it means "sexual erratic" and has connotations to "trúvillingar," heretics. In March I978, the National Radio refused to let Samtökin ' 78 publish an advertisement about a meeting, using the words "lesbíur" and "hommar," which were their preferred words for "lesbians" and "gays." This sparked a prolonged fight for their right to choose their own words to describe themselves. In April 1978 they wrote to the official Icelandic Language Commission (Islensk málnefnd) and asked for better words for all things relating to homosexuality. They received a rather reserved reply, saying that the commission had discussed their request, but that it could not come up with any recommendations. ${ }^{28}$ With such attitudes, a small population, and tight family ties, Iceland was known in gay circles in the I980 to be the most homophobic of the Nordic countries, and many gay and lesbian Icelanders chose exile. ${ }^{29}$

Gay and lesbian movements in Scandinavia have been compared to strong and well-structured trade unions, and it is true that they all work in a reformist rather than a revolutionary tradition. Symptomatically, ideological shifts in the struggle for gay and lesbian rights, like the radicalisation after Stonewall, or the impact of queer activism, generally took place within the established movements..$^{\circ}$ The exception to that rule is a period of lesbian separatism in the I980s, especially in Finland, Iceland, and Sweden. As so often, lesbian feminists were split between the women's movements, which many times were insensitive to lesbian demands, and male-dominated gay movements. But the degree of influence that could be exerted by women in the national gay and lesbian associations varied greatly over time and also among the different Nordic countries. ${ }^{3 \mathrm{~T}}$

The main arguments put forth by many lesbian activists were founded on the criticism of marriage as the cornerstone of patriarchy. Since second-wave feminists in the I970s developed theories on the subordination of women in patriarchal society, the question of marriage was not just any political issue, but one of the core questions for the feminist struggle. Thus it is perhaps no wonder that tensions between women and men in the gay and lesbian movements grew in the I970s, which were characterised by an ideological conflict between socialist and liberal forces and between male and female interests within the movements. A new generation of radicalised gay men approached gay liberation as a question of openness and human rights, and in this context the recognition of same-sex relationships - as well as polyamorous relationships - was high up on the agenda. The new generation of lesbian feminists, on the other hand, developed a woman-identified lesbian separatist ideology, in which the struggle against marriage as an institution was one of its most important points. Scandinavian lesbians found new ways to create networks in the I970s and I980s, and they staged a number of cultural and political protests. Among them, their opposition to the exploitation in the porn industry provoked angry reactions from 
the men in the movement, who sometimes accused them of being sex-negative puritans. ${ }^{32}$

\section{The AIDS crisis}

There were big differences in the ways that the gay and lesbian movements and the governments in the different Nordic countries handled the AIDS crisis. The Danish gay and lesbian movement declined to recommend that its members stop donating blood, for fear of further stigmatising gay men. ${ }^{33}$ The Norwegian and Swedish movements, however, asked men who had sex with men to stop giving blood early in I983, well before their respective governments had developed any standpoint on blood donations from various risk groups. ${ }^{34}$

In Sweden, the AIDS question was highly politicised. At the outbreak of the epidemic, the Government created an ad-hoc AIDS Delegation (Aidsdelegationen), directly under the Minister of Social Affairs. The Minister in the I980s was Gertrud Sigurdsen, who took a personal interest in the question, and the differences between the Government and the gay activists soon grew. It was particularly the RFSL's insistence that unprotected oral sex was to be considered safer sex, and its reluctance to recommend testing for its members that caused conflicts and made Sigurdsen regard them as irresponsible. ${ }^{35}$ On the other hand, the coercive methods adopted by the Swedish Government made the RFSL representatives leave the AIDS Delegation. Sigurdsen's harsh AIDS politics also led to tensions between the Ministry of Social Affairs and the National Board of Health and Social Affairs. In 1985 Barbro Westerholm, who was Director General for the National Board of Health and Social Affairs (Socialstyrelsen), resigned because of difficulties cooperating with the Minister.

In Denmark, the situation was the reverse. Two Ministers of Health in a row, Torben Lund and Yvonne Herløv Andersen, were gay and lesbian themselves, and consequently listened carefully to the demands of lesbian and gay activists. The Director General of the National Health Board did not share their positive view of gay activism, and was forced to resign in 1995, later accusing both Ministers of giving the National Union for Gays and Lesbians "an extraordinary positive treatment. ${ }^{6}{ }^{6}$ Danish-Swedish historian of medicine Signild Vallgårda has argued that the dramatic difference in Danish and Swedish AIDS politics is best explained as a result of path dependency and different emphasis in the focus of the AIDS discourse. In Denmark, AIDS was defined as predominantly a problem for men who had sex with men, and the difficulties in reaching that group with information was highlighted. Since attitudes to homosexuality were liberal, this resulted in liberal AIDS politics, and much energy was invested in reaching out to men who had sex with men. In Sweden, on the other hand, AIDS was defined as a problem concerning various risk groups, and in a militant language the necessity of preventing the disease from spreading from 
these groups was underlined. In particular, intravenous drug users were identified as potentially "dangerous" and irresponsible. And since there was a tradition of coercive means in dealing with drug abuse in Sweden, this was also the way in which AIDS was dealt with. ${ }^{37}$

As for the other Nordic countries, HIV prevention work was carried out on a lower level in the bureaucracy, which allowed for a relatively trustful cooperation between gay activists and the civil servants in the National Health Boards. While Sweden based its AIDS policy on control and coercion and Denmark adopted a policy characterised by trust and information, Norway chose a middle way. A telling example is that when Sweden and Norway added HIV infection to the list of contagious diseases covered by the law, Denmark abolished its corresponding law, arguing that it had no effect on the prevention of disease. And whereas Swedish authorities outlawed gay saunas, they remained open in Denmark and Norway. The relations between the Norwegian health authorities and the lesbian and gay movements was trustful, and the authorities seldom failed to listen to the gay and lesbian HIV-prevention agency. ${ }^{8}$ Kjell Erik Øie was the leader of Norwegian DNF' 48 from I987 to I99I. In an interview in 2004 he explained why he thought the DNF' 48 had better cooperation with the authorities than their Swedish counterparts. The gay and lesbian movement in Norway, he said, could have a serious dialogue with the health authorities about reducing the number of sex partners. "We had a reputation of being - contrary to you in Sweden - very responsible. That's the reason I think they didn't shut down our sauna clubs." 39

In Finland, SETA had had preliminary contacts with the National Medical Board (Lä̈̈kintöhallitus / Medicinalstyrelsen) and urged them to issue advice and regulations concerning AIDS before the first cases were even reported, but to no effect. Jorma Hentilä was chair of SETA from I983 to I99I, and he had to begin his office with coping with the AIDS crisis. When the first two cases were reported in Finland in 1983, information about them was leaked to the tabloids and a national panic quickly grew, but there was no initiative from the Government. "The National Medical Board gave no advice or anything. No guidelines whatsoever," Hentilä complained. Instead, SETA's office was turned into a medical advice centre. In the summer of 1983 its small office was crowded with anxious people. "We offered counselling," Hentilä said. "There was a doctor and a psychologist ... We made an agreement with The Institute for Popular Health (Kansanterveyslaitos / Folkhälsoinstitutet) that they would analyse our tests. And we agreed on anonymity. That was important." The Finnish AIDS activists managed to avoid the kind of coercive legislation that they saw in Sweden by building up a close cooperation with health agencies at an early stage. ${ }^{40}$ Finnish sociologist Kati Mustola has described these years as transformative for SETA and the established lesbian and gay movement: "Through its AIDS activism, SETA became an important social actor, and the organization's image in 
the eyes of both officials and the general public changed from that of a club for freaks to a responsible civic organization among other civic organizations," she wrote in a 2007 study. ${ }^{4 \mathrm{I}}$

The effect of AIDS in terms of rendering more visible the gays and lesbians in society is perhaps even more striking in a small country like Iceland. In the Icelandic press, as elsewhere in Scandinavia, the first reports about AIDS described it as a foreign "gay plague," but as soon as the first domestic cases became known, the tone in the media changed. Gay men were now depicted as a vulnerable group in need of society's help. In a small society with tight family bonds like the Icelandic, every case meant that a large number of friends and relatives became directly affected by the disease. The first battle to be fought, however, was the predictable and quintessentially Icelandic one of what to call the epidemic. The strongly negative term eydni, which means "devastation," was proposed and rejected. Finally the word alnami, which means something like "hypersensitivity," was chosen. The Icelandic AIDS epidemic has been limited to 60 cases and 37 deaths out of a population of 320,000 (in 2008), but each AIDS patient has a wide network of friends and family who are affected. All in all, the AIDS epidemic led to radically more visibility and a greater acceptance of homosexuality in Iceland..$^{2}$

In Greenland and the Faroe Islands, the AIDS epidemic has displayed patterns very different from the rest of Scandinavia. In the absence of a local gay subculture and health care facilities for gay men, the recorded cases consist almost exclusively of heterosexually transmitted infections. Moreover, the tradition of gay exodus has resulted in a situation where HIV-positive gay men from these areas most often have contracted the virus in metropolitan Denmark or elsewhere. In the I980s, for instance, a gay man living on the smallest Faroese island of Mykines, with less than twenty inhabitants, suddenly became ill and moved to Denmark where he could get better care. When he died, he willed his house to the Danish AIDS Fund (AIDS-fondet), but he never came out to the local community. ${ }^{43}$ In Greenland, when the law on registered partnership was first discussed in 1994, thirty-year-old Tom Semionsen appeared in the national press and revealed that he was gay and HIV-positive. Like many other gay Greenlanders, he had lived in Copenhagen to be able to experience a gay subculture, and it was there that he had contracted the virus. Since then, he moved back to Greenland, where he could be close to his family and to Greenlandic nature, even though he was aware that he might get better care in Copenhagen. After Semionsen's coming out, it was not until 2003 that more gay or lesbian Greenlanders came out in public. ${ }^{44}$

All over Scandinavia, the AIDS crisis brought with it a new need for a dialogue between the gay and lesbian movement and the authorities. And even if the contacts at a central level in some cases were hostile, the contacts at a local level could lead to new insights and a fruitful dialogue. All over Scandinavia, lo- 
cal politicians met for the first time with gay and lesbian activists and discussed AIDS-preventive measures, offering financial support and cooperation when planning the information campaigns. This way, local politicians were confronted with a hitherto invisible section of their town, and gay and lesbian activists got access to a political arena they had previously been barred from. The wish to control gay men's sexual behaviour necessarily brought forth a new understanding from the majority culture, and homosexuality as such became more visible in all Scandinavian countries.

\section{Government commissions in the I980s}

As we have seen, the increased official acceptance of homosexuality in Scandinavia began well before AIDS, and, indeed, well before the Stonewall rebellion. The discussions at parliamentary level about legally regulating same-sex relations were initiated by a proposal to Parliament in Denmark in 1968, followed by a similar proposal in Sweden in I973. Following the success when the Swedish Parliament declared that homosexuality was a fully acceptable life form, the small Left Communist Party (VPK) continued to promote gay rights in the Riksdag. Following motions from Left, Social Democratic, and Liberal MPs, the Government appointed a commission in 1978 with the task to "compile and give an account of available scientific documentation about homosexuality" and to "propose the necessary means to remove any remaining discrimination of homosexuals." 45

The so-called Homo Commission (Homosexutredningen) worked for six years, and it was, to date, the largest investigation of homosexual life in Scandinavia. The proposals in its 1984 report were rather far-reaching, and proposed I) constitutional amendments to protect homosexuals from discrimination and defamation in general terms; 2) an amendment to the criminal code to make discrimination and defamation of homosexuals punishable; 3 ) refugee status for persecuted homosexual foreigners; and 4) a new law regulating same-sex relationships..$^{4}$ The proposal was to let same-sex couples benefit from the same legal protection that different-sex couples already had according to the "Unmarried cohabiting couples' mutual home act" (Lagen om ogifta samboendes gemensamma hem), in force since 1973. It took considerable time for the Government to issue a law proposal. When it was finally presented in 1987 it was rather bleak. Out of the four main proposals set down by the Homo Commission in 1984, only two resulted in legislation. There were no amendments to the Constitution and there were no changes in the law giving homosexual refugees the right to asylum. But the criminal code was amended to include a prohibition against discrimination and defamation of homosexuals, and a homosexual cohabitation law regulated the rights of the persons involved in same-sex relations in case of separa- 
tion. The Law on Homosexual Cohabitation was probably the first law that any country passed concerning homosexual relations. ${ }^{47}$

In 1982 the Danish Society of 1948 changed its name to The National Union for Gays and Lesbians (Landsforeningen for Bøsser og Lesbiske, LBL). The following year it invited politicians from the four gay-friendly parties in the Folketing to a debate in Århus on gay and lesbian rights..$^{8}$ During the meeting, it occurred to LBL's chairman Henning Jørgensen that there was a consensus among the four representatives on a number of pro-gay measures. Furthermore, he realised that these four parties together had a majority in the Folketing, against the conservative minority Government. He quickly asked them if they could go back to their parties and get them to present a bill to the Parliament, demanding that a commission be appointed to investigate the situation for homosexuals in society and propose measures to remove discrimination. After all they had agreed on during the debate, they could not really say no, and gay activist Bent Hansen remembers how he and other LBL activists hurried to send out a press release about the historic pledge, thus making sure that the politicians could not back away from their promise when they came back to Copenhagen. ${ }^{49}$

So there was no way back for the four parties, and in March 1983 a majority in the Folketing carried the four-party proposal to appoint a commission to "throw light on homosexuals' situation in society." Its instructions were to propose measures to remove remaining discrimination within all sectors of society, "including proposals for regulating steady relationships." ${ }^{\circ}$ Since the conservative minority Government was against the commission, but was forced by the Parliament's majority to appoint it, they showed little interest in what it was doing.

The work in the commission dragged on, and instead of waiting for its report, the LBL persuaded their political friends in Parliament to present concrete proposals to be voted on. Thus, already in 1986, the Folketing decided to grant the same inheritance tax to same-sex couples as to married couples, and in I987 it voted on an amendment to the statute against discrimination, so that it explicitly covered sexual orientation. ${ }^{5 \mathrm{I}}$ This initiative and others put pressure on the commission, and finally it presented its report in 1988, which, however, did not endorse the idea of registered partnership. Its chairman, Poul Dam, who in I968 had presented the Socialist People's Party's radical marriage law proposal, now did not favour the idea of registered partnership. He used his casting vote to prevent the commission from including it in its proposal. The four homosexual representatives wrote a differing opinion, and again the initiative for lesbian and gay reforms belonged to the Parliament..$^{52}$

The Icelandic Homo Commission came later than in Sweden and Denmark, but when politics began to change, they changed fast. In a small society like Iceland it was not difficult for the lesbian and gay movement to establish contacts with members of the Alpingi, provided they were prepared to listen. Also, the 
strong feminist movement had paved the way for changes concerning homosexuality. The 1992 initiative to appoint a Homo Commission in Iceland came from the Women's List, which had a stable representation in Parliament. It did not seem that any anti-homosexual sentiment was represented in the Alpin$g i$ at this point in history. The multi-party proposal initiated by the Women's List went through without much discussion, and an Expert Commission was formed with two representatives from Samtökin '78. It presented its report in 1994, with three main proposals: I) Prejudice should be fought by disseminating positive information about homosexuality in the Icelandic educational system, and by economic support to the lesbian and gay movement. 2) Discrimination and harassment of homosexuals should be outlawed.3) A law on registered partnership, modelled after the ones existing in Denmark, Norway, and Sweden, should be adopted. A dissenting minority, consisting of the two representatives from Samtökin '78, wanted to go one step further and introduce legislation that would allow same-sex couples to enjoy a legal status fully comparable to that of different-sex couples. ${ }^{53}$ Their demands for a law that would include adoption rights and joint custody over children was different from the pragmatic attitude of the Danish, Norwegian, and Swedish movements, which accepted the restrictions in order to get the laws passed.

\section{Breakthrough in Denmark}

In the Danish elections of I987, the Left Socialist Party (Venstresocialisterne, VS) lost their five seats in the Folketing, but the three remaining "gay-friendly" parties could still muster a majority over the conservative minority Government. In January I988, even before the commission had presented its report, they proposed a registered partnership for same-sex couples. The bill was based on the detailed proposal that LBL had drawn up in I98I, and its first article read: "Two persons of the same sex can have their partnership registered." The rest of the short law referred to the existing marriage law, and then enumerated three exceptions compared to marriage: I) registered partnership could only be granted if at least one of the two persons was a citizen and lived permanently in Denmark, 2) the Adoption Act was not applicable, and 3 ) the new law did not interfere with the parts of the marriage law that regulated church weddings. Like most new Danish laws, it would not automatically be in force in the Faroe Islands or Greenland but could be introduced there by means of a Royal Decree after an initiative of the local Parliament. This provision gives the local parliaments in these autonomous Danish areas the possibility of accepting or rejecting Danish laws, and, as we will see, they went separate ways regarding the law on registered partnership. ${ }^{54}$

The law proposal had a comfortable majority in the Folketing, with the support of the Social Democrats, the social-liberal Radical Left Party, and the So- 
cialist People's Party. But then the Prime Minister dissolved Parliament - on a whole other issue - and called for new elections. During the electoral campaign, the small Christian People's Party (Kristeligt Folkeparti) vowed to stop the proposed partnership law. Its attempt to attract conservative votes by opposing the law inspired a newspaper to order an opinion poll. The result was a surprise to both those who were in favour of the law and those who worked against it, since it showed that $5^{8}$ percent of Danes supported the idea of a law on registered partnership, whereas only 20 or 25 percent were clearly against it. This result strengthened those in favour of the law and the Christian People's Party got only 2 percent of the votes and four seats in Parliament. After the elections, the Radical Left Party entered a coalition government with the Conservatives and the right-of-centre liberal Left Party (Venstre). ${ }^{55}$ Now they were bound to the Government's politics and its ministers could not vote for a law on registered partnership even if they wanted to. However, there seemed to be enough votes in Parliament to get the law through, as the Social Democrats had decided to support it. ${ }^{6}$

On May 26, when the law was to be voted on in the Folketing, Social Democratic MP Pia Gjellerup had reserved seats in the gallery for the LBL activists, and they were told how to act. "You have to behave in such a place - you can't sit there and shout and cheer, you know," gay activist Bent Hansen explained in an interview in 2005. "So we had agreed with everybody who showed up that when the proposal was carried - and we were 99.9 percent sure it would - we would rise and bow to the Folketing and walk out. A silent but remarkable reverence to them all." 57 Moreover, the LBL gave a rose and a printed card showing the painting "Summer night on Skagen Beach" by Peder Severin Krøyer to all the members of the Folketing to thank them for the law. Though not everybody had voted for it, the LBL wanted everybody to have a memory of the day. When the law was voted on after a rather fierce debate, it was carried by $7 \mathrm{I}$ votes against 47 and 5 abstentions, a $5^{8}$ percent majority. When the voting was over, the LBL people in the galleries silently rose and bowed, and left the building. And in the afternoon everybody was invited to the LBL Centre in Knabrostræde. It was a beautiful summer day, and the owner of the Centre's restaurant served everyone free beer from the tap. "It was wonderful," Bent Hansen remembers. "That day you thought it was worth the effort of all these years. It was a tremendous success." ${ }^{8} 8$

The Danish success had come quickly and smoothly, and it sent shock waves to gays and lesbians, as well as to their foes, all over the world. When the law became effective, on I October 1989, the world press was there, and the first gay couple in the world to be registered in accordance with national legislation was Axel Axgil, the founder of The Society of 1948 and his longtime companion Eigil Axgil. The LBL had arranged the ceremony and the ensuing party and made sure it looked like a lavish wedding, with horse-drawn carriages and all 


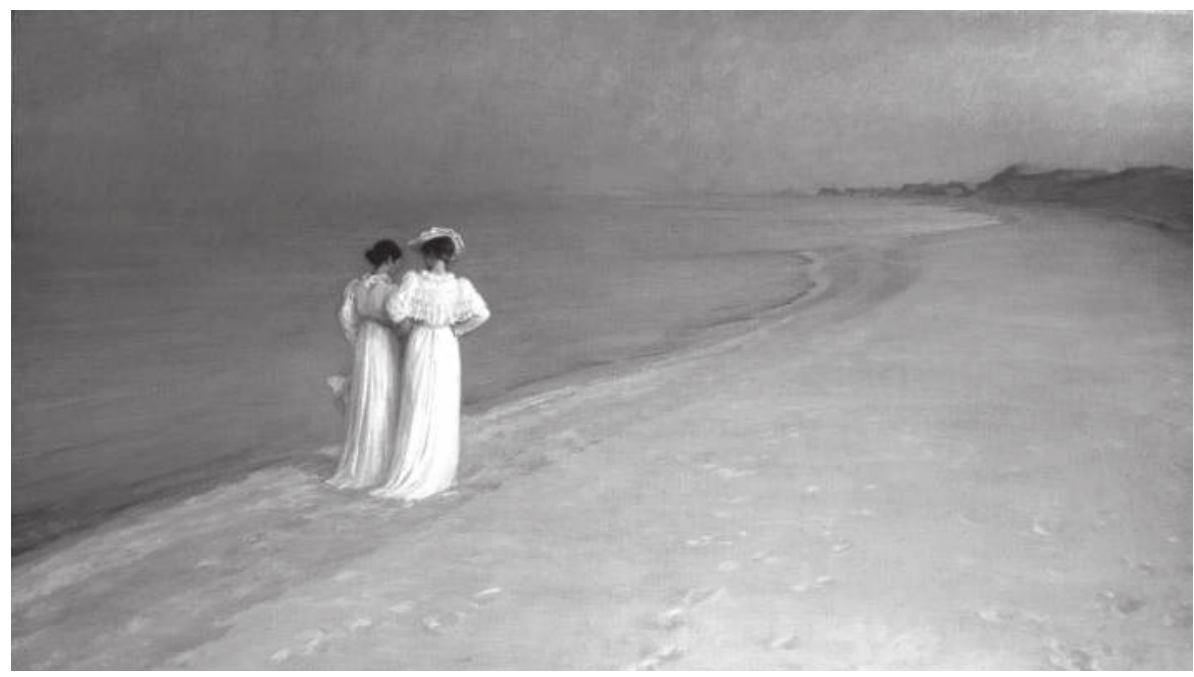

The Danish LBL wanted to give all members of the Folketing a memory of the day, even those who had voted against the partnership law. When the MPs left the building, they got a rose and a card with this painting. Peder Severin Krøyer, "Summer night on Skagen Beach" (1893). Courtesy Skagen Museum.

the usual matrimonial festivity. There were eleven male couples who were registered that day in Copenhagen, but no female couples, a fact that will be discussed in Chapter Two. ${ }^{59}$

\section{Domino effect in Central Scandinavia}

Before 1989, there was no consensus in the Norwegian and Swedish gay and lesbian movements regarding the need for a law on registered partnership. In Norway there was an outspoken resistance to such a law, ideologically founded in the conviction that the legal regulation of same-sex relations must not give privilege to couples at the expense of those who live outside steady relationships. ${ }^{60}$

However, the spark produced by the adoption of a partnership law in Denmark coincided with a generational shift in the Norwegian gay and lesbian movement. Karen-Christine Friele, who had been the chair of DNF ' 48 since 1966, and its employed secretary general since 1970, was fiercely opposed to the politics of the new activist generation. With the advent of AIDS, the conditions for gay and lesbian politics changed profoundly, and in her furious autobiography from 1990, Friele argued that the AIDS prevention work was carried out at the expense of traditional information and sex education, and lesbian interests were altogether neglected. "Instead of meeting the needs and interests of lesbians, elected lesbians flew to 'safer-sex' meetings and learned how to put on condoms!"'ri 
Friele also accused the movement of using the AIDS crisis to get rid of an older generation of activists, a trend that she said was not exclusively Norwegian. "The threat of AIDS demanded 'modern' homo politics carried out by young colleagues," she wrote. "In country after country, old oppositional activists were dismissed. Hundred-thousand-crown computers, white desks, and sets of green plants witnessed to the truth of the old saying, 'Nothing is so bad that it isn't good for something."' ${ }^{6}$ What Friele saw, and reacted so violently against, was the professionalisation of the gay and lesbian movement in the wake of the AIDS crisis. Money was pumped into the national movements, which suddenly could afford paid staff with all that that involved of workplace regulations, salary negotiations, and stability of the organisations. The conflicts between unpaid activists and paid staff of the organisations sometimes became acute, and often involved strong feelings of frustration from many activists who thought that the movement sold out its ideals and became too dependent on public funds.

The new chair of The Norwegian Society of 1948, Kjell Erik Øie, was in favour of a partnership law and there was an ongoing conflict between his working group for partnership law and Friele. "The first time Gro Lindstad, who was vice chair at the time, and I decided that we wanted to challenge DNF's standpoint, that we mustn't work for marriage, Kim mobilised against us and there was a lot of infighting, and it all ended with a decision that we should work for all who lived together for different reasons." ${ }^{3}$ Friele's main argument that the law favoured couples over individuals was difficult to sustain in the presence of the enthusiasm of the younger activists, and finally she stuck to the argument that it was a second-class marriage, since adoption and insemination were not open to same-sex couples.According to Kjell Erik Øie, Friele could not specify what it was in the marriage law that she did not want and that she thought had discriminatory effects. "It is one thing to be ideologically against something, but when you have to determine what it means in practice, it becomes more difficult." From then on, says Øie, Friele concentrated on the argument that DNF ' 48 did not demand the right of adoption when they argued for the law. ${ }^{64}$

Under Øie's leadership, the Norwegian gay and lesbian movement set up a working group to lobby for a law on registered partnership similar to the Danish law. They were remarkably successful in their lobbying efforts, targeting key persons and members of Parliament whom they thought were possible to reach with their arguments. "There was no reason to waste our energy on the Christian People's Party. There were some in the Progress Party [worth talking to], but the rest we tried to influence," Øie explained. According to Socialist MP Kristin Halvorsen, they gained a reputation of having good answers to all questions and being reliable when it came to facts. ${ }^{65}$ After a long debate, the Norwegian law was finally passed by the Storting at 9 p.m. on 29 March 1993, with 58 votes in favour and 40 against. As a sharp contrast to the silent bow of the activists in 
the Danish Parliament four years earlier, there were wild cheers from the gallery, and the Speaker had to silence the crowd twice. ${ }^{66}$

The law took effect on August I, but it took four days to issue marriage licences, and on August 6 a big wedding celebration was staged by the National Union for Gay and Lesbian Liberation, the LLH, as the joint gay and lesbian movement in Norway was now called. The partying and the press coverage resembled that in Denmark four years earlier, with one important difference. Whereas only male couples had registered on the first historic day in Denmark, there was now a mixture of gay and lesbian couples. Indeed, one of the first couples to register in Norway was Kim Friele and her companion of many years, Wenche Lowzow. ${ }^{67}$ The official celebration was in Oslo on August 6, but two gay men, who preferred to remain anonymous, registered in Skien the day before. This was considered by some activists as somewhat disloyal, or as an attempt to become historic and steal the moment from those who had actively worked for the law. ${ }^{68}$

Nobody had really expected Norway to beat Sweden in the "partnership race," considering the preparatory work that had already been done in Sweden and the strong Christian conservative lobby in Norway. But whereas the process seemed to stagnate in Sweden, the Norwegian lobbyists managed to influence people surprisingly quickly and thus created the necessary majority for the law. This can evidently be attributed to several factors, most important, perhaps, the readiness of the political parties to listen to gay and lesbian demands for equality, and the day-to-day balance in coalition politics.

In Sweden, the official stance of the gay and lesbian movement had been to reject the thought of a separate registration for same-sex couples, but all such reservations were swept away when the events in Denmark showed that it was politically possible to get a law with only a few exceptions to the heterosexual marriage law. The Swedish gay and lesbian movement began to work harder for a partnership law and got the backing of some prominent politicians. In I990, the National Board of Health and Social Affairs (Socialstyrelsen) presented a draft proposal of a Danish-model partnership law to the Government. It was not the usual procedure that a Government agency produced law proposals, but as a result of the report of the Homo Commission, the Government had commissioned the Socialstyrelsen to work for the well-being of homosexual citizens. Their proposal received wide media coverage, but it did not lead to any Government initiative. ${ }^{69}$

The conservative resistance to the law proved stronger than expected in Sweden. The question was perceived as sensitive by party leadership across the political spectrum, but it seems that the grassroots in some cases were more open to the new ideas. At the Social Democratic Party Congress in 1992, the party's national board recommended a wait-and-see policy and called for further investigation..$^{\circ}$ However, lesbians and gays within the party had managed to influence 
grassroots members, and a majority of delegates carried a binding resolution, instructing the party's steering committee to work actively for a law on registered partnership. Instead of presenting a Government proposal, however, the Social Democratic Government appointed yet another commission of inquiry. This was not appreciated by the gay and lesbian movement. "We were against it," former RFSL chair Tobias Wikström said in an interview, "because we thought it was a way to bury the question. And we went crazy when we heard that Barbro Westerholm had agreed to chair it. It is unusual that a Social Democratic government appoints a commission with a chair from the bourgeois block, and we thought it was a dirty trick. She was one of those who had fought hardest for this thing in Parliament and now she would be chained to a commission as its chair, and she would have to be diplomatic and, so to say, disconnected from politics." ${ }^{11}$ Westerholm herself has interpreted it another way. The reason she accepted the task was that she thought it would provide continuity. Opinion polls indicated that there would be a right wing government after the next election, and with a chair from the People's Party, this commission stood a better chance of surviving into the next electoral period..$^{2}$ In hindsight, it seems obvious that it was, in fact, a way to stall the question. Influential people in the Social Democratic leadership were against the new law, and despite the decisions of the Party Congress, the steering committee had no wish to hasten the process.

The Commission on Registered Partnership was to exist for two years, and its work was marked by conflict and obstruction. When it finally presented its report in 1993, it was split on the question and it was only the decisive vote of the chair that made it tip over in favour of a law on registered partnership.73 The Social Democrats had lost the elections in I99I, and there was now a coalition government of the conservative Moderates (Moderata Samlingspartiet), the Centre Party (Centern), the liberal People's Party (Folkpartiet), and the Christian Democrats (Kristen Demokratisk Samling). The new Government could not agree to present a proposal, but there was a majority for a partnership law in the Riksdag. Thus the new law was prepared entirely by the Parliament's Standing Law Committee (Lagutskottet). It was the first time in the history of Sweden's I97I Constitution that a law was prepared without passing the Government's office, and some of its critics claimed that the procedure was unconstitutional. ${ }^{74}$

When the law finally was voted upon, on 7 June 1994, it caused a six-hour debate, in which its opponents practiced a mild form of filibustering. In the end, however, it was carried by a majority of 30 votes, and just as in Norway three years before, there was cheering from the gallery. RFSL activist Eva Ahlberg, who had worked hard for the law, was there, and at a seminar ten years later she told the audience: "When the voting was over and I saw the numbers on the electronic board, I was so moved that I cried. Feverishly I wrote down the results, because I had to bring them back to the office. And in the middle of this emotional chaos, Jeanette proposed to me!" Eva and her partner Jeanette Öberg 
chose not to be in the first group who were registered at the official ceremony staged by RFSL, but they registered a little later in a private ceremony.75

The law became effective on I January 1995. As in Norway there would be a delay of a couple of days while the wedding licences were issued. In some instances, however, local governments granted exceptions, and on the first workday after New Year's, on January 2, a gay couple was registered in Östersund. The partnership registrar was Jörn Svensson, the Communist MP who had worked for gay and lesbian emancipation for many years. On the same day, two gay couples were registered in the Stockholm City Court by Judge Carl-Anton Spaak, and one lesbian and one gay couple were united by a joint ceremony in the little town of Tidaholm. ${ }^{76}$ Typically, the local newspaper in Tidaholm published a photo of the male couple only on its front page, with the heading "First couple out". Inside the newspaper, however, there was a picture of both couples. The partnership registrar, Birgitta Svahn, was a young woman working in the municipal office who had stepped in because the usual registrar refused to perform the ceremony. ${ }^{77}$

At the official ceremony in Stockholm City Hall on 6 January 1995, arranged by the RFSL, the chair of Stockholm's City Council registered three lesbian and four gay couples. After the ceremony they rode to the RFSL Centre in horsedrawn carriages, and there was a grand wedding party. The forms of partnership registrations were becoming established and in every single detail followed traditional weddings..$^{8}$

To sum up, the process leading to gay marriage in Norway and Sweden displayed many similarities. Both countries had reluctant gay and lesbian movements that did not begin lobbying for partnership until they were electrified by the Danish experience. Also, they both had a strong Christian opposition in the countryside, as well as shifting coalition politics that made it necessary to count each vote in the Parliament. In both countries there was a heated debate in the newspapers, bringing out the most vehement anti-homosexual arguments alongside a passionate defence of the rights of same-sex couples. By contrast, the situations differed considerably in the western periphery of the Nordic area. Iceland, Greenland, and the Faroe Islands displayed, among them, completely different reactions to the Danish partnership law, as the concept of homosexual couples spread to these sparsely populated nations.

\section{The North Atlantic}

Toward the end of the I980s, attitudes to homosexuality in Iceland changed dramatically. As more and more lesbian and gay Icelanders decided to be open, and, above all, remain in the country, the compact homophobia began to erode. More and more straight Icelanders were influenced by openly lesbian and gay friends and relatives. Socialist MP Kristín S. Kvaran was a personal friend of 
Guðni Baldursson, one of the first chairs of Samtökin '78. In 1985 she proposed a number of measures to counteract discrimination against lesbian and gay citizens, but the resistance in the Alpingi was too strong, and her proposal was buried in a Standing Committee..$^{79}$ Seven years later, Ingibjörg Sólrun Gísladóttir from the Women's List was more successful. Through her job as editor for a feminist journal she had got to know several lesbians and gay men. Together with gay activist Porvaldur Kristinsson she prepared the 1992 proposal to appoint a Homo Commission. Before presenting it, she went out to persuade members from the other parties to sign the bill. "I thought it would be better for the cause if I could find one from each party, so that it wouldn't come from just my party. Because then it would be considered a minor matter, because it came from the Women's List." She sought out members whom she knew felt strongly for human rights issues, or who had openly lesbian and gay family members. ${ }^{80}$ The strong emphasis on consensus is typical for Iceland in this matter, and when the partnership law was finally presented to the Alpingi in 1996, only one MP argued against it. Other MPs expressed their pride in the fact that the Icelandic law went one step further than the existing laws in Denmark, Norway, and Sweden. Like the existing law on registered cohabitation for different-sex couples, the Icelandic partnership law would contain a possibility for joint custody of children. This was partly a result of the Icelandic lesbian and gay movement's insistence on equal conditions for same-sex and different-sex couples, but it also showed that public opinion in Iceland was prepared to go further in recognising lesbian and gay rights. ${ }^{8 \mathrm{r}}$ Another difference was that the Icelanders, always sensitive about language, chose not to call it "registered partnership" but "confirmed partnership" (staðfest samvist). There was already a law on registered cohabitation (skrád sambúd) for heterosexual couples, and the lesbian and gay movement insisted that their partnerships should not be registered but confirmed. ${ }^{82}$ When the law was finally put to a vote, it was carried with 44 votes against $\mathrm{I}$. On the recommendation of Samtökin'78, the new law became effective on Christopher Street Day, 27 June $1996 .{ }^{83}$

The new law was born in a spirit of national pride, which was shown by the high level of the dignitaries present at the official celebration. There was a religious service in the Free Church at midnight, and the next day three couples were registered, two female and one male. ${ }^{84}$ At the reception in the City Theatre, the President of the Republic, Vigdis Finnbogadóttir, became the first head of state to attend such an event. Overall, there was rejoicing, which contrasted sharply with the embarrassed silence that had surrounded homosexuality only years earlier. ${ }^{85}$

On July i, one week after the Icelandic partnership law, the Danish law became effective in Greenland, but the legal process had begun long before. Since Greenland is an autonomous part of the Danish kingdom, its local legislature has the right to adopt or reject most laws enacted in Denmark, and it can also 
propose laws valid only in Greenland. With 56,000 inhabitants scattered over a vast area, Greenland has never provided the urban culture that was the breeding ground for homosexual subcultures and the rise of gay and lesbian consciousness. Social control has always been strict, but the prevailing social climate is one of tolerance, and the introduction of the partnership law was smooth and stirred no debate. In 1993 a new Marriage Law became effective in Greenland. The following year, the then Minister of Social Affairs, Henriette Rasmussen, proposed that the Danish law on registered partnership should also be enacted. "The background for this proposal is that this year is the United Nations'Year of the Family, and it is important to establish that there are family forms other than the nuclear family," she said when she presented the proposal. ${ }^{86}$

The debate in the Greenlandic Parliament, the Inatsisartut (or Landsting), was short and sober. Most members voiced their support for the proposal, but there were some critical voices. One member opposed even discussing the matter, saying: "If the insects could hear about this, they would surely laugh at us. Even the smallest creatures know, each in its own way, how life shall be passed on." But even he did not vote against the proposal in the end. Otto Steenholt, leader of the moderately conservative party Atassut, who five years earlier had voted against the Danish law when he was Greenland's representative in the Danish Folketing, said that he was not opposed to the law as such but that he wanted it to be discussed in the Greenlandic community before they voted on it. Some of the members expressed a concern that this was not consistent with Greenlandic culture, and the member most opposed to the law said that there were certain areas where Greenlanders were so far from Danes that they could not easily be discussed. The final proposal to ask the Danish Government to make the law on registered partnership effective in Greenland was carried by 15 votes and $\mathrm{I} 2$ abstentions. No one voted against it. ${ }^{87}$

Subsequently there was some debate in the Greenlandic press, but there seemed to be a consensus that a law on registered partnership was a good thing, and that those members of the Inatsisartut who had spoken against it were prejudiced. After the Parliament's decision, however, it took more than two years for it to work its way through Danish bureaucracy, probably a sign that the question had a low priority in both capitals. It was not asked to be speeded up in Nuuk, and it was not pressed for in Copenhagen. When the law was made effective in Greenland by a Royal Danish Decree on I July 1996, there was no media coverage whatsoever, and it was not until 2002 that any gay Greenlandic couple used the opportunity to register. ${ }^{88}$

Unlike in Greenland, there has been a lively debate on homosexuality and the partnership law in the Faroe Islands, and to date the Faroese Parliament, the Logting, has flatly refused to introduce the Danish law on registered partnership in its territory. Because of a strong Christian conservative lobby, and because of its colonial aversion against anything coming from Denmark, many liberal law 


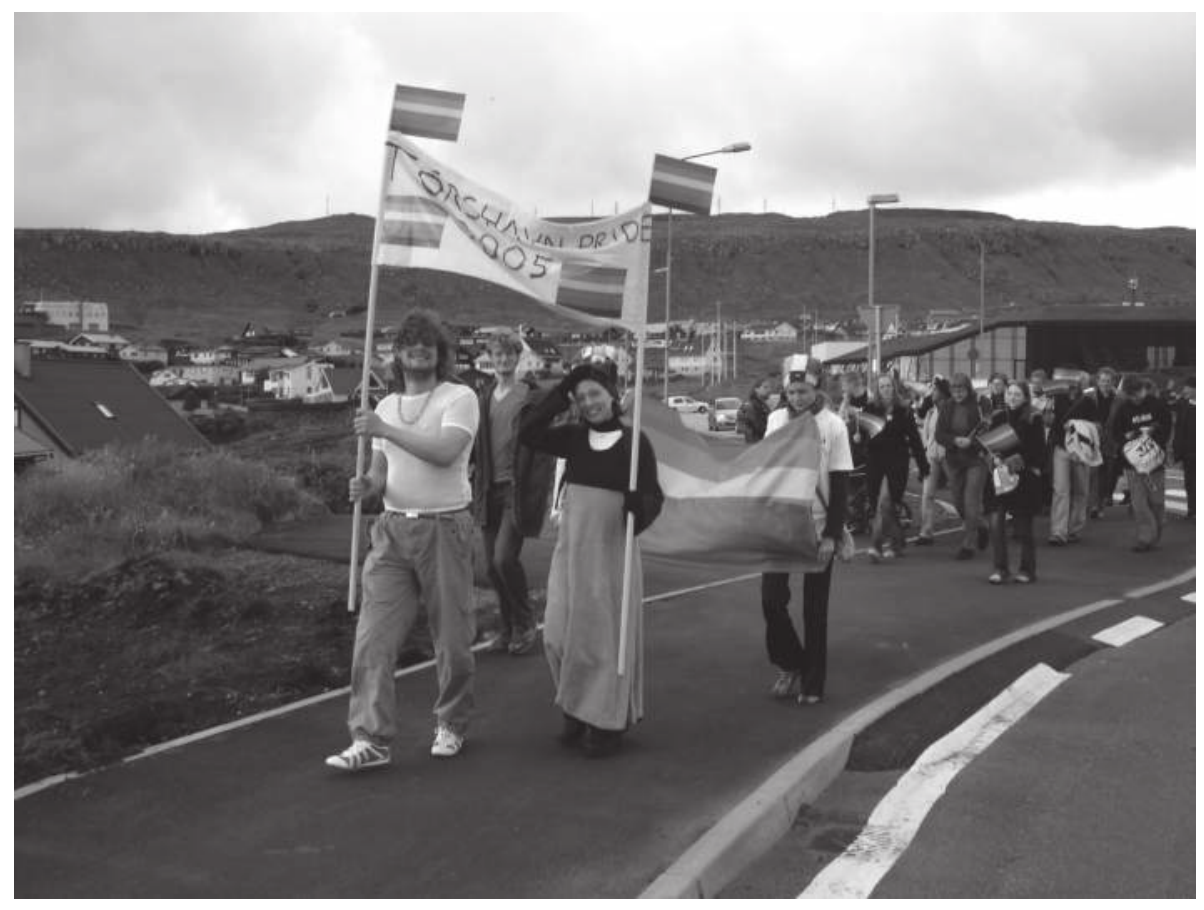

The Tórshavn Pride March in August 2005 resulted in an initiative to introduce a clause against defamation on grounds of sexual orientation, but it was defeated in the first round. Photo: Jens Rydström.

reforms have never been implemented in the Faroes. The abortion law is still very restrictive, and in 1988 a proposal to introduce a clause against discrimination on grounds of sexual orientation was rejected by the Logting. There was indeed a gay personality in the Faroese capital of Tórshavn in the I97os and I980s, Rólant Samuelsen, who was a hairdresser and amateur actor. His sharp tongue and elegant wit made sure that the Faroese could not altogether deny the existence of homosexuality and bisexuality. After his premature death in 1992, his friend and doctor Bogi Davidsen suggested that the Faroes should introduce the Danish partnership law to honour Rólant's memory. Davidsen introduced the new word samkynd for "homosexual," thus avoiding the old, insulting forms, and in 1995 he made a 45-minute-long TV-program about the situation of gays and lesbians in the Faroes. ${ }^{89}$

The Internet made it easier for Faroese lesbians and gays to establish networks, and in 2003 they founded the LGBT group Fridarbogin, which has been highly successful in moving LGBT rights up on the public agenda, but less successful in promoting legal reform. In the summer of 2005 , a Nordic LGBT student conference was held in the Faroes, and it provoked a heated debate in the newspapers. The end of the conference was marked by a Pride March, and ap- 
parently the many homophobic remarks in the press resulted in many people wanting to show their support for the gay and lesbian movement. Almost two hundred people, far more than the organisers had hoped for, showed up and marched through the streets of Tórshavn. ${ }^{\circ}$

The events surrounding the Faroese Pride March inspired new parliamentary action. Two members of the Logting reintroduced a proposal, not for a partnership law, but for a clause against discrimination on grounds of sexual orientation, which had been almost unanimously rejected in $1988.9^{9}$ This time there was a more open debate on the issue, but when the Logting voted on it in December 2005 it failed again and the question seemed to be politically dead for a considerable time. ${ }^{92}$ One year later, however, a homophobic assault shocked the Faroese and after a heated debate the anti-discrimination clause was adopted with ${ }^{2} 7$ votes in favour and ${ }_{5} 5$ against. ${ }^{93}$ The law on registered partnership has never been proposed to the Logting to vote on, and it does not seem likely that it will be introduced in the near future. All political parties are split over the issue, and since the present Government depends on the support from the morally conservative Centre Party (Midflokkurin), it will take no new initiatives in that direction. However, a new electoral system resulted in less influence from the rural consituencies and more women in Parliament. Given that there is also political pressure from the other countries in the Nordic Council, the long-term prognosis for introducing a partnership law also on the Faroe Islands seems, after all, rather positive. ${ }^{94}$

Thus, the small states in the western periphery of the Nordic area have reacted very differently to the challenge of same-sex unions. Iceland enthusiastically embraced the new order, Greenland accepted it without much debate, and the Faroes flatly refused to introduce it. On the eastern border of Scandinavia, Finland went through an extended period of lobbying for a partnership law, while at the same time the opposition to the law managed to delay it so that Finland became the last independent Nordic country to introduce the law.

\section{Finland: Fierce opposition}

During the Cold War, Finland was locked in position as a pawn in the game of European security and had to tread very carefully in foreign politics, which also influenced internal politics. Presidential power was exceptionally strong under Urho Kekkonen, who was President from 1956 to 1982. The rigid political atmosphere, combined with traumatic war memories, helped reinforce the speculation that homosexuality was something that was done in Sweden, and that it was foreign to Finnish culture. ${ }^{95}$ Both male and female homosexuality was outlawed until I97I. After that, the higher age of consent for homosexual acts was in force until I999, and during the same period there was also a special clause prohibiting the encouragement of homosexuality. Partly because of this homophobic 
climate, and partly for ideological reasons, registered partnership was not on the agenda of the gay and lesbian movement. ${ }^{96}$

But all this was to change in the I99os. One of those who would work politically for gay and lesbian rights was Social Democratic MP - and future President of the Republic - Tarja Halonen. She was a lawyer and took a keen interest in human rights issues, and in I980 she published the country's first scholarly article on legislation that discriminated against homosexuals. At that time, it was, above all, the higher age of consent for same-sex sexual acts and the ban on "encouragement" that attracted attention, but she also mentioned the need for a regulation of same-sex relationships. ${ }^{97}$ Elected to Parliament in 1979, she accepted an invitation from SETA to give a speech at the Gay Liberation Week in Helsinki the same year, and during her time as MP she presented several bills to reform the criminal law regarding homosexuality. In I 980 she became chair of SETA, following a tradition that the Finnish gay and lesbian association often chose prominent straight politicians as their spokespersons. When Halonen became Minister of Justice in 1990, many lesbian and gay activists hoped that she would work more actively for a law on registered partnership but she chose the slow path, knowing that resistance to such a law was strong. She created a Family Law Commission and appointed a member from SETA to be part of it. In its report it acknowledged the need for registered partnership legislation, without, however, proposing any concrete measures..$^{98}$

As in all other Scandinavian countries, the political initiative to a law on registered partnership came from the left and from female politicians. In 1993, Outi Ojala from the Left Alliance (Vasemmistoliitto / Vänsterförbundet) presented a bill to the Finnish Parliament, the Eduskunta, demanding a law on registered partnership. She worked hard for gay rights in the Finnish Parliament, but she was not the one who wrote the law proposal. "I have to admit that it was I who wrote the bill," Jorma Hentilä said when he was interviewed. He was the party secretary of the Left Alliance's predecessor, a left umbrella organisation called the Finnish People's Democratic Alliance (SKDL/DFFF), from 1977 to 1983 , and chair of SETA from 1983 to 1991. After the parliamentary elections in I99I, Hentilä formulated a radical bill that included adoption rights and the right of same-sex couples to be treated equally as different-sex married couples. Ojala presented the bill and then asked MPs to support it. "But it wasn't easy," Hentilä said. "There were perhaps ten MPs who were prepared to sign." ${ }^{99}$ Ojala's - and Hentilä's - I993 parliamentary bill did not make it past the Parliament's Standing Law Committee, but it was debated and had considerable influence.

In the summer of 1994, SETA organised a Pride Party in Esplanadi Park in central Helsinki, where four same-sex couples - one female and three male staged wedding ceremonies in order to influence public opinion. The event was widely publicised and many people remember it as provocative and fun. ${ }^{100} \mathrm{How}^{-}$ ever, conservative resistance against partnership was strong and deeply rooted. 
There were two kinds of religious resistance, according to Rainer Hiltunen, who was then Secretary General of SETA. There was opposition from fundamentalist Christians, but according to Hiltunen "it was not that dangerous, and sometimes it was even beneficial, because their rhetoric was sometimes so ridiculous that people didn't want to be associated with it." The second kind of resistance was that of the Lutheran State Church, which was more dangerous to the cause. "It was the Lutheran Church that nearly defeated us. The politicians listened to them." In the Finnish Parliament, all parties were split over the question, except the Christian Democrats, who were unanimously against the law. ${ }^{\text {Ior }}$

Two things that distinguished the Finnish campaign from the countries in central Scandinavia were: the high level of lesbian participation, and the fact that the Finnish gay and lesbian movement never let go of their demand that the law should allow for joint adoption and artificial insemination for lesbian couples. These factors made the Finnish campaign look more like the one in Iceland. During the I990s, SETA had only lesbian chairpersons, most of them mothers with a high public profile. Tiina Kivinen, who was chair of SETA I99I-I994, remembered during her interview that the lesbian baby-boom at the beginning of the nineties changed the discourse and made lesbians more interested in partnership issues. "I got my daughter in I980 and I got many letters and telephone calls from lesbians who wanted to know about it," she said. "I think that changed the discussion, and many thought we needed legislation to protect our children." Another key figure was Hannele Lehtikuusi, organisational secretary of the Green Alliance and chair of SETA after Tiina Kivinen. Lehtikuusi was instrumental in giving the Finnish campaign such a high concentration of lesbians and gays with children. Tragically, she died of cancer at forty-four in 2004. In an interview, Kati Mustola remembers that "throughout the nineties SETA had female chairpersons who had children. It turned into a league of lesbian mothers." At that time there was some internal opposition on activists' e-mail list. Some members - mostly gay men - thought it was not tactically wise to pursue the pro-adoption line, but "Haski [as Hannele was called] was steel-hard in saying that 'no, we want the whole cake!" According to Mustola, lesbian and gay activists in Finland knew very well that all reforms are achieved one step at a time, and that it would probably not be possible to get adoption rights at once. But their tactics were to demand "the whole cake" at this stage in order to push their bargaining position as far as possible. It was probably Lehtikuusi's influence in the Green Alliance that resulted in their firm stand on adoption rights. Their condition to support the Government's law proposal was that it immediately appoint a commission to investigate the need of adoption rights for samesex couples. ${ }^{\text {I02 }}$

A media event that highly influenced the Finnish debate was the registered partnership ceremony of Swedish singer-songwriter Eva Dahlgren and designer Efwa Attling in January 1996. Dahlgren was very popular in Finland and the 


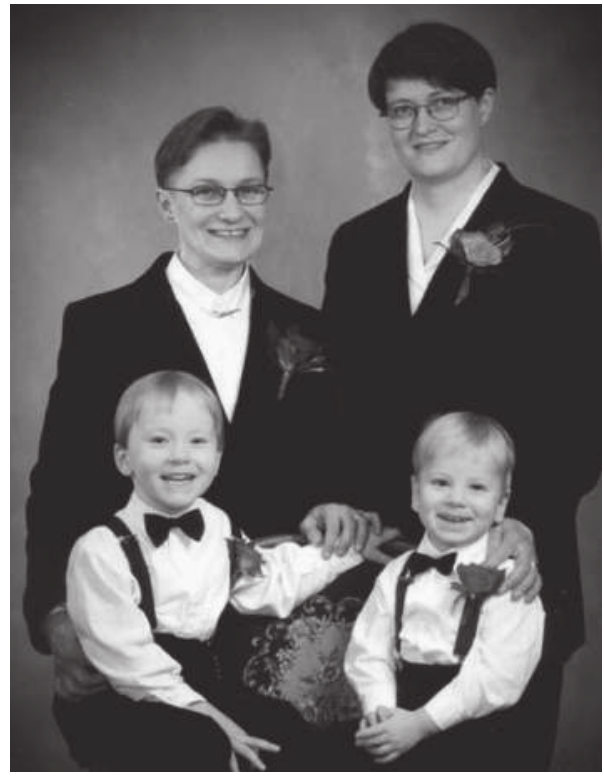

Hanna Räty and Hannele Lehtikuusi were one of the lesbian couples with children that appeared frequently in the Finnish press in the 1990s. Photo: Kuvasiskot, Helsinki.

union got wide media coverage. Many writers thought it an outrage that her loving commitment to Attling could be officially recognised in Sweden, but not in Finland. Images of the two happy and successful women appeared in the Finnish press, and proponents of the partnership law used them as a positive example of how such a law could bring happiness to some people without threatening the majority. ${ }^{\mathrm{IO}}$

In 1996 there was a new motion in the Eduskunta. This time the ground had been laid for a more positive treatment, but the broad coalition Government's Minister of Justice was Kari Häkämies, from the conservative National Coalition Party (Kokoomus / Samlingspartiet), who opposed the law. He declared to the press that "nothing will happen concerning this question during this government's mandate," and hope sank for a speedy reform. ${ }^{104}$ However, the motion was positively treated in the Parliament's Law Committee, and in 1997 the Government appointed a commission with representatives from various ministries and Rainer Hiltunen from SETA. The commission delivered its report in 1999, and they recommended that Parliament pass a law on registered partnership much like the ones in the other Scandinavian countries.

Rainer Hiltunen wrote a dissenting opinion to the commission's report and demanded that registered partnership should include the right of joint adoption and of artificial insemination for lesbians. This way, SETA again revealed a strategy different from the gay and lesbian movements in central Scandinavia. It was a result of the increasing involvement of lesbians in the movement, and a sign that the idea of homosexuality was becoming more and more associated with procreation and child rearing at the end of the 1990s. ${ }^{\text {Ios }}$ In the last minute 
some minor amendments were made by the Standing Law Committee. Registered partners were not to be allowed to take a joint last name, and the term for the new institution that was preferred by the gay and lesbian movement, virallistettu parisubde, literally "official partnership," was rejected. Instead, it was called rekisteröity parisubde, "registered partnership," which to some Finnish ears recalled the car register or the criminal register. These limitations had a symbolic meaning that was all too clear to those concerned. Kati Mustola commented: "It had hardly any practical importance, but it was just to show us gays and lesbians our place. That we were worth less in society's eyes." ${ }^{\circ \circ 6}$ In this respect, the attitudes of the Finnish authorities contrasted sharply with those of the Icelandic legislators, who agreed to call the law "confirmed partnership" instead of "registered partnership".

The day the Finnish law was passed, 28 September 200I, the stairs in front of the Parliament building were covered with gays and lesbians waiting to get in. The security check was rigorous, and many of those waiting were still outside when the law proposal was dealt with. A group of Christian fundamentalists also stood on the stairs, kneeling and praying for the proposal to fail. But inside the building it was passed with 99 votes in favour and 84 against - a slim 54 percent majority. The people in the spectators' section burst out in applause and were silenced by the Speaker. Kati Mustola was among the activists on the stairs outside when the news came to them via mobile phones. There were cheers and rejoicing, but no champagne. Only one lesbian couple had brought a mini bottle - hardly enough to share with everybody. Kati Mustola remembers that "we were so afraid of being disappointed that it didn't even occur to me that I should have brought some champagne." But Rainer Hiltunen invited the crowd to celebrate in the nearby gay and lesbian restaurant "Don't tell Mama," where SETA offered everybody a glass. ${ }^{107}$ On 8 March 2002, when the law took effect, there were no public celebrations. SETA did not arrange a public ceremony, and SETA's magazine Z-lehti did not show wedding couples on its front cover, though it did run a long interview with a lesbian and a gay couple. ${ }^{\text {108 }}$ When Finland finally got its law, the Netherlands and even Germany and France had already got theirs, and there was a sense of disappointment that the politicians had delayed the reform so many years. ${ }^{\text {109 }}$

Finland was the last country of the five independent members of the Nordic Council to introduce registered partnership, and the enthusiasm and celebratory mood that had characterised its introduction in other countries was largely absent. Evidently the Finnish political left had underestimated the strength of the traditionalist forces in the Finnish rural areas. Finland was urbanised later than the other Scandinavian countries, and traditional values are strong in the countryside. In I996, the urban elite thought that the partnership law would be passed without much resistance, and many people were astonished when they realised how strong the opposition really was. The dynamics of Nordic politics, 
however, exert some pressure on governments and influence popular attitudes, and many times the neighbouring countries are held up as examples. It was thus used as an argument against the partnership law in Denmark in 1989 that no other Scandinavian country had such a law, while the fact that the law had already been introduced in most other Nordic countries was used in favour of it in Finland and in the Faroes at the beginning of the twenty-first century.

\section{Conclusions}

Two questions need to be addressed in an overall assessment of the history of the partnership laws in Scandinavia. Why did these laws appear at that precise moment in history, and why did it happen first in Scandinavia? The answer to the first question is necessarily to be sought in the global sexual revolution in the r96os and its further developments in the I970s. Material and institutional prerequisites such as new contraceptives and the liberalisation of abortion laws freed young people from the constraints that the risk of pregnancy had placed on heterosexuality, and this conditioned the ways in which the generational rebels talked and thought about sex in the I96os. In this context, Scandinavia received a somewhat undeserved reputation of being sexually lax. ${ }^{\text {IIO }}$ Same-sex sexuality was one of the aspects discussed during this time, but the homophile movements did not take part in the debate. In the I970s, on the contrary, a vitalised and highly visible gay movement presented new demands of society. As gays moved toward social recognition, legal recognition seemed a logical step to many activists, and their allies in the national parliaments did their best to help.

The AIDS epidemic was hardly ever explicitly used as an argument for introducing laws that officially recognised stable relationships between gay men, but it was important on two levels. First, it created a sense of urgency, that something had to be done about the life situation for gay men, and second, it gave a new status to the lesbian and gay organisations. From being perceived as organisations for an insignificant minority, they became legitimate and responsible actors in the fight against AIDS, which was a concern for the whole society. However, the demands for legal and social recognition of lesbian and gay relationships had been presented well before news of the disease began to emerge. The first Scandinavian AIDS cases were reported in 1983, but the first demands for legal status of same-sex relationships came in Denmark and Sweden in 1968 and 1973 respectively. The first Homo Commission had been appointed in 1977, and new gay and lesbian movements appeared in Finland and Iceland in 1974 and 1978. Fears of gay sex as a source of disease and the wish to discipline gay men definitely played a part in the willingness to accept reform, but these arguments were not addressed in the debate. The whole process was perceived as a benevolent society's response to demands from gay and lesbian activists. Legal preparations had been well on the way in Denmark and Sweden, where the es- 
tablished gay and lesbian movements had opted for gay marriage, when the sudden Danish breakthrough kindled the debate in all the Scandinavian countries.

Why did it happen first in Scandinavia? The answer to that is most probably to be sought in the structure of the Scandinavian welfare states. The historical agreements between farmers' parties and social democratic workers' parties that took place in all Scandinavian countries in the I930s created a strong base for social reform, a base founded on consensus and a willingness to compromise, but also a base which made possible far-reaching encroachments in the individual's life. Thus, the sterilisation campaigns remain a dark chapter in Scandinavian history. ${ }^{\text {II }}$ A specific blend of ideals of conscientiousness and industriousness created a society where the needs of the weak were met and the demands for cooperation and assimilation were strong. In such a society, an "anomaly" like homosexuality could be handled in two ways: by utter rejection, as in the I950s, or by incorporation and assimilation, as in the r980s and I990s. Another important factor in understanding the gradual acceptance of homosexuals as valuable members of society - most striking perhaps in Iceland - is the sense of fairness and equity embedded in Scandinavian social democracy. Once gay and lesbian activists had managed to persuade young Social Democrats to fight for their cause, the question of homosexual emancipation ceased to be an ideological question for liberals and reformed socialists and became a matter of social justice as defined by the broad workers' movement. When the established leadership of the Social Democratic Party was accused of treating homosexuals as less valuable and was asked to defend that position, it had no good answers. If it could not be regarded as self-evident that homosexuality was inferior, as had happened in the I950s, what arguments were left?

Thus the dynamics of the welfare state, and a political process, beginning with the ideological commitment to lesbian and gay rights in a smaller segment of the population and culminating with rapid and decisive changes of attitudes in the majority, have paved the way for the incorporation of the lesbian and gay couple in society. But what ideological shifts among lesbian and gay activists have occurred when preparing this reform? And how have these shifts influenced its reception? In the next chapter, we will investigate the discussions within the lesbian and gay movements in the different Scandinavian countries. 


\section{Chapter Two: Is marriage what we want?}

The demands for legal recognition of same-sex couples are not new. Ceremonies of friendship and other forms of bonding necessarily have copied heterosexual forms for contracting marriage. In I884, the deeply religious Swedish philosopher Pontus Wikner wrote in his secret diary about his love for other men. He deeply regretted the wrongs he had done to his wife, and he suggested a remedy for the suffering he and those who were like him had to endure and had inflicted on others:

Could it not be possible, that an exceptional status be granted to such people who are my equals, so that if they could find a being of their own sex, who could reciprocate their love, they could enter into matrimony with each other? ... Oh humans, humans, be merciful! I know what the Bible says, but could there be no exceptional status for exceptional people? If I could receive this alliance praising God and another person could do the same with me, why could we not be allowed to?

Wikner died in I888, but his secret diary was not published until I97I, more than eighty years after his death. His highly-strung prose was typical for his life and time, but his frank confessions about his erotic feelings for men were not. Apparently he had not read any of the emerging literature about homosexuality and the third sex. For Wikner, his feeling for men was something that had to be negotiated with the Church and with his personal faith. But the world was going to change profoundly after his death, when lesbian and gay organisations appeared and grew in importance. ${ }^{\mathrm{I}}$

There were no organisations for the third sex in Scandinavia before World War Two, even if some individuals had contacts with Magnus Hirschfeld's Institut für Sexualwissenschaft in Berlin. ${ }^{2}$ Between 1948 and I950, however, homophile organisations were founded in Denmark, Norway, and Sweden. By the end of the I950s these movements were rather well established, with their own publications, social events, and political lobby groups manned by volunteers in the capitals, as well as elsewhere. However, they were forced to be discreet and very cautious by the homophobic political climate of the r95os. In Denmark, the socalled pornography affair in 1955 all but crushed "The Society of 1948 " (Forbundet af 1948 ), putting several of its leaders behind bars. ${ }^{3}$ In Norway, "The Norwe- 
gian Society of 1948" (Det Norske Forbundet av 1948, DNF'48) escaped being de facto outlawed in 1953, when a law proposal suggesting the prohibition of public announcements about meetings for homosexual men and women was rejected. ${ }^{4}$ In Sweden, the activists of the RFSL kept a relatively high profile in the early I950s and, among other things, wrote letters to the Swedish Government and the United Nations demanding human rights for homosexuals. After a few years, however, a number of homosexual scandals and a violently homophobic press forced them to lie low. The RFSL had petitioned the Government to investigate the possibility of legally regulating homosexual relations in 1952, but later they wanted to withdraw their demand. ${ }^{5}$ Most activists considered it too risky, or meaningless, to demand gay marriage at this point.

In Norway, the homophile movement successfully averted the danger of being outlawed by consulting a good lawyer and gaining support for their cause among medical and legal professionals. ${ }^{6}$ In 1949, The Danish Society of 1948 filed an application for inclusion in the register of free associations of the Danish Ministry of Commerce, but it was rejected. It was not to be granted until 1969. Instead, they concentrated on organising a Scandinavian network of lesbians and gay men, and its founder, Axel Lundahl Madsen (later Axgil), dreamed of a Scandinavian homophile union under his leadership. However, there were constant tensions between the Danish mother organisation and its Norwegian and Swedish chapters, and in $1955^{-} 53$ they severed their ties with Denmark and became independent organisations. ${ }^{7}$

In the 1960s the homophile movement was not publicly active, but initiatives were taken by other actors. In 1964 a widely publicised meeting in Stockholm, which dealt with a wide range of sexual issues, like pornography, abortion, and extramarital sex, also discussed discrimination against homosexuals. And in 1966 the student housing agency at the University of Uppsala in Sweden declared that homosexual couples would get student apartments according to the same rules as heterosexual couples. This is an early example of how concrete rights for same-sex couples were sought outside the framework of marriage. ${ }^{8}$ In Finland, the ban on homosexual acts led to some protests and debates in the liberal press and among Finnish intellectuals, but there was no organisation for homosexuals that could deal with these problems. ${ }^{9}$ Both Finland and Iceland had to wait until the 1970s before nationwide gay and lesbian organisations were established. The Finnish and Icelandic gay rights movements emerged at the time when the existing homophile movements in other countries had been superseded by more radical gay and lesbian groups of activists.

From the I970s onward the discussion whether to fight for marriage-like arrangements for same-sex couples engaged many activists. The homophile movements in the 1950s had cautiously raised the question, but the new generation that took over in the I97os was split. There were those who advocated some kind of legal partnership for same-sex couples, but they were up against a firm and 
well-formulated resistance from lesbian feminists and anti-establishment sexradicals.

\section{Activism in the 1970 s}

The chair of the national Danish gay and lesbian movement from I970 until 1978 , Per Kleis Bønnelykke, was the person who introduced the concept of "partnership" in the Scandinavian debate. When he became chair of The Society of 1948 there were two issues which interested him most of all. "There were two main areas where you can say that there was no equality," Bønnelykke said in an interview. One was the higher age of consent for homosexual relations, "and the other area was the lack of possibility to get married, to put it simply." For the marriage activism, he was inspired by the Swiss publication Der Kreis, which had argued for a "Partnerschaft" for homosexuals - not marriage, but a partnership. ${ }^{10}$ In 1972 Bønnelykke wrote a letter to the chair of the Danish Marriage Law Commission and pointed out that the commission also had a responsibility for solving problems that homophile couples met because of their inability to marry. He wrote that The Society of 1948 was prepared to accept practical solutions instead of marriage status, and as an example of such a solution he mentioned that homophile couples as well as other "paperless couples" had recently been granted the possibility of getting apartments under the same conditions as married couples. He said that he personally preferred a long-term solution that would mean "an extension of the legal consequences of marriage to a larger part of the population," and he proposed the following wording of a law:

Two persons, who wish to live in a steady relationship, can demand that their partnership be registered by the authorities. In all areas of the law, the registration (recognition) will have the same legal consequences as marriage. The recognition of the relationship presupposes the consent of both parties. Dissolution will take place if at least one of the parties so wishes, and follows the same rules as a divorce."I

This was the first time that the word "partnership" was used in a formal letter to a government agency, even if approximately the same rules and procedures had been suggested in the Socialist People's Party's law proposal from i968. Bønnelykke's letter was followed by an intense campaign for registered partnership within The Society of 1948..$^{\text {I2 }}$ The Marriage Law Commission, however, did not take into consideration Bønnelykke's suggestions, and its published reports contained no provisions for same-sex couples. ${ }^{13}$ After this failed intervention, Bønnelykke and The Society of 1948 gave priority to the fight against the higher age of consent for gay sex and were successful in 1976. Until then, the discussion about gay marriage was less intense within the movement, and even afterwards there was no majority for it in the steering committee of The Society of 
I948. "There was an attitude that marriage should be reserved for heterosexuals ... and there were, in particular, women who thought that marriage itself was a ghastly institution," Bønnelykke said. ${ }^{\mathrm{T}}{ }^{4}$

As mentioned earlier, The Norwegian Society of 1948 (DNF' 48) firmly rejected the idea of "homophile marriages." At its General Assembly in 1973, the steering committee proposed a resolution with the title "No to homophile marriage!" The national chair, Kim Friele, presented the proposal, saying that since the law prohibiting male homosexuality had been abolished, DNF ' 48 had to consider its new fields of action. In neighbouring Denmark and Sweden, the ongoing revision of the marriage laws had resulted in debates around the legal situation for same-sex couples, but Friele was of the opinion that marriage gave unjust advantages to those who had a partner, at the expense of those who did not. At the meeting, some members opposed the wording of the resolution, and especially its title. After some discussion, the resolution was accepted with a revised heading: "Yes to homophile relations - No to marriage in the traditional way!" The resolution was carried with only one vote against, and it read in its entirety:

I. The value of the individual is not dependent on his or her ability, will, or possibility to couple with another individual.

2. The Norwegian Society of 1948 cannot accept any form of discrimination against unmarried people, economic or social. The Society will support any politics that has as its purpose the removal of this discrimination wherever it is found. The Norwegian Society of 1948 will also work to defend other forms of relations than traditional marriage. ${ }^{15}$

This resolution was to determine the Norwegian gay and lesbian movement's stand on gay marriage for a long time. As discussed in Chapter One, the Norwegian movement was split in two, the $\mathrm{DNF}^{\prime}{ }^{4} 8$ and the $\mathrm{FHO}$, between 1978 and 1992, but neither of the two organisations gave any priority to gay marriage or registered partnership. In 1984 two prominent FHO members expressed the view that there was a need for a discussion of strategies in both organisations.

What alternative life forms can we as lesbians and gay men inspire others to in the future? We stand outside the nuclear family, and from a freer perspective we could perhaps counter the privatising role of the family. Equality between homo and hetero must mean equal rights to sexuality, not the adoption of the nuclear family's ideals. ${ }^{16}$

The DNF' 48 and the FHO existed side by side for thirteen years, but their actual politics differed very little. The common cause which gave the direct reason for the merger of the two organisations was the lobbying effort for the law 
on registered partnership. Representatives from both groups participated in the working group for registered partnership, and as a result of their efforts Norway not only got a partnership law, but also a unified lesbian and gay national organisation, as the DNF' 48 and $\mathrm{FHO}$ joined their forces in the new organisation. On 29 November I992, the two organisations merged and formed LLH, The National Union for Lesbian and Gay Liberation (Landsforeningen for Lesbisk og Homofil Frigjoring). ${ }^{17}$

In Sweden, pragmatic leaders such as Stig-Åke Petersson (chair of the RFSL I97I-72 and I984-88) worked for equality between homosexual and heterosexual couples. "We did not have any opinion on marriage as such, but we thought that what applied to heterophiles should also be applied to us ... I don't remember if we demanded marriage or only that the same rules should apply," he said in an interview. ${ }^{18}$ When the Swedish Family Law Commission (Familjelagssakkunniga) presented its law proposal in 1972 , in which same-sex families were not mentioned, the RFSL wrote to all the governmental and non-governmental agencies consulted by the Family Law Commission and presented their differing opinion. Some of the agencies, most importantly the National Board of Health and Social Affairs (Socialstyrelsen) and the Social Democratic Party's Youth League (SSU), responded positively to RFSL's letter and mentioned it in their comments to the Government. Another RFSL initiative during those years was to demand that the Swedish Immigration Authority (Invandrarverket) should treat same-sex couples the same way as unmarried different-sex couples when one of the partners asked for a residence permit in Sweden. This action was done entirely by corresponding with the civil servants of the Immigration Authority, and the question was never brought to the political level. "Perhaps that was the reason it was so easy to get it through," Petersson said. ${ }^{19}$

The work that was done during the late i97os set the agenda for RFSL, and it was then that it earned its reputation in neighbouring countries of being a reformist, rather conservative organisation, aiming for gay marriage. "Both Norwegians and Danes made fun of us," Petersson remembers. "They were more radical." His impression is corroborated by Norwegian activist Kim Friele, who mentioned in an interview that the Swedes were "a little more bourgeois, a little cautious ... And we made fun of the Swedes at that time. We depicted them with scarves and flower pots and so on." According to Friele, the main difference was the way the organisations wanted to regulate same-sex marriages. The Swedes did it their way, she says, and "they couldn't move on from traditional marriage. But there was a lot of debate between the countries." ${ }^{\circ \circ}$ In I982, Kim Friele was invited to speak during the Stockholm Gay Liberation week and took the opportunity to criticise the RFSL for their commitment to marriage. This provoked some sour reactions from the RFSL, but Norwegian activists reacted in different ways. Some thought Friele's speech an embarrassing interference in Swedish gay politics, though the Swedish activist Calle Almedal, who 
had lived in Norway for ten years, wholeheartedly supported her views. He wanted the gay movement to strive for the same opportunity as heterosexuals "without having to be forced to accept the prerequisites of heterosexual society." Many others, however, criticised Friele for choosing such a moment to strike at RFSL's policy. ${ }^{2 \mathrm{I}}$

The political stand on marriage was thus very different among the Nordic countries, and in the beginning of the I980s these differing opinions had been firmly institutionalised. The Icelandic delegation reported back from a Nordic meeting in Copenhagen in I98I that all gay and lesbian organisations had diverging views on the partnership issue. According to the report, the Swedish RFSL demanded the same rights for same-sex couples as married and cohabiting heterosexual couples. The Finnish organisation had not yet a firm standpoint on the issue, but the Danish, Icelandic, and Norwegian organisations "are against the uncritical adoption of the division between married people and others, a division that makes a difference between first and second class citizens." The problem was, they pointed out, that married people were given rights that they did not have before entering marriage, rights thus not granted to those who chose to organise their lives in other ways. According to the report, the Danish, Icelandic, and Norwegian organisations refused to divide the group of gays and lesbians into first and second class citizens. "On the contrary, these groups are of the opinion that people living together, regardless of sex and regardless of how many they are, should be able to organise their private affairs, like their economy, in the way they choose." 22 The arguments here mirror the radical politics that prevailed in the 1970 . Marriage for homosexuals was rejected on grounds of solidarity and equality, and the coupling of two individuals was not seen as the exclusive form of human bonding.

The Icelandic movement was small, but it nevertheless hosted a variety of attitudes to the partnership law. Lana Kolbrún Eddudóttir, who was chair of Samtökin ' 78 in I988-90 and I993-94, remembered the stormy meetings of Samtökin ' 78 in the beginning of the I990s, where she encountered criticism from both feminists and gay men. One of those who originally were against the partnership law was Margrét Pála Ólafsdóttir, who later became chair of Samtökin. When she had recently been elected, she gave an interview in the journal Sjónarhorn, where she aired her misgivings about the new law. She said she had both positive and negative feelings about the fight for it. She felt strongly that the lesbian and gay movement should not accept "half a share" too easily. "Now, according to the majority of the committee, we will be allowed to exist with limited civil rights," she said. She vowed to work hard for the law, but she thought that the lesbian and gay activists must try to influence the MPs "so that we are not served scantily with civil rights as second-rate citizens from here to eternity." ${ }^{23}$ Her argument clearly refers to the restrictions put upon the law in all Scandinavian countries, that it did not include custody over children 
and the right to marry in Church, nor was it open to foreign citizens. These restrictions had been accepted by the gay movements as a pragmatic way of getting the law through at all, but for many activists they were unacceptable. According to an interview she gave to Anna Einarsdóttir, Margrét Pála influenced Samtökin's representatives in the Government Commission, Lana Kolbrún and Guðni Baldursson, to dissent more strongly from the commission. At any rate, Lana's and Guðni's minority statement finally had the effect that the Icelandic law granted joint custody to registered partners with children. ${ }^{24}$

\section{Feminist resistance}

Before the law on registered partnership became a reality, there was, especially in Denmark, an outspoken lesbian resistance to the proposal. When the law was adopted in Denmark in 1989, lesbian activist Else Slange was chair of the LBL. Slange never publicly opposed the law, but she was clearly sceptical. In an interview, she remembered that many women were against the law, and their arguments had to do with the dependency and subordination of women.

Why do we need that petit-bourgeois, well ...crap?! We were strong women who could get by on our own, and what did women work for throughout the seventies? To become independent, to be valued, to be themselves! To become something in their own right, not as an appendix to another person. ${ }^{25}$

Because of their feminist commitment to women's independency, Danish lesbians opposed a law that again would make women dependent economically on another person. Slange pointed out, however, that there were problems in not having regulated inheritance. There were instances in which one of a couple died and the other inherited nothing. As for many lesbians, the question presented a dilemma for Slange, and neither she nor any of her lesbian activist friends actively opposed the law. ${ }^{26}$

Feminist resistance to any kind of marriage-like arrangements for same-sex couples was firmly rooted in the second-wave feminism of the I970s, for which materialist theories of patriarchy played an important part. When U.S. economist Heidi Hartmann published her influential article "The unhappy marriage between Marxism and Feminism” in 1979, she strove to combine a Marxist materialistic worldview, departing from the class struggle, with a feminist analysis investigating the exploitation of female labour in the capitalist system. In order to understand patriarchal capitalism, she wrote, we must examine all aspects of it:

The crucial elements of patriarchy as we currently experience them are: heterosexual marriage (and consequent homophobia), female child-rearing and house- 
work, women's economic dependence on men (enforced by arrangements in the labor market), the state, and numerous institutions based on social relations among men - clubs, sports, unions, professions, universities, churches, corporations, and armies. All of these elements need to be examined if we are to understand patriarchal capitalism. ${ }^{27}$

Hartmann and other dual-system theorists were influential among Scandinavian feminists, and wherever there was a strong independent lesbian movement, there was also strong feminist resistance to the law. But the most influential text among Scandinavian lesbian feminists was by far "The Woman-Identified Woman" by Radicalesbians - a manifesto that had been used to open the debate on lesbian issues at the Second Congress to Unite Women in New York in r970. It was translated into different Scandinavian languages soon after its appearance in the United States and influenced the self-image and political standpoints of a generation of lesbians. The manifesto departs from the fact that men's definition of "woman" leads to a thwarted self-image and self-hatred among all women. A woman is only recognised as such if she is attached to a man, it said: "We are authentic, legitimate, real to the extent that we are the property of some man whose name we bear." ${ }^{28}$ It further maintained that "in exchange for our psychic servicing and for performing society's non-profit-making functions, the man confers on us just one thing: the slave status which makes us legitimate in the eyes of the society in which we live." This fundamental criticism of marriage was thus highly influential among lesbian women in Europe and in the United States, and it is no wonder that lesbians did not support the idea of a marriagelike institution for same-sex couples as wholeheartedly as most gay men did.

In I98I, when asked for their opinion on a proposal to give same-sex couples recognition by a separate registration, the Swedish group Lesbian Feminists (Lesbiska Feminister) wrote: "For a lesbian feminist to support this patriarchal institution, marriage, would be an insult to women's liberation." ${ }^{29}$ In Finland there was an overall sceptical attitude concerning the law within the movement in the I980s, and Jorma Hentilä explained it by pointing to the strong feminist movement: "We weren't that interested in the partnership law, and I think one reason was that among the lesbians at the time there were radical feminist lines of thought ... and anything that was similar to marriage was no good. You didn't want to adopt the forms that heterosexuals had." $3 \circ$

To explain the Finnish feminist reluctance to accept gay marriage, Terhi Saarinen, lesbian activist in the I980s, said: "My ideology was more about free love or serial monogamy and such. But I was a young person."When she was interviewed, Saarinen had changed, and so had Finnish society. "The situation was so different compared to today because life was so hard, and we were so invisible and there were still very discriminating laws in those days ... So it was so faraway to think about registering and so on." ${ }^{\text {I }}$ The lack of interest in Finland can 
thus be explained, on the one hand, by an ideologically based resistance to petitbourgeois norms and, on the other, by the fact that such a law was perceived as very far from the current political reality.

Feminist resistance to the law, however, was by no means limited to the I970s and the ig8os. Lana Kolbrún told me that there were clearly formulated feminist arguments against it at some stormy meetings she organised in the early I990s. "There were those who didn't want to join the marriage of patriarchy," she said, and she remembered that one of the arguments was: "We won't let ourselves be pushed into marriage like heterosexuals, like sheep!" ${ }^{2}$

A major change in the social situation for homosexuals came with the AIDS crisis in the I980s. It had far-reaching consequences for the entire gay and lesbian community. One of its effects was that it contributed to separatism and made lesbians even less inclined to support a male project of getting a law on registered partnership, a situation diametrically opposite to that in the United States, where the AIDS crisis resulted in closer ties between lesbians and gay men. ${ }^{33}$

\section{Women and AIDS}

Women had been present as a minority within the Scandinavian homophile movement ever since it started and constantly had to fight against invisibility and male domination. According to Else Slange, many women were members of the national gay and lesbian organisation, the LBL, in the r980s, but they were invisible and needed to be motivated by issues that concerned them. As an example of how women could be mobilised in the movement if they felt that something concerned them, Slange mentioned paedophilia. A paedophile group had become affiliated with the LBL in I983, and in 1985 some lesbian members moved to have it excluded. However, the LBL General Assembly decided that it could remain within the organisation. Most women present at the meeting voted for exclusion, but they were in the minority. They then demanded an extraordinary general assembly and asked all women members of LBL to come. A large number of women showed up and managed to overturn the previous decision. ${ }^{34}$ This event proved to be the beginning of a lesbian renaissance in the Danish movement, a development that contrasted with the other Scandinavian gay rights movements, where women were more marginalised.

In the other Nordic countries, the AIDS epidemic further alienated women from the movement and led to the strengthening of separate lesbian groups. Porvaldur Kristinsson had just become chairman of The Society of 1978 when AIDS struck Iceland. He remembers how lesbians left the movement when all efforts focused on AIDS and men's sexuality. "What happened here was, as far as I understand, somewhat opposite to what happened in the States, where the AIDS crisis brought men and women together. Women here complained repeatedly about being left behind. They didn't participate, they couldn't involve 
themselves in the AIDS work. They didn't experience the fear and desperation that we did." ${ }_{55}$ Lana Kolbrún Eddudóttir, who worked actively with AIDS prevention, remembers that many women were active. But it was also a question of taking space in the movement. "The guys had to accept that the girls took up more space. And they were needed to keep up the work. We were supposed to cooperate, weren't we?"36

Scandinavian lesbians were indeed divided on this issue. Many of their gay friends fell ill and died, and many lesbians were profoundly grief-stricken, but many were also disappointed that this happened at the exact moment they had managed to get a stronger position in the movement and had forced it to give more time and space to lesbians. When AIDS hit Scandinavia, all attention and all money and energy were once more directed to gay men. Terhi Saarinen remembers the situation in Finland: "We women were not so interested in AIDS. It wasn't our problem . . . Some lesbians thought we should be with gay men, because the times were so hard. But there were others, like me, who of course were sad but thought there were other things that were more important for lesbians." ${ }^{77}$ One explanation for the difference between Scandinavian and U.S. lesbians' response to the AIDS epidemic may be that Scandinavia had more developed public health programmes, and the need for voluntary work was consequently less accentuated. Governmental response to the AIDS crisis differed among the Scandinavian countries, but the general health care systems were solid, and all over Scandinavia government funding was channelled into the gay and lesbian movements.

One woman who worked with AIDS in Sweden was Anna Mohr. In an interview she remembered how tired she was of being questioned and criticised by both sides: "I often felt it was difficult to work as a woman among all these men with their super-male jargon and very little interest in women's questions. I had to work like hell here [in the RFSL Centre]. And then I was constantly called in question by the women's movement." There were, according to Mohr, two groups of lesbians in the I980s: those active in the lesbian and gay movement, who felt that AIDS was a very important question, and those more interested in social activities, who thought that men's issues were taking over. "They saw that the guys got loads of money. There were loads of safe-sex information for guys. There were dicks on every wall and there were so many condoms and so much male sexuality that you felt like throwing up. ${ }^{38}$ At this time many women felt marginalised in the Swedish lesbian and gay movement and left and founded the group Lesbisk Nu! (Lesbian Now!). The same thing happened in Finland, where lesbians formed the separate group Akanat (Chaff), and in Iceland, where disgruntled lesbians gathered in the group Íslensk lesbiska (Icelandic Lesbians). In Norway, where the AIDS prevention work was managed by a separate group, independent from the two existing national organisations, there was less ten- 
sion between men and women, and in Denmark women had a stronger position within the LBL. 39

The wedge that AIDS forced between gays and lesbians in Scandinavia further accentuated the differences between their respective goals and priorities. If the men had never thought much about feminist issues, most women did not care much for male sexuality and their health problems. This was a contributing cause why many lesbians felt alienated from the project of registered partnership in the r980s and left it to gay men to do the fighting. As mentioned, women took their place in the Danish gay and lesbian movement in the early I980s when they mobilised against paedophilia. In the other Nordic countries, however, the I980s were a time of separate lesbian organisations, and it wasn't until the I990s that women began exerting as much influence as men in the national gay and lesbian organisations.

\section{Radical male resistance}

If the feminist argument against gay marriage or registered partnership was based in a materialist critique of patriarchy, radical gay men's standpoint focused on the capitalist modes of production and the crippling mechanisms of a homophobic environment. Inspired by Wilhelm Reich, they wanted to combine a Marxist world view with psychoanalytic insights and hailed sexuality as the most important force in society. Sometimes their criticism was less articulate, and often the hippie slogan "make love not war" gave voice to more diffuse discontents with modern society. For many of the groups that were formed in the waves of gay radicalism in the I970s the process of creating a positive identity was the main priority. Wilhelm von Rosen, who was active in the Danish Gay Men's Liberation Front, BBF (Bøssernes Befrielses Front), between 1973 and I977, explained in an interview: "The crucial question was the identity formation of homosexuals, the self-consciousness of the gay men themselves. That is, the struggle against self-hatred and a conception of oneself that is perhaps hard to understand now, almost half a century later." The question of gay marriage or registered partnership was not an issue for the members of BBF. Wilhelm von Rosen remembers that they were not the least interested in registered partnership and watched the work for it "with a certain indifference and friendly interest," because the arena in which that struggle took place was so far away from the one where BBF wanted to work. When asked, he admits that some members were in fact against the law on ideological grounds: "They thought it was a bad thing. It was imitating bourgeois marriage, which we shouldn't work for, because we were leftists and socialists and even communists in some cases."Von Rosen remembers the $\mathrm{BBF}$ as an organisation that was not primarily interested in changing society but in changing the negative self-images of homosexuals: 


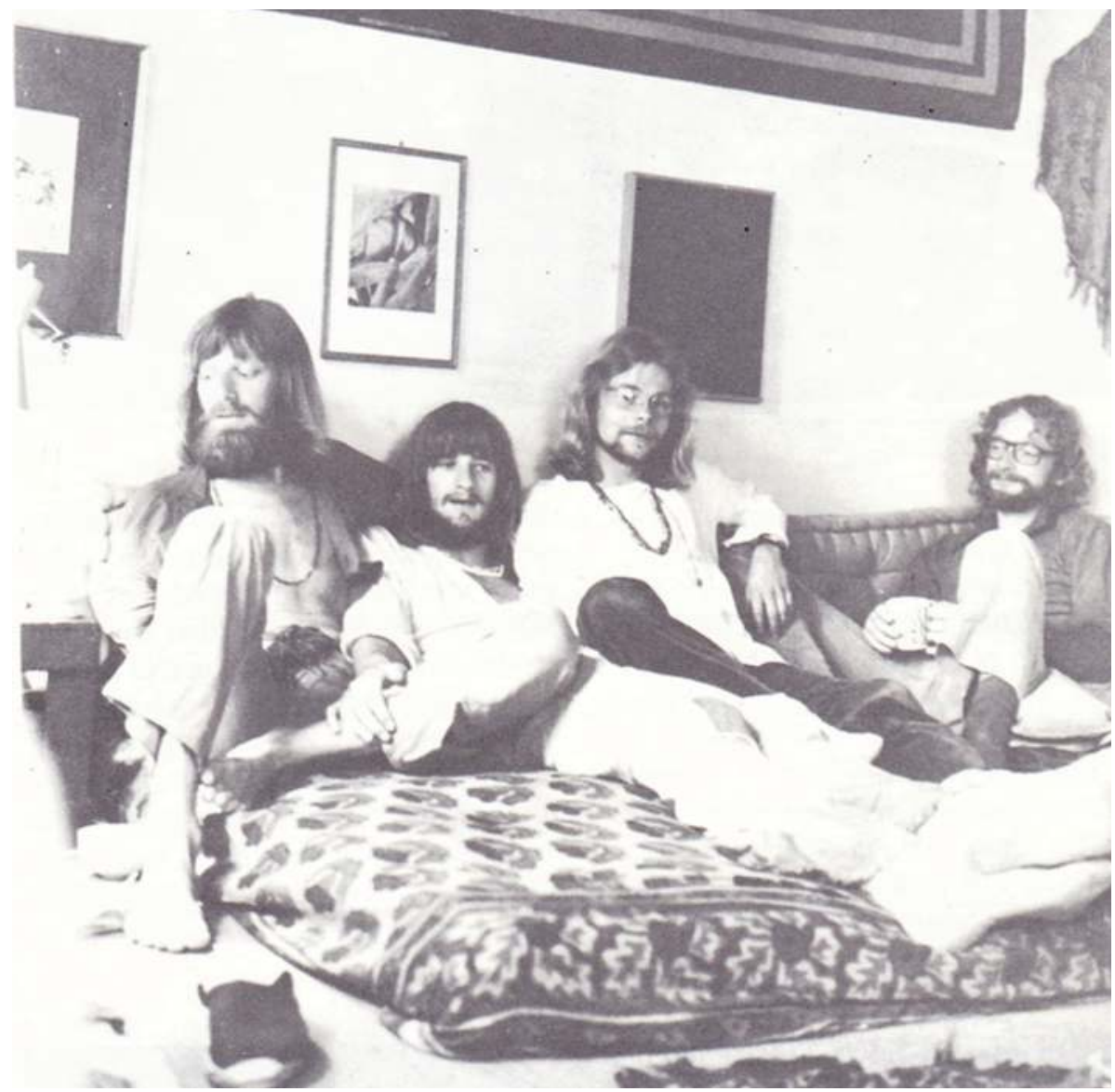

The members of the gay collective Stormly (Storm Shelter) in Copenhagen were utterly indifferent to the idea of registered partnership. From left to right: Finn Mikkelsen, Ole Rufus Nielsen, Ole Nørlyng, Wilhelm von Rosen. Source: PAN-bladet, Copenhagen, no. 6 (1972).

First and foremost we wanted to change the homosexuals themselves. That was our primary task. Of course we wanted to change the heterosexuals also, but we just told them brutally what we thought of them, that they oppressed us, that they were awful, that their lifestyle was appalling, and that we thought of them as enemies. It couldn't be any other way. And if they thought we exaggerated, we couldn't care less..$^{\circ}$

There were other groups who were more focused on social change but still gave priority to consciousness-raising. The more politically articulate fraction of the gay radicals argued that a social revolution was not possible without a sexual revolution. In an article from 2000, suffused with self-irony, Swedish gay activist Greger Eman has described how he and his friends went out into the gay men's 
cruising park in Göteborg in the early I970s in order to inspire and politicise the "homosexual proletariat." They lit a bonfire and offered salad to the cruising men. "What surprises me in retrospect is that I can't remember getting any negative comments from the passers-by," Eman wrote. "The men smiled shyly and accepted the salad. They were friendly but refused to 'come out of the bushes' and join us on our blanket in singing [the feminist song] 'Liberation is near."' 4 '

As Lana Kolbrún remembers it, Icelandic men opposed the law from both political conviction and personal experience. "The guys thought it was the stupidest thing we could do [to work for the law]." But she chooses to understand it most of all from a psychological perspective. "You have to understand our feelings. Most of us, the older generation who are forty now, were rejected by our own families. And I think some of us were so hurt that they didn't want to ... do like everybody else. They didn't want to be normalised." ${ }^{42}$

In the radical struggle to change the world lies a dilemma that will surface as soon as a group works politically for recognition. First of all, the radical gays and lesbians wanted to change society before they became an integral part of it, but they also needed recognition from the society in which they lived there and then. That dual ambition was the reason they sought and found their foremost political allies among the socialist parties to the left of the Social Democrats. Most of those parties were no longer revolutionary in a Marxist sense, but they worked for a more profound change of society than the reformist Social Democrats, and to the extent they had got rid of their Stalinist heritage, they were also prepared to listen to the demands for gay and lesbian rights.

\section{The right to be different}

Another activists' argument against gay marriage was the insistence that gay and lesbian diversity would be threatened by a normalising law such as the law on registered partnership. This cultural argument was generally weak or not articulated at all before queer theory questioned heteronormativity in the 1990s. But when the Danish law was on its way, it sparked a discussion within the movement that shows that the diversity argument was being developed during this time. In I988, Sanne Yde Schmidt, a lesbian activist of LBL, summarised the argument for the Nordic Council for Homosexuals or NRH (Nordisk Råd for Homoseksuelle) and the International Gay and lesbian Association, ILGA. ${ }^{43}$ In a document sent out for discussion, she mentioned that a debate had emerged in Denmark about the objectives of the gay and lesbian movement when the law on registered partnership was being prepared. Much of the debate focused on identity. "The question is whether it is possible to resist being discriminated against (the fact that we are treated differently) without giving up the idea that we are (and have the right to be) different." When Danish gays and lesbians tried to describe their personal visions of what life would be in twenty years, she 
said, they mainly emphasised visibility - to be visible in society and depicted in the arts. If gays and lesbians were visible, it would be difficult to find reasons to deny them basic freedoms. "The problem is not whether we wish to be accepted. That is necessary for us. The problem is whether we want to be accepted as a lifestyle similar to the heterosexual (except for some minor details), or whether we want to be accepted as an equal but different culture." She concluded her discussion paper saying that both things were necessary: to point out the likeness between homo- and heterosexual cultures, and to "maintain and develop our gay/lesbian cultures." 44

The argument here seems to be aimed at those who opposed the partnership law and not at those who actually worked for it. But the fact is, there was a general consensus on many levels that imitating heterosexual marriage was below the dignity of gays and lesbians. And there was an even stronger consensus that a separate law on partnership for same-sex couples was unacceptable. Instead of being singled out in a special law, many gay and some lesbian activists wanted to have the whole loaf and not just crumbs. As the situation in Sweden clearly shows, this strong consensus, however, quickly vanished as the Danish law became reality.

\section{All or nothing}

Before the Danish partnership law was adopted, none of the Swedish gay and lesbian groups accepted the "registration according to a separate order" (registrering i särskild ordning) proposed by the Swedish Government's Homo Commission. Anna Mohr later recalled opposition to this proposal: "All the organisations, as far as I can remember, were unanimously - and without even reflecting on it as an alternative - against a separate order of registration . . . And it was a matter of course that we did not want a separate legislation in any way." ${ }^{4}$ When the Homo Commission sent out a document in I98I, asking for opinions on possible forms for the legal regulation of same-sex couples, the condemnation of a separate legislation for gay and lesbian couples was unanimous. The RFSL wrote: "The alternative implies, in fact, that a separate set of rules will be introduced for homosexual relations, which must be interpreted as discriminatory." The RFSL could only accept such a solution if the registration was also to be open for heterosexual couples (the way it later became in the Netherlands and France). ${ }^{46}$ The political lobby group Homosexual Socialists (Homosexuella Socialister), consisting of both organised Social Democrats and Communists, was harsher in its criticism. It categorically rejected "all forms of separate legislation for homosexuals" because it had discrimination as a built-in consequence. "We think it is dishonest that the 'registered marriage' is described as something other than a B-marriage, a surrogate that can become better or worse depending on the possible benevolence of the legislator." 47 A third group that sent in 
its comments to the proposal, the Ecumenical Group for Christian Homosexuals, EKHO (Ekumeniska gruppen för kristna homosexuella), was also negative. The only acceptable form for registration of homosexual couples would be that all marriages were supplemented with an "act of notification or registration" in the presence of witnesses. A separate registration would result in discrimination and "preservation of prejudice," they wrote. ${ }^{4}$ Finally, the earlier mentioned group Lesbian Feminists, or LF, dismissed the thought of marriage altogether. The nuclear family in patriarchal society, they argued, reduced women to "dependency, passivity, sacrifice, and lack of identity." Lesbian Feminists could not support a proposal merely allowing homosexuals to live in that form, and they strongly rejected the idea that homosexuals were to be "squeezed into marriage" by a law on separate registration. ${ }^{49}$ These examples from various parts of the gay and lesbian movement in Sweden show that the rejection of the idea of a separate legislation for same-sex relations was unanimous in the r980s.

These reservations were put aside when the Danish law was adopted and some form of law regulation of same-sex relations seemed politically possible, but since all Scandinavian movements were against separate legislation for homosexuals, the Danes called the partnership registrations marriages, even though they were not. The Danish gay and lesbian movement repeatedly told the world media that Denmark was the first country in the world where homosexuals were allowed to marry, omitting that this was not an actual marriage and that there were restrictions. In an interview, Tobias Wikström commented on this use of the language: "It was naturally in order to get the most out of a happy landmark victory, but it also has a political tactical twist: They try to call it something diminutive, but we call it 'getting married." However, when the interview was made, ten years after the registered partnership had been adopted in Sweden, but before the gender-neutral marriage law had been adopted, Wikström's use of the language had changed accordingly. "Now I wouldn't call it 'getting married," he said, "because now we fight for a real gender-neutral marriage." ${ }^{\circ}$

\section{Two activists}

Two voices may exemplify queer resistance to marriage laws for homosexuals in the I970s and I980s: Karen-Christine "Kim" Friele, chair of the Norwegian gay and lesbian movement DNF ' 48 from 1967 to 1972, its Secretary General from 1972 to 1989 , and thereafter influential public figure and opinion maker, and Porvaldur Kristinsson, one of the leading figures in the Icelandic gay and lesbian movement from 1980 to the present. Following Norwegian and Icelandic custom, I will use Kim Friele's surname, and Porvaldur Kristinsson's first name when referring to them. 
Friele dominated the Norwegian gay and lesbian movement for decades and exerted a strong influence on gay and lesbian rights movements in all of Scandinavia, and Porvaldur has been a centrally placed gay activist during the paradigm shift, when Iceland quickly evolved from a homophobic to an explicitly gay-friendly society. Both of them were decidedly against the idea of civil unions for same-sex couples, Porvaldur for the reason that gays should not imitate heterosexual institutions, while Friele's arguments were more focused on the privilege it would give to couples at the expense of those who could not or would not live with a partner. It was not until later that she developed the argument that the registered partnership did not include children. When they were interviewed, Porvaldur discussed at length the reasons why he changed his mind and now endorsed registered partnership, whereas Friele explained that she had never changed her mind. She explained that she was always in favour of gay marriage, but not in the form it had been presented to the Norwegian Parliament in I993.

During the interview, Porvaldur mentioned that he became politically influenced in the early I980s by Bøssernes Befrielses Front (Gay Men's Liberation Front, BBF) in Denmark, as well as by his Danish lover and his circle of friends in Århus. Visibility then became a key concept for him. "I realised that visibility is actually the key to every answer. I was so convinced that our politics really was a simple thing, actually. As soon as you become visible to your surroundings, the prejudice will disappear. So I believed. I'm not so convinced anymore. But that was my conviction then." ${ }^{11}$ Although the BBF worked for visibility and public action, gay marriage was not on their agenda, and Porvaldur remained sceptical about it even when he, as chair of Samtökin '78, lobbied for an Icelandic Homo Commission. Ingibjörg Sólrun Gísladóttir from the Women's List presented the proposal in Parliament, and Porvaldur made much of the work behind it. "What I didn't fully realize then ... was the fact that the issue of registered partnership would become a central one in the work of that committee," he explained in later correspondence..$^{2}$ After the Danish law had come into existence, a law on registered partnership seemed the logical way to go for many, both within the gay and lesbian movements and in mainstream politics.

Porvaldur's conviction that visibility was the best strategy was to guide him as one of the leaders of the Icelandic gay and lesbian movement, and it was also the reason that he finally could accept the law on registered partnership. At first, though, he thought he could never accept such a law. "And the argument was very classical and actually banal. I didn't want to be integrated in a traditional heterosexual way. I shared this opinion with many of my friends abroad, in both Scandinavia and America, and I was pretty much influenced by American voices in gay publications. I was not aware then that their standpoint in this matter was somewhat different from mine. What they meant by marriage was something quite other than we saw in Scandinavia." 
During the interview, Porvaldur talked a lot about the distinctiveness of Nordic culture in general and Icelandic culture in particular. This may explain why Icelandic society has experienced the most extraordinary change in attitudes to homosexuality, he said. Porvaldur didn't provide any more arguments for his earlier resistance to the law, but he said he was happy he had kept his doubts to himself. Between 1993 and 1997 he quietly left the movement because he could not fight for something he did not believe in, but later he changed his mind radically and quickly. It happened when the law on registered partnership became effective in Iceland, on 27 June 1996 . He changed his opinion "because the law meant a certain kind of recognition ... And already, that day, I could see how people were changing. Self-oppressive behaviour was gradually ebbing away. It will never completely disappear, but my friends are not the same."

Porvaldur went to the reception in the City Theatre of Reykjavík on the night when the law on registered partnership became reality. The President of the Republic was there, and many other dignitaries. Porvaldur went reluctantly, not wanting to celebrate the passage of a law he had been opposed to, but what he saw at the reception made him change his mind. "I met the President and my old friends. I saw old guys in their sixties and seventies for the first time in their lives coming out, showing themselves in daylight, with prominent figures. I met several clergymen from the Icelandic National Church there, et cetera, et cetera. So I thought, okay, maybe that is the way to go."

The years after the law on registered partnership was introduced proved him right, Porvaldur said. During this time, Icelandic society has changed from a homophobic society to a country where it is a matter of national pride to be gayfriendly. According to Porvaldur, the importance of the family in such a small country cannot be overrated. Most families arrange big gatherings every second, third, or fourth year, and often several hundred people show up. "All families do this, more or less on a smaller or bigger scale. It's called attarmót, the meeting of the family, which means that people from four generations gather together, and it's mostly out in the country. Those meetings are a bit funny, but emotionally very important." So to be able to present a partner of the same sex at such a huge family gathering is very important to every Icelander, which in part explains why the formal state recognition of same-sex relationships means so much to a person in a small country, based to a great extent on family ties.

"I think," Porvaldur said, "that my old argument, which I fortunately kept to myself, was simply wrong, because I didn't take into account the special situation of Icelanders, which partly is similar to the whole of Scandinavia." Family ties are probably more important in small linguistic and cultural entities, and the acceptance of the family becomes more important than in larger countries. However, to marry, to register your partnership, Porvaldur contended, has only partly to do with imitating the rest of society: "You are always more or less imitating the others. We don't know who we are and are not!" 
Porvaldur expressed his satisfaction that he now realised gay marriage is still something completely different from a heteronormative marriage. "You can establish a family, you can register, you can form this kind of imitation of regular bourgeois marriage. This is, however, not the same thing." Several of Porvaldur's gay friends who registered a partnership have declared, more or less directly, that they live in open relationships, something that Porvaldur sees as hopeful for the queer lifestyle and for the diversity of mankind. "I think that humanity always finds its independent way to survive and seek happiness."

Porvaldur came back to gay and lesbian activism in 1997, after the partnership law had been adopted, and, as chair of Samtökin '78 in 2000-2005, he worked hard to extend the law to cover rainbow families. He worked for full adoption rights and access to assisted reproduction techniques "wholeheartedly, convinced that this was the right way to go, an important and necessary step toward one single marriage act." ${ }_{53}$ It was the visibility and public recognition of lesbians and gays that convinced Porvaldur that registered partnership and gay marriage were useful legal tools for gay and lesbian emancipation. Since his resignation in 2005, after his third term as chair of Samtökin '78, he has been dedicated to organising Reykjavík Gay Pride, the huge event he was involved in founding.

Kim Friele, a Norwegian lesbian activist who has had a great influence on Scandinavian gay and lesbian politics in the I970s and I980s, sees things differently. During her interview, she pointed out that it was false to claim that she had been against gay marriage. After all, the initiative in debating the partnership issue was hers already in 1973 when she summoned a meeting with the other Scandinavian movements and the Dutch COC, just to discuss gay marriage. After that, the Norwegian movement agreed to legal recognition of same-sex relations as long as they were not copying heterosexual marriage. In the I970s, however, the Norwegian movement chose not to focus on legalising domestic partnerships for same-sex couples, but lobbied instead for an anti-discrimination clause in the criminal code. ${ }^{54}$

In the late 1980s, the partnership issue became a cause of debate within the DNF' 48 , and a conflict sprang up between Friele and a generation of younger activists who were inspired by the Danish law and wanted to work for a similar law in Norway. Friele's arguments in that debate focused on her refusal to grant privileges to couples at the expense of single people or those who chose other kinds of relationships, and she also presented the feminist argument that there should be no mutual support law and no talk about a "weaker partner" in the relation. During the interview, Friele stressed again that she was never against the partnership law as such. The debate within the Scandinavian movements at the beginning of the ra7os focused on the question of giving privileges to couples and not to others. Then there was no debate about marriage for same-sex couples until I98I when Friele herself initiated work to formulate an alternative to 
the Government's proposal about household communities (busstandsfellesskap). Her speech at a general assembly of the $\mathrm{DNF}^{\prime} 48$ became a semi-official policy document. "My advice then to the national board was that we should work for legal regulation of the relations of gays and lesbians ... but I think that since we were not in a hurry we should critically evaluate it and see if the marriage law in practice has legal effects that are impossible for us to work for." ${ }_{55}$ She explained that she had great difficulty in accepting the partnership law as it had been formulated in Denmark, since "it didn't include the children." And she regarded it as a mistake that the movement accepted such a law. "I thought that we shouldn't be so keen on marriage that we couldn't wait until we got the children included." And today, Friele pointed out, "the partnership law is called a B-marriage by the same people who fought for it! But when I said so at the end of the 1980 os and the beginning of the r 990 os I was almost shot, wasn't I?" ${ }^{6}$ Toward the end of the interview, Friele turned to me and said: "Then you can say: Should we have waited ten more years? No, I guess not. But we should have been courageous and honest enough to have discussed it thoroughly within the gay movement." ${ }^{7}$ When the interview was conducted, in September 2005, the law on registered partnership had been in force for twelve years, but the Socialist Left Party had already presented a proposal to replace it by a gender-neutral marriage law. The proposal had failed, but Friele pointed out with some satisfaction that the gay activists now were working for something she had suggested from the very beginning.

In many ways, Friele's position demonstrates the dilemma facing gay and lesbian activism regarding integration in society. On the one hand, lesbians and gays strive for recognition, but on the other they resent assimilation. She admitted that the partnership law has worked well during its years of existence. But there is also another dimension to what she wants. "I think they are a bit stout, you see, the Norwegian gay and lesbian movement, with house and poodle and garden and ... There aren't any really controversial ideological gay political debates anymore. ${ }^{58}$

The two activists, Porvaldur Kristinsson and Kim Friele, were both reluctant to accept the idea of a gay marriage law that would emulate heterosexual marriage. Whereas Porvaldur seems to have leaned more toward a plea for diversity and sexual freedom, Friele emphasised the equality and solidarity argument. Both had to give in to strong political pressure, but whereas Porvaldur quietly distanced himself from the gay movement, Friele fought for and loudly defended what she believed in. ${ }^{59}$ The price she had to pay for her many conflicts with other activists was to become isolated from the Norwegian gay movement for a long period. However, a sort of reconciliation was reached when the Norwegian movement asked her and her partner to be among the first couples to register in Oslo City Hall and to be guests of honour at the ensuing wedding party. Friele mentioned that she has been criticised for registering her own part- 
nership by those who thought she betrayed the anti-partnership wing in the movement and by those who fought against her for the partnership law. "Many thought we were traitors. Many thought we had let them down by registering our partnership before the children were included in the law." Others thought it was strange that she changed sides so quickly. "And many others used the opposite argument. How can it be that you two, who were against the partnership law, can be so bold as to register your partnership?" Friele dismissed the second argument by claiming that she had never opposed gay marriage. To the others, she would say that she didn't think she and her partner had any obligation to be sacrificed for the sake of those with children. "And we said that this is how it is, and we have no children, but we have debts, and we have a house ... We'll do this. Now we shall cherish our love. And so we did."6o

\section{Conclusions}

The idea of gay marriage or separate registration of same-sex couples was thus supported by only a minority in the established gay and lesbian movement in each Scandinavian country. How could this minority prevail, in view of the radical stance of the reform movement throughout the ig8os? With typically liberal arguments about equality before the law, they did not score very high in the eyes of the more militant left forces in the gay and lesbian movement. Yet it was their agenda and their priorities that determined the course of Scandinavian gay and lesbian politics in the I980s and I990s. One reason for this was that they were well organised and that they spoke the same language as the authorities. Another reason was that the direct gains of the politics of visibility and assimilation were obvious and easy to point out to their members. The demands for gay marriage were easy to understand and represented a concrete political goal for those who wanted to support the gay cause. As we have seen, Norway chose another way in 1973 and gave priority to the work for an anti-discrimination clause. But that did not cause celebration, except when the clause was adopted by Parliament. It did not engender recurring scenes of marital joy, but lengthy trials in the court system, trials that were lost more often than not. The law on registered partnership was perfect for a society that wanted to mirror itself in its tolerance, and for a gay and lesbian community that wanted positive attention. The ceremonies that resulted from it constantly reminded all people of the happy outcome of their decision. Following the same logic, the public ceremony staged in Helsinki by SETA in I994, when four lesbian and gay couples performed "illegal" marriage ceremonies, was in itself a strong visual argument for registered partnership. To be able to deny the happy couples that joy, one had indeed to carry a strong conviction against it. The same can be said about the resistance to gay marriage within the movement. When the Norwegian movement made its decision in 1973 not to work for gay marriage, it was yet so far from becom- 
ing a reality that it was perceived as a rather abstract policy issue. But when the Danish partnership law was on its way, many lesbian feminists and radical gay activists who were against it could not bring themselves openly to oppose it. In this situation, perhaps the AIDS epidemic had some effect. Gay men were in deep crisis, and if marriage was what many gay men wanted, then the opponents within the movements may have withheld their opposition.

The most important aspect, however, was that liberal or social democratic, reformist gay men had the power in the national gay and lesbian movements in the I990s. Lesbian feminists whose ideological conviction differed significantly from the liberal pro-marriage stance chose to work in separate organisations, and those who remained in the national movements made compromises with the men.

In Denmark, Per Kleis Bønnelykke, who was chair of the LBL and a liberal politician, gave up his attempts to make the LBL work for registered partnership in the mid-r97os. His successor, Bent Hansen, worked in a changing political landscape. In 1983 he managed to achieve binding promises from gay-friendly political parties to work for a commission on the living conditions for homosexuals in society. For him and the other homosexual representatives in the Danish Homo Commission, registered partnership was a self-evident goal to work for. In Sweden, the radical leadership of the RFSL of the I970s was gradually becoming more bureaucratic. Stig-Åke Petersson, founder of the Swedish Gay Liberals, was RFSL's representative in the Swedish Homo Commission. For him, some form of gay marriage was a matter of equality.

The Norwegian movement did not work for registered partnership until the beginning of the I990s. The new chair, Kjell Erik Øie, was later elected to the Oslo Municipal Council for the Labour Party. Neither for him, nor for the many women who took an active part in the lobbying efforts, were the feminist and radical arguments valid anymore. There had been a paradigm shift, in which second-wave feminism had been considerably weakened, and theories of patriarchy were no longer important for lesbian women's political decisions. The gay and lesbian national organisations became professionalised in the r980s and developed channels to high-level politicians in each country. In Finland, the leadership of the gay and lesbian movement in the I980 consisted of social democratic and left socialist politicians, but registered partnership was so far from the political reality that it was never even on the agenda. In the I990s, the persistent opposition from the authorities helped unite the Finnish gay and lesbian movement in its demands for partnership. Iceland, finally, had such a small gay and lesbian movement that different opinions could hardly coexist within it. The lesbian separatist organisation was of limited size, and activists critical to gay marriage often chose not to question the movement's pro-partnership policy.

The success of the reformist politics of the Scandinavian lesbian and gay movements only became possible when there was enough positive response from 
the political establishment. When there were enough gay-friendly politicians on the parliamentary level, the liberals and reformist Social Democrats within the lesbian and gay movements were strengthened within their own ranks, and the radical feminists and those who advocated confrontational politics accordingly lost ground. In the next chapter, we will see how demands for lesbian and gay rights gained acceptance within the mainstream political system. 


\section{Chapter Three: \\ Gay marriage in mainstream politics}

During the twentieth century, the Scandinavian countries saw the establishment of a fairly stable five-party system following two basic divisions: that between work and capital and that between urban and rural interests. This led to the establishment of large workers' parties, large agrarian parties, and large conservative parties that defended the interests of the capital owners. Next to these three class-based party formations, smaller ideology-based parties evolved. The communist or left socialist parties on the one hand and the liberal parties on the other generally attracted between 5 and ro percent each of the voters. This stable five-party structure was challenged by the emergence of new political parties in the I970s and I980s. Radical right-wing parties were created as a reaction to high taxes. Christian parties were established or strengthened as a reaction to liberal abortion laws and the release of pornography. Finally, environmentalist or Green parties became established in Finland and Sweden. The right-wing populist parties generally had a neo-liberal agenda and as such they sometimes had a positive stance on gay and lesbian rights issues. However, strong reactionary forces - and a macho leadership - within these parties eventually led to a homophobic attitude. ${ }^{\mathrm{I}}$ The position of the green parties in the political spectrum was initially unclear, but for the most part they consisted of younger people who, when asked, would be in favour of gay and lesbian rights. The Christian democratic parties, finally, were consistently opposed to such rights, since they had been created by conservative Christians to defend traditional values. ${ }^{2}$

In the late sixties and early seventies, political work for same-sex relationship regulation began in the smaller ideological parties, the left socialist or liberal parties. The larger parties were either opposed to gay and lesbian rights (like the conservative and centre parties) or uninterested or split over the issue (like the social democrats). It is important to remember, however, that this picture is simplified, since no party was unanimous in its support for, or resistance to, gay and lesbian rights. In Sweden, there was an important presence of Christian freethinkers in the People's Party before the Christian Democratic Party managed to attract most of them. They were generally opposed to gay and lesbian rights and when their influence in the liberal People's Party diminished, its commitment to gay and lesbian rights issues grew stronger. Likewise, the acceptance of 
sexual minorities in the left socialist parties was adversely proportional to the presence of Moscow-oriented old-timers. ${ }^{3}$

\section{Left socialist parties and the leftist response to gay marriage}

The I950s and I96os saw the creation of new socialist parties to the left of the Social Democrats, parties that broke with either the Moscow-influenced Communist hardliners or the Social Democrats and could therefore harbour pro-gay standpoints in a more libertarian socialist tradition.

As we have seen, it was the Danish Socialist People's Party, SF, that in 1968 was the first to take the initiative in regulating same-sex relations, but it should be pointed out that this was part of a larger proposal to help both same-sex and different-sex couples register their relationships, to create a possibility for groups to register their relationship, and to allow siblings to marry. The proposal stirred some debate, and some newspapers described it as opening the road to harems, polygamy, incest and moral decay. All in all, the debate in Parliament was held in a cautiously positive tone, and more than one speaker specifically welcomed the provision for same-sex couples to regulate their relationship. In concluding the parliamentary debate, SF's leader Poul Dam thanked the speakers for constructive comments, and he said he did not believe that the law, if it were adopted, would lead to higher numbers of homosexual couples. "But I think that those that really exist will get a better, a more humane life, if society tells them that 'yes, we know you are there, we not only tolerate you, but we also see that you have certain problems that we would like to help you solve by legislation."' 4 This liberal and understanding attitude contrasts sharply with the homophobic campaigns just a decade earlier, but it is also an example of a benevolent speech concerning tolerance and help instead of rights. The gay and lesbian movement had not yet developed a radical stance and had not yet the power to influence the general debate to any significant degree.

In the proposal that the Swedish Left Communist Party (VPK) presented five years later, the part about communal living had been toned down. "The state should recognise the existence of such forms of cohabitation but not legally regulate them" was their standpoint. ${ }^{5}$ The Standing Law Committee dealt rather favourably with the Left Communist Party's motion. It rejected its proposal but acknowledged the need to deal with the situation of homosexuals, and it wrote in its report that "a love relation between two persons of the same sex is from the point of view of society a fully acceptable form of coexistence." ${ }^{\prime}$ As in Denmark five years earlier, the debate in Parliament was generous, and there was remarkably little opposition to the suggestion that same-sex relations were "fully acceptable."

Like its sister parties in Denmark and Sweden, the Norwegian Socialist Left Party (Sosialistisk Venstreparti) was the closest ally to DNF' 48 in Parlia- 
ment during the I970s and took several initiatives in questions of lesbian and gay rights. ${ }^{8}$ Since the lesbian and gay movement had clearly declared that it did not want gay marriage, it did not present any marriage-law proposals to the Storting, but worked instead for a clause against discrimination on grounds of sexual orientation.

As earlier mentioned, most of the leading lesbian and gay activists in Norway sympathised either with the Socialist Left Party or with the AKP $(m-1)$. But whereas the Socialist Left Party had no problems in combining a socialist position with a pro-gay stance, the AKP strived to integrate its views on homosexuality in a Marxist-Leninist understanding of history and society. In its "Declaration on homosexuality," the AKP said that class was a more important aspect of the struggle for justice than sexual orientation:

As communists and revolutionaries we declare that class solidarity, and one's position in the class struggle, is more important than one's sexual orientation. In order to evaluate the position of homosexuals in society, it is therefore necessary to take the class conditions as a point of departure.... At the same time, the Party does not want to press homosexuals to change their orientation. Only a scientific analysis on the basis of Marxist-Leninist Mao Tse-tung's thoughts, and knowledge based on will and commitment, can fully solve the contradictions in this area. ${ }^{9}$

The quote illustrates the dilemma that left political organisations have faced in all questions related to minority group rights. Just as the women in the early workers' movements were expected to give priority to the men's political struggle instead of the work for women's right to vote, so the Norwegian lesbian and gay Marxist-Leninists must acknowledge the precedence of the class struggle. Lesbian and gay members of the AKP were torn between their political conviction and their desire to support the rights of sexual minorities. They were often successful in creating understanding for homosexuality within the party, but a self-critical document from I98I described how the party's gay political work systematically was purged of "everything that smacked of 'women's separatism,' homo chauvinism,' 'political lesbianism,' and 'humour." "го From i981, however, the AKP changed its political line concerning homosexuality and became decidedly gay friendly. Since then, its daily newspaper Klassekampen has been a forum for positive discussions about homosexuality. The homopolitical shift of position of the AKP in I98I paved the way for a reconciliation between the party and the various lesbian and gay movements in Norway, and in 1982 the exclusion of Marxist-Leninist members of the DNF' 48 was lifted. ${ }^{\text {II }}$

To a large extent, thanks to Jorma Hentilä, who was Party Secretary from I977 to I983, the Finnish SKDL/DFFF took a decisively pro-gay stand. Hentilä was not open to the public about his homosexuality when he became Party Secretary, but later he came out publicly as a gay man. In an interview for a 
Swedish lesbian and gay publication in 1989, he regretted that he had not been more open, "but the situation in Finnish society was different back then. The Jeremy Thorpe scandal had occurred in England, and he had been forced to resign because of his contacts with a male prostitute. I thought that people could have referred to that if I had been open." ${ }^{\text {I2 }}$ Most of the people around him, including the party leadership, knew he was gay long before. From i968, he lived in a steady relationship with Max Rand, who was a journalist for the national public radio and also for Finland's largest daily, Helsingin Sanomat. This meant that most Helsinki journalists and many politicians from various groups knew that the Party Secretary of one of Finland's largest political parties was gay, but they refrained from writing about it. Hentilä became chair of SETA in I983. By then he had already worked for a long time behind the scenes for lesbian and gay rights. ${ }^{\mathrm{I} 3}$ The Finnish Communist Party (Suomen Kommunistinen Puolue/ Finlands Kommunistiska Parti), which formed part of the SKDL/DFFF, organised the Moscow-oriented hardliners and did not sympathise with gay rights, but the larger organisation supported all initiatives to improve the legal situation for lesbians and gays.

In I98I when the left socialist gay lobby group "Left Homo" (Vasenhomo / Vänster-Homosexuella) was allowed to take part in the People's Democrats' May Day March under its own banner, its leader, Bengt Lindblom, complained in an interview that this had only been possible after long discussions, and he said he wished the SKDL/DFFF would take the same position as the Swedish VPK, which had worked actively for gay and lesbian rights for a long time. ${ }^{\mathrm{I}}$ This incident showed the limits of pro-gay politics in Finland at that time, and the impatience among many gay activists. In the interview, Hentilä said that there was, on the whole, support from the party leadership when they learned about his homosexuality, but he admits there were some negative reactions in the party in the early I980s. "When I became a Party Secretary, the ones who elected me knew I was a homosexual. But when I became chairperson [in SETA] there were some negative reactions from party comrades. Some people in the districts wanted to write protest letters to the chairman of the party." 15

In Iceland, it is difficult to determine where the political parties stood on gay and lesbian rights issues, since they were not part of the political agenda until fairly recently. Kristín S. Kvaran, who presented the proposal for pro-gay legislation in 1985, represented the small Social Democratic splinter party, The Socialist Alliance (Bandalagjafnadarmanna). ${ }^{16}$ Once the Women's List became interested in lesbian and gay issues, they were reliable as an ally to the lesbian and gay movement. Ingibjörg Sólrun Gísladóttir was its leader, and she was also editor of the feminist journal Vera. Through her editorial job, she began to be interested in lesbian and gay issues and wanted to bring them up in Parliament, "because there was a clear connection between women's liberation and the struggle that homosexuals waged for their rights. It was a struggle for human rights 
and I felt there was a strong connection between these things." ${ }^{\text {"7 }}$ Throughout the I990s, the Women's List and the People's Alliance were the foremost supporters of gay and lesbian rights, and it is fair to say that the adoption of the law on registered partnership in Iceland was due mainly to their initiative..$^{18}$ As we have seen, there is now a general consensus in all parties that lesbian and gay rights are important, though the parties on the left have more often taken the initiative. In 2002 Jóhanna Sigurðardóttir, leader of the United Left Party (Samfylkingin), which is a fusion of the Social Democrats, the Women's List, and the People's Alliance, registered her partnership with Jónína Leósdóttir, an Icelandic author and playwright. She was openly lesbian long before she became Prime Minister in 2009. ${ }^{19}$

In Greenland as well, it was the political left that supported gay and lesbian rights. It was an initiative from socialist Inuit Ataqatigiit's (IA) Minister of Social Affairs, Henriette Rasmussen, that brought about the introduction of the law on registered partnership. Moreover, as long as the gay and lesbian organisation Qaamaneq existed (2002-2007), another MP from IA, Asii Chemnitz Narup, served as its official protector. All in all, it is the left socialist IA that most consistently has worked for lesbian and gay rights in Greenland. ${ }^{\circ}$

In the Faroes, finally, where explicit political resistance to lesbian and gay rights has blocked the introduction of the law on registered partnership, all parties are split on lesbian and gay rights issues. The legal initiatives to introduce an anti-discrimination law, however, came from Social Democratic MP John Johannesen and Finnur Helmsdal from the Republican Party (Tjótveldi). The Leader of the Republican Party, Høgni Hoydal, has repeatedly declared that he is in favour of the registered partnership, but at present it is impossible to introduce the bill without breaking up the coalition Government. ${ }^{2 \mathrm{~T}}$

The Scandinavian left has been far from unanimous in its pro-gay stand. The Swedish Communist Marxist-Leninist Union (revolutionaries) (Kommunistiska Förbundet Marxist-Leninisterna [revolutionärerna], KFML[r]), was an orthodox Marxist-Leninist faction that later changed its name to the Communist Marxist-Leninist Party (KPML) and began participating in elections. In 1973 the party received a questionnaire from the RFSL regarding their views on homosexuality. In a scathing article an anonymous member of KFML(r)'s Politbureau dismissed homosexuality as "an unnatural phenomenon that stems from particular social conditions" (emphasis in original). The author's explanation for homosexuality was that the oppression of women under capitalism led to a widespread disdain for women among men, which many times resulted in men wanting to have sex only with men. (The author did not comment on the existence of female homosexuality.) That was not enough, however, for homosexuality to spread. It was mainly in societies that were "doomed to extinction" that homosexuality could thrive, and it had to do with the widespread pessimism in those societies: 
The rising class of our times, the modern proletariat, the class that is bearer of the future, the class that will overthrow capitalism and build socialism on its ruins, the class that will finally deliver humanity from exploitation, war, and oppression, and guarantee a rich material and cultural life for all, rejects with contempt the bourgeois quasi-scientists, who exalt what is natural for their own degenerate class and their own doomed society to something universal and natural.

All the questions asked by RFSL got negative answers, and the KFML(r) spokesperson added one question: "Can homosexuals obtain membership in the KFML(r)?”'The answer to that was also no. ${ }^{22}$

This article sparked a debate within the revolutionary left. Many organised lesbians and gays sympathised with movements on the far left, so the categorical dismissal of homosexuals as members of the Marxist-Leninist organisation was provoking, but there were also others who reacted. In a long article, KFML(r) member Thomas Bibin sharply criticised the argument that heterosexuality was more natural than homosexuality because heterosexual intercourse led to more babies. With quotations from Darwin, Kinsey, Lenin, Marx, Engels, and Bebel, he demonstrated that the author of the original article had lapsed into idealism, and he also criticised the author for setting aside the democratic centralism in the party. Without consulting the members, the author had issued new directives about membership. Moreover, he had "publicly defended the idealism presented in the article." Bibin claimed that homosexuality, like all sexual politics, must be of secondary importance to the revolutionary left, but since the question had been raised, he sharply criticised the way it had been dismissed. Why, he asked, did not the KFML(r) leadership analyse "RFSL and its self-absorbed reform struggle in the name of legalism, a reform struggle that not so much as glances at the fact that we live in a class society?" Finally, Bibin demanded that KFML(r)'s Politbureau "denounce the articles in our press and undertake thorough self-criticism for the attitude they have expressed." ${ }_{23}$

This discussion once again shows the dilemma of the political left at the time. Sexuality and gender issues were generally regarded as being of secondary importance, and when they surfaced it was generally assumed that oppression of women and homosexuality were social evils that would disappear in a future classless society.

\section{Liberal parties: A split electorate}

The standpoint of the liberal parties in Scandinavia seems to depend to a large extent on the strength of rural and/or Christian groups within the parties. The Danish Radical Left Party, a classical liberal party with an urban electorate, had already taken up gay and lesbian issues in the sixties, and its MP Else-Merete 
Ross consistently worked for gay and lesbian rights within the Danish Parliament. ${ }^{24}$ The Norwegian Left Party (Venstre) is a classical liberal party with an urban electorate. It was influential until it was almost annihilated in connection with the EU membership referendum in 1972 . It had a positive stand on gay and lesbian issues but was far from significant when the partnership debate began in the early I990s. ${ }^{25}$

In Sweden and Finland, the liberal parties were split over partnership for same-sex couples. The main divide in Sweden was between the so-called urban liberals and the "free-thinkers" (frisinnade), who stemmed from a free-church movement that fought state-church fundamentalism in the late nineteenth century. At the Party Congress in 1990, the question came to a head when a majority of congress representatives passed a mandatory resolution requesting that the party's MPs work for registered partnership for homosexual couples. In the parliamentary elections of I99I, the People's Party shrank from I2 to 9 percent of the votes, and the Christian Democrats grew from 3 to 7 percent. These changes were only partly because of the controversies over gay and lesbian rights, but they were definitely the result of many Christian voters' leaving the People's Party to join the Christian Democrats. According to MP Barbro Westerholm, this made it easier to work for gay and lesbian rights within the People's Party, and further concentrated the resistance to gay and lesbian rights in the Christian Democratic Party. ${ }^{26}$

During the postwar period, the Finnish Liberal People's Party (Liberaalinen Kansanpuolue, LKP / Liberala Folkpartiet, LFP) had between 4 and 8 percent of the votes until the elections in 1983 , when it virtually disappeared from the political scene. Before that, gay and lesbian issues were not part of mainstream politics in Finland, so it is hard to say what their stand on these questions might have been. ${ }^{27}$ The Swedish People's Party (Svenska Folkpartiet, SFP / Ruotsalainen Kansanpuolue, RKP), however, which represents the interests of the Swedish-speaking minority in Finland, has a largely liberal agenda. The SFP has between 4 and 5 percent of the electorate, but by representing an important part of the Swedish-speaking minority, its political influence is larger than its limited electorate would imply. The Party Congress in 1996 requested that the SFP representatives in Parliament and Government work for registered partnership for homosexuals, but at the Party Congress in 1999, several candidates from the rural province of Österbotten (Pohjanmaa) demanded that this decision be revoked. The tensions in the SFP did not follow religious lines but regional ones and there was largely a split between urban and rural liberals..$^{28}$

\section{Social Democrats: $A$ slow process}

In the rig6os and I970s, Scandinavian Social Democrats were opposed to or indifferent to gay and lesbian rights, but toward the end of the Ig6os there was an 
opening toward feminist issues due to the radicalisation of the feminist movement. In 1967, the Danish Social Democrats appointed a working party on family politics. The discussion document they sent out in I969 was radical, especially in its definition of family: "By family is understood a group consisting of adult people with or without children. (Extended families and homophile marriages are thus included in this concept of family.)"The document demanded that society take a far-reaching responsibility for the safety and well-being of the family unit, first and foremost by building more day-care centres, but also by protecting the rights of children. ${ }^{29}$ In I974, the Women's League of the Swedish Social Democratic Party followed suit and published a pamphlet on "Family Politics in the Future" which stirred some debate at the Party Congress. The booklet demanded full equality for women in the work market, extensive development of day-care facilities, and a reformed marriage law. Existing family laws should be part of a number of new "cohabitation laws" (samlernadslagstiftning), based on a view of the family as a voluntary union of economically independent members. The booklet pointed out that many groups remained outside the scope of traditional marriage legislation: "extended families, sibling households, homosexuals, and others." A new legislation would define the family differently: "By family we thus mean all forms of cohabitation of two or more individuals." One of its illustrations showed a man asking a woman, "Do you want to register with me?" Many delegates found the proposals too radical, but they had the support of the party leadership, including party leader Olof Palme and child psychologist Lisbet Palme, who played an important role in influencing the Social Democratic Party's feminist stand..$^{\circ}$

Lesbian and gay rights were not a prioritised issue in the workers' movements, but during the I980s there was a slow shift of opinion within the Scandinavian Social Democratic parties concerning these questions, often because of the initiative of their youth leagues. In Denmark, the Social Democrats were won for the cause already in the I980s, when the balance in Parliament made it convenient for them to seek alliances with the smaller socialist parties. The left socialist parties' pronounced stance in favour of lesbian and gay rights influenced the Social Democrats, and internal pressure from gay and lesbian party members also had an effect. In Norway a small group of young Social Democrats managed to swing opinion within the party in the beginning of the I99os, and in Sweden at the same time it was the grass roots members who forced the Social Democratic leadership to work for a law on registered partnership.

The person who was chosen to prepare the partnership issue in Denmark was Pia Gjellerup, who was elected to the Folketing in 1987 as one of the younger Social Democratic MPs. When interviewed, she emphasised that it was natural that the Social Democratic Party promoted registered partnership, "because it ... was about minorities and rights." When the proposal was presented to the Folketing, the Social Democratic Party was the first party behind the bill. "And I 


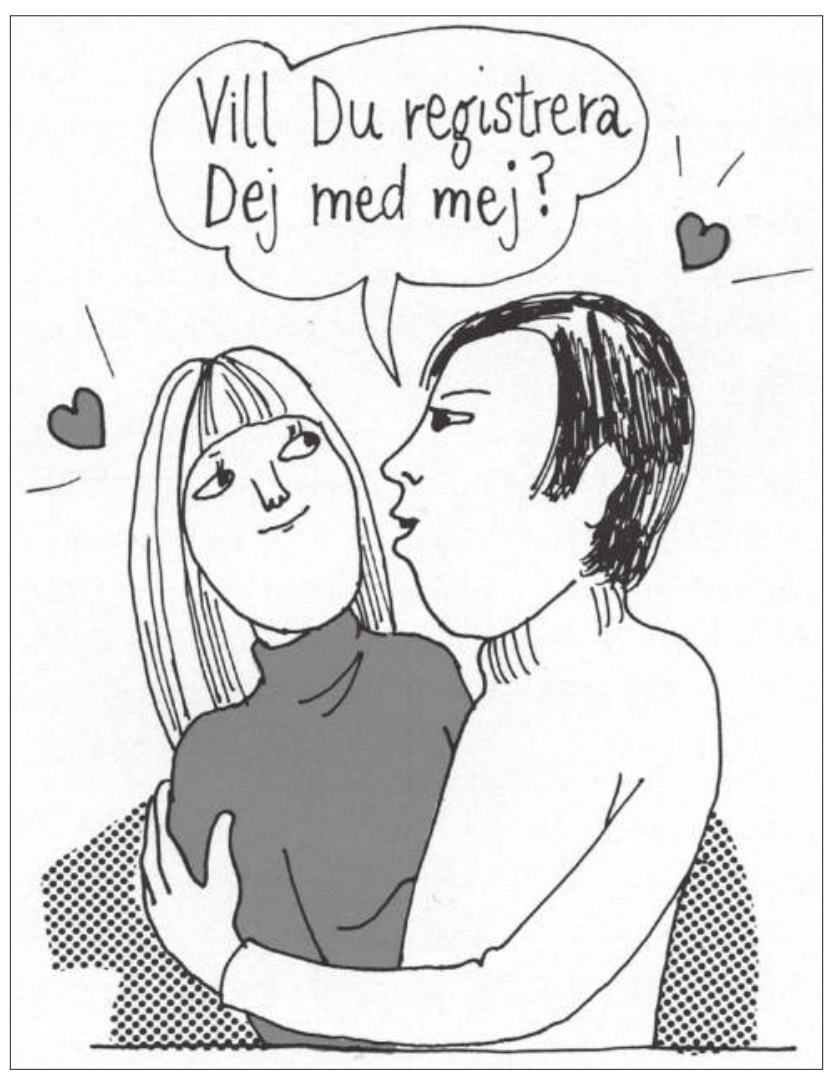

"Do you want to register with me?" The Swedish Social Democratic Women's League presented a radical programme for family politics to the Party Congress in 1972. Drawing: Katarina Erlandsson-Ribrant. Familjen i framtiden, 5th edition (1978).

have thought of this as 'when the big old party finally decides to do something, then things indeed begin to get done." ${ }^{\mathrm{I}}$ There was some resistance within the party, Gjellerup admitted, but it was marginal. What was crucial for promoting the cause in Denmark was the opinion poll in 1988, which showed that a majority of the Danes were in favour of a law on registered partnership. "It doesn't happen very often in such issues that people are ahead of the politicians," Gjellerup said, "because it's a little bit of an elitist question, you could say: minority rights." ${ }^{2}$ The opinion poll made it easier for some Social Democratic MPs, those who had been concerned about the attitudes in their home constituencies, to support the law. And by then the party leadership dealt firmly with dissenters. As the main party behind the proposal, it could not tolerate prominent members challenging the party line. In the end, some MPs were permitted to abstain from voting, but no one was allowed to vote against it. When asked, Gjellerup agreed that the resistance initially had come from older men in the party, but she did not think it was solely a question of age, and she had the impression that those with a specific professional background eventually would endorse the bill. The party's representatives in the Standing Committee for Social Affairs and in 
the Standing Law Committee were all for it. And she mentioned some older MPs from other parties who had voted in favour of it, like Ebba Strange from the Radical Left (RV) and Jens Peder Jensen, a gentleman in his sixties from the agrarian-liberal Left Party. Unlike most of his party fellows, Jensen supported the law, according to Gjellerup, purely on legalistic and humanitarian grounds.

In Norway, the elections of 1989 were a success for the Labour Party (Arbeiderpartiet). It did not, however, get a majority in Parliament, and a right-wing coalition Government was formed. But the opposition was strengthened, and an unprecedented number of members of the Labour Party's Youth League, AUF (Arbeidernes Ungdomsfylking), were elected to the Storting. There were many expectations that they would promote issues cherished by the AUF, one of them being gay and lesbian rights. The AUF group in Parliament decided that they would try to persuade the whole parliamentary group to present a bill on registered partnership modelled on the Danish one. They decided that Trond Jensrud would sign the bill, and then they would need a more experienced MP to support them. Grete Knudsen declared that she was willing to do that. With his twenty-one years, Jensrud (b. 1968) was the youngest person ever to have been elected to the Storting, but Grete Knudsen (b. I940) had been in Parliament since I98r. She had the reputation of being in the left wing of the party, and she had specialised in family politics. She seemed like the obvious choice for the younger Social Democrats when they wanted a more experienced ally. ${ }^{33}$

At the group meeting it became clear that Labour's parliamentary group would not support the bill, but Jensrud and Knudsen declared they would sign it anyway, as private MPs. Party leader Gro Harlem Brundtland said that she thought it unwise to go against the party line, but she did not try to stop them. When the next issue on the agenda was due, Knudsen stood up and hissed to Jensrud: "Trrrond! Come here! Let's go down and sign the bill! When we've signed it, these people can't blow it away!" Knudsen had a strong position in the party, and she didn't hesitate to confront the majority. According to Jensrud, they both got negative reactions from party members. For Jensrud it was especially unpleasant, given that everyone in Parliament was older and more experienced than he was. ${ }^{34}$

During the time the law proposal was being prepared, the situation changed and the Labour Party swung over to wholeheartedly supporting it. The chairman of $\mathrm{DNF}_{4}$ 8, Kjell Erik Øie, and his team of lobbyists had an important role to play in this, but there was also a shift in the overall political situation. "When the proposal came back we had formed a government, and Grete Berget, who was the Minister [for family matters], was in favour of the law," Jensrud explained. When it came time for the vote on the partnership law, another issue got mixed up with it. There was a proposal to protect certain waterways, which the AUF endorsed out of concern for the environment. But some people from 
the trade union movement, "power socialists" (kraftsosialister), as Jensrud called them, were against the protection of the waterways out of concern for local industry. On this issue, the party followed the trade union people and said no to water protection. The young socialists had to let go of the waterways, because if they had challenged the party line on this issue, the "power socialists" would have challenged them on the issue of registered partnership. It was a perfect situation for the group leaders, Jensrud said, because this way they could keep both groups disciplined. ${ }^{35}$ Since then, the shift of opinion within the Norwegian Labour Party has been swift and thorough, and the party leadership has had no problems relating to issues concerning gay and lesbian rights.

In Sweden the situation was different, and it was the grass roots movement that forced the leadership to adopt a more positive view on gay and lesbian rights. In an article from 1986, sex-reform activist Hans Nestius complained that the proposals put forth by the Homo Commission were not going to be prepared as a law proposal by the Government, since the Social Democratic Party's leadership was against it. The Minister of Social Affairs, Gertrud Sigurdsen, had addressed the International AIDS Conference in Stockholm and received an ovation when she announced that the Swedish Government would present a proposal to strengthen the rights of homosexuals. "Alas," Nestius wrote, "the applause came too early, because there will be no Government proposal in December ... Several ministers, led by Prime Minister Carlsson, questioned, among other things, one of the cornerstones of the proposal, namely that the new law on cohabitation for heterosexuals that recently was presented to the Riksdag should also include homosexual couples living together." ${ }^{36}$

There seems to have been some hesitation within the party, a fear of alienating parts of the core electorate if it began pushing too hard for such controversial issues. Whether or not the leadership was opposed or indifferent to gay rights issues, it did not push for them in the I980s. Two member's proposals concerning homosexuality were presented to the Social Democratic Party Congress in 1987, but neither was accepted..$^{37}$ The next Party Congress, in 1990, dealt slightly more favourably with the issue. The Stockholm Social Democratic Students' League suggested that the party should work for a law on registered partnership. The Party's Steering Committee recommended that the Congress wait for the result of the Partnership Commission, but during the debate several members disagreed with the Steering Committee. Anne-Sofie Hermansson from Göteborg said that the discussion was not always pleasant. "I'm tired of hearing comrades from our own ranks call these proposals 'faggot proposals," she said. As a compromise the Congress decided "that the proposal for legislation on registered partnership, which the Board of Health and Social Affairs recently presented, should be speedily handled by the Government and Parliament." ${ }^{8}$ 
Former Minister of the Work Market, Maj-Lis Lööw, who was a leading figure in the Social Democratic Women's League, and one of the architects of the radical family politics in the early I970s, had a key role, as chair of the Riksdag's Standing Law Committee, when the law was prepared in 199r. During the interview, she said that at the first meeting with the Social Democratic parliamentary group some members expressed reservations about the law. "As I remember, it was mostly women who supported the idea, and men who were reluctant - not all, but some." Even if the support was not unanimous, nobody said that they could not support the idea at all, so Löow and her allies in the Law Committee proceeded with their work. But the party leader, Ingvar Carlsson, told her that she had to make sure that the number of the majority for the law was not too small. It would not be wise, he said, to adopt such a controversial law with a majority of just one or two votes. Thus it was crucial to keep the Social Democratic group in Parliament together. At a late stage, there were some Social Democrats who declared that they could not vote for it, but if they had not declared their position earlier, they were not given any choice. According to Lööw, the party did not accept dissenting votes on this question, and they did not allow the reluctant to be absent. At the decisive vote on 7 June 1994, only ten out of 128 Social Democratic Members of Parliament were absent. Among them, however, were the party leader Ingvar Carlsson and the future party leader Göran Persson. ${ }^{39}$

The Finnish Social Democratic Party (Suomen Sosialidemokraattinen Puolue, SDP / Finlands Socialdemokratiska Parti) is perhaps more divided on this question than any other Scandinavian Social Democratic Party. In spite of the fact that Tarja Halonen had been chair of SETA and as a young MP had worked hard for gay and lesbian rights, the party itself did not place these issues high on its agenda. After she was elected President of the Republic in 2000, Halonen chose not to talk publicly on lesbian and gay issues, but the mere fact that she had once been chair of SETA and a gay rights advocate brought a lot of public attention to gay and lesbian rights and gave them a high degree of legitimacy in the eyes of the public. Gay activist Rainer Hiltunen summarized it thus: "Of course we would have wanted her to say more, but she had already said a lot to history." 40 As in all other parties, the Youth League and the women were more positive in regard to gay and lesbian rights, but in a large and hierarchical party like the Social Democrats they have seldom been successful in raising these issues. Tiina Kivinen, former chair of SETA and now head secretary of the Green Alliance's Parliament Group, commented on the split within the Social Democratic Party: "The divisions are not so much dependent on age or gender, as from where you come. There is a huge difference if you come from a city or the country, if you are from the north or south. Those are the main dividing lines." ${ }^{4}$

A problem for the Finnish Social Democratic Party, according to Hiltunen, was the importance of the trade unions within the workers' movement. "I think 
that in both the Social Democrats and in the Left Alliance it was the activists in the trade unions [who were against the partnership law], as, for instance, in the lumber industry trade union, a very masculine environment." Social Democratic Prime Minister Paavo Lipponen, in office 1995-2003, could not or would not prevent the National Coalition Party's Minister of Justice Kari Häkämies from blocking registered partnership for years. When Häkämies was replaced by Social Democrat Johannes Koskinen in 1999 the prospects for a law became brighter, but, according to Hiltunen, Koskinen was far from enthusiastic. "He was hesitant, he didn't give openly his support for registered partnership ... He forwarded the law and he voted yes." ${ }^{42}$ The rural-urban divide in Finland, and the big difference between attitudes to homosexuality in rural areas and in the cities, thus contributed to the enduring split within the Finnish Social Democratic Party.

\section{Agrarian and green parties: Toward acceptance}

In all Scandinavian countries, agrarian parties have played a significant role in the history of the welfare state. As a response to the economic crisis of the r93os, the Social Democratic parties and the Agrarian parties formed coalitions in all Scandinavian countries. These coalitions guaranteed the necessary political stability to carry out the welfare reforms that laid the foundations of the Scandinavian welfare states. 43

In Finland, Norway, and Sweden, the Agrarian parties were transformed in the I950s and I96os and changed their names to Centre parties in order to attract an urbanised electorate, but they retained strong ties to the agricultural sector. Ideologically, they harboured conservative convictions and Christian elements, but since the transition they have developed more liberal views. ${ }^{44}$

There are large differences between them, however. The Swedish Centre Party has abandoned its old cooperation with the Social Democrats and sought alliances with the political right. As a result, the polarisation of Swedish party politics has increased. This turn to the right has been accompanied by more "urban" views on marriage and sexuality, making it possible for openly gay Andreas Carlgren to pursue a career as the vice chair of his party. His presence at a high level in the Centre Party has probably facilitated the adoption of its present pro-gay politics. ${ }^{45}$ In Finland, however, the Centre Party is a strong conservative force and has proved to be the most stubborn opponent of the law on registered partnership when it was prepared. ${ }^{46}$ The Norwegian Centre Party (Senterpartiet) has made a move to the left. Traditionally, it has sought alliances with the political right, but since 2005 it forms a government with the Labour Party and the Socialist Left Party. It has gradually come to accept legal regulation of same-sex relationships, and when the joint marriage law was introduced, a minority within the Centre Party's group in the Storting supported the bill. ${ }^{47}$ 
The Danish Left Party is, despite its name, a liberal-conservative party that up until the r980s remained essentially agrarian. Except for a brief period at the end of the I970s, when it formed a government with the Social Democrats, it has always sought its coalition partners to the right. Its largely conservative stance may be explained by the fact that Danish agriculture is dominated by owners of medium-sized farms rather than smallholders. ${ }^{8}$ When the Radical Left Party split off in 1905, the Left lost its urban liberal electorate and became increasingly dependent on rural interests. Around the turn of the millennium, however, the Left Party became the largest party in Denmark and it promotes national-conservative values. Its attitude to gay and lesbian rights issues is coloured by its solidly liberal individualist convictions, and it generally supports bills that promote free choice for the individual. It is negative to the idea of gay marriage, but in 2009 six of its MPs made it possible to give adoption rights to same-sex couples by failing to vote the party line. ${ }^{49}$

Environmentalist or Green parties appeared in Finland and Sweden in the I980s and, in a sense, sapped the Centre parties of their more progressive forces. There was a moment in the I970s when the Centre parties harboured environmentalist interests that appealed to a generation critical of unlimited growth and a society structured around centralistic and hierarchical thinking, but these interests were in general taken over by the young Green parties..$^{50}$ In Sweden, it was the movement against nuclear power in connection with a referendum in I980 that formed the basis for the Environment Party's organisation. It attracted voters from all over the political spectrum, and for many years refused to place itself on the left-right scale in politics. Their stance on gay and lesbian rights has always been benevolent, and within the European Green movement it became a core element of their ideology. When the Riksdag voted in favour of a genderneutral marriage law in 2009, the Environment Party demanded a more radical solution: the abolition of marriage and its replacement with a civil registration act. From 2006 its influence in Swedish politics has grown considerably, since it is cooperating formally with the Social Democrats and the socialist Left Party (which dropped the word "Communist" from its name in 1990)..$^{5 \mathrm{~T}}$

Likewise, the Green Alliance (Vibreä liitto / Gröna förbundet) in Finland has consistently worked for gay and lesbian issues. It was established as a party in 1987, but already in 1983 the environmentalist network that preceded it managed to get two representatives into the Eduskunta via the Green lists they presented at the election. The head secretary for the Green Alliance's Parliament group, Tiina Kivinen, has worked hard within the party on gay and lesbian issues. She got the position as secretary for the Green Alliance in the Eduskunta in I99I, the same year she was elected chair of SETA. During her interview she remembered that some party members thought it was risky to give her the job as secretary. Perhaps the party would be accused of giving too high a priority to gay and lesbian issues. Since that time, however, she has never heard any such com- 
ments, and the Green Alliance is respected in Finnish politics as a party that has gay and lesbian issues high up on its agenda. It has an overall support of around 8 percent of the national votes, but is strongest in big cities. In Helsinki it received around 20 percent of the votes in the last elections, while in Lapland County in the north it got only 3 percent. ${ }^{22}$ The Green Alliance's Organisational Secretary and Member of Helsinki's Municipal Board, Hannele Lehtikuusi, was elected chair of SETA after Tiina Kivinen. Lehtikuusi was the one who consistently brought up adoption rights and the right of access to assisted fertilisation. A lesbian mother herself, she has contributed to the high visibility of lesbians and gay men with children in Finland. ${ }^{33}$

\section{Conservative parties: From opposition to acceptance}

The Scandinavian debate on registered partnership for same-sex couples can be seen as a process with many factors influencing decision-makers that slowly created a political landscape of acceptance. But alongside the slow building up of pro-partnership arguments, resistance to the law occurred and became increasingly ideological. Conservative resistance to gay and lesbian rights diminished over time, though it remained in religious groups within each party and in the growing Christian Democratic parties. In the I970s and I980s, the purely conservative argument against gay and lesbian rights was strong.

The Danish Conservative People's Party (Konservative Folkeparti) has been consistent in its resistance to extending gay and lesbian rights. As leaders of a minority Government, they were forced by a parliamentary majority to appoint a commission to investigate the living conditions for lesbian and gay citizens. Since they were against it, they did not lend any support to the commission's work. When the law on registered partnership was adopted, the Conservatives were unanimously against it. Though the party has since accepted the law, it has consistently opposed any additions to it. When MPs from its coalition partner the Left Party rebelled and voted in favour of adoption rights for registered partners in 2009, it provoked heavy criticism from the Conservative People's Party..$^{54}$

The Norwegian Right Party (Hoyre) had a brusque awakening in the fall of 1979, when their parliamentary representative from the Oslo Region and spokesperson on education, Wenche Lowzow, declared not only that she was a lesbian, but also that she was in a relationship with Kim Friele, the chair of the Norwegian national gay and lesbian organisation. In an interview in May the following year, Lowzow said she had not experienced any explicitly negative reactions within the party, but that she received considerably fewer invitations to speak to the party's district organisations. ${ }^{55}$ She was afraid there was a silent opposition to her presence, and in November she felt that her suspicions were confirmed when she was not renominated for her former position on the Oslo 
list. This provoked internal debate, and the national party secretary criticized the chair of the Oslo county organisation, which had failed to nominate Lowzow. According to the nomination committee, the reason was that Lowzow had become too narrowly focused on gay issues in Parliament, but the chair of the Oslo branch, Kirsten Lyche, spoke out more bluntly. She explained to the press that "out of consideration for the young generation it is wrong to normalise homosexuality. Think of all the parents who don't want their children to end up there. Lowzow should have told us about her orientation before we nominated her in the first place." ${ }_{56}^{6}$ Obviously, the public appearance of Wenche Lowzow in the Right Party forced the party members to consider and reconsider their opinions on homosexuality. In February I98I she was nominated again, but four years later the party leadership decided they did not want her as a candidate for Parliament..$^{57}$ In 1993, however, when the partnership law was discussed, the Right Party was split over the question. Its leaders were all against it, but some of their MPs voted in favour of the law. $5^{8}$ Around the turn of the century a number of prominent party members, among them the future Minister of Finance, came out to the press as gay. This resulted in some commentators calling it the Homo Party. ${ }^{59}$

In Sweden, when the law was voted on in I994, the Moderates (Moderaterna) were against it but they let their representatives vote according to their conscience. Only two of their younger MPs, Ulf Kristerson and Fredrik Reinfeldt, voted against the party line and supported the law. After a generational shift in the party, Reinfeldt is now its leader. ${ }^{60}$

In Finland, the conservative National Coalition Party was initially negative concerning gay rights and registered partnership, but the Secretary General of SETA, Rainer Hiltunen, was an active party member and exerted some influence within the National Coalition. When interviewed, Hiltunen insisted that there was no clear-cut left-right division in gay-rights issues in Finland. There were opponents and proponents of the law in every party, even if the support for the law "statistically" was more prominent in the political left. ${ }^{6 r}$

The only vote cast against the law on registered partnership in Iceland was from Árni Johnsen from the moderately conservative Independence Party, but his opposition to the law was the result of personal conviction rather than an expression of the party line. He was generally considered an eccentric and was not supported by his party. ${ }^{62}$

No Greenlandic party has expressly worked against gay and lesbian rights, but liberal-conservative Atassut politician Otto Steenholt voted against the Danish partnership law in 1989 when he represented Greenland in the Danish Folketing. When the proposal was brought up in the Greenlandic Inatsisartut in I994, he argued that it needed more discussion in Greenlandic society. In the end, however, he did not vote against it, but abstained from voting. ${ }^{63}$ 


\section{Christian Democrats and Radical Right: Bastions of resistance}

The Scandinavian Christian Democratic parties did not have any problems about their stand on the issue of registered partnership in the I99os. They were opposed to it and, in all the Scandinavian parliaments where they were represented, all their MPs voted against it. ${ }^{64}$ It is interesting to compare the fate of two leaders of the Christian Democratic Youth League, Anders Gassland in Norway and Erik Slottner in Sweden. In 1992, Anders Gåsland told the media that he was gay and that he supported the partnership law. This happened during the peak of the debate on registered partnership in Norway and was the least suitable moment for his mother party to deal with it. The Christian People's Party (Kristelig Folkeparti) lost momentum in its campaign against the law on registered partnership and, in the words of Kjell Erik Øie, campaign leader for registered partnership, "We then had the whole Christian block parked around that issue - they were just fighting over that." In effect, harsh reactions from some of the more conservative members of the Christian People's Party made people feel sympathy for Gåsland and move toward accepting the idea of registered partnership. Gåsland's friends in the Christian Democratic Youth League stood up for him and supported him, but the older and more conservative members did not. The party leader, Kjell Magne Bondevik, kept a low profile. According to Gåsland, the first thing Bondevik asked him was whether he had a boyfriend (which he did not). The question whether he was a practicing homosexual or lived in celibacy thus made a difference for the party leadership at this time. Shortly after the following year's elections, Gåsland left politics. ${ }^{65}$

In Sweden ten years later, an openly gay man was elected leader of the Swedish Christian Democratic Youth (Krist-Demokratisk Ungdom, KDU). Erik Slottner represented a liberal wing within the party, and his election was a victory for those who wanted to modernise the movement. Registered partnership was by now accepted by the Swedish Christian Democrats (Kristdemokraterna, $\mathrm{KD}$ ), and Slottner himself declared that he was opposed to adoption rights for homosexual couples. ${ }^{66} \mathrm{His}$ downfall was prompted by another issue. In 2005, a Pentecostalist minister, Åke Green, gave a sermon in which he branded homosexuality as a "cancer" and referred to Bible quotes condemning same-sex sexuality. His sermon was deliberately worded so that he could test the new law that prohibited hateful speech directed at a number of minority groups, among them homosexuals. ${ }^{67}$ In a TV studio, Slottner was pressed into saying that even preachers should not be allowed to propagate hate toward homosexuals. Shortly thereafter he was forced to resign as chair of Christian Democratic Youth. ${ }^{68}$

These two episodes illustrate how the Christian Democratic parties'stand on homosexuality had altered in ten years, or, rather, how the whole field of debate had changed. In 1992 the mere fact that Gåsland was homosexual was a problem, and it was an issue whether he lived as a celibate or not. In Sweden in 2005 the partnership law had been a reality for ten years, and an openly gay politician 
could make a career even within the Christian Democratic Party. But expression regarding these issues had been limited for Slottner and when he differed from the party line he was out. Ironically, the Christian Democratic parties in Norway and Sweden now have turned into the staunchest defenders of the partnership laws. In both countries their main argument against opening up marriage for same-sex couples was that the law on registered partnership was the best way to safeguard the legal interests of same-sex couples.

The new radical rightist parties in Scandinavia have evolved from anti-tax and anti-bureaucracy parties into being explicitly anti-immigrant and anti-gay. As so often, their histories differ in the various Scandinavian countries. In Finland, the Finnish Rural Party (Suomen Maaseudun Puolue) under Veikko Vennamo targeted the established politicians and urban interests and scored over ro percent in the 1970 elections. The Danish Progress Party under Mogens Glistrup relentlessly criticised high taxes. Glistrup claimed that tax evaders were to be hailed as freedom fighters, equally as heroic as the resisters under German occupation during World War Two. In the 1973 elections, the Progress Party became the second largest party in the Folketing with almost I6 percent of the vote. The Norwegian Progress Party was founded in 1977 and had its largest electoral success in the 2005 election with 22 percent of the vote, making it the second largest party in the Storting. In Sweden, the rather short-lived New Democracy held the balance of power in the Riksdag between I99I and I994. ${ }^{69}$

None of these parties initially had any fixed views on gay and lesbian rights, but they developed an explicitly negative attitude to these issues over time. The Danish People's Party, which is a direct successor of the Progress Party, but with a rather different programme, has said no whenever the left-leaning parties in the Folketing have attempted to extend the scope of the partnership law. However, they regard a liberal view on homosexuality as proof of traditional Danish tolerance, as opposed to the intolerance of "other cultures," and for a period they even tolerated an openly lesbian MP, Louise Frevert, to represent them. In an interview she emphasised that her party had no problems with lesbian and gay issues. The reason she was forced to leave the party was not because of her homosexuality, but because she went too far in spreading her aggressively anti-Muslim views. ${ }^{70}$ As opposed to the relative tolerance of the Danish People's Party, the Sweden Democrats, a party that had a considerable success in the 2006 elections and received 5.7 percent of the votes and 20 seats in Parliament in 2010 , is decidedly anti-gay. ${ }^{{ }^{\mathrm{I}}}$

\section{"A tribute to Kent": Shift of opinion in the nineties}

As mentioned earlier, only two Swedish Moderate MPs voted against the party line and supported the law on registered partnership when it was adopted in I994. One of them, Fredrik Reinfeldt, is now leader of the Moderates and 
Swedish Prime Minister. This is symptomatic of the rapid shift of opinion in the I990s. Politicians who supported gay rights in the I980s and early I990s were considered an embarrassment and many times were ousted from politics depending, of course, on which party they belonged to. As we have seen, Conservative MP Wenche Lowzow was not renominated after two terms, and she herself claimed that it was because she was openly lesbian..$^{72}$ Likewise, Trond Jensrud, the young Social Democrat who signed the first Norwegian bill on registered partnership, which went to Parliament in 1990, disappeared from politics, as did his colleague from the Progress Party, Jan Erik Fåne. ${ }^{73}$ However, their co-signer Kristin Halvorsen from the Socialist Left Party is now its leader and Norwegian Minister of Finance. Else-Merete Ross from the Danish Radical Left Party and Jörn Svensson from the Swedish Left Communist Party could both become and remain prominent MPs for their respective parties, even though they worked for gay and lesbian rights in the r97os. In Finland, one of those who worked early for gay and lesbian rights was Social Democratic MP Tarja Halonen. She is now President of the Finnish Republic. During the nineties it became more and more common that politicians supported gay and lesbian rights, or that they came out as lesbian or gay themselves.

The first Scandinavian MP to speak openly about her or his homosexuality after Wenche Lowzow was the young Swedish Social Democrat Kent Carlsson, who in 1991 came out to the media when two members of the right-wing populist New Democracy were expelled because of their homosexuality. In 1995 he was followed by Andreas Carlgren, a prominent name in the Swedish Centre Party. ${ }^{74}$ The first person to be elected to the Riksdag as an openly gay candidate was Tasso Stafilidis, who became an MP for the reformed socialist Left Party in 1998. He was also the founder of the Parliament's LGBT group (Riksdagens HBT-grupp), which has coordinated many LGBT-rights bills signed by MPs from different parties. ${ }^{75}$

In Norway, no other Member of Parliament came out after Lowzow until the beginning of the I990s. The first openly gay elected to the Storting was Labour Party's Anders Hornslien, who was elected as a deputy representative in 1993. In 1996 he became the first MP who registered partnership - and managed to get positive media attention in spite of the negative news about his part in a scandal concerning fraudulent membership lists of the Labour Party's Youth League. ${ }^{6}$ Since then, many Norwegian Members of Parliament have come out as lesbian or gay, among them, Per-Kristian Foss from the Right Party. He had been a Member of the Storting since 198I, came out to the media in 2000, and registered partnership and became Minister of Finance in 20or. For a long time, it had been an open secret that Foss and a handful of other prominent figures in the party were gay or bisexual, which may explain to some degree why the Norwegian Right Party was not more energetically against the partnership law. ${ }^{77}$ It was when the Right Party's Bent Høie and André Oktay Dahl also chose to 
come out publicly as gay in 200 I that their party was dubbed the Homo Party. ${ }^{78}$ There is a growing number of openly gay male MPs in all Scandinavian countries, but very few lesbians have come out. Siri Hall Arnøy, who was elected for the Socialist Left Party in 200I, is an exception. She was openly lesbian when she was elected, and her nomination was a result of her party's striving to become the most homo-oriented political party in Norway. ${ }^{79}$

In Denmark, the first MPs to come out were Yvonne Herløv Andersen from the Centre Democrats and Social Democrat Torben Lund, both in reality "outed" by the former head of the National Health Board, Palle Juul-Jensen, who had many conflicts with Lund concerning AIDS when Lund was Minister of Health. When Herløv Andersen succeeded Lund in 1994 the conflicts continued until Juul-Jensen was forced to resign from his post the following year. His revenge was to publish a memoir in 1996, in which he sharply criticised Herløv Andersen and Lund, and asked what his situation might have been "if the two latest Ministers of Health, not only politically but also personally, had had another relationship to the National Union for Gays and Lesbians." ${ }^{\circ \circ}$ Herløv Andersen and Lund were of course easy to identify, and shortly after the publication of Juul-Jensen's memoir, they both publicly acknowledged their homosexuality. Evidently their political careers did not suffer the least from the revelation. Even before coming out to the public, both Herløv Andersen and Lund were important influences within their respective parties.

Another important factor in facilitating the acceptance of the partnership laws by politicians was of course openly gay or lesbian friends and family of the decision-makers. In her interview, the leader of the Norwegian Socialist Left Party, Kristin Halvorsen, asked herself whether the gay and lesbian lobbyists knew that she had a gay brother: "Why on earth did they target me? Might there be someone who knew my brother?" In her autobiography, she admits that her brother was an important reason for her to work for gay and lesbian rights. ${ }^{81}$

Another example of the importance of lesbian or gay relatives occurred when one of the most prominent members of the Norwegian Centre Party, the Minister for Regional and Municipal Affairs, Magnhild Meltveit Kleppa, declared that she would support the proposed marriage law. To explain why she had changed her mind, she told the press that her gay son had been a good dialogue partner and had made her understand the hardships of lesbians and gays. "I think it is with me like it is with many others, that I previously haven't had this so close to me. That's the reason I have had a lack of knowledge, for instance, about the suffering that many young gay people still experience in this country, not least in the countryside, where it, in fact, affects the suicide statistics." She also said she hoped her voters in the rural region of Rogaland would understand her decision. With her background in the Inner Mission, it was doubtless a difficult decision to make. ${ }^{82}$ 
In Finland, Oras Tynkkynen from the Green Alliance became the first openly gay person in the Eduskunta when he was elected in 2004. Gay activist Jorma Hentilä was never a Member of Parliament, but as a party secretary for the People's Alliance he was a public figure in Finnish politics. His being gay was kept secret until the late i99os, however, another example of Finland's being a "late bloomer" in lesbian and gay politics.

Iceland and the Faroes represent special cases in the Nordic community. Iceland introduced the new legislation quickly, and even went one step ahead of the other countries in allowing joint custody of children. According to Lana Kolbrún Eddudóttir, it was the emotional impact of recognising lesbians and gays as members of society that was decisive for the Icelandic process. She succeeded Guðrún Gísladóttir as Samtökin's lesbian representative in the Homo Commission, and she worked hard, together with the other Samtökin representative, to convince the other members that lesbians and gays were ordinary people. This, she says, ultimately paved the way for a law that included children in the idea of a same-sex couple. "Icelanders are so used to extended families, and I think we made them understand that we, too, were part of the large Icelandic family. And that we had families of our own and that we were ordinary, friendly people." ${ }_{3}$

But if the "family effect" in Iceland prepared the ground for a rapid change of attitudes, it instead led to a painful exclusion from society in the Faroes. The influence of traditional religion, the small numbers of lesbians and gays who choose to remain in the islands, and the opposition to liberal ideas emanating from Denmark all contributed to the Faroes' status as the most homophobic society in the Nordic community. There is at present very little support for the lesbian and gay movement, and there are no openly lesbian or gay politicians who can lead the way toward acceptance. ${ }^{8_{4}}$

Kent Carlsson, the first Swedish MP to come out, did so in 1991 but died early, in I993. He did not live long enough to see the Swedish law on registered partnership, but he played no little part in influencing attitudes within his own party and in the Riksdag. Many persons have referred to him as preparing the way for the partnership law. During her interview, the former chair of the Riksdag's Standing Law Committee, Maj-Lis Lööw, remembered him in the political work for gay and lesbian rights:

I think Kent contributed a lot. He had a strong position, he was a colourful representative for the party, and everybody liked him. I think that in the end, and I think also at the Party Congresses, he had an important role. But then he died. In a way, the law became a tribute to Kent. ${ }^{85}$ 


\section{Conclusions}

When did Scandinavian mainstream politicians begin to listen to the demands of the gay and lesbian movement, and what made them listen? The processes that led to an almost complete acceptance of same-sex couples' right to marry and have children consist of an intricate interaction between legislative changes and shifting popular attitudes. On a higher analytical level, the new openness owes a lot to the end of the Cold War and the crisis of the welfare state. What U.S. philosopher Nancy Fraser called the politics of recognition became a much more prominent feature of world politics after 1989 . In the dichotomous world of the Cold War there was little room for demands from culturally or socially oppressed groups, and the inequalities due to age, disability, ethnicity, gender, race, or sexual orientation were either disregarded or made to fit into a teleological, class-based analysis. In contrast, the years immediately after the fall of the Berlin Wall and the collapse of the Soviet Union saw worldwide changes in the geo-political systems, and the fall of dictatorships in Africa, Asia, and Eastern Europe. This led to intensified work for human rights, which increasingly became defined in a broader fashion, now including rights for women, ethnic minorities, and people with disabilities, as well as for LGBT persons.

Since popular attitudes have become more accepting of homosexuality, it has also become a rewarding topic for politicians. It is easy to understand and explain, and it costs very little. Giving same-sex couples the right to marry entails limited costs for the state and gets high media attention, while dealing with pensions and health insurance is both complicated and costly. On 7 June 1994, the Swedish Riksdag voted on the law on registered partnership after years of heated debate, Government commissions, and lobbying work. The next day the pension system that had been in place since 1958 was abolished and a new system was adopted, without much public debate and with a minimum of news coverage. This way, symbolic questions like gay and lesbian rights can steal news attention from much more complicated questions that carry proportionally much greater consequences for more people. ${ }^{86}$

The opening up of marriage or marriage-like arrangements for same-sex couples of course has to do with the ongoing redefinition of marriage itself in Western society. Because of the changes in the legal and economic status of women in society, heterosexual marriage has been redefined during the last century, creating an institution in which the legal custody of the husband over his wife has been abolished, divorce facilitated, and taxation made separate. ${ }^{87}$ As Danish historian Karin Lützen put it in a 1998 article: "As a worn-out piece of folklore, marriage and perhaps even church weddings will be tossed at homosexuals." ${ }^{88}$ She has been proved right in her assumption that marriage and even church weddings have become possible for same-sex couples, but she underestimated the symbolic force of state recognition. 
The AIDS epidemic was important in influencing the views of politicians and people working in the health services, since they met a gay community in crisis and saw the needs of its members. All Scandinavian countries are so small that personal contacts and networks become very important for influencing public opinion. In most Scandinavian countries there were no serious conflicts between gay movements and the authorities, perhaps due to the reformist leadership of the gay movements as well as the understanding attitude from their governments. The AIDS argument, however, was only rarely used in any of the five Scandinavian countries. Instead, proponents of the law were concerned about fairness and equality, and the main effect of the AIDS epidemic was to direct media attention to the living conditions of gay men.

The first politicians who took up gay and lesbian issues were from the smaller ideological parties. From the beginning, demands for same-sex marriage arrangements came in a package of proposals that stemmed from a radical critique of the family, and the most important part of the package was the abolition of traditional marriage. These proposals were not successful, but they led to discussions on a high political level about alternative ways of looking at the family. The most interesting ideological change perhaps occurred when same-sexmarriage initiatives shifted from leftist demands for a redefinition of marriage, into classical liberal arguments of equality before the law. The latter approach does not question marriage as such, but pleads that its definition be widened to include same-sex couples. The bases of the two approaches are, in fact, diametrically opposed, but they can be combined for pragmatic politics and more limited demands.

Demands for gay marriage could not be allowed in the larger, class-based parties until a general change in public opinion had taken place. A generational shift in the political parties was crucial for this process. In all parties there were MPs who had a personal dislike of homosexuality and homosexuals. Also, many of them were afraid of negative reactions in their constituencies if they supported gay and lesbian issues. In the long run, however, these MPs either changed their minds or were marginalised as Youth and Women's Leagues in each party pressured for changed attitudes to homosexuality. When more and more politicians came out as lesbian or gay, first to their fellow party members and then to the media, the result was a change of climate which made lesbian and gay rights a part of mainstream politics. The generational shift eventually swayed the opinion within the conservative parties. There is a tradition of discreet homosexuality within the upper class, which sometimes could lead to understanding attitudes, as long as public scandal was avoided. This made it easier to accept pro-gay legislation for some members of the older generation in the conservative parties. The younger generation, with its stronger emphasis on neo-liberal values, embraced pro-gay legislation more whole-heartedly, seeing in liberated sexuality a precondition for the freedom of the individual. Finally, the lobby- 
ing efforts by the Scandinavian gay and lesbian movements in the r 980 and the I990s were crucial for influencing the attitudes of mainstream politicians. In Norway, the activists of the national gay and lesbian movements were lauded afterwards by politicians from different parties, who described the activists as well read and efficient.

In the end, even the Christian Democratic parties were influenced by the general change in opinions during these years. They had been consistently opposed to a law on registered partnership, but when the debate turned toward granting marriage to same-sex couples they claimed that the partnership law was a good law for homosexuals. In the debate, they had been accused of betraying the Christian core values of love and compassion. They had replied by stressing family values, but their anti-gay stance received diminishing support from Scandinavian society.

The most important factor, however, was the specific structure of the Scandinavian welfare states, which made them such a fertile ground for lesbian and gay law reform. A long tradition of consensus made a polarised debate less likely, and in fact led to the shaming of the most outspoken opponents of gay and lesbian rights. A strong emphasis on fairness and equality contributed to the success of the arguments based on these values and was crucial in getting support from the large Social Democratic parties. Stable political institutions guaranteed that the issue stayed alive through many shifts of government, and well-established, trade-union-like lesbian and gay movements kept the channels open to elected representatives. The limited size of the Scandinavian countries led to an overall acceptance of the new laws and created a positive atmosphere around gay and lesbian members of society, an effect most clearly visible in Iceland, where the whole country very quickly became supportive of gay and lesbian life and culture. Finally, armies of loyal civil servants guaranteed the swift implementation of the new laws. The next chapter will deal specifically with the obstacles that were there before the new institution of registered partnership found its place in society. 


\section{Chapter Four: Implementation}

The fear of negative consequences of the registered partnership law was not exactly widespread in Scandinavia, but it could be dramatically formulated. When the Danish partnership law became effective on I October 1989, five men and one woman voiced their concern in a letter to the editor of a local newspaper:

October Ist - a fatal day - a death sentence! We Danes and not least we Christians have signed our own death warrant! ... So far out in the mud have we come, we Danes, that other countries must regard us as the country most polluted by sin in the world!

This argument cannot be regarded as representative of many Danes, but it expressed the feelings of some of those of a Christian conviction who opposed the law. Denmark would be punished by God and disregarded by other nations. As far as it is humanly possible to ascertain, this has not happened, but the law in Denmark - and in the other Nordic countries - nevertheless has had effects, not only on the lives of the gay and lesbian couples who used it to regulate their relationships but also on society as a whole. Here we will examine the immediate aftermath of the laws in the various regions of Scandinavia, the struggles to obstruct their implementation, and the initiatives to widen their scope. We will discuss the effects of the partnership laws on society as a whole and will trace the development from state recognition of the childless same-sex couple to that of the procreative rainbow family.

\section{Smooth implementation in Denmark}

When the law was first adopted in Denmark, it was supported by more than half of the population, but as the quote above indicates, there were those who feared that it would harm Denmark as a nation, and that it was a violation of the Christian values that Danish society was built on. Immediately after the bill had been voted on by the Danish Parliament, the small Christian People's Party (Kristeligt Folkeparti) demanded a referendum. However, they were far from having the necessary sixty signatures in Parliament which would force the Government to order it. Only their own four members and a handful of members from the right-wing populist Progress Party signed their petition. The Conserv- 
atives and the right-of-centre liberal Left Party (Venstre), which also opposed the law, considered a referendum to be the wrong way to handle the situation. According to political commentators at the time, the most probable cause for their refusal to sign the petition was the support for the law expressed in the opinion polls. ${ }^{2}$

There were also direct obstructions on the local level. The Danish press reported in January I990 that the Conservative Mayor of Vallensbæk municipality, Poul Hansen, refused to register partnerships. The LBL protested, but in a letter to the gay and lesbian organisation, Social Democratic MP Pia Gjellerup downplayed the importance of the Mayor's demonstration: "There is no faltering in the support for the law - not in the Folketing either (except for the Christian Democrats of course). A law is a law and it must be upheld in all places. Poul Hansen is a little bit the laughing matter in this, but so he is in various contexts."

The law had consequences on many levels, and the gay and lesbian movement was active in some instances in influencing its implementation. In December I990, the LBL noted that Statistics Denmark still listed people living in a registered partnership as unmarried. The reason the statisticians gave for this in their monthly publication was that they regarded marriage as "a unit with a reproductive quality," and that the calculation of fertility quotients depended on an internationally comparable definition of marriage. In a letter to Statistics Denmark, LBL's chair Else Slange then asked whether all married women who had passed the age of fertility should also be regarded as unmarried. She suggested that Statistics Denmark separate the categories to enable international comparison, and she complained that the current practice would render registered partners invisible in statistics. ${ }^{4}$ In a letter to LBL in January 1992, Statistics Denmark announced that they were in the process of changing the presentation of data on marital status, and in March 1993 they informed LBL about their new way of presenting it. From I January 1992, Statistics Denmark added three new marital statuses to the four traditional "unmarried," "married," "divorced," and "widow/er," namely: "registered partner," "dissolved registered partnership," and "longest living registered partner." Because of the striving to preserve the category of married people intact, the three new categories were created with only a small number of individuals in each. From that day, there were separate columns also for registered partners, divorced partners, and widowed partners, a practice which would be followed by the statistical bureaus in the other Nordic countries. Even if they were of little consequence for Danish citizens in general, the establishment of the new categories shows how the institution of registered partnership caused family as a statistical unit to be redefined. ${ }^{5}$

Heads of Section Henning Christiansen and Anna Qvist both worked at Statistics Denmark when the new law forced them to create new categories. Henning Christiansen said in an interview in 2008, that it was the low num- 
bers of the registered partnerships that made them hesitate: "All the tables concerning marital status had to be expanded from four, I think, to seven columns, and in those days data bases weren't as easy to handle as they are today, so we thought that it was too much work connected with something that concerned so few." His colleague Anna Qvist remembers that she felt insecure because she did not have any precedent. "We were in the dark. It was something completely new. Should we consider them as married couples or ... In the beginning we classified them as unmarried. They didn't like that." ${ }^{6}$

An issue that took some time to settle was the question of widowers' pensions. The Danish pension system is based on a flat-rate state pension that does not guarantee the level of income, and it is therefore supplemented with a system of pension insurances administered by trade unions and private companies. In 1990, there were $3 \mathrm{I}$ branch-based pension funds - like the Pension Fund for Danish Lawyers and Economists (JØP) and the Danish Pension Fund for Engineers (DIP) - and I2I corporate-based pension funds. 7 The law regulating the pension funds overruled the Partnership Law, because the Partnership Law explicitly stated that "Regulations in Danish law which contain special rules about one of the persons in a marriage who is specified by sex will not be used for the registered partnership." ${ }^{8}$ Most pension funds quickly changed their statutes in order to grant pensions to the surviving partner in registered partnerships that had been dissolved by death, but during the first phase of the transition, some individuals were victims of slow decisions. One such case was the "Leif case" from 1990 , when a person did not receive a pension because his partner died in May and the pension fund changed its statutes in July. One of Denmark's largest employers, the Danish East Asiatic Company (Østasiatisk Kompagni, ØK), was also slow to adapt to the new situation. ${ }^{9}$ But it was the Danish Engineers' Pension Fund, DIP, that became branded as discriminatory when it failed to change its statutes on two occasions. It was not explicitly stated, but in view of the ongoing AIDS epidemic, the reluctance to include a group with higher mortality than average could have been dictated by economic considerations. ${ }^{\text {IO }}$

Because of the urgent situation for many gay men whose partners were dying of AIDS, the LBL then wrote a letter to the Standing Law Committee (Retsudvalget) of the Folketing and suggested law changes to correct the situation. They pointed out that around fifty partnerships per month were registered in Denmark. The couples lacked the possibility of adopting one another's children, LBL wrote, but that was a legal situation that the Folketing had intended. As opposed to this, the discrimination against same-sex couples by the large pension funds was not intended and could easily be ended by legislation. ${ }^{\mathrm{II}}$ There was no revision of the law that would force pension funds to include gay and lesbian widows in their systems, and no MP presented any such proposal, but it seems that all private pension funds soon adjusted their statutes to do so. 
Another area that was affected was the various reductions heterosexual couples were offered on public transport, in hotels, and the like. There was nothing in the new law that could force public transport companies or hotels to give the same reductions to registered same-sex couples as to heterosexual ones, but the law served as a powerful signal to society. Several Danish companies declared within months from the law's implementation that they would extend the benefits granted to heterosexual couples to same-sex couples. The airline company SAS and the Danish State Railways were among the first to make such announcements. Since SAS is a joint Scandinavian company, this had effects also in Norway and Sweden..$^{\mathrm{I}}$

Part of the history of the implementation of the partnership law is the wave of benevolence toward gay people that swept over Denmark. There were negative reactions, to be sure, but, on the whole, it seems that more and more Danes took pride in displaying tolerant attitudes toward lesbians and gays. When Pia Gjellerup was asked why she thought Denmark, and no other country, was first in the world to adopt such a law, she hesitated and then explained:

It confirmed a conviction among Danes that we can be decent people ... You know, we love the story that the Jews were saved in Denmark ... It's the good story. All nations have their good stories. And this is the one that will be told when we want to say that this was the good story from the end of the twentieth century. That's good. That way, small countries have a chance to make great things happen. ${ }^{{ }_{13}}$

\section{Religious resistance in Norway}

In Norway, the introduction of the law met with a more articulate resistance, and it was mainly from Christian circles and in rural areas that there were negative reactions. ${ }^{14}$ When the partnership law was already adopted by the Storting, but before it became effective, an MP from the Christian People's Party proposed that marriage registrars (sorenskrivere) should have the possibility of refusing to perform partnership ceremonies if it was against their personal belief. The proposal was rejected by the Storting majority without debate. ${ }^{15}$ The following year, the leader of the Christian People's Party, Kjell Magne Bondevik, moved that the law should be revoked, but his proposal was rejected after a short debate in the Storting. ${ }^{16}$ These two attempts to obstruct or abolish the new law received little support in the Parliament, and it was in other areas that the struggle over the implementation of the new law was to be waged.

The post-law debate in Norway was focused on the Church and whether it could condone homosexual practice. Already in 1977 the Norwegian Church Meeting, the highest decision-making body of the Church of Norway, had decided that it could accept homosexual orientation but not homosexual practice, and that decision was to be the guiding principle for a majority of the Church 
for a long time. The Church Meeting of 1995 decided after lengthy discussions to uphold the principle laid down in the 1977 declaration, that it accepted homosexuals but not their sexual practice, which meant that the Church could not have practicing homosexuals as priests, deacons, or catechists, i.e. any office that involved religious consecration. Among those who voted against the 1995 decision were three of Norway's eleven bishops, a foretaste of the deep tensions that were to threaten the unity of the Norwegian Church in the years to come.77

\section{Local politics in Sweden}

As in Denmark and Norway, there was widespread celebration in Sweden when the law became effective. National and local media ran big feature articles showing happy couples preparing for their registration, or encountering cheering crowds outside the courthouse. In the midst of this celebratory mood there was also some disappointment that there were only a limited number of same-sex couples who showed up. One local newspaper published an ad looking for lesbian or gay couples who were prepared to register and would consent to be interviewed. That way, the new law even created a demand for homosexuals where previously there had been none. ${ }^{18}$

However, obstructions to the law were more widespread in Sweden than in Denmark and Norway, the most serious being the refusal by some municipalities to appoint partnership registrars. The formalities around a partnership registration differed slightly within Scandinavia, depending on how civil marriage ceremonies were organised. In Sweden, all judges employed by a District Court were obliged to perform both marriage ceremonies and partnership registrations. In addition, each local municipality had to nominate one or more civil marriage registrars who were to be officially appointed by the local state representatives in the County Administrative Board (länsstyrelsen). Already in December 1994, before the law was effective, both civil marriage registrars in Örkelljunga municipality, in southern Sweden, declared that they would refuse to perform the corresponding ceremony for same-sex couples. "Don't forget that matrimony is a holy act, even when it is a civil ceremony," one of them declared in the local newspaper. ${ }^{19}$

One month after the law became effective, 93 out of Sweden's 288 local districts had failed to nominate a partnership registrar. ${ }^{20}$ This delay in the implementation of the new law was generally interpreted as an unwillingness to accept its consequences. Many letters to the editor in local newspapers gave support to or condemned those who delayed the process, and several of the marriage registrars had to defend their position publicly. ${ }^{21}$ The fact that many of the marriage registrars were politically active, and in effect nominated by local party organisations, created tensions within the political parties. Vice Prime Minister Mona Sahlin wrote a sharp letter to the Social Democrats' district organisations 
in which she demanded that Social Democratic marriage registrars who refused to perform partnership registrations should reconsider. ${ }^{22}$ At the same time, the Youth League of the Centre Party demanded the same thing from the marriage registrars of their party. ${ }^{23}$ In 1997 the Moderate MP Fredrik Reinfeldt was nominated as marriage registrar by his party. He then declared that he also wanted to register partnerships. On this occasion, he told the reporter that he had encountered many negative reactions from within the party for his support of gay and lesbian rights. "It was tough then, tough internal negotiations. Some, especially among the older members, were rather unreasonable with me." ${ }_{24}$

The discussion about the communal partnership registrars continued for several years and each time stirred debate in the local media. In May I999, one of the first actions of the recently created Ombudsman against Discrimination on Grounds of Sexual Orientation was to reprimand three municipalities that had been reported by RFSL for not having any partnership registrars. The local councils of Timrå and Mariestad quickly chose to nominate registrars. Örkelljunga was recalcitrant, and the tone of the debate got heated, but the Ombudsman could count on the support of the new Social Democratic Government. In May 2000 the law was changed so that the two offices were combined. After that, anyone who applied for the position of registrar of civil marriages would also have to be prepared to perform partnership registrations. However, those already commissioned were exempt from having to perform the double duties. Those who were commissioned by a religious congregation also were not under any obligation to marry couples they did not consider fit for marriage - whether they were divorced or because they belonged to the same sex. After the turn of the millennium, the discussion about registered partnerships and the Church took a somewhat unexpected turn in Sweden. In 2000, a lesbian couple had a ceremony in a church in Gothenburg, where they were registered by a registrar and blessed by a priest. This provoked a complaint, and the following year the Bishops' Meeting officially banned registration ceremonies inside the Church. The gay priest and activist who had officiated, Lars Gårdfeldt, then quickly invented the "Church Stair Wedding" (kyrktrappsbröllop), a new word which soon entered the Swedish vocabulary. In these ceremonies, the partnership was registered on the Church Stairs and then the couple proceeded into the Church to be blessed by the priest. The Bishops' ban on partnership registrations in Church lasted until November 2009, when the Church of Sweden decided to perform legally binding Church weddings. ${ }^{25}$

\section{Religious debate in Iceland}

In Iceland, as in Norway, the debate about the new law mainly concerned the attitudes of the Church. But unlike in Norway, the Icelandic State Church did not have much influence in politics. There has never been any Christian Dem- 
ocratic party of significance in Iceland, and Icelanders are not known to be a particularly religious people. Iceland was also the country in Scandinavia where the law on registered partnership was most warmly received by the state. Only one member of the Alpingi voted against the new law, and the President of the Republic honoured the first registered partners with her presence at their reception. There seems to have been very little resistance on the local level, and press commentaries were generally favourable. Joint child custody was accepted to a limited extent when the law was first adopted. In 1997 there was a proposal to allow for stepchild adoption, which became a reality in 2000 when the partnership law was revised. ${ }^{26}$

One bone of contention, though, was whether the Icelandic People's Church should create a blessing of same-sex couples. The Church was deeply divided over the issue, and it was this question that would provoke the most heated debate about the legitimacy of same-sex couples in Iceland. In September 1999, Ólafur Stephensen wrote a letter to the editor of Iceland's largest newspaper criticising the State Church for not recognising same-sex couples and for choosing to interpret the Bible in an intolerant way. Stephensen argued that homosexuality "is part of the Creation, and consequently the will of God," and he claimed that the Bible is full of inconsistencies and that it should be used to find strength and faith, not to condemn other people's lives. ${ }^{27}$ Ten days later, the priest Ragnar Fjalar Lárusson answered him, saying that he found himself forced to counter such distortions of the Faith: "Most priests in this country, as well as the leaders of the Church, let such criticism blow past their ears without responding to it. They are completely silent, so that they won't offend anyone!" Lárusson did not want to characterise homosexuality as a sin, however. Homosexuals cannot help the way they are, and "the Church of Christ may never condemn anyone for the sickness he carries. ${ }^{28}$ His article provoked the intellectual establishment, and in the ensuing debate the majority of those involved condemned his views. In a society built on consensus, it was almost as if the public had been waiting for this opportunity. ${ }^{29}$

\section{Silence in Greenland}

The most striking feature of the implementation of the law in Greenland was that nobody noticed that it was there. After the initial debate in the Greenlandic press in 1994 when the Greenlandic Parliament, the Inatsisartut (or Landsting), had decided to introduce the law on registered partnership, there was a complete silence. When the law was finally effective, two years after the political decision, there was not a word about it in the newspapers. There was no gay and lesbian movement yet, and nobody in the cultural and political establishment brought the law up for discussion. Statistics Greenland has never considered making registered partnerships visible in their reports or on their home page, 
and lesbians and gays remained relatively invisible in Greenlandic society. The Mayor of Nuuk, Agnethe Davidsen, who reportedly has performed two of the registrations in Greenland, has so far refused to deliver the dates of the registrations or confirm their number..$^{3^{\circ}}$ In such a small society as Greenland, though, with only 56,000 inhabitants, people are bound to know a lot about each other, and the first lesbian couple who registered was already known in Nuuk, where they lived, and in their respective hometowns of Ilulissat and Qeqertarsuaq.

Estrella Mølgaard and Regine Jørgensen met in a boarding school in Denmark in 1983 . They became lovers, and when they moved back to Greenland they decided to be open about their relationship. The first years were hard, they told me, but gradually their families and friends accepted their relationship. In 2002 they decided to register their partnership. Since the introduction of the law in Greenland had been surrounded by total silence, Mølgaard and Jørgensen did not know when the law on registered partnership had become effective. They just assumed that the Danish law from 1989 was also valid in Greenland. When they decided to register, they had already been together for nineteen years. When they told their families that they were going to register their partnership, some relatives reacted negatively. To publicly announce their relationship by the act of registration obviously was a very serious indiscretion. In 2004, when they appeared in an interview in Greenland's largest newspaper, they met with more negative reactions from some family members. ${ }^{35}$

The visibility of lesbians and gay men in Greenland was not brought about by legislation, but by the emergence of a gay and lesbian lobby group. In 2002, gay radio journalist Erik Olsen decided to start an organisation. He let himself be interviewed anonymously in Greenland's largest newspaper, but he made sure that the journalist published his e-mail address. He got more response than he had dared hope for, and in a very short time he had assembled a gay and lesbian rights group in Nuuk, Qaamaneq (The Light). ${ }^{32}$ With the emergence of a gay group, and of a handful of lesbians and gay men who appeared openly in the media, there was suddenly a focus for discussion about gay and lesbian rights in Greenland. It was thus not the partnership law as such that increased openness in Greenland, but the initiative of organised lesbians and gay men.

\section{Ambivalent politics in Finland}

In Finland, the law on registered partnership became effective on I March 2002, eight years after the first initiative had been rejected by Parliament. The Finnish debate on gay and lesbian rights had been intense even before the law, and when the new law was introduced, old and new demands were mixed. Already at the beginning of May 2002, the Government appointed a commission within the Ministry for Social Affairs to investigate the legal rights of registered couples, including the possibility of adoption rights and assisted fertilisation. ${ }^{33} \mathrm{At}$ 
the same time, the Finnish Evangelical Church gathered for its annual meeting and had to deal with two diametrically opposed proposals: one, that the Church should create a ceremony for blessing same-sex couples, and the other, that the Church should ban gays and lesbians from working within the Church. ${ }^{34}$ An opinion poll showed that only 30 percent of the Finnish population were in favour of a ceremony for the blessing of same-sex couples, and when Bishop Wille Riekkinen in Kuopio declared that he was ready to perform such a ceremony, he was immediately reported to the Church for compromising the evangelical foundations of his office. ${ }^{35}$ Minister of Justice Johannes Koskinen from the Social Democratic Party sharply criticised the Church for even discussing a ban on registered partners working for it, calling it anti-constitutional, but after a while he admitted that the Church had the right to demand that persons in "spiritual" positions follow its teachings. ${ }^{66}$ The debate within the Finnish Evangelical Church went on for a long time, and still goes on, but the Finnish Orthodox Church to date has no regulations concerning homosexual employees. ${ }^{37}$

These questions, however, were largely internal matters for the two State Churches in Finland and, as opposed to Norway in the I99os, they did not spill over into the general debate. Outside the realm of religion, public discussion focused on the rights to adoption and assisted fertilisation. Opinion polls showed - again - that Finland's rural and urban populations were divided and that support for gay and lesbian parental rights was stronger in the cities. The polls also showed that women were more supportive than men in these matters. ${ }^{8}$ It was also a generational question, and younger politicians from several parties expressed their support for the idea that same-sex couples should be able to adopt children..$^{39}$ An issue that became especially controversial in Finland was the question of assisted fertilisation. The Finnish gay and lesbian movements had been adamant in their demands for parental rights, and the gay and lesbian campaign for registered partnership in Finland focused more on parenthood than in any other Scandinavian country. The lobbying for registered partnership in Scandinavia in the I980s and early I99os consciously avoided the mention of, or explicitly excluded, children from the discussion, but in the late rg9os and early twenty-first century, the children of gay and lesbian parents entered the discourse. By initially focusing on existing children with lesbian or gay parents and pointing out their need for legal security, the gay and lesbian movement also paved the way for positive decisions on assisted fertilisation. Moreover, since there was no law at all regulating assisted fertilisation in Finland, a practice developed after the mid-rg9os of private fertility clinics accepting both single women and lesbian couples. This was unacceptable to many conservative Finnish politicians, who strove for a strict regulation of assisted fertilisation. ${ }^{40}$ But just as the law of registered partnership had been delayed because progressive and conservative forces blocked each other, the law on assisted fertilisation 
also took time to get passed. The new law, allowing access to reproductive technologies for lesbian couples and single women, was not enacted until $2007 .^{4 \mathrm{I}}$

\section{Conclusions}

What, then, were the effects of the initial partnership laws? Contested from left and right, for threatening family values or selling out to them too easily, they were a compromise from the beginning, excluding church marriages and children, but setting up extra strict requirements for citizenship. Scorned by some as a second-rate marriage, and detested by others as the end of civilisation, they did indeed have far-reaching effects in Scandinavian society.

As I have shown, the mere existence of the laws created a demand for the recognition of homosexuality in local communities. At the same time, however, state recognition placed claims on same-sex couples as well as on their environment. What can be more disciplining than the act of pronouncing a couple man and wife, thus anchoring them in the social fabric with vows of fidelity and expectations of providing offspring to their kin, society, and nation? Urbanised modern society has relaxed some of the expectations and granted more freedom to individuals, but the symbols and discursive framework around marriage remain. What same-sex couples achieved in 1989 in Denmark, and between 1993 and 2002 in the rest of Scandinavia, was a special legal arrangement in which the demands of fidelity were implicitly present, but procreation and child-rearing had been removed. Sprung from urbanised modern society, the gay and lesbian subculture reserved its right to interpret marriage in various, individualised ways, but the main reason for the rapid acceptance of the new laws was that the majority culture could mirror itself in them.

On the other hand, the regulation of same-sex bonding also destabilised traditional concepts of marriage. The institutionalisation of gay and lesbian couples increased visibility for all non-heterosexual people in Scandinavia, as the implementation of the partnership laws coincided with the introduction and proliferation of queer theory.42 There was a lot of interest in queer theory in the national news media, which led to further diversification of the image of nonheterosexuality. The laws on registered partnership were only part of that image.

However, the most important effect was the spread of gay and lesbian presence from the centre to the periphery in each country, as well as from the centrally placed countries in Scandinavia to those in the periphery - most notably Finland in the East and Greenland, Iceland, and the Faroes in the West. All over Scandinavia, the debate about the laws helped spread the idea of homosexuality over the whole territory. Before, it was generally thought of as an urban phenomenon, concerning only a small segment of the population, but that was to change. ${ }^{43}$ In every single municipality decisions had to be made as to who should deal with the potential partnership registrations. Local newspapers had 
to decide whether to publish paid partnership announcements, and, if so, under what heading. In the local press, as well as in the national media, politicians who obstructed the laws were branded as backward and intolerant, and a growing number of articles featured happy same-sex couples, with or without children. All of this influenced public opinion. Moreover, what emerged in the columns of the Scandinavian press during the I99os was a clear-cut generational divide. The younger politicians seemed to embrace the ideas of partnership and equal rights for homosexuals, whereas the older generation was more reluctant. The remaining battleground was - and is - within the national churches. Because of a Scandinavian history of state churches that administered civic registration and marriage ceremonies, it was very important what they thought of homosexuality and gay marriage. Increasingly, however, the question of religious recognition has been handed over to the churches themselves to deal with, and public discussions increasingly have focused on the question of parenthood.

As we have seen, the gradual fertilisation of the once childless gay and lesbian couple came about as a logical consequence of the laws on registered partnership. Stripped of children and religious ceremonies, the first registered couples nevertheless carried the potential for both. They were presented in the press either as young and starry-eyed with a bright future ahead of them, or as mature couples who were granted their official status as a reward for their long and faithful relationship. And as I have pointed out, the laws on registered partnership created their own demand. Two Swedish gay men, interviewed in 1997, claimed that it was their heterosexual neighbours who had persuaded them to register their relationship after having been together for forty-eight years. They had become close to the young family next door over the years and had acted as gay "grandfathers" for the family's children. When the law on registered partnership became effective, it was mainly the children who insisted, and the gay men agreed to register their partnership, even though they thought it was unnecessary after so many years. As a celebration, the neighbour family improvised an altar in their living room, and the sixteen-year-old son learned to play Mendelssohn's wedding march on the guitar. It was a beautiful ceremony and the two men were profoundly moved. Not even the discovery that their pensions were reduced, since they were no longer registered as unmarried, made them regret it. ${ }^{44}$

At this time, the national media presented older, childless gay and lesbian couples alongside young, potentially parenting couples. Sometimes, though not always, the young couples would tell reporters that they thought of having children in the future. But same-sex couples with children were not featured in the press. Only toward the end of the I99os did they begin to appear regularly, in connection with the increasingly intense debate about the rights of children with lesbian or gay parents. Before that, media had not shown much interest in the matter, and gay and lesbian parents had good reason to stay out of it, because 
of the negative attitudes toward their families. When Denmark introduced the ban on insemination for lesbians and single women in 1997 , followed by a law on stepchild adoption in 1999, the issue was brought to public attention, and from around then gay and lesbian couples have been more readily connected with child rearing in the public mind.

The next chapter will demonstrate the gendered character of the partnership laws and discuss how the lesbian baby-boom in the rg9os coincided with a more pronounced lesbian interest in the registered partnership laws. 


\section{Chapter Five: \\ Gender and marriage statistics}

When the law on registered partnership was first introduced in Denmark in 1989, international press coverage was extensive, and the pictures of the aging gay couple Axel and Eigil Axgil went all over the world. Axel Axgil was the founder of The Society of 1948 and he and his partner had worked for many decades for lesbian and gay rights in Denmark, so it seemed natural that they would be given the honour to be first. They had waited long, but now they were the first registered gay couple in the world and were celebrated by a huge crowd in Copenhagen's City Hall Square. The tone in the press was generally happy and generous, and many newspapers took the opportunity of congratulating all homosexuals for their victory. ${ }^{\mathrm{I}}$ Some of the reports, however, showed some disappointment. After so much debate and confrontation, it turned out that relatively few persons took advantage of the new law. Moreover, very few women had their partnership registered. When the law became effective on I October 1989, eleven male couples registered in Copenhagen's City Hall, but there were no lesbian couples. According to the morning paper B.T., the Danish Gay and Lesbian Association LBL explained the absence of women by saying that they were "afraid of publicity" and were waiting till another day when there weren't so many journalists around. But the newspaper noted that lesbian interest in the law still seemed low after nearly two weeks. ${ }^{2}$ Here the journalist hit a sore spot within the Danish gay and lesbian movement. As we have seen in previous chapters, the law was a project mainly fought for by gay men, while there was strong resistance among lesbian feminists against a law that emulated heterosexual marriage. As has already been pointed out, this must be placed in the context of second-wave feminism in the I97os, which saw the heterosexual nuclear family and marriage as the cornerstones of patriarchy. The dominating feminist discourse in the I970s was built on various theories of patriarchy, and for most feminists gay marriage was an oxymoron. That was one of the reasons the chair of LBL, Else Slange, refused, when she was asked, to recruit lesbian couples for the first registration ceremony. Like many other lesbian feminists in the gay and lesbian movement, she did not believe in the idea of gay marriage or registered partnership, and she did not want to work for it. But on the other hand, she chose not to lobby against it, and the issue was not important enough for her to cause a split in the movement. ${ }^{3}$ 
Statistical evidence indicates that women chose not to take advantage of the law in the beginning of its existence but that they later became more interested in registering their partnerships. Here we will look closer at some statistics concerning the changing patterns of registering. We will also compare Scandinavian figures with corresponding statistics in the Netherlands, which show significant differences and similarities.

All in all, there are four characteristics that national statistics on partnership registrations display in all the four Scandinavian countries that have large enough populations to provide significant figures. First, the built-up demand for the reform resulted in an initial number of registrations that were three or four times as high as the following years. ${ }^{4}$ Second, the number of partnership registrations compared to the number of marriages was much lower than could be expected if homosexuals were ro percent of the population, as has often been claimed. Third, the male and female partnership registrations show that the propensity to register was much lower among lesbians than among gay men in the r99os, but that this tendency was reversed during the first years of the new century. Fourth, there has been an increasing tendency, on the whole, to register partnerships in all Nordic countries since the turn of the century. All of these characteristics will be discussed below.

\section{Initial marriage boom}

The high numbers of partnership registrations during the first year the laws were in force are perhaps the least surprising fact of the partnership statistics (see $\mathrm{Ta}$ ble I). Men and women of all ages who lived in steady relationships with partners of their own sex were waiting for the reform, and as soon as the laws went into effect many of those who had long wished to marry hastened to register their partnership. That way, a built-up demand led to high numbers during the first years, an increase of registered partnerships that soon levelled off. One result of the initial "marriage boom" was that the world had never before witnessed so many elderly brides and bridegrooms. Data from a Norwegian-Swedish survey from 2006, led by Swedish demographer Gunnar Andersson, suggest that the average age of couples registering partnership was considerably higher than that of heterosexual couples who marry. ${ }^{5}$ There are reasons to believe that samesex couples generally would wait longer to get married, since the process of coming to terms with one's sexuality tends to be more extended for persons defining themselves as lesbian or gay. On the other hand, the coming-out as non-heterosexual seems to occur earlier in life than it did some decades ago. Moreover, the accumulated demand for marriage should be over by now, so that the average age may be lower.

Gunnar Andersson's study further demonstrates that the frequency of divorce is considerably higher among homosexual couples than among heterosex- 
uals. Men who have registered partnership have a 55 percent higher frequency of divorce than heterosexual couples, and lesbians divorce twice as often as homosexual men.

Table 1. Partnership registrations yearly in the Nordic countries, 1989-2009. Number of couples

\begin{tabular}{|c|c|c|c|c|c|c|c|c|c|c|c|c|}
\hline \multirow[b]{2}{*}{ Year } & \multicolumn{2}{|c|}{ Denmark } & \multicolumn{2}{|c|}{ Norway } & \multicolumn{2}{|c|}{ Sweden } & \multicolumn{2}{|c|}{ Iceland } & \multicolumn{2}{|c|}{ Greenland } & \multicolumn{2}{|c|}{ Finland } \\
\hline & Female & Male & Female & Male & Female & Male & Female & Male & Female & Male & Female & Male \\
\hline 1989 & 62 & 267 & & & & & & & & & & \\
\hline
\end{tabular}

\begin{tabular}{lrrrr|}
1990 & 115 & 345 & & \\
1991 & 89 & 197 & & \\
1992 & 91 & 186 & & \\
1993 & 66 & 177 & 41 & 115 \\
1994 & 104 & 165 & 47 & 86 \\
\hline
\end{tabular}

\begin{tabular}{lllllllll}
1995 & 88 & 178 & 34 & 64 & 84 & 249 & & \\
1996 & 110 & 158 & 47 & 80 & 64 & 101 & 10 & 11 \\
1997 & 111 & 126 & 43 & 74 & 52 & 79 & 7 & 5 \\
\hline 1998 & 130 & 135 & 44 & 71 & 46 & 79 & 6 & 5 \\
1999 & 136 & 160 & 62 & 82 & 67 & 77 & 5 & 6 \\
\hline
\end{tabular}

\begin{tabular}{|c|c|c|c|c|c|c|c|c|c|c|c|c|}
\hline 2000 & 131 & 177 & 76 & 78 & 70 & 109 & 7 & 5 & & & & \\
\hline 2001 & 169 & 178 & 77 & 108 & 93 & 98 & 8 & 5 & & 1 & & \\
\hline 2002 & 163 & 140 & 78 & 105 & 105 & 106 & 4 & 5 & 1 & & 207 & 249 \\
\hline 2003 & 172 & 148 & 88 & 116 & 129 & 120 & 6 & 7 & & & 109 & 83 \\
\hline 2004 & 199 & 134 & 85 & 107 & 141 & 143 & 8 & 9 & & & 102 & 84 \\
\hline
\end{tabular}

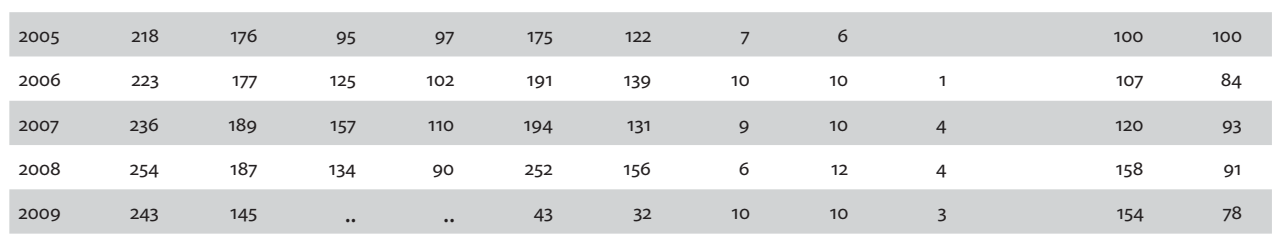

Sources: Denmark, Centralt Populations Register (CPR) 1989-1997, Statistics Demark 19982009; Norway, Statistics Norway; Statistics Sweden; Iceland, Statistics Iceland; Finland, Statistics Finland; Greenland, Statistics Greenland, Atuagagdliutit/Grønlandsposten 7/22/04. Note: Data from Denmark 1989-1998 show the number of Danish citizens who registered partnership divided by two and rounded off upward. Data from Denmark from 1999 onward show the number of couples. Data from Norway, Iceland and Finland account for the number of couples. Partnership data from Sweden show the number of individuals who registered partnership divided by two and rounded off upward. Swedish partnership statistics only accounted for persons who had permanent residency in Sweden, which 
may lead to odd numbers, and in Norway only those couples were accounted for in which the oldest partner had residency in Norway. Data from Greenland show the number of registered partners residing in Greenland 1 January 2009, divided by two, and the year they registered their partnership. A female couple known from the media, who registered in 2002 but has divorced, is added, as well as three couples registered in 2009 after a new search by Greenland Statistics.

On the other hand, the survey shows that same-sex couples in general follow the same divorce patterns as heterosexuals even if the levels are higher. Factors that usually tend to destabilise a relationship, as a higher age difference or a different ethnic origin within the couple, seem to have the same effect on homosexual couples as they have on heterosexuals. Correspondingly, the presence of children has a stabilising effect on both kinds of family, and higher levels of education also lead to lower risks of divorce. Homosexual couples in Norway and Sweden differ from heterosexual couples in all these ways. On the one hand, there is generally a higher age difference between the partners, they are more often of different ethnic origins, and they seldom have more children than heterosexual couples, which are all destabilising factors. On the other hand, they more often have higher education and they are, on the average, older when they register their partnership than heterosexuals are when they marry, factors which have a stabilising effect. That way, the population of same-sex couples displays three destabilising and two stabilising factors that could be expected to even out each other, but the fact remains that they have a considerably higher frequency of divorce. This should perhaps not be interpreted routinely as something tragic. Perhaps it is a sign that registered partnership has not yet become the disciplining institution some feared and others hoped for. If expectations of surrounding friends and families that couples should stick together are weak, relationships can perhaps become more dynamic and tendencies to keep together unhappy people less effective. ${ }^{6}$

\section{Why so ferw?}

The second characteristic that partnership statistics display, the comparably low number of partnership registrations compared to an expected ro percent of the marriage rate, needs further discussion. This question has been dealt with by several scholars before. Gunnar Andersson argues, as well as William Eskridge and Darren Spedale, that the lack of institutional support and expectations from the surrounding society contribute to the fact that same-sex couples register partnership or marry less frequently than different-sex couples. U.S. gay activist Paul Varnell claims that it is the novelty of the institution that is the reason, and that the numbers will rise when lesbians and gays get used to the idea. ${ }^{7}$ Lee Badgett uses statistical data from Belgium, the Netherlands, and Scandinavia to investigate how same-sex couples make use of the registered partnership (and, 
since $200 \mathrm{o}$ in the Netherlands, marriage). She does not analyse the changes over time, and she does not analyse the data according to gender, but she addresses the question why so few have made use of the laws. She is critical of many of the explanations put forth by earlier studies. Neither the novelty of the institution of registered partnership, nor the lack of support from the surrounding society are valid explanations, she argues.

Instead, Badgett runs the average rate of same-sex registered partnerships in each country against a number of known factors concerning the majority population, and convincingly establishes that no single factor in the general population can account for the lower rate of partnership registrations or marriages among same-sex couples. The only significant correlation she finds is a higher rate of same-sex partnerships and marriages in countries with a higher proportion of the population who regard marriage as outdated! However, there are a number of relevant factors within the lesbian and gay community itself, which are impossible to study with this method, and Badgett enumerates a number of such factors that she has observed during her interviews. Lesbian and gay couples may have found other ways to regulate their affairs and obtain recognition from the surrounding society; they generally have less children than straight couples; and there may be political objections to marriage among them. All these factors can contribute to the fact that a smaller portion of same-sex couples choose to register partnership or marry than different-sex couples. ${ }^{8}$

The first factor mentioned by Badgett is not studied in this book, whereas the two last are thoroughly discussed. But the discrepancy between the differentsex marriage rate and the same-sex registered partnership rate remains so high that questions about the actual numbers of potential same-sex partners must be raised. Gunnar Andersson puts the problem thus: If, as many say, homosexuals are Io percent of the population, and if the propensity of homosexuals to form and formalise their relationships is the same as that of the heterosexual majority, one would expect that the partnership registrations each year would be around a tenth of the corresponding numbers for heterosexual marriages. Instead, the figures for new partnership registrations per 100,000 inhabitants are less than I percent of the corresponding figures for heterosexual marriages in Scandinavia (see Table 2). So either the marriage habits of lesbians and gays are radically different from those of the majority population or they are significantly fewer than Io percent of the total population. ${ }^{9}$

The actual number of homosexuals in the population has been a matter of debate ever since the category "homosexual" was created and described toward the end of the nineteenth century. The first large inquiry into the matter was made by Magnus Hirschfeld in 1903 and 1904. 
Table 2. New partnership registrations and marriages per 100,000 inhabitants in Scandinavia and the Netherlands, 1989-2008

\begin{tabular}{|c|c|c|c|c|c|c|c|c|c|c|c|c|}
\hline \multirow[t]{2}{*}{ Year } & \multicolumn{2}{|c|}{ Denmark } & \multicolumn{2}{|c|}{ Norway } & \multicolumn{2}{|c|}{ Sweden } & \multicolumn{2}{|c|}{ Iceland } & \multicolumn{2}{|c|}{ Finland } & \multicolumn{2}{|c|}{ The Netherlands } \\
\hline & Mar. & Part. & Mar. & Part. & Mar. & Part. & Mar. & Part. & Mar. & Part. & $\begin{array}{l}\text { Differ- } \\
\text { ent-sex }\end{array}$ & $\begin{array}{c}\text { Same- } \\
\text { sex }\end{array}$ \\
\hline 1989 & 602 & 6,39 & 453 & & 1277 & & 467 & & 494 & & 610 & \\
\hline 1990 & 614 & 8,94 & 498 & & 471 & & 455 & & 500 & & 642 & \\
\hline 1991 & 604 & 5,09 & 447 & & 426 & & 483 & & 492 & & 632 & \\
\hline 1992 & 624 & 5,37 & 435 & & 428 & & 478 & & 466 & & 619 & \\
\hline 1993 & 611 & 4,67 & 435 & 3,62 & 389 & & 465 & & 486 & & 579 & \\
\hline 1994 & 680 & 5,18 & 458 & 3,07 & 388 & & 494 & & 488 & & 541 & \\
\hline 1995 & 666 & 5,1 & 481 & 2,25 & 381 & 3,77 & 464 & & 464 & & 528 & \\
\hline 1996 & 685 & 5,1 & 513 & 2,9 & 382 & 1,81 & 503 & 7,84 & 477 & & 550 & \\
\hline 1997 & 649 & 4,49 & 521 & 2,66 & 365 & 1,48 & 549 & 4,45 & 455 & & 546 & \\
\hline 1998 & 656 & 5 & 504 & 2,6 & 357 & 1,41 & 561 & 4,04 & 466 & & 566 & 19,23 \\
\hline 1999 & 667 & 5,57 & 526 & 3,23 & 402 & 1,63 & 566 & 3,99 & 469 & & 577 & 11,15 \\
\hline 2000 & 720 & 5,78 & 565 & 3,43 & 449 & 1,98 & 637 & 4,3 & 505 & & 564 & 10,09 \\
\hline 2001 & 684 & 6,49 & 509 & 4,1 & 402 & 2,14 & 524 & 4,59 & 478 & & 516 & 18,41 \\
\hline 2002 & 693 & 5,64 & 530 & 4,03 & 425 & 2,36 & 576 & 3,14 & 518 & 8,57 & 570 & 14,81 \\
\hline 2003 & 651 & 5,94 & 490 & 4,47 & 435 & 2,77 & 531 & 4,51 & 495 & 3,64 & 547 & 12,6 \\
\hline 2004 & 699 & 6,17 & 487 & 4,18 & 478 & 3,15 & 521 & 6,88 & 560 & 3,55 & 509 & 11,03 \\
\hline 2005 & 668 & 7,28 & 484 & 4,15 & 491 & 3,28 & 565 & 4,43 & 557 & 3,81 & 502 & 10,78 \\
\hline 2006 & 672 & 7,37 & 466 & 4,87 & 500 & 3,62 & 561 & 6,67 & 535 & 3,62 & 498 & 11,21 \\
\hline 2007 & 668 & 7,76 & 501 & 5,7 & 522 & 3,54 & 555 & 6,18 & 556 & 4,02 & 496 & 12,08 \\
\hline 2008 & 677 & 7,99 & 522 & 4,65 & 552 & 4,41 & 524 & 5,74 & 581 & 4,67 & 520 & 11,71 \\
\hline 2009 & 595 & 7,01 & 505 & 5,83 & 506 & 9,09 & 463 & 6,26 & 558 & 4,34 & 492 & 11,26 \\
\hline
\end{tabular}

Sources: Danish Central Population Register; Statistics Denmark; Statistics Norway; Statistics Sweden; Statistics Iceland; Statistics Finland; Statistics Netherlands.

Note: In the Netherlands, the column "Different sex" is based on the number of differentsex marriages until 1997, thereafter on both different-sex marriages and different-sex partnership registrations. The column "Same-sex" shows the rate of same-sex marriages per capita in the Netherlands until 2000, thereafter the rate of both same-sex partnership registrations and same-sex marriages. In Norway, "Marriages" comprise only different-sex marriages. From 2009 the column "Partnerships" shows same-sex marriages. In Sweden, "Marriages" comprise only different-sex marriages. The column "Partnerships" shows registered partnerships until 30 April 2009 and thereafter same-sex marriages.

He sent out 8,000 questionnaires to male college students and workers about their sexual inclinations. About half of them answered his questions and Hirschfeld concluded that 4 percent were attracted to both men and women and I. 4 percent were attracted only to men. ${ }^{\text {Io }}$ Hirschfeld's figures can be compared to the findings of a survey made in the United States at the beginning of the I990s, that I.3 percent of the women and 2.7 percent of the men had had a sexual partner of the same sex during the previous year, and that 4.I percent of the 
women and 4.9 percent of the men had had sex with a member of their own sex since they turned eighteen. ${ }^{\text {II }}$ These figures would correspond better to the rate of partnership registrations than the widespread assumption that homosexuals constitute ro percent of the population, a figure derived from the Kinsey report and publicised by the gay and lesbian movement in the I970s and I980s in order to prove that homosexuals were a large and invisible minority. ${ }^{\mathrm{I}}$

But what did Kinsey actually say? Alfred Kinsey and his team concluded that "Io percent of the males are more or less exclusively homosexual (i.e., rate 5 or 6) for at least three years between the ages of $\mathrm{I} 6$ and 55 " and they estimated that "4 percent of the white males are exclusively homosexual throughout their lives, after the onset of adolescence." ${ }^{{ }_{13}}$ The figures for females were much lower, but among unmarried women between 2 and 6 percent were "more or less exclusively homosexual" between the ages of 20 and 35 , while the same was true for less than I percent of the married women. Between I and 3 percent of the unmarried, and less than 3 in a thousand of the married women had been exclusively homosexual between the ages of 20 and 35 . Among the previously married women, between I and 3 percent belonged to that category. ${ }^{\mathrm{It}}$ Kinsey's research methods have since been questioned, and a possible bias in the sample has been discussed, but the general problem with all attempts to establish quantitative data for the presence of "homosexuals" in the population is the impossibility of determining the criteria for such a category. ${ }^{15}$

The discrepancy of the results from the various attempts to establish the incidence of homosexuality in the mean population reflects, in fact, the impossible nature of the question. The homo/hetero binary is something which Western culture has built much of its self-understanding on, but which would not be adequate for a global understanding of sexuality. ${ }^{16}$ Even in Western industrialised society the definition of what it is to be a homosexual is vague, and negative attitudes to homosexuality have forced most people to hide any desire for their own sex. In times and cultures different from today's dominating discourses, same-sex sexual behaviour has been part of the standard upbringing, but in still other times and cultures its practice resulted - and still results - in severe punishment. ${ }^{17} \mathrm{It}$ is thus impossible to say whether gays and lesbians in Scandinavia are more or less prone to register their partnership than heterosexual couples are to marry. For that reason, it is also probably impossible to establish the number of "homosexuals" in the population based on the number of registered partnerships. Finally, the incidence of partnership registrations varies regionally. According to our data, Denmark displays a significantly higher frequency of partnership registrations than the other Scandinavian countries, and in the Netherlands we see an even higher rate of same-sex partnership registrations or marriages.

In 1998, the Netherlands adopted a law on registered partnership similar to the Scandinavian ones, but with the important difference that the new marital 
status was also open to heterosexual couples. It turned out to be a popular reform, and after a few years, the heterosexual partnership registrations by far outnumbered those of same-sex couples (see Table 3 ).

Table 3. New partnership registrations yearly in the Netherlands, 1998-2009. Same-sex couples and different-sex couples

\begin{tabular}{|ccc|}
\hline $\begin{array}{c}\text { Same-sex } \\
\text { couples }\end{array}$ & $\begin{array}{c}\text { Different-sex } \\
\text { couples }\end{array}$ \\
\hline 1998 & 3010 & 1616 \\
\hline 1999 & 1757 & 1500 \\
\hline 2000 & 1600 & 1322 \\
\hline 2001 & 530 & 2847 \\
\hline 2002 & 547 & 7774 \\
\hline 2003 & 542 & 9577 \\
\hline 2004 & 583 & 10573 \\
\hline 2005 & 608 & 10699 \\
\hline 2006 & 619 & 10182 \\
\hline 2007 & 605 & 9945 \\
\hline 2008 & 611 & 10231 \\
\hline 2009 & 489 & 9001 \\
\hline
\end{tabular}

Source: Statistics Netherlands.

In the Netherlands, the formalities surrounding divorce are easier for those who register partnership instead of marrying, and such an arrangement is seen by many as a less serious step than traditional marriage. ${ }^{18}$ The fact that the Dutch partnership law was not a law reserved for a minority and the fact that differentsex couples soon saw it as a good alternative to marriage perhaps made it more popular also among same-sex couples. In 20or, the law that allowed marriage for same-sex couples was adopted and the Netherlands became the first country in the world to give exactly the same marital rights and benefits to same-sex couples as to different-sex couples. Those who already lived in registered partnership had the option to convert their partnership into marriage and those who lived in marriage could accordingly apply to have their marriage turned into a registered partnership. It then happened that the interest in registering partnership decreased among homosexuals but increased among heterosexuals. Many heterosexual couples had their marriages converted into partnerships, while many same-sex couples "upgraded" their partnerships to marriage. ${ }^{19}$ The number of same-sex partnership registrations fell dramatically after the introduction of gay marriage. It seems thus that there was a movement of lesbians and gay couples into full marriage, and of straight couples out of it. 
Diagram 1. Denmark: Number of new partnership registrations yearly 1989-2009. Female and male couples

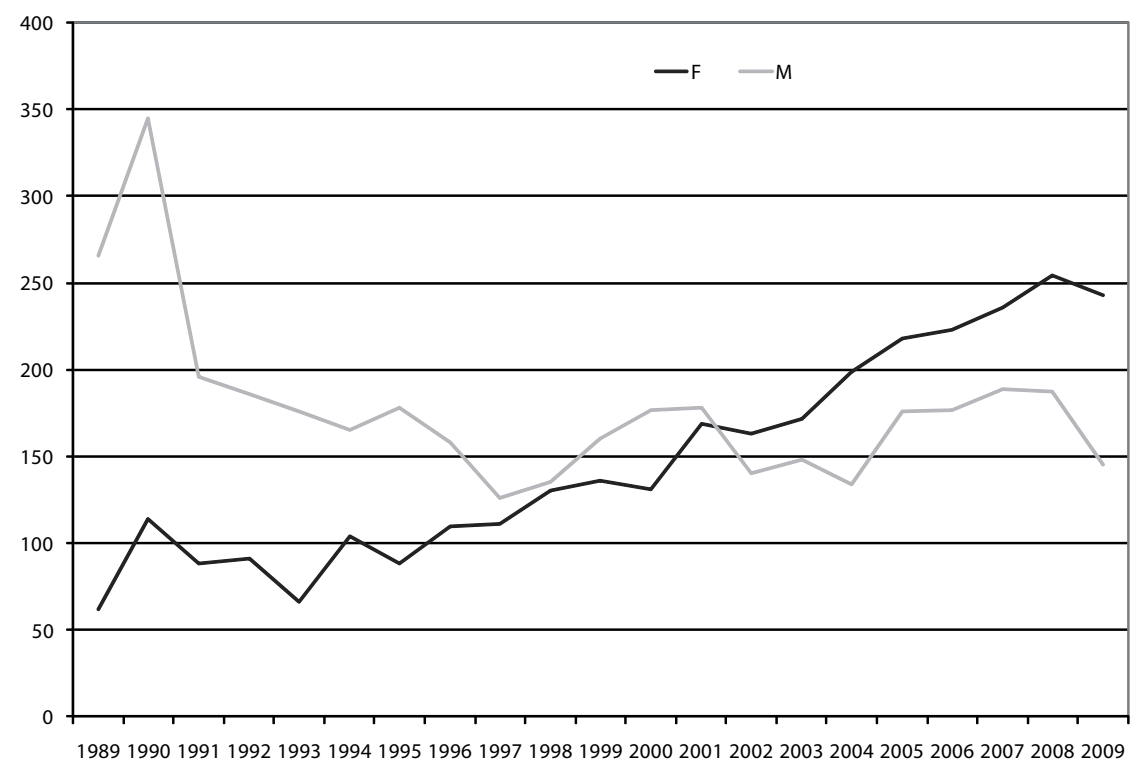

Sources: 1989-1997 Central Population Register (CPR); 1998-2009 Statistics Denmark. Note: Data from 1989 show the number of partnership registrations from 1 October, when the law became effective.

When marriage laws were made gender-neutral in Norway, Sweden, and Iceland in 2009-IO, all three countries chose a solution different from the Netherlands. Existing family legislation was adjusted to allow same-sex couples to marry in the same conditions as different-sex couples (and the question of church marriage was left to the religious congregations to solve). At the same time, the partnership law was abolished, with the effect that no new partnerships will be registered. Couples living in partnerships can transform their marital status to full marriage through a simple registration or through a new ceremony. From having had different sets of laws for same-sex and different-sex couples, Norway, Sweden, and Iceland now offer only one option for both, and the statistical columns of partnership registrations are closed. This was in accordance with what the gay and lesbian movement wanted. Their strongest argument was to push for equality before the law, and no wish seems to have been there to keep or extend a quasi-marriage arrangement such as registered partnership. The general trends in lesbians' and gay men's marriage habits do not seem to have been influenced by the fact that the registered partnership was replaced by marriage. The same-sex marriage rate is increasing at the same pace as partnership registrations did before the reform, and the difference between men and women remains (see Diagrams 2, 3, and 6). ${ }^{20}$ 
Diagram 2. Norway: Number of partnership registrations yearly 1993-2008 and same-sex marriages 2009. Female and male couples

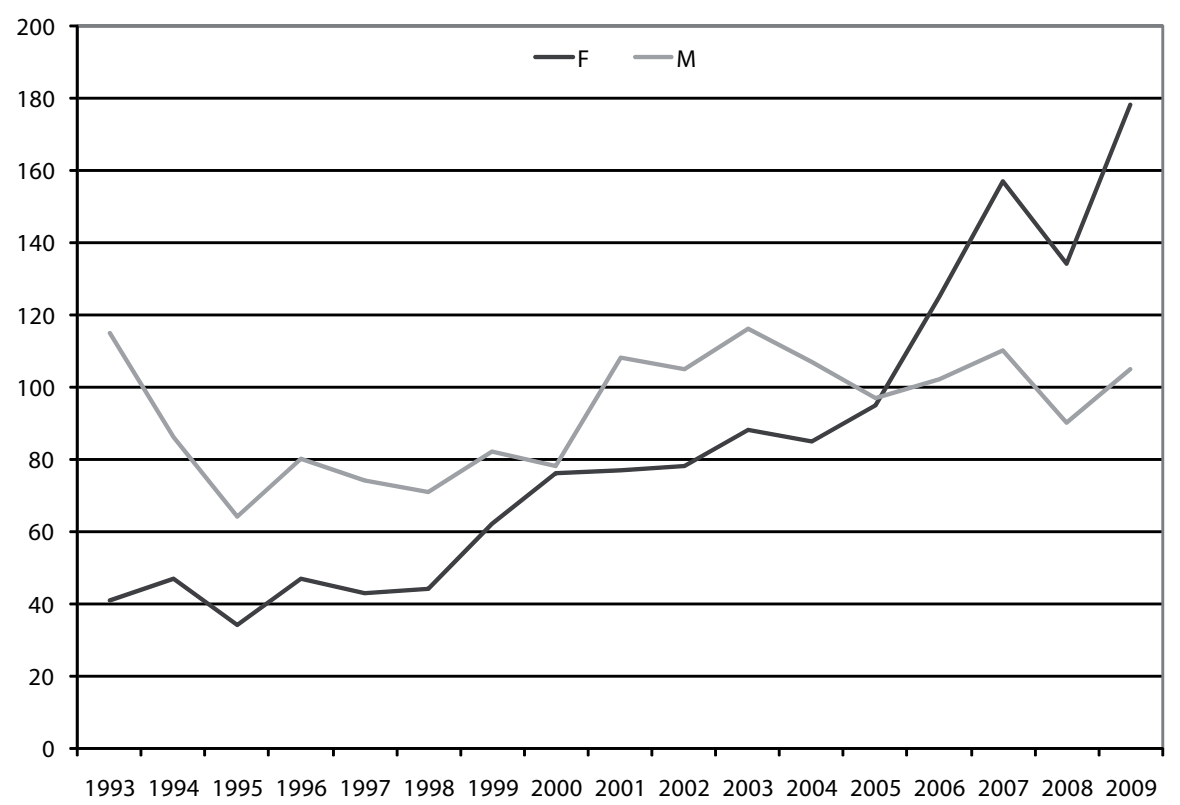

Source: Statistics Norway.

Finally, the low rate of partnership registrations per capita compared to different-sex marriages, suggests that I) there are either much fewer lesbians and gays in the Scandinavian population than the ro percent often put forth, built on a simplified interpretation of Kinsey, or 2) that their marriage patterns differ dramatically from those of the heterosexual majority, or 3) that the concept of "homosexual" is so vague and fluid that the head-count becomes meaningless. I would suggest an explanation with elements from all three hypotheses.

To begin with the last one, a growing body of research in the history of same-sex desire shows that the concepts and identities have constantly changed throughout history. ${ }^{21}$ Same-sex desire seems to have been present in all times and in all civilisations, but the social norms around it have varied greatly, and it has more often than not been intertwined with gender-transgressive behaviour and identities that render the very term "same-sex desire" if not meaningless, at any rate blurred and ambiguous. ${ }^{22}$ Even the Kinsey reports, indeed some of the most detailed and nuanced large studies of human sexual behaviour in Western society in our time, if read carefully, give little support to the establishment of a fixed category of homosexuals. ${ }^{23}$

Second, the marriage patterns among those who organise their lives in steady relationships with another person of their own sex lack the traditions and pres- 
sure from the surroundings to be pushed into marriage the same way as the heterosexual majority. Lesbians and gay men in Western society have a long tradition of celebrating their unions in various ways. They have staged ceremonies within their communities, with or without the inclusion of a religious blessing, and with or without their straight friends and family. The element of state recognition, however, is new to this community and so there are no traditions concerning it. Thus it is not to be expected that the gay and lesbian population will immediately fall into the same marriage patterns as the general population. ${ }^{24}$ Moreover, the practical consequences of marriage differ a great deal between different countries. Since the Scandinavian welfare systems are directed to the individual, and not to the couple, it has less consequences than in a country where the family remains the main recipient of welfare..$^{25}$

Third, it is to be assumed that the segment of the Scandinavian population with a lasting and more or less exclusive desire for a member of their own sex who organise their lives in a steady relationship with that person is lower than the Io percent put forth by the gay and lesbian movement, but that it is constantly changing, possibly growing. Many studies indicate that people tend to define their sexual identity differently according to the changing norms of society. ${ }^{26} \mathrm{With}$ the increasing importance of the transgender experience in the Western world, and its interconnectedness with genderised sexual cultures in Asia and Africa, it is to be expected that global sex will take on a slightly less rigid dichotomous character. This, combined with the increasing possibilities for same-sex couples, both technologically and discursively, to have children, indicates that the question of the "actual rate" of "homosexuals" in a population is obsolete. So the old ideological construct that io percent of all people are homosexuals needs to be reconsidered.

\section{Gendered marriage patterns}

The third characteristic of partnership statistics is women's reluctance to register at the beginning of the period and the higher interest among them to register at the end of the period. It is a tendency that is clearly seen in the three large countries with a long-enough history of partnership. In Finland the male-female ratio has been even from the outset (see Diagrams I-4).

From the beginning, Denmark, Norway, and Sweden displayed large differences in the number of registrations of female and male couples, and the number of female partnership registrations was less than half of the male registrations. The uneven distribution of partnership registrations levelled out somewhat but was significant until the year 2000, when the curves intersected. Now there is a significantly higher interest among female couples to register partnership in all three countries. The shift took place later in Norway than in Denmark, and the gender distribution in Sweden was fairly even between $200 \mathrm{I}$ and 
2004. How can we explain this development that follows more or less the same pattern in Denmark, Norway, and Sweden? To begin with, there was the widespread scepticism concerning marriage-like arrangements that held lesbians back early in the period. The ideological change in the I990s, when secondwave feminism was challenged by queer feminism and intersectionality, ironically made registered partnership more acceptable to lesbian feminists. ${ }^{27}$ As traditional feminism was accused of a one-dimensional view on gender inequality, overlooking differences in race, ethnicity, and sexuality among women, the theories of patriarchy were also discredited. Marriage was still seen as a petitbourgeois invention giving privilege to some at the expense of others, but it was no longer perceived as the foundation of patriarchy. As the concept of rainbow families spread in Scandinavia, it was given the status of a positive alternative to conventional families. From a queer perspective, lesbians and gays with children were seen as agents of change, as they fought for visibility and respect in an intricate web of welfare-state institutions designated solely for different-sex parenthood. The critique against gay marriage and registered partnership that is now voiced by lesbian feminists in Scandinavia is no longer formulated in terms of the struggle against patriarchy but is inspired by queer theory's resistance to mainstreaming and normalising.

The conditions for the debate within the gay movement and among lesbian feminists changed radically when the law on registered partnership became a reality. In countries where the law is under discussion - most obviously in the United States - the question determines the political agenda of gay and lesbian activists and leads to heated debates. A gay conservative wing in the United States gives priority to the introduction of full marital rights, which has sparked a fierce resistance from traditionalists in the U.S. From the other side of the political spectrum, gay and lesbian radicals use a wide range of arguments against the idea of gay marriage. They claim that gay marriage is the wrong priority, or that it is outright harmful to the gay and lesbian community because it stands for conservative principles of dependence and exclusion. ${ }^{28}$ In Europe, where laws on registered partnership and/or gay marriage have been introduced in a number of countries which have a strong gay and lesbian movement, the debate among activists is different. The question of registered partnership or gay marriage is often reduced to a question of personal choice or is seen as an important landmark in the fight for diversity.

Lesbian women's interest in having children is probably the most important reason for their changed behaviour regarding registered partnership. As seen in Table $\mathrm{s}$, the effect of the built-up demand for the reform, i.e. the high numbers of new partnership registrations during the first years after the law's introduction, was not at all visible for women in the countries that got the law first. But when Finland introduced the law on registered partnership in 2002, women displayed the same behaviour as men, with a boom of new registrations during the 
Diagram 3. Sweden: New same-sex unions yearly 1995-2009. Female and male couples

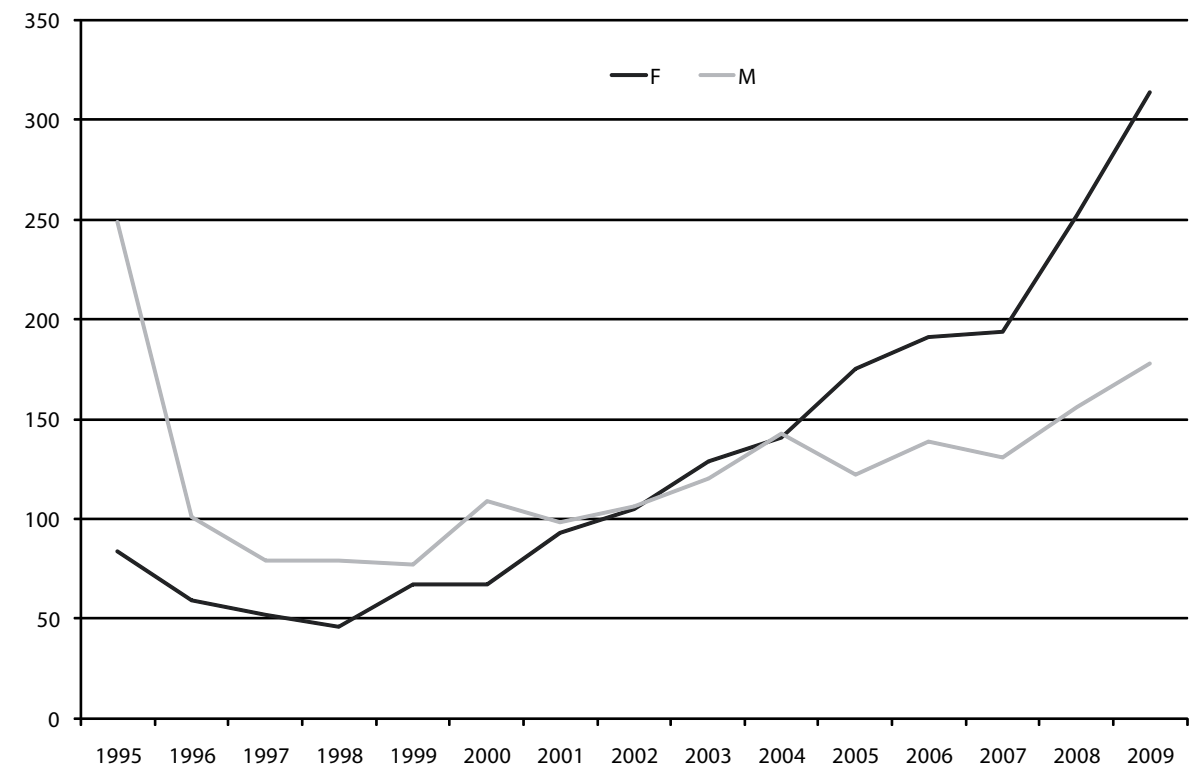

Source: Statistics Sweden.

Note: New partnership registrations yearly 1995-2008, new partnership registrations 1 January-30 April 2009, and same-sex marriages 1 May 2009-31 December 2009.

law's first year. Since the law was introduced in Denmark, Norway, and Sweden during the first half of the r99os, there had obviously been a shift in many women's attitude to it, most probably because the question of the custody of children had arisen. The Finnish law did not allow for stepchild adoption of children for registered partners, but demands for it were formulated by lesbian mothers in the public debate, and registered partnership was to a high degree perceived as a concern for both women and men. In her study of marriage resisters in Sweden, Anna Adeniji lets one of her fictional characters change her mind when her lesbian partner gets pregnant. Someone asks why, and she answers:

"The child, of course. It feels safer if we have it on paper. For [the pregnant girlfriend] Sanna it's probably also that we should do it because we can. She thinks that one should use the law that's there and not think too much about what's not there yet." ${ }^{29}$

Adeniji did not dwell further in her analysis of what difference pregnancy makes, probably because there was no ground for it in the numerous interviews she conducted..$^{3 \circ}$ It is, however, beyond any doubt that the lesbian (and gay) life- 
style has changed dramatically since the early i99os, and that children are now part of what a young lesbian woman can expect. In a study of lesbian feminism in the I970s, Swedish Gender Studies scholar Hanna Hallgren said one of the aims of her study was a will to know more about her "history as a lesbian," a will that is founded in her own experience of oppression and her will to change:

When I came out, I9 years old, in the beginning of the I99os, lesbian life looked very different from today. My self-understanding as a lesbian fresh from the closet included, for example, that I never would have children, because I was a lesbian. Also that I wouldn't be able to marry. During the r990s and 2000s, new laws have been introduced (for example concerning partnership and insemination) that have interacted with my lesbian identity and restructured my self-understanding. ${ }^{3 \mathrm{I}}$

The situation for self-identified lesbians has changed tremendously since the I990s as a result of new assisted reproduction techniques, but it is also - or mainly - a discursive change. Techniques for insemination were there long before the IVF techniques were developed, and with a known donor it was no problem for lesbian couples to have children. Legislation concerning insemination was, above all, important in sending signals to young lesbians that childraising was a possibility. Before the mid-I990s, many lesbians did have children, but it wasn't until the debate about lesbian motherhood (and gay fatherhood) became more intense at the end of the r99os that this practice grew and became more public. ${ }^{32}$ In Karin Zetterqvist Nelson's study of Swedish rainbow families from 2007 , several of the participants declared that they had felt they had to choose between their homosexuality and children when they came out to friends and family. One of them said that "that's the way it was before ... you dropped that if you chose to live out your sexual orientation then ... you often chose not to have children." And her partner added: "Yes, it wasn't until partnership came ... and it was Eva who made us visible.”'The partnership law, but also the press coverage when the Swedish singer Eva Dahlgren's registered partnership with designer Efva Attling became known, had thus been important for these two women. ${ }^{33}$

The number of male couples registering showed a slight decline after the initial boom, but now it has stopped decreasing and in most Scandinavian countries is slowly climbing, though the figures are still lower than the female ones. It has been suggested that the concern for the longest living partner in the wake of the AIDS epidemic was an incentive for many gay couples to register partnership in the early i99os, before new medicines radically increased life expectancy for HIV-positive persons. That may be true, but it has probably not influenced the overall figures. The number of male couples registering in Denmark, Norway, and Sweden dropped, in fact, until 1996-97, when the new medicines were introduced, and then it evened out in Denmark and increased in Norway 
Diagram 4. Finland: New partnership registrations yearly 2002-2009. Female and male couples

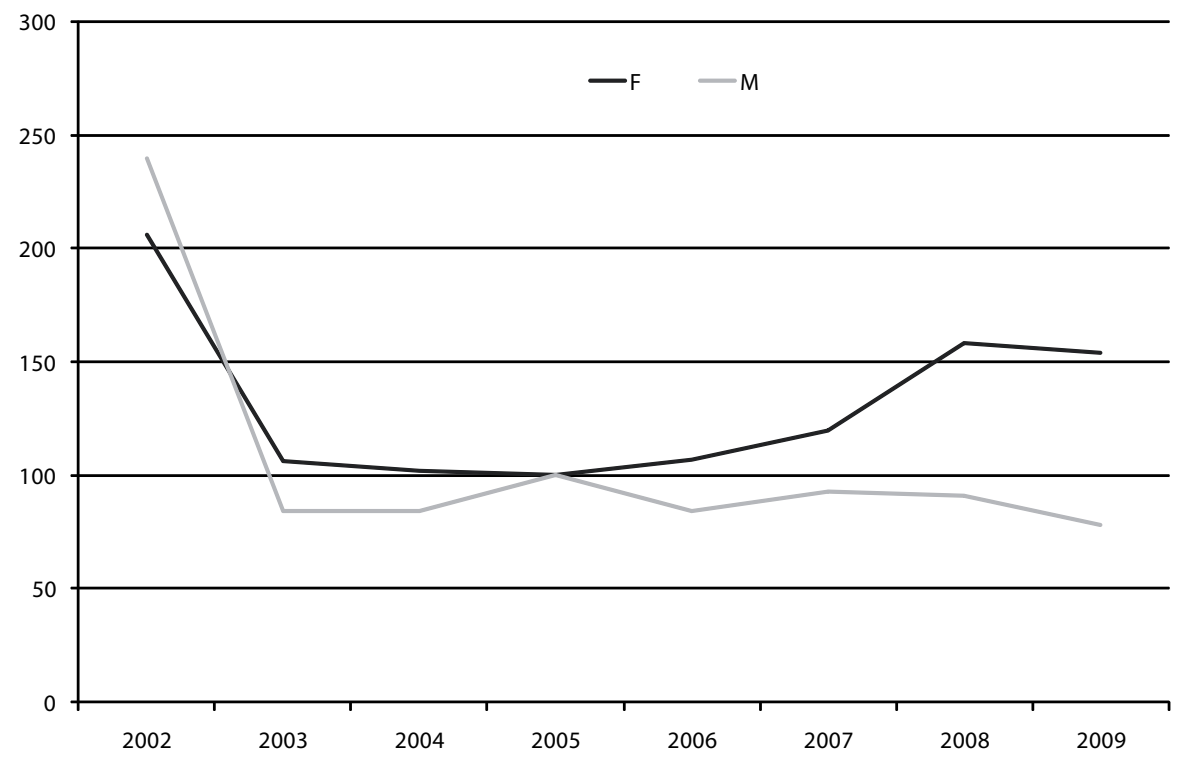

Source: Statistics Finland.

and Sweden (see Diagrams I-3). Most probably the AIDS epidemic played an important part in some individual couples' decision to register, but mattered little to the majority. Rather, there were other trends in society, such as the growing marriage business, that were more important.

If we compare the Scandinavian statistics with corresponding data from the Netherlands, we see that they both display a shift from the situation in which more men than women chose to register partnership. The differences between male and female registrations were never very large in the Netherlands, but the shift is nevertheless clear. During the short period between 1998 and 200I, when it was possible for Dutch same-sex couples to register partnership but not to marry, slightly more male couples were registered each year, and when marriage was opened to same-sex couples, men again took the lead. Since 2003, however, more women than men both register partnership and marry (see Diagram 5).

\section{Increasing interest}

The fourth characteristic I would like to discuss is the total increase of partnership registrations in Scandinavia during the last ten years (see Diagram 6). There may be two reasons for this, of which the first is purely mechanical. When 
Diagram 5. The Netherlands: New partnership registrations and same-sex marriages yearly 1998-2009. Female and male couples

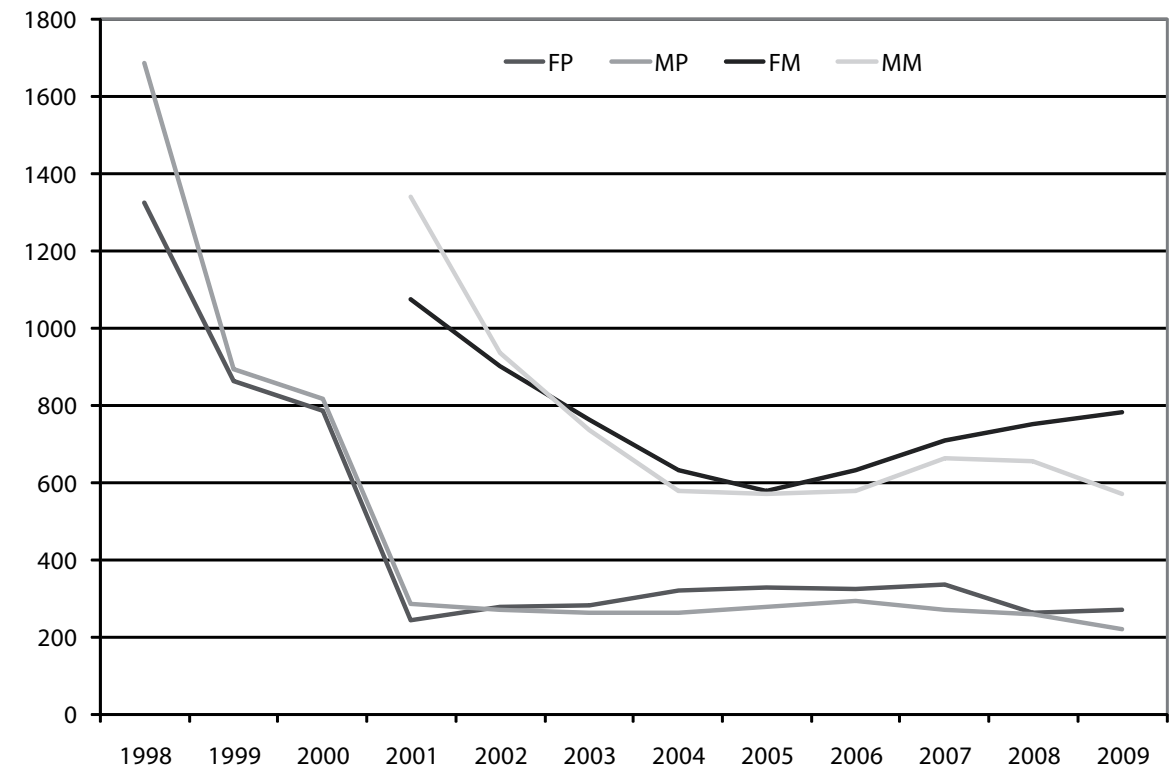

Source: Statistics Netherlands.

Note: $\mathrm{FP}=$ female same-sex partnership, $\mathrm{MP}=$ male same-sex partnership, $\mathrm{FM}=$ female same-sex marriages, $\mathrm{MM}=$ Male same-sex marriages. Data show only same-sex partnership registrations and marriages. Both forms of unions are open also to different-sex couples, which display considerably higher numbers of registrations and marriages.

the first group of lesbians and gay men had registered their partnerships during the first boom, the need for partnership was saturated. But after that, new generations of lesbians and gay men of the marrying kind have come of age, and the increase can be seen as a recovery. The other explanation is that marriage as such has become more popular, and the increase of the number of partnership registrations corresponds to an increase of the number of heterosexual marriages in the general population.

The Dutch figures, which include same-sex marriages as well as same-sex partnerships, display two peaks, one when the law on registered partnership was introduced in 1998 and one when marriage was made available to same-sex couples in 200r. The most striking difference between Dutch and Scandinavian data is that the will to formalise same-sex relationships is much stronger in the Netherlands than in any Scandinavian country. The Danish marriage frequency is the highest in Scandinavia, and that is also true for registered partnerships. The Dutch figures by far outnumber Denmark's when it comes to same-sex unions, but not concerning the different-sex marriage rate (see Table 2). 
Diagram 6: Rate of new partnership registrations per 100,000 inhabitants in Scandinavia and the Netherlands, 1987-2009

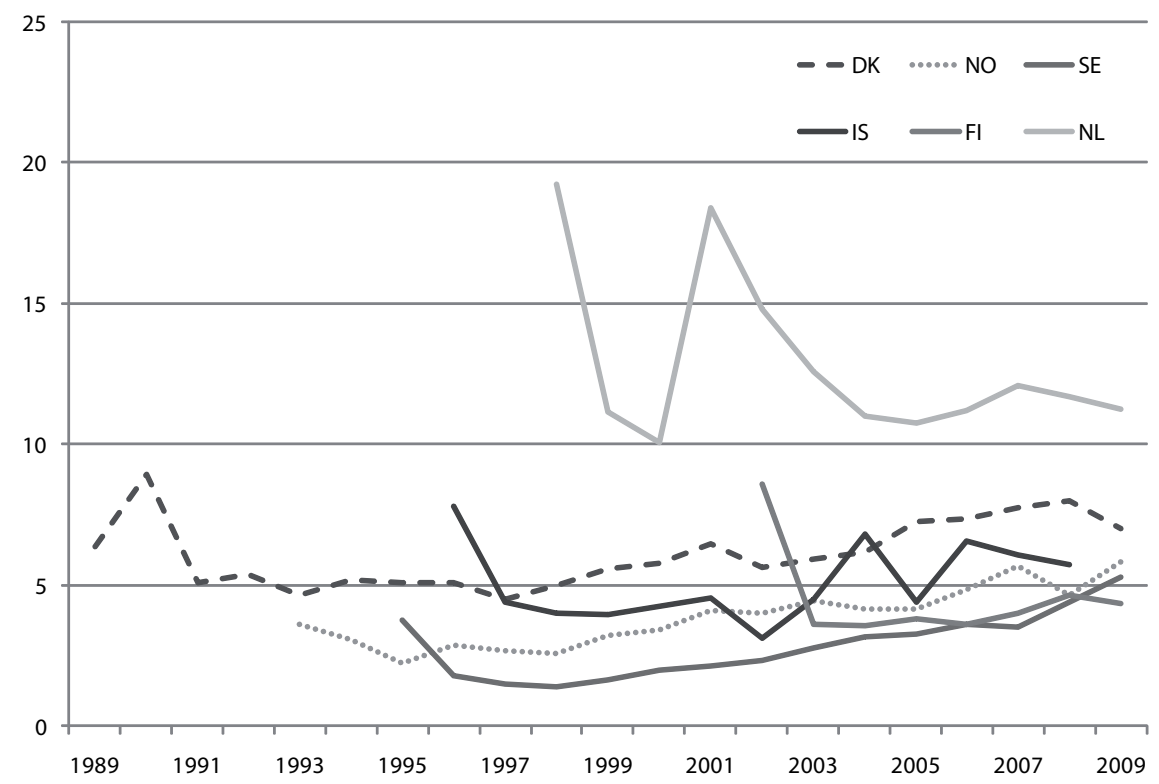

Sources: Danish CPR; Statistics Denmark; Statistics Norway; Statistics Sweden; Statistics Iceland; Statistics Finland; Statistics Netherlands.

Note: Dutch data from 2001 onward include same-sex marriages. Norwegian data in 2009 show same-sex marriages per capita only. Swedish data in 2009 are based on the number of registered partnership before 1 May and the number of same-sex marriages from 1 May onward.

If we return to Table 2, we can study the changes in the heterosexual marriage ratio in Scandinavia and the Netherlands, and we see that Denmark and the Netherlands have a higher tendency to marry than the other countries. Apart from the "marriage craze" in 1989 (when the widow's pension was going to be abolished, and thousands of couples hastened to marry to be covered by the old rules), Sweden has the lowest marriage rate in Scandinavia. It was declining until 1998 , but since then there has been a steady increase. The trends in the other countries are less clear-cut, though in all Scandinavian countries there is an increase in the marriage rate after the turn of the century.

The high marriage rate in Scandinavia may seem surprising, given the fact that most economic incentives to marry have been removed. The Scandinavian welfare state typically channels support to the individual and not to the family. In Sweden, the taxes on inheritance have been abolished, as well as the widow's pension, and in the other countries also there are fewer economic reasons to marry. ${ }^{34}$ It appears that the symbolic value attributed to marriage is enough 
to keep the marriage statistics high. Boosted by a developing marriage industry, the dream of a perfect marriage and its manifestation to society, family, and state seems to strengthen the idea of marriage in Scandinavia.

\section{Conclusions}

Marriage statistics of the kind presented here give only a rough idea of trends in the population, and their variations are due to factors that are hard to determine. Variations in general attitudes and fashion trends interact with material conditions such as changes in welfare schemes, class structures, and ethnic patterns. Qualitative research is necessary to explain why some choose to marry and others do not.

Nevertheless, the trends that stand out clearest in these tables and diagrams allow us to ascertain the following: I) Women who live in steady relationships with another woman have become much more inclined to register their partnership since the end of the I99os, when adoption of children gradually became an option for registered couples. That is true for all Scandinavian countries, and is probably due to the discursive and legal changes that have weakened the feminist marriage resistance and increasingly associate same-sex couples with childrearing. 2) The emergence of laws on registered partnership have in no way led to a decreasing will to marry among different-sex couples - which has already convincingly been shown by earlier research. 3) The low instance of same-sex registrations or marriages show that there are either far fewer lesbians and gays in the population than has been claimed by the gay and lesbian movement, or their marrying patterns differ significantly from the majority. I suggest an explanation that includes both these factors and also takes into account the fluidity of the category "homosexual." 


\section{Chapter Six: The next step}

The idea that the law on registered partnership was just the first step was used by both sides in the debate. Conservatives used it to call attention to a threatening possibility if the law was passed, while gay activists used it as a pledge to fight its limitations. "The next step is the Church," a headline announced in the Danish daily Politiken as the partnership law was voted through in Norway in 1993. The chair of LBL, Else Slange, said in an interview that the next step in Denmark must be to convince the Danish People's Church to let lesbians and gays marry in the Church. Other tasks for the Danish gay and lesbian organisation, Slange said, would be to work for free insemination for lesbian women in the national health system, and to change the law to make it possible for partners in registered partnership to adopt their partner's children. She concluded that the LBL looked forward to the next parliamentary session in order to make this "adjustment of the partnership law." Slange thus considered Church marriages to be a mere adjustment of the law, and that the following steps should be insemination for lesbians and adoption rights for registered partners. This was exactly what the opponents of partnership laws warned about. When the Swedish law proposal was debated in the Riksdag in 1994, the chair of the Standing Law Committee, Maj-Lis Lööw, tried to calm the opponents by assuring them that no such adjustments would take place. "Some ask if this is not only the first step. After this will come adoption, mutual child custody, and insemination," she said. "Demands have indeed been made concerning these issues. I can only answer for me and for the Social Democratic Party. This is the step. It is not the first step." ${ }^{2}$ Lööw's words have been quoted many times, and she has been accused of hypocrisy, since she ought to have known that the next steps would come. When she was interviewed in 2006 , she said it was necessary to make clear that what was voted upon that day was only the registered partnership law and nothing else. She felt public opinion was not ready for adoption at that time, and in her own party there were those who said they could accept registered partnership but not adoption. ${ }^{3}$

The steps some hoped for and some were apprehensive about were the abolition of the three major exceptions that had been built into the laws when they were first adopted. These exceptions can be summarised as: children, church, and citizenship. All three were rapidly challenged by gay activists and by an in- 
creasingly pro-gay public opinion. At the same time, however, the opposition to gay rights grew and became better organised. The exclusion from church weddings was both the most symbol-laden exception and the one that had the least practical or legal consequences. We note that Maj-Lis Lööw did not even mention it in her speech in the Riksdag.

The next step that LBL chair Else Slange hoped for was, in fact, to be the final one. The exemption from legally binding church weddings proved to be the most difficult to abolish. The Scandinavian National Churches are deeply divided over this issue, and the structure of these churches makes it difficult to disregard them. Historically important agents of state power, they claim a special status within the Scandinavian political landscape, and their decision-making bodies, the Church Meetings and the Bishops' Meetings, demand recognition on the same level as the national parliaments. The churches' autonomy prevents the state from forcing them to accept same-sex weddings in church, at the same time as they exert state authority by performing legally binding marriage ceremonies. Thus, the right to church weddings would be the last remaining difference between registered partnerships and full marriage, and it was generally solved by letting the churches themselves handle the question.

\section{Citizenship}

The first amendments to the partnership laws were, in fact, measures to further limit their scope. The Danish Folketing rapidly abolished same-sex couples' right to counselling by a priest in case of divorce in 1989, and in 1995 same-sex couples were excluded from the new law on parental rights (forcldremyndighed). Also, a law was passed in 1997 excluding lesbian women in registered partnership from assisted fertilisation by registered physicians. ${ }^{4}$ But after this initial period of restrictions, all changes in the Scandinavian partnership laws aimed to narrow the gap between heterosexual marriage and registered partnership. First, the provision that only citizens with residency had the right to register partnership was done away with. This provision seems originally to have been the result of a concern that lesbians and gays from all over the world would come to Denmark to marry. Vague ideas of mass immigration of gays figured in the discussions, but, as legal experts and politicians would soon acknowledge, it was a completely irrational fear. ${ }^{5}$ The immigration authorities in Denmark and several other Nordic countries already treated same-sex couples the same way as different-sex couples in matters of immigration, as the condition to get a permanent residence permit because of an intimate relation was no longer connected to marriage. Moreover, the legal effects of registered partnerships were necessarily limited to countries that had similar laws, so it was of no use going to Denmark to register and then claim any benefits in your own country because of that. In 1999 the Danish partnership law was amended so that foreign citizens could register 
partnership in Denmark if both had lived there for at least two years, and if at least one of the partners was a Danish citizen, residency was no longer required. Citizens in Iceland, Norway, and Sweden were given the same rights as Danish citizens in that respect. ${ }^{6}$ The following year, Sweden abolished the prerequisite that one of the partners should be a Swedish citizen, making it possible to register if one of the partners had had residency in Sweden for two years. For citizens of Denmark, Iceland, Norway, and the Netherlands it wasn't even necessary to have lived in Sweden for two years, only that at least one of the partners had residency.7 A case brought to the European Court of Justice in 200I, however, showed that registered partnership did not give the right to spousal benefits to the European Union's own employees, and the trend has indeed been that the scope of the law is limited to countries that have already introduced some form of regulation of same-sex relationships. ${ }^{8}$

\section{Parenthood}

"The next step" as defined by Maj-Lis Lööw in the Swedish Riksdag had to do with parenthood, and that was the most important exception to the definition of same-sex relationships as different from those of opposite-sex couples. The idea of lesbian women raising children was not new - already in 1955 the Swedish Supreme Court ruled that being lesbian was not a reason to deny legal custody of her children to a divorced woman. ${ }^{9}$ But there was no room for children in the official idea of the same-sex couple. It was construed as a life companionship involving sex, but not children. It was thought of as a barren, sterile relationship, while the young heterosexual couple was supposed to give birth to future generations. To some extent, young lesbians and gays in the I970s and I980s faced a choice between a life with children in accordance with society's norms or a lesbian or gay lifestyle without children. In fact, the dichotomy between childless queers and procreative heterosexuals was upheld both by the majority culture and by the post-Stonewall gay movement. Before Stonewall, it was generally accepted in homophile circles that some people married heterosexually and had children, but lived bisexually and had same-sex relationships, affairs, or brief sexual encounters outside their marriage. The gay liberation movement, however, demanded that lesbians and gays choose sides and renounce the bisexual lifestyle. The derogatory term "breeder" was reserved for the procreative heterosexuals, and lesbians and gays were henceforth discouraged from having children not only by society but also by other homosexuals. ${ }^{\text {To }}$

In the 1980s, however, this dichotomy was challenged when more and more lesbians and gay men invented different ways to combine a gay lifestyle with children. In Scandinavia, the "four-leaf clover family" became a new concept, as lesbian couples and gay couples began cooperating to get children. In the I980s many children were born with four social parents: two mothers and two fathers, 
or one mother and one father and two co-parents, depending on the family's internal agreements. ${ }^{\text {II }}$ When procreative techniques developed, however, women became increasingly free to have children without the involvement of (most often gay) men, and in the I99os there was a veritable lesbian baby boom. More and more lesbian mothers appeared in the media demanding legal rights for themselves and their children. Access to assisted reproductive technology and the right to joint custody and parenthood were their main demands, whereas the right to adoption more and more was conceived of as a male concern. ${ }^{\mathrm{I}}$

The legal regulation of gay and lesbian parental rights has involved legislation on adoption and on assisted reproductive technology, and those two areas have followed partly different lines of argumentation. The cornerstone argument in all debates on gay and lesbian parental rights has been and still is "the child's best interests," but the ground for evaluating the child's best interests becomes dramatically different depending on whether it concerns an existing child or one that is not yet conceived. The interests of a living child with two parents of the same sex can often be defined as the child's right to stay with the social coparent in case the biological parent dies. Consequently, the first amendments to existing laws on registered partnership involved the possibility of adopting one's partner's biological child, so-called stepchild adoption. But the legislation on these issues in the I99os was characterised by uncertainty and change. As already mentioned, the Danish partnership law was amended in 1995 in order to prevent same-sex couples from using the new law on child custody to transfer the custody of the child from the biological parent to her or his partner. ${ }^{\mathrm{I} 3}$ And in I997, when a new law on assisted reproduction was prepared in Denmark, some members of the Folketing discovered that the proposed law would allow lesbian couples to conceive children. They quickly prepared an amendment to the law proposal, which would reserve the use of assisted reproduction techniques for heterosexually married women. In the parliamentary debate, members from all political parties testified to the importance for a child to have both a female and a male parent, and the resulting law forbade medical doctors to perform assisted fertilisation on single women or women in registered partnership. However, midwives and nurses were not covered by the law, and in 1999 Danish midwife Nina Stork opened the Stork Clinic for lesbian women and single women. Nina Stork's clinic is still catering to many women, even though the prohibition for doctors to perform assisted fertilisation on single women or registered women was lifted in $2007 .^{.4}$

Negative attitudes to gays and lesbians having children was weakened throughout the I990s, partly because of the media coverage of seemingly healthy children of homosexuals, and partly because of lobbying efforts by the gay and lesbian movements. Policy-makers were especially influenced by the argument for the legal protection of children already living with two parents of the same sex. Unless the non-biological parent already had parental rights over the child, 
it risked being orphaned or transferred to a biological parent (or other members of the biological family, such as grandparents) against its own will in the case of the biological parent's death. Because of this, the right to stepchild adoption was the easiest to get through, and also it was deemed the most pressing issue by lesbian and gay activists. The Danish Parliament approved of stepchild adoption in 1999, but only from the third month after the child's birth, to allow time for a biological father to claim his parental rights. Iceland followed suit in 2000 , and Norway in 2002, whereas the Swedish legislators decided to wait until the whole issue of adoption had been investigated. ${ }^{\mathrm{IS}}$ In 2008 , Siumut, the ruling party in Greenland, proposed to update the Greenlandic law to harmonise it with the rest of the Nordic countries, and on I July 2009, stepchild adoption was allowed in Greenland. All 26 members present in the Greenlandic Parliament voted in favour of the proposal, but an earlier proposal to give lesbian couples access to insemination had been rejected and recommended for further investigation. ${ }^{16}$ In Finland, a parliamentary commission proposed that stepchild adoption should be made legal for same-sex couples, and after long considerations the law was voted through in Parliament with a clear majority of to8 votes in favour and 29 against. The law took effect on I September 2009. ${ }^{17}$

External adoption was the next "step." After extensive preparations, a Swedish Government commission in 200 proposed that the law on adoption be extended to allow same-sex couples the same right to be considered as adoptive parents as different-sex couples, thus allowing both stepchild adoption and external adoption. The law passed in Parliament after a long debate, with 193 votes in favour and 66 against. At the same time, it was decided that lesbian women should not be given access to assisted fertilisation in state-run clinics until the legal questions of custody in such cases were settled. The right to be considered as adoptive parents was hailed as an important reform for gay and lesbian couples, but it has since then largely been thwarted by the unwillingness of most adoption agencies to give up children for adoption by same-sex couples ${ }^{18}$ Full adoption rights have since been granted in Iceland (2006) and in Denmark (2009). ${ }^{19}$ In 2009, as Norway introduced the gender-neutral marriage law, full adoption rights were automatically given to married same-sex couples. ${ }^{20}$

In Finland, the question is still far from being dealt with by Parliament, but in May 2009 the Party Congress of the Swedish People's Party accepted a proposal to work for full adoption rights for same-sex couples. The question threatens to split the Swedish-speaking party, as the rural electorate in Österbotten (Pohjanmaa) strongly opposes the law. One of the representatives from Österbotten told the press that he feared the party would lose all voters from his district, that they would vote for the Christian Democrats. Another representative, from southern Finland, complained: "This is suicide for the SPP. Now the Finns can call us the homo-party." At the elections to the European Parliament two weeks after this, however, the SPP's share of the votes proved stable, and even 
rose from 5.7 to 6.I percent. Perhaps this is rather a sign of the inherent stability of a party that organises an ethnical minority, rather than a measure of the Swedish-Finnish population's gay-friendly attitudes. ${ }^{2 \mathrm{~T}}$

In 2003, the Icelandic Alpingi appointed a commission to investigate the living conditions for gay and lesbian citizens and propose ways to minimise discrimination. Its report, presented in 2004, suggested a number of measures, most important of which were the rights to adoption and assisted reproductive technology. These measures were adopted by the Alpingi in 2006 and, as has become customary with gay and lesbian rights reforms in Iceland, the new law took effect on Christopher Street Day, 27 June 2006..$^{22}$ Rules about cohabitation, adoption, and assisted fertilisation were all harmonised so that they would apply equally to same-sex and different-sex couples. In November 2007, a group of MPs presented a bill to the Alpingi proposing that a joint marriage law would apply both to same-sex couples and to different-sex couples, but after a short debate their proposal was rejected. Instead, a law was passed which allowed ministers of the Icelandic State Church as well as other religious leaders to perform legally binding registered partnerships in church. The new law took effect on 27 June $2008 .{ }^{23}$ Since then, there remains no difference between the legal effects of the marriage law for heterosexuals and the law on registered partnership for homosexuals in Icelandic legislation. The legal status of registered partnership was the one reserved for homosexual couples until 27 June 20I0, when the marriage law was opened to same-sex couples and the partnership law abolished. ${ }^{24}$

The rapid development of assisted reproductive technology has had a decisive effect on both the behaviour of same-sex couples wanting children and the legislators' attempts to control and regulate reproduction. In this area we witness a complicated interaction between the legislators and the agency of individuals and couples who use the new technologies to have children. Finland was, for a long time, the only country in Scandinavia where insemination was not regulated by law, and single women and lesbians from the other Scandinavian countries took advantage of Finland's lack of law in this area and went to Finland to become pregnant. A lively debate went on in Finland for several years, bringing up issues about family values, the best interests of children, and the need to regulate assisted reproductive technology. A law proposal was prepared in 2002 which would restrict the use of the new technologies considerably, but it was rejected by a majority of the Eduskunta. ${ }^{25}$ When the law on assisted fertilisation was adopted in 2006, it allowed access for lesbians and unmarried women to assisted reproductive technology in fertility clinics. As in Sweden and Norway, the Finnish law required that the identity of the sperm donor could be made known to the child at the age of eighteen, but without any consequences of legal parenthood for the donor. ${ }^{26}$ 


\section{Gender-neutral marriage laws}

After the 1999 decision to allow stepchild adoption, there was a pause in Danish initiatives to reform legislation for same-sex couples. In 200 a conservative coalition Government consisting of the right-of-centre liberal Left Party and the Conservative People's Party took power, with parliamentary support of the right-wing populist Danish People's Party, which exerts an influence in Danish politics that by far exceeds its I2 percent of the electorate. ${ }^{27}$ The view of the present Government on gay rights is that they are well taken care of by existing legislation, and it has routinely turned down all proposals from the opposition to extend the rights of people living in registered partnership.

Every year from 2003, different combinations of opposition parties have presented proposals to diminish the difference between registered partnership and heterosexual marriage. On several occasions, opposition parties have proposed that the Church of Denmark should be allowed to perform registered partnership ceremonies, but they have regularly been turned down. ${ }^{28}$ Likewise, proposals to allow stepchild adoption of a partner's child from its birth, and not from the age of three months, were repeatedly turned down by the majority. ${ }^{29}$

In 2008, the Radical Left Party presented a bill on a gender-neutral marriage law. Such a law would have two important consequences: allowing the church wedding of two persons of the same sex and making the rules of paternity in the Child Law applicable to children born of a woman married to another woman..$^{3^{\circ}}$ The Minister of Justice, Lene Espersen, from the Conservative People's Party, declared that the Government could not support the proposal because it could force the Church of Denmark to recognise same-sex marriage and because it had not considered some important consequences of a gender-neutral marriage law, like the legal status of the father. It was important to uphold the regulation that one could adopt one's partner's child only three months after its birth, because if a man claimed paternity within this time, it should be granted to him, she said. In the case of assisted fertilisation, she agreed, the situation was different. In Denmark, sperm donors are anonymous, and no biological father could legally be tied to the child. The Government was prepared to reconsider its stand on this point. However, it was decidedly against external adoption for same-sex couples. ${ }^{3+}$

Simon Emil Ammitzbøll, an openly gay MP from the Radical Left Party, declared his satisfaction that the Government would consider allowing stepchild adoption from the child's birth, and he could not see any reason why it would then not allow external adoption..$^{32}$ The right-wing Danish People's Party, on the other hand, displayed the most determined opposition to full marriage rights for same-sex couples, and it was about more than the right to be married in church. It was about the recognition of same-sex couples as equivalent to different-sex couples. Søren Krarup, a former minister in the Church of Denmark, represents the Danish People's Party in the Folketing and is one of its most in- 
fluential ideologists. He declared that the concept of marriage is reserved for a union of a man and a woman. At the end of the debate, the proposal was referred back to the Parliament's Standing Legal Committee (Retsudvalget) in order to investigate further the possibility of granting registered partners the right to adopt their partner's children from their birth. ${ }^{33}$

One year later Ammitzbøll, who by now had left the Radical Left Party and was an independent MP, put forth a new proposal that caused a more heated debate. This time, he wished to grant full adoption rights to same-sex couples, and a small group from the Left Party declared that they would support it, thus creating a small majority in its favour. The tone was considerably sharper than when gender-neutral marriage had been discussed a year earlier, and in the end, six MPs from the Left Party broke with their party line and voted for adoption, thus creating a slim majority for the proposal. ${ }^{34}$

\section{Norwegian politics}

Norway and Sweden both introduced gender-neutral marriage laws in 2009 and thus opened up the institution of marriage for same-sex couples. At the same time, both countries abolished the law on registered partnership. Seemingly parallel, gay rights politics in the two countries differ, however, in some important respects. Whereas Norway has based much of its gay rights debate on a broad survey of the life conditions for lesbians and gay men carried out in I999, the so-called NOVA report, Swedish policy-making has relied on a series of Government Commissions dealing with parenthood for same-sex couples. ${ }^{35}$ The Norwegian NOVA report, named after the institute that published it, was commissioned by the Social Democratic Minister for Children and Family Affairs Sylvia Brustad and published in January i999. It was a survey based on a sample of lesbians and gay men, and showed that their overall life situation was difficult. Particularly one of the findings, that one out of four young lesbians and gay men had attempted suicide, was widely circulated and generated strong feelings that something had to be done quickly. Another finding from the report, that lesbians and gays suffered more in rural areas, was apt to influence parties with a rural electorate, parties that usually held conservative values in family politics. ${ }^{36}$

In January 2000, two celebrities chose to come out of the closet, which slightly changed the political climate in Norway. The well-known author and former Social Democratic Minister of Justice Anne Holt registered a partnership in the Norwegian Embassy in Stockholm and shortly afterwards informed the media. She had been a well-established author of crime novels for years, and her lesbian heroine Hanne Wilhelmsen had become a role model for thousands of lesbians in Norway and abroad. The other celebrity to come out was Per-Kristian Foss, who declared that he was gay shortly before he was elected 
chair of the Right Party's Oslo District. Foss was elected unanimously and was warmly supported by his party fellows - an attitude very different from the one that met Wenche Lowzow when she came out to the same Party in 1978. Foss lived in a long-term relationship with the CEO of one of Norway's largest companies, and when he later became Minister of Finance the possibility of conflicting interests was sometimes brought up for discussion. Many people agreed that the institution of registered partnership made it easier to handle the situation of conflicting interests. ${ }^{37}$

In March 2000, the Christian Democratic coalition Government resigned after a defeat regarding energy politics and was succeeded by a Social-Democratic minority Government. One year later, the new Government presented a Message to Parliament (Stortingsmelding) in which it vowed to work for a number of concrete measures to improve the life situations for lesbians and gay men. In the parliamentary debate, all speakers agreed that something had to be done. The Christian People's Party was again criticised for promoting homophobia, but its representative repeated that he and his party respected homosexuals, even if they had differing views on child adoption and insemination. One thing in particular was debated: whether the Church of Norway should keep its right to refuse employing practicing homosexuals in so-called consecrated po${\text { sitions. } .^{3}}^{3}$

The Labour Party lost the elections in 200I and were again replaced by a Centre Right Government under Kjell Magne Bondevik from the Christian People's Party in the fall of 200r. It was the beginning of a four-year period of conservative politics, which slowed down gay rights reform work, since the new Family Minister Valgerd Svarstad Haugland was opposed to gay adoption and lesbian insemination. In 2002 she caused a commotion in Norwegian media by publicly criticising Anne Holt and her partner Tine Kjær for having received an insemination abroad. "They know perfectly well what Norwegian law says, and they know perfectly well what they've done," she told the press. Tine Kjær replied angrily: "I perceive your attack on me as a pregnant woman as un-Christian and hateful ... I hope that your statement, in which you insinuate that my pregnancy is unlawful, was a slip of the tongue. At any rate, I expect an unreserved apology." The Prime Minister defended his Family Minister, who did not issue any apology, but this affair again opened up the debate on insemination for lesbian couples, so, paradoxically, the anti-gay stance of the Government gave new life to the debate on gay marriage..$^{39}$

In 2003, Bondevik's Government presented a proposal to implement the European Community directive on equal treatment in employment and education. The law that resulted prohibited discrimination on grounds of sex, ethnicity, sexuality, disability, and age, and all parties except the Progress Party were behind it. ${ }^{\circ}$ In the spring of 2005 , an extensive Anti-Discrimination Law was enacted, again following the directives from the European Union. Norway is 
not a member of the European Union, but since it has signed the EEA (European Economic Area) agreement it has chosen to implement most of the EU legislation. ${ }^{4 \mathrm{I}}$

After the 2005 elections, the new Centre Left coalition Government energetically pushed for gay and lesbian rights. The leader of the Socialist Left Party, Kristin Halvorsen, had not forgotten her own commitment to gay marriage. It was, in fact, one of the headings in the "Soria Moria Declaration" - named after the high-altitude hotel in which it was drawn up - where the new coalition Government laid out its agenda. Among other things, it pledged to support lesbian and gay organisations, actively follow up on lesbian and gay citizens' living conditions, and work for changes in the marriage law that would give the same rights to lesbian and gay couples as a marriage between two of the opposite sex. ${ }^{42}$

When the bill of "joint marriage law" (felles ekteskapslor), as it was now called, was debated in the Lower House (Odelstinget) of the Storting on II June 2008, the spectator stands were filled with gay and lesbian activists, and in the front row were Wenche Lowzow and her partner Kim Friele. It was the first time Lowzow was back in the Parliament building since she had been forced to leave politics by the generalised homophobia in the Right Party twentythree years earlier. ${ }^{43}$ The law proposal before the House had wide-ranging consequences. It would automatically give same-sex couples the right to joint adoption of children and assisted fertilisation with the same conditions as heterosexual couples. ${ }^{44}$ The tone in the debate was entirely different from what it had been when registered partnership was discussed sixteen years earlier. There were no sweeping anti-gay remarks, and even the opponents to the new law repeatedly claimed that they respected lesbians and gays and that they were against discrimination. Many speakers took the opportunity to bring up the Christian People's Party's poor record in gay and lesbian rights issues. The party had been opposed to the decriminalisation of homosexuality in 1972, it had been against the anti-discrimination clause in I98I, and it voted against the law on registered partnership in I993. Its representative Bjørg Tørresdal explicitly apologised for these past actions and wished that the debate would be about the present decision, not about things in the past:

I am not proud of everything the Christian People's Party has said about homosexuals over the years. There are, without doubt, many who have been hurt. I am sorry for that. At the same time, one should respect the fact that the Christian People's Party, like all other parties and society at large, has changed its views on both homosexuals as such and their right to live in binding relationships. ${ }^{45}$

The Christian People's Party's main argument against the new law was that existing laws regulating heterosexual and homosexual cohabitations were 


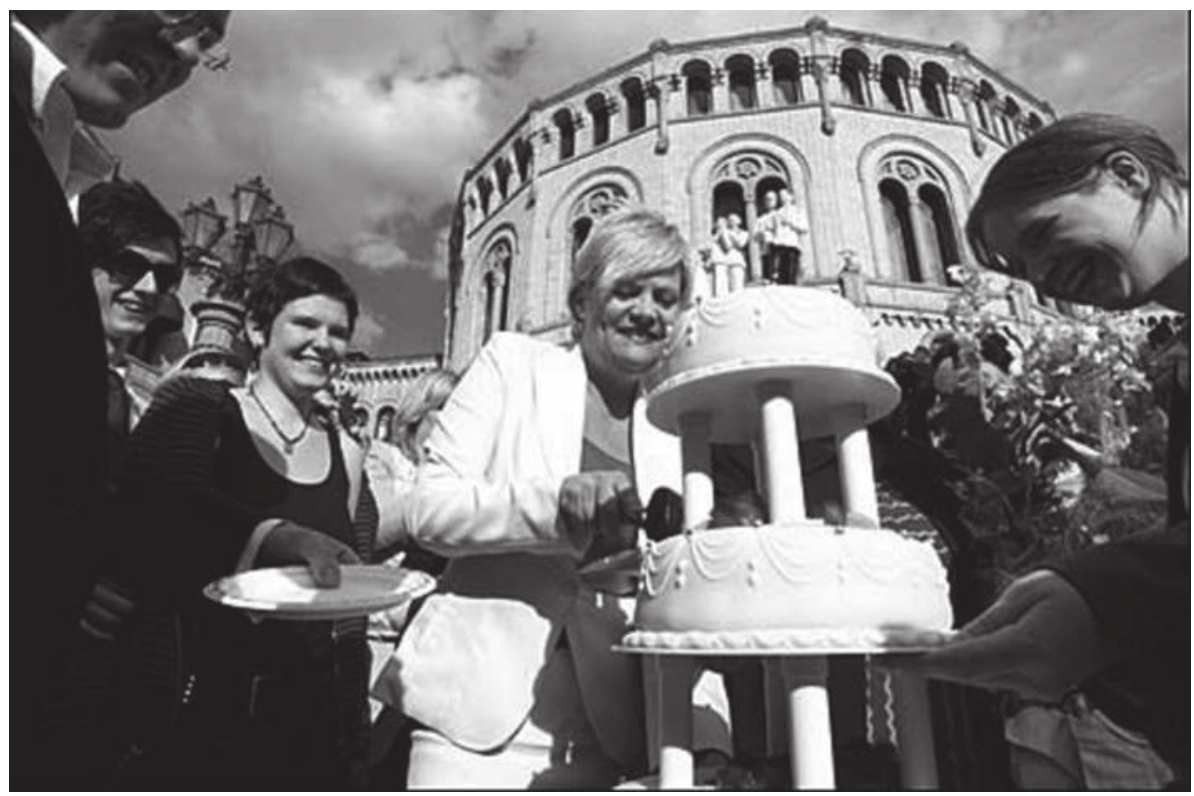

When the Joint Marriage Law had been carried by the Norwegian Parliament, the leader of the Socialist Left Party, Kristin Halvorsen, cut a giant wedding cake in front of the Storting building. Photo: Cornelius Poppe/SCANPIX.

satisfactory. A joint marriage law for both kinds of relationships could bring ethical problems concerning the rights of children. Another speaker heckled Tørresdal for the fact that the Christian People's Party, which had fiercely fought against the law on registered partnership in 1993, now was its staunchest defender. Tørresdal answered that "all parties in this House have had opinions about the partnership law. Those who have changed their opinion most are those who today claim that the partnership law is discriminatory. The Social Democrats said something completely different when the partnership law was adopted." ${ }^{6}$

The opponents of the law were speaking for the record, to state their opposition to the law in a situation where it was clear that it would pass. The speakers from the Centre Party and the Right Party declared their respect for the minority in their party groups who were against the law for religious or other reasons. Those who spoke on behalf of these two parties were from the majority that supported the new law, and its opponents refrained from speaking. The speakers elaborated on classical liberal arguments about equality before the law and the conservative argument that a joint marriage law would indeed strengthen the institution of the family. The Conservative spokesperson for the proposal, Olemic Thommessen, made an effort to appease the opposition within his own party, first by declaring his respect for their conviction, and then to present the 
advantages of the new law in terms of its neutrality and of its stabilising effects. "It is my belief that through this adaptation to a new time we will strengthen committed relationships and the family as a cornerstone in our society," he said, and reminded the Storting that "the wish to build family relations, a family framework for a life, is very, very important for the Right Party." In the 2009 debate, all speakers in favour of the joint marriage law, conservatives as well as liberals and socialists, used the argument that gay marriage strengthened the family. ${ }^{47}$

The liberal Left Party had presented its own proposal about a compulsory civil marriage that would solve the problem of the Church's attitude. The Left's spokesperson, Trine Skei Grande, knew well that there would be no majority for her party's model, but she and her party group insisted on carrying it to a vote. (It received only eight votes.) Toward the end of her speech, she delivered an unusually clear statement of the normalising expectations that were an important part of the reform, and it is worth quoting in its entirety:

I remember the first really open homosexual I got to know. I was seventeen or eighteen years old and I was active in the Young Liberals (Unge Venstre), which always had their quota of queers, and I remember that we discussed "Why does it become so exaggerated? Why do you become so different?" I remember that he said: "When you have to break with society and with your network, you are no longer bound by the norms of society." It was a real epiphany.

What we will do this day is that we, in reality, will say that all should be treated equally, but it will also mean that we can expect that the community's norms shall apply to all. The norms of our community say that now we expect that everyone shall have the possibility to enter a binding commitment, but then we also expect that the community's norms are there.

In reality, this statement was a way of saying that if society gives marriage rights to lesbians and gays, it has a right to expect them to behave. "Why does it become so exaggerated? Why do you become so different?" were questions posed by a young liberal woman, presumably to an effeminate gay man, as she was provoked by his flamboyant manners or those of his fellow queers. Now, many years later, she used his answer to make the point that if society assimilates lesbians and gays into its legislative framework, it can also expect a more normal behaviour. It was perhaps an argument that was aimed at the more conservative forces in the country, those who disapproved of the norm-breaking behaviour of queers, but in fact it confirmed one of the arguments that queer criticism had formulated against gay marriage..$^{4}$

The voting on the new law was a complicated procedure, as there were many counter proposals and additional suggestions, but the law in its entirety was carried with 84 votes in favour and $4 \mathrm{I}$ votes against. The reading in the Upper 
House (the Lagting) six days later was a pure formality, and the arguments put forth were the same as in the Lower House. It was carried by 26 votes in favour and I4 against, and thus sent to the King for signing. ${ }^{49}$ On I January 2009, the Norwegian joint marriage law became effective, making Norway the first Scandinavian country and the sixth in the world to introduce a gender-neutral marriage law. The initiative in marriage rights for gays and lesbians had obviously slipped out of Scandinavia and onto the global stage..$^{\circ}$

The question of church marriages, however, has been less favourably treated by the Church of Norway. Whereas different dioceses have different opinions whether persons who have registered partnership or married someone of their own sex can be ordained priests, the unity of the church is preserved on the question of same-sex marriages in church. A same-sex couple can marry in the town hall and then go to church to have their union blessed, but the Church of Norway emphasises that a marriage and a blessing in church are different

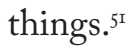

\section{Swedish lobbying}

In Sweden, the idea of gender-neutral marriage was discussed by a Government Commission, which delivered its report in 2007 , suggesting that the law on registered partnership be abolished and the question of marriage in church be left to each congregation to decide..$^{22}$ The RFSL protested, claiming that this would give religious congregations the right to discriminate against same-sex couples, but in reality they were prepared to accept the proposal. Important steps toward a gender-neutral marriage law were taken when one party after the other decided to support the idea, and the lobbying efforts by RFSL were not negligible in that process.

In an interview in September 2009, when Sweden's gender-neutral marriage law had been in place for a little over two months, the chair of the RFSL, Sören Juvas, described how his organisation had worked for gay marriage over the years. Juvas himself and his partner Daniel had been married in an "illegal" ceremony in Visby on 1o July 2007, which was the year RFSL intensified its lobbying efforts.53 "It was an effort in which many were involved," he said about the lobbying for the new law, and mentioned a number of gay-friendly politicians from different parties. "But you have to remember that such a person as Yvonne Andersson from the Christian Democrats was also very important for this work, since she, in a way, characterised the opposition, and made it very clear why it was important." ${ }_{54}$ Most important, according to Juvas, was the lobbying effort toward the two largest parties, the Social Democrats and the Moderates. Smaller parties such as the Environment Party, the liberal People's Party, and the reformed socialist Left Party were already committed to the kind of gender-neutral marriage law that RFSL wanted. 
The Social Democrats have always been a very broad party, harbouring a wide number of opinions. During the interview, Juvas stressed the importance of appealing to the entire party, and he described how the RFSL had acted to influence the Social Democrats:

We wrote a member's motion for the Social Democratic Party Congress and asked Urban Fransson to deliver it, since he was a local politician from [the far north district of] Arjeplog ... It was important that it didn't become a question for the big cities. He was a local government commissioner who was completely open about his sexual orientation, unbelievably popular within the party, and enjoyed lots of support in his home district. 55

The RFSL had good contacts with openly gay and lesbian politicians with influence in all parties except the Christian Democrats. Some of them had been activists in the RFSL before entering politics, and the number of openly gay and lesbian members of Parliament and various municipal assemblies grew. At the same time, the number of gay-friendly straight politicians grew year after year. But the situation within the right-of-centre coalition Government was delicate, since it depended on the support of the Christian Democrats. The question was whether the Christian Democrats would be prepared to leave the Government over this issue. From the RFSL's perspective, it was important to get binding promises from all the other parties before the September elections of 2006. In August of that year all the party leaders were invited to a debate on LGBT issues during the Stockholm Pride celebration. RFSL chair Sören Juvas described that particular debate as a decisive moment for the campaign: ${ }^{56}$

We did not accept anybody but the party leaders and promised that there would be an empty chair on the scene for those who didn't show up. That was very annoying to the whole Social Democratic movement, because their party leader Göran Persson refused to come, and when he refused, the whole opposition came running. ${ }^{57}$

The absence of Social Democratic party leader Göran Persson was, officially, because he was overworked and on vacation, but Sören Juvas did not believe it: "It was his own choice. They said that he was on a holiday and that he was to be pitied, but that was rubbish ... He just didn't want to come, that's all." The debate among the party leaders was decisive, Juvas said, because it was then that the gay and lesbian movement got the necessary binding promises from the highest level..$^{8}$

After the September elections, there was, in fact, a change of Government. Because of a number of binding resolutions from their party congresses, the Moderates, the Centre Party, and the Liberal People's Party in the new Government were committed to a gender-neutral marriage law, but to remain in power 
they depended on the support of the Christian Democrats. The solution to keep the Government together was that it presented a proposal on a reformed marriage law which did not include the possibility of marrying same-sex couples. The Moderates, the Centre Party, and the People's Party then presented a joint party bill on a gender-neutral marriage law. Together with a number of members' bills from the other parties, the whole issue was referred to the Standing Committee on Civil Law (Civilutskottet), and its report back to the Riksdag became the law proposal to vote on. It was an exceptional proceeding, which was, in fact, the same way the law on registered partnership had been dealt with fifteen years earlier..$^{59}$

The parliamentary debate in Sweden was, in a way, less interesting than the one in Norway some months before. Since there was no right-wing populist party represented in the Swedish Parliament, the only party that consistently opposed the law was the Christian Democratic Party. Its speakers repeatedly expressed their respect for gay and lesbian citizens and for their right to choose their lifestyle. They supported the right of lesbians and gays to have their relationships recognised by the state, but they claimed that the existing partnership law was satisfactory. Like the Norwegian Left Party, the Swedish Christian Democrats proposed a compulsory civil union. They wanted the Church to relinquish its marriage right, and to let each religious congregation decide whether they wanted to perform blessings and ceremonies without legal consequences. By this proposal, the Christian Democrats wanted to keep the word "marriage" for heterosexual couples by simply weeding it out of civil legislation. The State would thus not recognise same-sex unions as marriages.

Another important difference between the Norwegian and the Swedish debate was that the rights to insemination, assisted fertilisation, and adoption were already granted to same-sex couples in Sweden by separate laws. In Norway, the interest of the child was brought up in the Storting debate, whereas in the Swedish Riksdag it was pointed out several times that these questions had already been dealt with. The only addresses that diverged from the general consensus were those of the Christian Democrats, arguing for a separate cohabitation law and civil marriage, and those of the Left Party wishing that the religious congregations' right to refuse to marry would not have been inscribed in the law. A short debate between the Left Party and the Christian Democrats ensued, in which the Christian Democrats predicted that a leftist Government in the future might take away the right to refuse to marry. But otherwise the consensus was overwhelming. The situation in the Riksdag was unusual: six out of seven parties agreed on the proposal, and at the final vote, only 2I Christian Democrats and one representative from the Centre Party voted against it. There were $26 \mathrm{I}$ votes in favour from the other six parties, and I6 abstentions, one from the Christian Democrats and the rest from the Moderates. ${ }^{60}$ 
On I May 2009, the Swedish gender-neutral marriage law took effect, and the law on registered partnership was abolished. After that date, those living in registered partnership had the choice of converting their registered partnership into a full marriage or to continue living as registered partners, but no new partnership would be registered. Thus the marital status "registered partner" will gradually vanish from Swedish society. A small group of people will probably choose to continue to be registered partners, a vestige of the brief historical period, I995-2008, in which same-sex couples had an exceptional status in Swedish civil law. ${ }^{6 r}$ The only aspect of full recognition of same-sex couples that was unresolved was the question of church marriage. The political solution was to put the Church of Sweden on equal footing with the other forty congregations enjoying the right to perform legally binding marriages in Sweden and let it decide for itself. On 22 October 2009, the Church of Sweden decided to allow same-sex marriages in church. The decision was made by the Church Meeting after intense discussions over more than a decade, but since the new marriage law took effect the question had become pressing. The decision was to allow individual priests the choice of refusing to marry same-sex couples, but the rector then had to appoint another priest to perform the ceremony. It was carried by I78 votes in favour and 68 against, with only three abstentions. ${ }^{62}$

\section{Consensus in Iceland}

In Iceland, the gay marriage law went through swiftly and without any opposition. The law from 2008 that for all practical purposes had made the existing law on registered partnership equal to marriage had prepared for the reform. During the first reading of the proposal, speakers from all political parties offered their support to a joint marriage law, and some took the opportunity to remind the Alpingi of the history behind it, complaining that the joint marriage law had not come earlier. The only reservation was voiced by the conservative Independence Party, which insisted that nobody should be forced to perform same-sex wedding ceremonies against their conviction.

One particular trait of the Icelandic political process in these matters has been the broad support behind all the steps toward gay marriage. Activists and politicians were keen on avoiding a polarised debate, and they did not allow one party to monopolise the question. All spoke respectfully of the Church and some thanked it for an open and constructive dialogue. At the second reading of the proposal the spokesperson of the majority in the Standing Committee that had prepared it, made it clear that they intended to respect individual priests' right to refuse to marry same-sex couples. The stand of the Icelandic Church is still not resolved, but individual priests are free to perform legally binding church weddings, and others are free to refuse. At the third reading the law was voted through with 49 votes to zero, and I4 abstentions. The positive mode in 


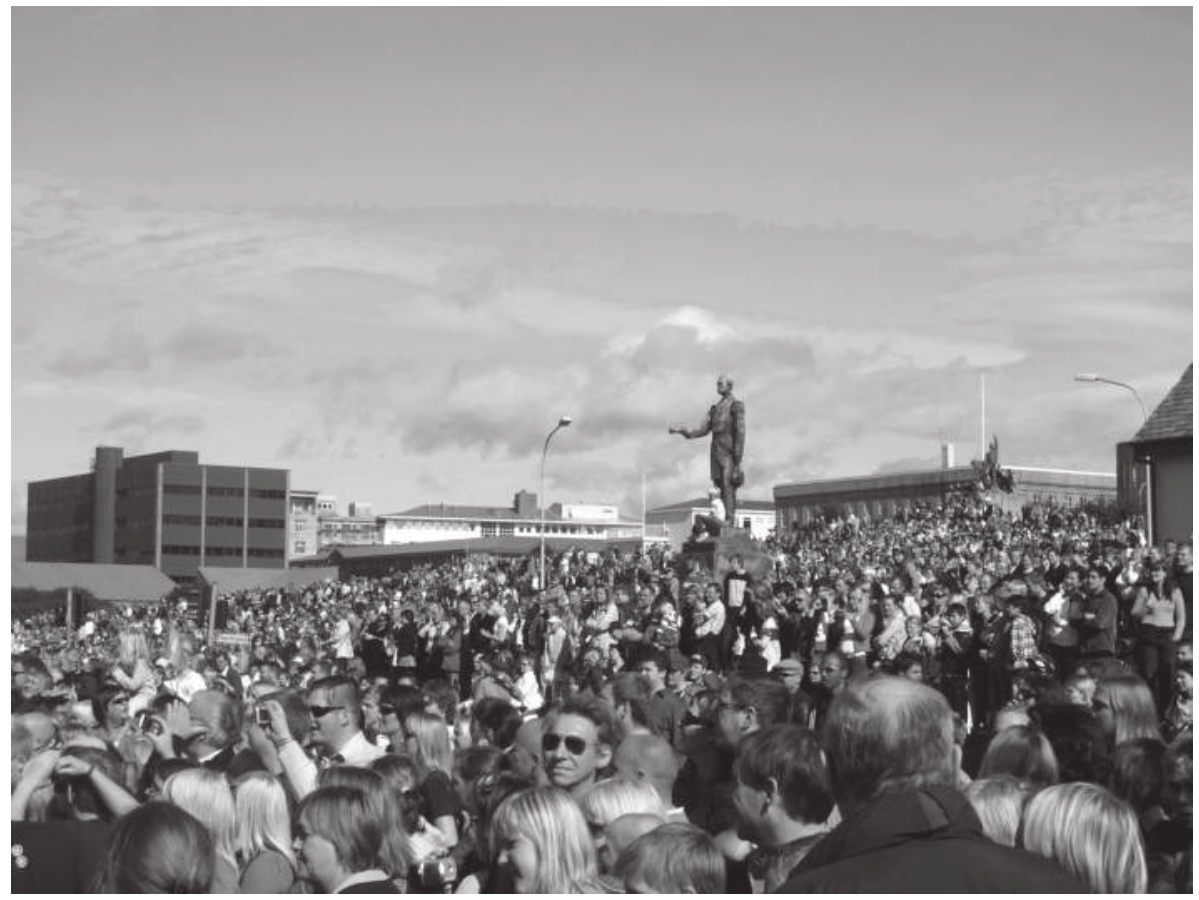

Hinsegin dagar, or Queer Days, in Reykjavík 2007. This event annually attracts tens of thousands of people. Photo: Jens Rydström.

Parliament was perhaps best expressed by Margrét Tryggvadóttir, a representative from the small party "The Movement" (Hreyfingin), as she stood up to vote: "Mrs. Speaker, I say yes with sunshine in my heart. I think Iceland and the world are better today than yesterday." The new marriage law became effective on Christopher Street Day, 27 June 2010.63

Thus, in a few decades, Scandinavia has seen the emergence of exceptional laws for homosexual citizens, granting legal recognition to same-sex couples but defining them as life companionships without children. For those couples who already had children, the legislators were at first at a loss how to grant legal safety to a child without recognising homosexuals as parents, but step by step they were forced by a changing popular opinion and by lesbian, gay, and bisexual activism to accept the combination of a homosexual lifestyle with parenthood. As the factual differences between registered partnership and "real" marriage diminished, the logical next step was to have the same marriage law for both same-sex and different-sex couples.

Three of the Scandinavian countries, Norway, Sweden, and Iceland, have now rewritten their marriage laws in order to allow same-sex couples to marry on the same terms as different-sex couples, and the Church of Sweden has decided to marry same-sex couples. Indications are that legislation in Denmark 
and Finland will eventually go the same way. The laws on registered partnership, once hailed as ground-breaking and revolutionary, have proved to be a parenthesis in history, and the recognition of the rights of same-sex couples seems consolidated in these countries. The price that same-sex couples have to pay for state recognition is that the majority now expects them to act according to the norms of society. Whether this will impoverish queer culture, or the minority culture of those who choose different sexualities, is yet to be seen.

\section{Conclusions}

After witnessing this rapid legal and discursive change, two questions beg for answers. First, how could public opinion change so quickly in Norway and Sweden between 1990 and 2009 that the laws on gender-neutral marriage passed almost without political opposition? (In Iceland there had been no dramatic change. The joint marriage law was carried by the same spirit of national pride and of general consensus as the partnership law fourteen years earlier.) In all Scandinavian countries except Iceland, the laws on registered partnership passed, in their time, with comparatively narrow majorities, a massive media debate, and concerted opposition from Christian, conservative, and rural interests. But in 2005-2008 the gender-neutral marriage laws were prepared and passed in Norway and Sweden with a minimum of political opposition, which in this new situation brought about a defence of the partnership laws. The second question is, how did children come to be part of the image of the gay and lesbian couple? How did the rainbow family appear on the political scene, demanding and achieving state recognition in less than a decade?

In one sense, it was the culmination of the post-Stonewall gay movement's politics of openness in the I99os that paved the way for the gender-neutral marriage, but that is not a sufficient explanation. The gay liberation movement of the I970s had claimed a minority status that strove for minority protection. Anti-discrimination laws, ombudsmen, and laws on registered partnership were results of gay minority politics in Scandinavia. The claims for full marital equality including church marriage, adoption rights, and recognition as parents were there already in the I980s, but were mostly considered far in the future and were not wanted by many. Lesbian feminism and radical criticism of the heterosexual family were important factors in the r970s and I980s. This criticism against marriage faded away, both as a result of a general ideological shift after the end of the Cold War and of a political pragmatism that developed once the Danish law was in place. The question of how the opinion of the majority of the population could swing so dramatically in the I99os requires another answer. This rapid and far-reaching opinion shift can best be explained as a result of gay openness and assimilation, which in the small Scandinavian societies could exert considerable influence on the majority. In a small and highly urbanised society such as 
Iceland, the assimilation of gay culture in everyday society is most evident and is demonstrated at the gigantic Pride parade every year. For in spite of the leather and the whips and bare buttocks, the Icelandic queer days (binsegin dagar), as they are called in Icelandic, are not primarily a manifestation of an exciting and raw subculture, but a mirror of the majority's tolerance. The disciplined queers, waving from the floats, no longer threaten the children of the majority, which joins them in the celebration of their diversity. This is not a bad thing, considering that there was absolutely no sign of a gay or lesbian subculture in Iceland before, just a history of exile and frustration. The opposite pole of Icelandic society would be Finland, which is much bigger and less urbanised. It is the Nordic country that holds the strongest opposition to gay and lesbian emancipation and where rural and Christian conservative interests create a bulwark against diversity. ${ }^{64}$ The core countries of the Scandinavian region, Denmark, Norway, and Sweden, display a more pronounced willingness by the majority to embrace a disciplined and "tamed" queer community - on the majority's terms. As U.S. literary scholar Heather Love has expressed it: "Mainstream society has shown itself perfectly willing to take on particularly attractive, fun, or marketable aspects of the gay lifestyle." 65

However, the commercial explanation, that the market forces have facilitated the mainstreaming of gay and lesbian culture, holds true only to a limited extent in Scandinavia. For various reasons, the "pink dollar" has remained largely illusory in the region, where commercial establishments have had a hard time surviving. With the exception of Copenhagen, where there was a continental tradition of small establishments that catered to the gay community, the Scandinavian gay scene has always been very limited. Severe licensing laws are one reason Scandinavian lesbians and gays have preferred to socialise at home, and that the gay scene has until recently been diminutive in the other Nordic capitals. It wasn't until the I990s that Stockholm, a city with one million inhabitants, managed to have more than one gay disco at a time. As soon as a new disco opened its doors, the old one quickly went bankrupt, since the flickering and faithless gay crowd would flock to the new and abandon the old. There were no gay bars, save the RFSL community centre, and only a handful of restaurants and cafés declared themselves gay friendly. In addition to this, mainstream firms became notorious for not placing ads in gay and lesbian publications. The furniture company IKEA placed ads with gay themes in other countries, but not in its native Sweden. Now the situation has changed and there is indeed more than one gay disco in Stockholm, but the commercial scenes are still remarkably small in Scandinavian cities. One Icelandic activist complained in 2005 that Reykjavík's reputation as a gay Mecca caused U.S. gay men to go there and left them bitterly disappointed behind a cup of coffee in the town's only gay café. ${ }^{66}$

A better explanation for the embracement of a disciplined gay culture is the normalising force of the Scandinavian welfare state. Once let inside into the 
warmth of the People's Home, LGBT people have to obey the house rules. The marginalisation of prostitution and pornography in Scandinavia and the radical feminists' successful campaigns against "the sexualisation of public space" contribute to the disciplining of the sexually deviant. In an interesting move, the Scandinavian s/m scene is now seeking recognition and seems to have had some success. In 2007 , the heterosexual s/m association Sunrice managed to get acceptance for their demands that the RFSU, the Swedish sex reform movement, work for the abolition of sadomasochism as a sickness in the Swedish manual of diseases. The diagnosis was stricken from the manual, and the National Board of Health and Social Affairs vowed to lobby the WHO to do likewise. Ironically, the RFSL, the national association for lesbians, gays, bisexuals, and transgendered, was less benevolent to the demands of SLM, the Scandinavian gay s/m group. ${ }^{67}$

Some of the explanation of the quick deployment of gay marriage in Scandinavia must also be sought in the cuckoo-in-the-nest effect. The readiness of Scandinavian Conservative parties, Centre parties, and Social Democrats to listen to gay and lesbian activists' demands must to a certain extent be explained by the presence of openly gay and lesbian politicians in their ranks. When Wenche Lowzow from the Norwegian Right Party came out as lesbian in 1978, she was ostracised, but when Per Kristian Foss came out in 2000, the political landscape had changed and he could rise to the rank of Minister of Finance. It must be remembered, however, that Foss is a man and Lowzow a woman. The number of openly lesbian politicians in prominent positions is remarkably less than that of gay men.

But why children? It is true that many people have combined a desire for members of their own sex - and sometimes an extravagant love life - with bearing, adopting, and fostering children since time began. But the very idea of modern homosexuality was not connected to having children until recently. It was indeed described as "sterility, barrenness, and death," to quote Gunde Raneskog in the Swedish Riksdag in 1976. And in less than thirty years, Scandinavian welfare societies have redefined this picture and conjured up "life, development, and future" - the same attributes Raneskog awarded the heterosexual couple - to fulfill the lives of their homosexual and bisexual citizens. Why is that?

It is to be noted that the demands for custody of children were on the agenda of the gay and lesbian movements already in the early I980s when the legal regulation of same-sex relationships was first seriously discussed with mainstream politicians. In Iceland, the tradition with strong family ties led to the successful implementation of Samtökin's demand for joint custody over children in a same-sex relationship. In all other countries, however, these demands were consciously sacrificed by the gay activists at the time in order to get the minority legislation of registered partnership. The laws on registered partnership were 
passed in all Scandinavian countries except Finland within a few years between I989 and 1996, despite warnings from their opponents that this was just the first step, and that society had embarked upon a slippery slope that would end with full parental rights for same-sex couples. In the I99os public opinion in all Scandinavian countries was against child custody for same-sex couples. Yet adoption rights and full marital rights were granted ten to fifteen years later. What has to be explained is both why same-sex couples want children and why the welfare state is prepared to recognise their right to have them.

To begin with, it was a way to adapt legislation to reality. The lesbian baby boom, and the development of new assisted fertilisation techniques, gave lesbian couples the upper hand in this struggle for discursive power. Their decision to go public with their family life toward the end of the I99os meant a world of difference to public debate on same-sex couples and children. The transformation of lesbians and gays into child-rearing, law-abiding, good-sex citizens is largely a generational question. As the activists from the r98os have come of age parallel with the publicity of lesbian mothers and the development of assisted fertilisation techniques, child rearing has definitely become an option. Since that generation also has gained considerable political influence, their priorities and demands have an impact on social change in Scandinavia. The younger queer generation, fighting for space in the mainstream gay and lesbian movement, has managed to raise questions within the movement about transgender rights, polyamorous relationships, and political change. But among political decision-makers or within the gay lobby their voices are seldom heard.

The child-rearing same-sex couple, with a place at the day-care centre, schooling problems, and family therapy, is a completely new concept in our societies. Their presence in the different institutions of the welfare state and in the mass media has contributed to a change of opinions that is merely an adaptation to the existing reality.

It is now time to sum up the contents of this book. 



\section{Summary and conclusions}

There are three main focuses of this book: the internal discussions in the gay and lesbian movement, the reception of the ideas in mainstream politics, and the development of state recognition of same-sex couples from acceptance of childless couples to the recognition of rainbow families. Internal discussions had tended to oppose lesbian feminists and gay activists until the Danish law was adopted in 1989. After that, the other Scandinavian gay and lesbian movements stood seemingly united in their demands for registered partnership. The willingness of the political parties to heed the demands of the gay and lesbian movement depended largely on the overall political context, but in some cases it was influenced by energetic and well-directed lobby campaigns. The AIDS epidemic played a crucial part in creating a better understanding of the gay and lesbian movement, but it also gave rise to a perceived need for the disciplining of gay men.

\section{Internal discussions}

Prior to the introduction of the Danish law on registered partnership, on I October 1989, the discussions about gay marriage in the Scandinavian gay and lesbian movements were characterised by many different opinions, but there was a clearly distinguishable difference between men's and women's standpoints. The idea of some sort of legal regulation of stable same-sex relationships had been formulated - mainly by gay men - since the end of the nineteenth century. Lesbian thought, however, was nearly always linked to leftist feminist ideological currents, based on a striving for independence from male dominance and for economic and political self-determination. Most forms of feminist ideology carry a consistent criticism of marriage as an institution, and the idea of marital arrangements for lesbian couples was far from the agenda of most lesbian activists. It may also be true that the economically stronger male couples had more assets to safeguard against their biological kin than women and therefore had a stronger interest in a legal regulation of their relationship.

On the other hand, more lesbians than gay men raised children and would have an interest in creating an economically safe environment for them, as well as securing their right to foster their own children. For this reason, laws on registered partnership that excluded the custody of children were of less interest to 
many women. The question of lesbians as child-raisers was almost always dealt with separately from the question of their legal status as life partners. Since tradition presupposed that fathers took less responsibility for their children, the solution sought for almost always involved the mother.

Per Kleis Bønnelykke worked in Denmark, but he was inspired by an article in a Swiss gay publication when he formulated the first draft proposal of a law on registered partnership in 1972 . This indicates that the idea of a separate registration for homosexuals was not originally Scandinavian but was discussed in different European gay and lesbian movements in the ig6os. The law that was finally adopted does not differ in any significant way from Bønnelykke's original proposal. As noted before, the ideological parties like the liberals or the left socialists - parties that lacked a well-defined class base - were where ideas of gay emancipation could most easily find listeners in the I970s. For this reason, gay activists tended to be of either liberal or socialist political conviction at that time. Bønnelykke was a member of the social-liberal Radical Left Party, for which he worked politically and at various times held office in the local council of his home municipality. In Sweden, gay activist Stig-Åke Petersson was a member of the liberal People's Party and founding father of the Gay Liberals in Sweden.

An important factor to explain both why gay marriage became a priority for the national lesbian and gay movements and why it had any chance to be accepted by mainstream society was the de-radicalisation of the movements. The decision to celebrate Christopher Street Day on June 27, rather than the International Workers' Day on May I, that the Danish movement took in I971, can stand as an early sign of the way they would go. It became at the same time more inclusive of different political views among its members, and more acceptable to majority politicians. The project of a registration for gays and straights and large families, first presented by the socialist parties as part of a plan to abolish traditional marriage, was replaced by a liberal rights discourse, claiming equal rights for same-sex couples.

Toward the end of the I980s it became easier for gay and lesbian politicians to come out of the closet, which sometimes led to a merger of party politics and activism. Jorma Hentilä in Finland was a prominent figure in the socialist People's Alliance and also in the Finnish gay and lesbian movement. In the beginning of the I980 he openly combined gay activism and political work. Hentilä had to concentrate on AIDS prevention and did not work to promote the partnership law, but in the late I980s a generation of Social Democratic politicians and activists, like Torben Lund in Denmark and Kjell Erik Øie in Norway, would take up the work for partnership. In Finland, Hannele Lehtikuusi, active within the Green Alliance, became a front figure for registered partnership and worked in tandem with Rainer Hiltunen from the conservative National Alliance. In Iceland, a growing number of lesbian and gay activists entered main- 
stream politics, and in 2009 the country became first in the world to elect an openly lesbian Prime Minister, Social Democrat Jóhanna Sigurðardóttir. Thus we see a broadening of the spectrum of political convictions among the activists, which went hand in hand with an increase of the number of political parties that would give attention to demands for gay rights.

Scandinavian social democracy was "won for the cause" by initiatives emanating from youth leagues or from gay and lesbian party members in the late I980s, but the conservative parties and agrarian centre parties, more reluctantly, turned to gay and lesbian rights issues only after the turn of the century. The Finnish and, to a lesser degree, the Norwegian agrarian centre parties still host some anti-gay sentiments, whereas the Swedish Centre Party has undergone a complete metamorphosis. This may in part be due to the Centre Party's openly gay vice party leader Andreas Carlgren, but it is also an effect of an ideological reorientation of the party (which enables Carlgren to remain in it), involving a more EU-friendly attitude and a more open attitude concerning immigration. Ironically, the strengthening of the Christian Democratic parties in Norway and Sweden seems to have helped the work for gay rights. Many conservative Christians have left their original parties and have gathered in these parties, thus making it easier to work for gay rights in the other groups.

Besides lesbian feminists, there were also many male activists who were opposed to gay marriage. The Danish Gay Men's Liberation Front (Bøssernes Befrielses Front, BBF) was influential, even if its political strategy leaned more to the esthetical and intellectual. According to Bønnelykke, they were much more pragmatic than the lesbian feminists, and in the I970s he made an effort to integrate them in the political work of The Society of 1948 by offering them posts on the board. The arguments of the BBF were not feminist but were decidedly anti-establishment. As a consequence, they did not actively lobby against gay marriage but regarded it as an utterly insignificant question. Among the women, there were those like the lesbians in Lesbian Front in Sweden, who argued in feminist terms against gay marriage, there were those like Terhi Saarinen in Finland who turned their backs on male-dominated gay politics, and there were those like Anna Mohr and Eva Ahlberg in Sweden, who worked with the men and to a certain extent downplayed feminist ideology. Lesbians who chose to organise in separate organisations lost their influence in mainstream politics, but they argued that they did not have much influence anyway in the male-dominated movement, and they thought it was worth it to be able to work alongside other feminists.

There was an interesting difference between lesbian activists like Else Slange, chair of The Society of 1948/LBL in Denmark, and Kim Friele, chair of The Norwegian Society of 1948 (DNF' 48 ). They were both of the opinion that the partnership law was a discriminatory law, since it did not include custody of children, which they regarded as important for lesbian women. Slange formu- 
lated her opposition to it in more feminist terms about independence during the interview, whereas Friele's argument at the time had more to do with solidarity with those who lack the "ability, will, or possibility" to live in stable monogamous pairs. There was also an important difference in their respective positions of power. Kim Friele was the leader of the Norwegian gay and lesbian movement for over two decades and had a very strong position within Scandinavian gay and lesbian activism, whereas Else Slange was the chair of LBL I989-I994, when the organisation faced a difficult period that ended in economic bankruptcy. Whatever the reason, Slange could not or would not let her views on gay marriage determine the stand of her organisation.

The AIDS epidemic struck Scandinavia at a time when national gay and lesbian organisations had entered a phase of professionalisation and it caused more money to be channelled into the organisations. It also coincided with a period of lesbian separatism in all Scandinavian countries. It is hard to determine in what ways the AIDS epidemic and its consequences affected the lesbian separatism of the time. The plight of gay men and the many deaths generated sympathy, and also worked as an argument for the partnership law, since many widowed men suffered from the lack of public recognition of their relationship, as the families of origin of their deceased lovers claimed the inheritance. But on the other hand, many lesbians felt alienated by the focus on male sexuality. One combined effect of the professionalisation of the gay and lesbian movements and lesbian separatism was that the ideological resistance to gay marriage vanished from the national movements. In Norway, where criticism of gay marriages had been included in the movement's agenda from 1973, it did not happen until later, when the partnership law was introduced in Denmark, and a new generation in Norway began lobbying to get a law on registered partnership.

It would, however, be a mistake to interpret gay and lesbian resistance to gay marriage as solely a question of feminism and of women's and men's different needs and priorities. The criticism was also inspired by solidarity and the quest for alternative lifestyles. Since many lesbians and gay men had had to organise their lives outside the heteronormative community of the welfare state, they had developed a number of strategies to cope with their situation. Life in eternal catachresis, which Judith Butler has described, forced them - or allowed them - to build their own kinship systems. Before the openly gay politics of the I970s, the groups of gay men who formed upper-class coteries in the larger cities included both rich and poor, even if the rich set the rules. Circles of lesbians also began forming in the framework of the emerging club life. Marriages were arranged between women and between men, seeking recognition within the group, often with also a religious blessing, but without the state's recognition. All in all, there was a strong sense of being outsiders and depending on the solidarity and love of the others in the groups. There were of course always couples who would split from the groups and live quiet lives, and they would sometimes 
be accused of anxiously protecting the sanctity of their relationship against the demands of the collective. The idea of seeking public legitimacy from outside - recognition by the state - could be seen as compromising the basic solidarity that was necessary to survive in a hostile environment.

\section{Mainstream politics}

Thus, the idea of gay marriage is old but highly controversial within the gay and lesbian community. The question remains when and why mainstream politicians began listening to gay and lesbian activists. The acceptance of the legitimacy of homosexuality has come gradually, beginning with women and young politicians, and has slowly infiltrated political discourse on the national and local levels in all Scandinavian countries. Certain historical factors have influenced the process and facilitated the integration of gays and lesbians in Scandinavian society.

To begin with, there are strong centre-periphery dynamics within each country and within the Nordic region as a whole. Copenhagen has been described as the gay capital of Scandinavia for generations, and indeed it seems that its proximity to Continental Europe, its large port, and its liberal licensing laws were factors that contributed to the creation of a homosexual subculture long before that happened elsewhere in Scandinavia. The existence of a recognised homosexual centre caused people who sought same-sex pleasures to be drawn to it, and those who remained in the periphery often reacted with disdain at the thought of what was going on in the capital. We have seen that happen when conservative forces in the Faroe Islands, situated in the periphery of the Danish Realm, successfully opposed the introduction of the partnership law and delayed the introduction of a law against discrimination on grounds of sexual orientation. And we have seen that centre-periphery dynamic at work between the other countries when the law spread over Scandinavia. Given the amount of interest and the political situation in each country, it was to be expected that either Denmark or Sweden would be the first country to deal with same-sex relationships. When Denmark broke the ice, it had a decisive influence on the other jurisdictions. The reticence within the gay and lesbian movement vanished when it became apparent that such a solution was politically possible, and the gay movements in Scandinavia began lobbying for the law. The lobbying efforts further broke down resistance within their own ranks, and a seemingly united gay and lesbian movement finally managed to muster a majority in Parliament. The experience from Denmark, where the law did not cause any dramatic change in everyday life, may also have had a reassuring effect on those who were sceptical.

From Denmark, the idea of the law spread across Scandinavia, but sometimes in an unexpected order. It was a surprise to many that Norway introduced the law before Sweden, both because of the explicit opposition to such a 
law within the gay and lesbian movements in Norway, and the strong position of conservative Christian groups in Norwegian politics. However, it can serve as an example of the importance of historical actors. The generational shift in the Norwegian movement guaranteed a concerted lobbying effort, and the polarisation of the debate secured a gay-friendly majority in Parliament, as the opponents to the law increasingly were seen as extremists. The small jurisdictions in Iceland and Greenland introduced the law rapidly and with virtually no political resistance, but the larger and more diverse Finnish society mobilised a stronger resistance to the law. The first attempt to introduce it, in I993, was blocked, and it was not until 200I that it was passed, becoming effective in 2002. The Finnish debate was polarised like the one in Norway, but the urban pro-gay groups underestimated the resistance to gay rights in rural Finland.

The second factor that facilitated the introduction of the partnership laws was a very clear generational shift in politics. The generation of men who came of age in the I950s grew up during the worst homophobic campaign in recent history and were brought up to believe that homosexuality was a dreadful disease that threatened not only the young, but also the very foundations of society. It is fair to assume that only those in this group who had positive experiences of same-sex sexuality, either by themselves engaging in it or by having openly homosexual friends, would find it less problematic to give recognition to that particular lifestyle. In every Scandinavian country the first mainstream politicians who gave support to the laws on registered partnership were either women or young men. There were of course some exceptions, as, for instance, conservative MP Alf Wennerfors or socialist MP Jörn Svensson in Sweden, but the general trend was clear. ${ }^{\mathrm{I}}$

The third factor of importance for the success of the gay rights lobby was a gender shift. The number of women in Scandinavian party politics was small for most of the twentieth century, but in the I990s more women entered the elected assemblies. It may be too soon to assess the impact of this "gender revolution" in politics, but one thing is certain: it has facilitated the introduction and implementation of partnership laws and gender-neutral marriage laws. Today (2009) women make up 47 percent of the Swedish Riksdag, 42 percent of the Finnish Eduskunta, 38 percent of both Denmark's Folketing and Norway's Storting, and 32 percent of the Icelandic Alpingi. The number of women in the Faroese Logting increased from 9 to 22 percent in the 2008 elections, which should increase the chances of introducing pro-gay legislation in the future. ${ }^{2}$

\section{From clowns to clones}

When the laws of registered partnership were introduced in Scandinavia, it was clear to most people that they were just the first step of a development toward full legal recognition of same-sex relationships. Their opponents feared that the 
next step would be granting gays and lesbians custody over children, something they perceived as a threat to the child's best interests, as well as to the family and stable social conditions. Gay and lesbian activists made no secret of what they wanted. The practical issue of child custody and the highly symbolic one of church weddings were highest on their agenda. Of the two, child custody was easiest to comply with. There are many aspects to that issue but, step by step, same-sex couples have been granted the right to stepchild adoption and external adoption, as well as insemination and in vitro fertilisation.

There was a short period in the nineties when the Danish Folketing imposed increased restrictions on gay couples' parenting, but after the 1997 Danish law that barred lesbians from insemination in state clinics (which was abolished in 2007) all amendments to the partnership laws in Scandinavia have been in the direction of making registered partnership more and more like regular marriage.

Stepchild adoption was the reform that came first, and that was also a reform that was given priority by the gay and lesbian movements. It was an efficient argument to point to the situation of children already living with two parents of the same sex, and there were concrete legal issues influencing the legal situation of children in such relations. If a person was opposed to stepchild adoption, they had to argue that it was worse to live with two mothers than to live with a single mother, and this was no longer a valid argument in the public debate. The possibility for registered partners to adopt their partner's children was granted, first in Denmark (1999) and last in Finland (2009). This reform was generally perceived as a reasonable adjustment, giving more legal security to children raised in same-sex relationships, but external adoption was discussed in completely different terms. Arguments against such a reform were, among others, that gay and lesbian couples for selfish reasons wanted to adopt children without regard to the fact that those children would suffer the double stigma of being adopted and having an unusual family situation. There was also opposition from various adoption agencies, fearing that a law permitting gay and lesbian couples to apply for adoption would jeopardise the chances for other childless couples to adopt. There was, however, enough scientific evidence to demonstrate that the situation for children raised in same-sex relations differed in no significant way from that of children from "normal" homes. Moreover, the gay and lesbian lobby now enjoyed considerable support among centrally placed politicians from many different parties in all Scandinavian countries.

Sweden was the first country in Scandinavia to grant full adoption rights to same-sex couples. The reform followed a Government commission's report that found no valid reasons for preventing lesbians and gays from adopting children. It deemed it necessary, however, to investigate further the matter in order to solve the legal problems concerning the custody of children born with the help of assisted reproduction techniques. Some voices were raised saying that the adoption question typically was solved first, since it was an issue that con- 
cerned both women and men. Insemination and in vitro fertilisation were issues that concerned primarily women, it was said, and thus were given less priority. In hindsight, it seems to be an unfair accusation. The legal problems in connection with parenthood when children are born without a social father are quite different from those concerning adoption. The Scandinavian welfare states had designed their family laws to ensure that every child should have a father. These laws were enacted when it was a political necessity to make fathers take responsibility for their children.

The general rule that the husband of a woman who gives birth is automatically considered to be the father of the child until this presumption is challenged, is a rule which gives peace to many heterosexual families. To extend that rule to a female registered partner of a biological mother, however, went against the feelings of many policy-makers. This question is related to the one about whether a sperm donor should be able to remain anonymous to the child or not, i.e. whether the identity of a biological father should be regarded as so important to the child at some point that the identity of the father be disclosed. The Scandinavian countries have chosen different paths here. After long discussions since the I980s, the Swedish Law on genetic integrity (2006:35I) ruled that the identity of the sperm donor must be kept on record, and that the child conceived through sperm donation has the right to know who her or his biological father is at the age of eighteen. ${ }^{3}$ Denmark has the opposite policy. In Denmark all sperm donors to state-run clinics retain anonymity. Finland and Norway have eventually followed the Swedish way, with the result that there is a lack of sperm donors in all those countries, and women keep going to Denmark to become inseminated. ${ }^{4}$

Possibilities of cloning human beings offer new perspectives. When will the first infant be born as a monozygotic twin of an already living person? The ethical complications of such a development may seem staggering. On the other hand, the early discussions in the I980s concerning in-vitro fertilisation conjured up science-fiction-like visions of "man playing God" and anticipated dreadful scenarios, and now it is a fully accepted medico-social practice. It is to be expected that human cloning will be offered in the not-so-distant future, and that the ethical problems surrounding it can be dealt with. Who could be more interested in that kind of service than gay men? Since lesbian women have made themselves fully independent of men with the development of assisted reproductive technology and the supply of sperm from anonymous donors, gay men are at a loss where to get children. Since only a small minority can actually adopt children, and only the most well-to-do can employ a surrogate mother which might backfire if she decided to claim her baby - perhaps cloning would be cheaper and more reliable. The prospect of having one's identical twin growing up with a thirty-to-forty-year delay seems frightening to most, but it may become something people get used to. 
We don't know much about possible ethical discussions in the future, or the kinds of checks and balances the legislators may want to impose on cloning, but we do know that it could become a prosperous business, since there would certainly be many gay men who would willingly go through hardship to get a child of their own. And we know that humans are a remarkably adaptable species.

\section{The lessons of history}

What lessons can we get from the history of registered partnership and gay marriage? Who was right? The lesbian feminists warning of a strengthening of patriarchy, or the middle-class gay men who claimed that the legal regulation of same-sex couples would lead to a more just and democratic society? As always, the answer depends on what perspective one applies.

From a white middle-class perspective, in a broad sense, the laws on registered partnership have without doubt meant more justice for gay and lesbian couples and improvement of the living conditions for many individuals. State recognition of same-sex couples on almost the same terms as different-sex couples was the beginning of a development that eventually led to their equality before the law in Norway, Iceland and Sweden. Moreover, state recognition of a homosexual lifestyle has made it easer for lesbians and gay men in Scandinavia to get recognition from their families, in their workplaces, and from their neighbours. The visibility of lesbians and gays in society has increased tremendously in the last twenty-five years, which has lessened discrimination and persecution. The price for increased visibility is greater exposure to hate crimes, but most people seem to agree that the solution to that problem would not be to become less open. State recognition of rainbow families, finally, has improved the conditions for children being raised by same-sex couples. When the existence and rights of children with parents of the same sex become acknowledged and talked about, the risk of harassment in schools and day-care centres diminishes. The formalities around parenthood mean less to children, but many teachers and staff seem to need a framework for new family constellations. These positive changes of course do not depend on the laws on registered partnership per se. Likewise, many of the improvements in the living conditions of gay and lesbian citizens might have come about without state regulation of same-sex couples. But the process of recognising same-sex couples in the welfare state has had the important effect of revealing to the heterosexual majority the existence of same-sex desire on all levels and in all geographical regions in Scandinavia. The price for this is an adjustment of lesbian, gay, and bisexual lifestyles to the norms of matrimony.

From a queer and lesbian feminist perspective, the fear that the family - the cornerstone of patriarchal society - would be strengthened has proved right, at least within a small minority of lesbians and gay men. Ideas of fidelity and life- 
long commitment have apparently become stronger than they were before, and the quest for alternative lifestyles, extended households, and multi-partner relationships is less prevalent now in political discourse. Same-sex couples imitate many of the symbols of heterosexual patriarchal matrimony, as they stride up the aisle in long gowns and veils or tailcoats. But does the strengthening of the family in this sense necessarily strengthen patriarchy? The core idea of the different theories of patriarchy in the I970s was that the exploitation of women's unpaid work by men weakened women as a group and perpetuated their submission to men. The family was seen as the centre of gender-based exploitation, allowing individual men and men as a group firmly to dominate and discipline women. Patriarchal structures prevail in Scandinavia. Women are paid less than men and carry the bulk of the child-raising responsibility. But the emancipation of lesbians and gays has taken place parallel to an increase of women's power in Scandinavian - and global - society. The presence of women in elected bodies has increased, and the visibility of women in the public sphere has grown. Paradoxically, the strengthening of family values comes at the same time as an expansion of women's role in politics and an incorporation of LGBT lifestyles in the welfare state. And the same-sex couple cannot be said to contain the same potential for gender exploitation as a heterosexual family. It may be a place of dominance and violence, but it does not build up patriarchal power. The imitation of heterosexual marriage and its norms, on the other hand, has other effects that increase the obedient majority's power over the disobeying few.

Strengthening of family values for same-sex couples has entailed a loss of variety in alternative lifestyles and a further marginalisation of "bad" sex. State recognition of the LGBT community has served to discipline a group which, before, moved beyond the boundaries of "decency." Sexual practices that Gayle Rubin placed on the lower half of the sex hierarchy scale ("lesbians in the bar, promiscuous gay men at the baths or in the park, transvestites, transsexuals, fetishists, sadomasochists, for money, cross-generational") are still, or even more, excluded from "decent" society. ${ }^{5}$ Gay and lesbian couples, with or without children, have obtained recognition, which has improved their quality of life, but the price is that they have been barred from the more contested, some would say more interesting, domain of "bad" sex. Now that lesbians and gays have obtained full recognition, expressed both practically and symbolically through the laws on registered partnership and new marriage legislation, they are expected to observe the same rules that the majority is expected to follow.

This, however, need not mean that they "imitate" heterosexuality. For what is there to imitate? Heterosexuals are expected to marry, get children, and live happily ever after. But how many do that in reality? The difference is that now the same fantasy of matrimonial happiness applies to both same-sex and different-sex couples. 
Parallel to the mainstreaming of LGBT culture, a counter-movement has grown and become stronger. The Gay Pride celebration in Stockholm has been challenged by Gay Shame events. Young non-heterosexuals formulate new and unprecedented definitions of what sexuality and gender are, and with a growing awareness of the limitations of the majority's rules, many queer people create their own ways of living. Foucault's claim that where there is power, there is also resistance, is corroborated by events in Scandinavia. ${ }^{6}$ The same inventiveness that characterised the homophiles who were barred from social recognition is now a trait of young generations of non-heterosexuals, who reserve the right to define themselves differently.

The "barren clowns" who opened this book have now become folded into life, by being conceptually included in the group of fertile child-rearing citizens. But behind these obedient, well-defined practisers of "good sex" lurks an army of disobedient lovers: the bisexuals, the crips, the polyamorous, the sadomasochists, the transgendered, who are living and loving without asking for permission and without demanding official recognition, just the absence of harassment and persecution. 



\section{Notes}

\section{Notes preface}

I Hawaii Supreme Court, Baehr v. Lewin, 852 P. 2 d 44, clarified, 852. For a similar discussion, see Wintemute 200I.

2 A word on terminology. "The Nordic countries" (or Norden in Danish, Norwegian, and Swedish, Nordurlandid in Icelandic, Nordurlond in Faroese, Pohjoismaat in Finnish, and $\mathrm{Nu}$ nat Avannarliit in Greenlandic) is the most commonly used expression among Scandinavians to designate the members of the Nordic Council, i.e. the five independent countries Denmark, Finland, Iceland, Norway, and Sweden, and three autonomous areas, the Faroe Islands and Greenland in the North Atlantic (which depend on Denmark, but which have a rather far-reaching autonomy) and Alland in the Baltic Sea (which belongs to Finland and has a more restricted autonomy). In its narrower geographical meaning "Scandinavia" is often held to include only the countries on and immediately south of the Scandinavian Peninsula: Denmark, Norway, and Sweden. Here we will, however, use Scandinavia, a concept more familiar to non-Scandinavians, to cover the whole area of the countries that are members of the Nordic Council.

In this book, I have kept the spelling of names and some institutions in their original languages. Thus, the parliament in Denmark is called the Folketing, in the Faroe Islands the Logting, in Finland the Eduskunta (and also Riksdag, since Finland is bilingual), in Greenland the Inatsisartut, or Landsting, in Iceland the Alpingi, in Norway the Storting, and in Sweden the Riksdag. For stylistic reasons I alternate between designating them as "Parliament" or using their original name. In the text, but not in the bibliography, I have also spelled Icelandic names with Icelandic letters. Thus "P" in Porvaldur instead of "Th" and "ð” in Guðrún instead of "d". For an overview of Scandinavian history, see Nordstrom 2000.

\section{Notes introduction}

I Lag om registrerat partnerskap. Leaflet from the Swedish Justice Department 1995, in the author's possession.

2 Cf. Bech 1992.

3 In Finland only stepchild adoption is possible (December 20Io).

4 The criticism of marriage as a norm which exists today in the various Scandinavian countries has a rather limited impact and does not advocate the abolishment of the laws on registered partnership. Before the elections in 2006, the Swedish party Feminist Initiative (Feministiskt initiativ) proposed the abolishment of marriage as such and its replacement 
by an act of registration, but this proposal had only limited support in the general population. "Ett utmärkt initiativ," Expressen, 15 September 2005.

5 Rubin 1993 (I984), I4.

6 Warner 1999; Butler 1993; Butler 2000; Butler 2002; Duggan 2004b; Duggan and Kim 2005; Love 2007, 152-63.

7 "California voters ban gay marriage," The New York Times, 5 November 2008.

8 Butler 2002, I4.

9 Lévi-Strauss 1949; Rubin 1975.

Io Butler 2000, 78 .

II Chenier 2008. Elise Chenier has later told me that the term "freak wedding" must be understood as a theoretical term. These were real weddings, even if they were not recognised by the state. Private conversation, I5 April 2010.

I2 Foucault I99I, 8, 75. Some observers would strongly disagree that this characterisation applies to the whole of Scandinavia and argue that it may be true for Sweden, but certainly not for Denmark. Instead, they would emphasise the Danish frisind as a factor that makes Danish society less controlled than the Swedish. See for example Bech 1992. My counter argument to that is that the structures of the Scandinavian welfare state create a ground for subtle control mechanisms in all Nordic countries.

I3 Kettunen 1997.

I4 Foucault 1975.

I5 Duggan 2004a; Manalansan 2005; Harris 2006.

I6 Fraser 1997; Fraser and Honneth 2001; Honneth 2003; Fraser 2008.

I7 Rainbow family is a concept which is used in many different contexts, and the rainbow symbol is used in a variety of contexts: the peace movement, ecologism, interracial integration, LGBTQ activism, to name the most common ones. In this book, it stands for family constellations where at least one parent self-identifies as a non-heterosexual. Cf. Regnbågsfamiljers ställning 2009; Zetterqvist Nelson 2007.

I8 Edelman 2004; Puar 2007, 34-36.

I9 "Il s'agit d'ouvrir à l'homosexualité le couple mais non la famille." Borrillo and Fassin I999, 2.

20 Mesner and Wolfgruber 2006; Morgan 2006.

2I For a more thorough discussion of this, see Rydström 2008.

22 "Det heterosexuella har livet, utvecklingen och framtiden inbyggda i sig självt. Det homosexuella har steriliteten, ofruktsamheten och döden i sig." Riksdagen 1977-78. Gunde Raneskog. Proceedings 1977/78:93, 52 .

23 Halberstam 2005, $152-53$.

24 Edelman 2004, I9-2I.

25 The youth organisations of the various national LGBT organisations in Scandinavia and the Association of Nordic LGBT Students (ANSO) have developed a radical critique of the dominant ideals of stereotypical gender expressions as well as traditional forms of cohabiting and coupling. For a number of years, Gay Shame in Stockholm attracted participants critical of the commercialised mainstream events connected with the Gay Pride festival. "Gör som shame - tänk om!” Sylvester 2 August 2002, at http://www.sylvester.se/ content/column.asp?itemid=II25, viewed 2 February 2010.

26 In the Swedish coalition Government of the Moderates, Liberals, Centre Party, and Christian Democrats that came to power in 2006, there was one openly gay minister, Minister of Environment Andreas Carlgren (Agrarian Centre Party), and one openly bisexual minister, Minister of Integration Tobias Billström (Moderates). Maciej Zaremba, "Ska 
läkaren bli bödel?" Dagens Nyheter, II May 2008; Tobias Billström, "Zaremba utelämnar medvetet fakta," Dagens Nyheter, I5 May 2008; Harry Ascher, "Vård är en mänsklig rättighet" Dagens Nyheter, 20 May 2005; Maciej Zaremba, "Från godhet till godtycke," Dagens Nyheter, 29 May 2008; Tobias Billström, “Ställ tydligare krav på våra invandrare," Dagens Nyheter, 26 August 2008. Veer 2006; Rydgren and Widfeldt 2004.

27 Hoad 2006; Krouse I996; Dunton and Palmberg 1996; Rydström 2005.

28 Halperin 1990; Sedgwick 1990, 44-48; Cf. Halperin 2002, IO-I3.

29 Foucault 1971; Foucault 1976. See also Anthony Giddens' criticism of Foucault, on other grounds, for misinterpreting the modernisation of sexuality: Giddens I992, I8-34.

30 When I use newspaper clippings from one of these collections, I refer to the printed newspaper, which is more easily obtainable from the National Library of each country. One side-effect of using clippings is that I many times refer to reports published in a small provincial newspaper, rather than in the leading newspapers of each country. Because of linguistic shortcomings, I was helped in Finland and Iceland to find my way through the archives by Anna Heino and Hrafnkell Tjörvi Stefánsson.

3I Haraway 1988; Rydström 1996.

32 Weeks 2007 , I36.

33 Hansen and Jørgensen 1993, 91.

34 "Rapport fra partnerskapsgruppas arbeid 1988-I993." Unpublished report in the Archives of DNF' 48 , RAN; Øie 1995. The conflicts between Friele and Øie concerned a lot more than gay marriage. The younger generation questioned Friele's leadership on many levels, but for this study, it is mainly the conflicting opinions on gay marriage that are of interest.

35 Ytterberg 200I; Halvorsen and Teigene 2004; Friele 1990, 2000; Westerholm 2000.

36 Størksen 2000. Cf. Sabatier and Jenkins-Smith 1993; Stone 2002 (1988).

37 Bech I992, I44; Cf. Bech I997, 194-217; Rosen I994.

38 Søland $1998,66$.

39 Lützen 1998.

40 Halvorsen 1998.

4I "Annerledesheten som loven regulerer, gjøres samtidig synlig, og det kan like gjerne lede til at det settes spørsmålstegn ved heteroseksualiteten som en normerende størrelse." Markussen 2002, 250.

42 Halvorsen I998, 22I.

43 Bech 1992, I36, I44.

44 Søland 1998, 65; Lützen 1998, 234.

45 Adeniji 2008.

46 Einarsdóttir 2008, 2. I thank Anna Einarsdóttir for giving me access to her unpublished thesis.

47 Bech 1992, I47, n. I3.

48 Some of the effects of the Danish frisind, which indeed distinguish it from the other Nordic countries, are more liberal policies on alcohol, drugs and sex. For an overview of the history of Scandinavian welfare states, see Christiansen and Petersen 2oor; Christiansen et al. 2006 (eds.); Åmark 2005.

49 Sullivan 2004, I55, quoted from Ashbee 2005, I6r.

50 Kurtz 2004; Eskridge et al. 2004.

5I Representative Mike Pence of Indiana, Congressional Record, Marriage Protection Amendment - House of Representatives, September 3oth, Io8th Congress, H79I2, (2004), 
thomas.loc.gov, quoted from Ashbee 2005, I70. Another author making the conservative case for gay marriage is Rauch 2004 .

52 Warner 1999. Cf. Goffman I963.

53 Duggan 2002; Duggan 2004a; Duggan 2004b; Duggan and Kim 2005. Discussions of homonormativity have been scarce in Scandinavia, an exception being Bertilsdotter Rosquist 2009.

54 Robinson 2005.

55 Chauncey 2004.

56 Like Henning Bech, they use the concept of frisind to explain why Denmark was first to introduce the law on registered partnership. Eskridge and Spedale 2006, 58-6r.

57 Eskridge and Spedale 2006, I29.

58 Merin 2002.

59 Jordan 2005, 95 .

6o Badgett 2001; Badgett 2009, I49.

6I Badgett 2009, I82-99.

62 Wintemute and Andenæs (eds.) 200I; Cooper 200I; Halley 200 .

63 Waaldijk 200I, 440; idem 2004.

64 Norway decriminalised homosexuality in 1972 without imposing a higher age of consent for same-sex sexual relationship. It has been argued, however, that the Norwegian Criminal Code of 1902 (in force 1905) contained a de facto decriminalisation, combined with a higher age of consent, since it stated that "unnatural fornication" between men should only be prosecuted "when public interest so demands" (naar det paakreves af almene bensyn). This meant that homosexual acts were only prosecuted when the men were under 20 and/or violence was involved. For a more detailed account of these legal changes, see Halsos 2007. Something which recently challenged Waaldijk's first law was that Greenland first introduced registered partnership, in 1996, and long after that, in 2010, adopted a law against discrimination on grounds of sexual orientation.

65 Korpi 2000; Veggeland 2007.

66 Chambon 2005.

67 Borrillo and Lascoumes 2002; Festy 2001.

68 Fassin 2005.

69 Schimmel and Heun 2000.

70 Bosinski et al. 2001; Dittberner 2004; Gerhard 2009.

7I Mielchen 200I.

72 Banens and Mendès-Leite 2008.

73 Oral presentation by Henning Bech at the conference Same-sex couples, same-sex partnerships and homosexual marriages: A focus on cross-national differentials, Stockholm University, 25-26 September 2003 .

74 Andersson et al. 2006; Rothblum et al. 2008; Carpenter and Gates 2008; Black et al. 2000. "steriliteten, ofruktsamheten och döden" Riksdagen 1977-78. Gunde Raneskog. Proceedings $1977 / 78: 93,52$.

75 Weston I991; Giddens I992; Weeks et al. 200I; Weeks 2007.

76 Stacey and Biblarz 200r; Hicks 2005. Cf. Zetterqvist Nelson 2007, 17-22.

77 Ryan-Flood 2005, 2009. The requirement that the identity of the sperm donor be known to the child in Finland, Norway, and Sweden has resulted in a shortage of sperm. Assisted reproduction 2006. 


\section{Notes chapter I}

I “riktigt bröllop ... Men det var väl många som rynkade på näsan åt det och tyckte att det där var ju lite utöver det vanliga. Det var ju ganska djärvt på den tiden ... Det gick ju till så at dom inför oss som vittnen lovade varandra evig trohet och växlade ringar och sedan åt vi middag." Sven, interviewed by Fredrik Silverstolpe in 1984. Quoted from Silverstolpe et al. 1999, 512-513. For an account of Jerry's Ladies Clubs, see Bengtson 1998.

2 Kristiansen 2008; Lindholm and Nilsson 2002. For other examples of lesbian weddings, see Chenier 2008.

3 Bradley 1996, I3.

4 Melby et al. 2006, 55-90; Bradley 1996.

5 Melby et al. 2006, 369-72. Danielsen and Lødrup 1988.

6 The generational rebellion in the I96os and I970s was truly global. One needed only to own a radio to listen to the new music, and fashion and hairstyle became universal. Hobsbawm 1994, 295-302; Lennerhed 1994; Östberg 2002; Ljunggren 2009.

7 Egteskabs indgåelse 1964; "anerkendt af overøvrigheden ... registreres hos overøvrigheden" Folketingstidende 1968-69. Tillæg A, col. 965. Melby et al. 2006, 370-71; Christensen and Kristensen 1972. The marriage commission of 1957 did not produce any law reform. Instead, a new marriage law commission was appointed in 1969. Melby et al. 2006; Bradley I996.

8 SOU I972:4I.

9 RFSL PM ${ }_{13}$ October 1972. "Familjerätt.” RFSL 1970-. RFSL. Interview Petersson.

Io "sexuella avvikare" In Swedish, the expression "sexual deviants" did not carry the same strong negative connotations as it does in English. Riksdagen 1973. Mot. 1973:I793, p. 2; Bet. 1973:LU20, p. II6.

II Ibid.

I2 Svensson I975; Johansson (ed.) I996.

I3 The events on 27-30 June 1969, when a routine police raid on a gay bar in Greenwich Village resulted in three days of riots on lower Manhattan, have obtained iconic status in lesbian and gay historiography. Later research suggests that they were one of several events - albeit the most medialised - of lesbian and gay resistance in the I96os. For an account of the San Francisco riots in 1966, see Stryker 2005. The Norwegian movement broke with the older politics of discretion well before the Stonewall events. Its new chair, Karin-Christine (Kim) Friele, had a political agenda, which resembled I97os gay and lesbian politics, when she took office in 1966. According to Norwegian historian Hans W. Kristiansen, the importance of the break with the old has been exaggerated, but he concedes that there was a definite change of tactics, from a politics of discretion to a more confrontational policy. Kristiansen 2008, 210. Cf. Friele I975.

I4 Interview Bønnelykke. PAN-bladet no. 4 (I97I). It should be noted that the Danish translation of Gay Liberation Front, Bøssernes Befrielses Front, literally means Gay Men's Liberation Front and only men were organised. Interview Rosen.

I5 The homophile movements is a term generally attributed to the organisations for homosexual men and women between 1950 and 1970, a period when they wanted to claim the word "homophile" as less sexual than homosexual. The lesbian and gay movements in general stopped using the word in the I970s, with the exception of Norway, where it is still used. Interview Bønnelykke; Axgil and Fogedgaard I985; Petersson 2000; Kristiansen 2008. I6 Sodomy between men was illegal in Norway until 1972, but already in 1905 the Norwegian criminal code was worded so that prosecution would take place only "when public 
interest demands," which according to Martin Halsos amounted to a de-facto decriminalisation of same-sex relations between adults. After 1905, the Norwegian ban on male samesex sexuality was generally only imposed when under-age boys were involved. Halsos 200I, IO4; idem 2007, 94-96; Jordåen 2003; Friele 1985. Cf. Kristiansen 2008, 76-8I.

I7 Rydström and Mustola (eds.) 2007, 21; Rosen 2007, 84-86; Rydström 2007b, 206-7; Petersson 2000, 3I-32; Thorvaldsdóttir 2007, I36-37; Mustola 2007, 24I-42.

I8 Referat av generalforsamling I973, "Generalforsamling 1953-I982," Aa ooor, Det Norske Forbundet av 1948 (DNF' 48). Privatarkiv I216. Riksarkivet, Oslo (RAN); "Referat fra vår nordiske informasjonskonferanse på Leangkollen I9-20 mai 73” Leangkollen. Friele's Archives.

I9 "homofili i hovudsak er eit seksuelt avvik med røter i samfunnsmessige og sosiale tilhøve ... det ikkje er kommunistar si oppgåve at fremje homofili eller å propagandere at homofili er 'ynskjeleg'." Quoted from Bergh and Jensen 1984, I6.

20 "vi vil som marxist-leninister, ut fra marxismen-leninismen og århundres erfaring, ikke anse homofili som en ønskelig tilstand." Quoted from Bergh and Jensen 1984, I6. The wording in Friele 2004 is slightly different but has the same meaning.

2 I "usignert ml-stoff” Friele 2004.

22 Bergh and Jensen I984.

23 Interview Pareli.

24 Interview Pareli. My description of the events is based on a combination of the accounts in FHO activists' Steinar Bergh and Finn Jensen's 1984 article "Sekteristisk eller progressiv homsekamp?" from I984 and Kim Friele's article "Historien om et 'Fråsegn om homofili" from 2004. A telephone interview with Leif Pareli and material from the archives of DNF ' 48 have also been used. Ah Eksklusjonssaken. Det Norske Forbundet av 1948. Privatarkiv I216. Riksarkivet. Oslo.

25 Friele 2000; Norwegian Law 5 June 1970, No. 34, added § 135a to the Penal Code, with a prohibition of publicly insulting or discriminating against a person on grounds of her or his sexual orientation.

26 "Seppo ja Jussi ovat seksuaalipakolaisia," Hymy 1980; "Homoseksuaalit protestoivat Suomea vastaan," Hämeen Sanomat 23 August I980; "Sexualpolitiska flyktingar från Finland höll demonstration i Stockholm," Österbottningen 23 August I980.

27 In 1967, the first Finnish gay group was founded, "The Group of the Second Ray" (Toisen säteen ryhmä). Politically radical, it was inspired by the hippie movement, and its manifesto rejected identity politics, arguing against the separation of people into sexual categories. It was tactically changed to Psyche, a new organisation, in I968. Mustola 2007, 237; "Sateenkari Suomi / Regnbågsfinland” Website: http://www.vanda.fi/i_perusdokumentti. asp?path=109;3751;7426;62495;6710;72448;72482 (viewed I2 March 2008); Interview Saarinen.

28 Icelanders in general are proud of their language, which is considered the oldest and best preserved Nordic language, and strict rules apply to the use of language and the introduction of new words. In this case, however, "linguistic purity" was used as a means to further oppress an already marginalised minority. Letter 24 April 1978 from Samtökin '78 to Íslensk Málnefnd. Letter 20 May 1978 from Íslensk Málnefnd to Samtökin '78. Askja 3. Samtökin '78 Archives. Borgarskjalasafn Reykjavíkur (BR).

29 Ingibjörg Sólrun Gísladóttir said during the interview that when she was young some of her friends were not admitted to discotheques because they were known to be homosexual. When she studied in Denmark from I979 to I98I she met many homosexual Icelanders 
in Copenhagen. They longed to go back to Iceland, but they couldn't, she said. Interview Sólrun Gísladóttir.

30 Only seldom did new groups coexist with groups of the older order. This happened in Göteborg, in Sweden, where the new and the old activists could not coexist in the same organisation, and where RFSL for a long time had two chapters. Chapter One (Avdelning I) organised the older generation and Chapter Two (Avdelning 2) gathered the young radicals. Petersson 2000. During the I970s in Finland, the "homophile" group Psyche as a rule organised the older generation, and SETA the young radicals. Petersson 2000; Rydström and Mustola (eds.) 2007; Magnusson (ed.) 2000.

3I Sundberg 2002; Ross and Landström 1999; Interviews Eddudóttir, Saarinen, Slange; Magnusson (ed.) 2000.

32 For instance, when lesbian feminists threw sour herring into the cars of sex buyers, or when they interrupted the "lesbian" live show at a Stockholm night club, angry gay men attacked them in the movement's internal press. Sundberg 2002; Ross and Landström I999; Rydström 2007c; Hallgren 2008.

33 Vallgårda 2003, 247.

34 Svéd 2000, 230. Cf. Friele 1990, 294; Lunden 1997, 22. The then head of the Swedish National HIV-counselling service, George Svéd, has described how difficult that decision was. "Will it not only stigmatize homosexuals and bisexuals further and will it not confirm the view that gay men spread AIDS instead of being the victims of AIDS?" he wrote in an article from 2000. ("Kommer detta inte bara att stigmatisera homo- och bisexuella ytterligare och tas till intäkt för att det är bögarna som sprider aids i stället för att det är bögarna som drabbas?"

35 The RFSL claimed that no case had been reported in which infection had been transmitted solely via oral sex. Moreover, it argued that since there was no cure for or treatment against AIDS, and safer sex should be practiced regardless of one's HIV status, there was no need for testing from an individual point of view. On the contrary, the risk of discrimination of HIV positive persons was such - especially in view of the coercive legislation enacted by a panic-stricken society - that testing was counter-productive. Svéd 2000; Westerholm 2000; Interview Westerholm.

36 "en overordentlig positiv særbehandling" Juul-Jensen 1996, г3.

37 Vallgårda 2003, 252-58; idem 2004; Lunden 1997.

38 Lunden 1997, I3-15, 21, 26-27.

39 "Vi hadde fått ett rykte att være - motsatt dere i Sverige - veldig ansvarskjennende. Derfor tror jeg ikke heller de stengte saunaklubbene hos oss.” Interview Øie and Sørensen. 40 "Medicinalstyrelsen gav inga som helst råd eller så. Inga som helst föreskrifter ... Vi gav rådgivning. Där var läkare och psykolog . . V Vi kom överens med Folkhälsoinstitutet att de skulle behandla de tester som vi ger. Och vi kom överens om anonymitet. Det var en viktig överenskommelse." Interview Hentilä.

4I Mustola 2007, 24I.

42 Statistics Iceland, www.hagstofa.is. "AIDS - Hvers vegna nú?" Morgunbladid, $20 \mathrm{Au}-$ gust I983; "Eyðni besta orðið," Morgunblaðið, 8 November 1983; "Alnæmi: hættan mikil hér," Morgunbladid, I3 November 1983. Cf. Jónsdóttir 1994; Jónsdóttir and Haraldsdóttir 1998; Christensen 1988.

43 Interview Jógvansdóttir; Interview Moti.

44 Interview Semionsen. "Uagut aamma inuuvugut ... / Vi er også mennesker ..." Atuagagdliutit/Gronlandsposten (AG), I March I994; Aamma illit inuuneraat 2004, 40-44. 
45 Riksdagen I975. Mot. I975:I44 (vpk), 1975:I286 (fp), 1975:1249 (vpk); Bet. I975:LU8, 1975/76:SoUi9; Mot. 1976/77:139 (vpk), 1976/77:725 (s), 1976/77:1099 (fp); Bet. 1976/77:SoU37; "sammanställa och redovisa tillgänglig vetenskaplig dokumentation om homosexualitet ... föreslå åtgärder som behövs för att undanröja kvarvarande diskriminering av homosexuella." SOU I984:63, 30.

46 SOU I984:63, I3-I7; Andreasson 2000, 51-52.

47 Riksdagen I986-87. Prop. 1986/87:I24; Bet. 1986/87:SoU31; Lag (1973:65I) om ogifta samboendes gemensamma hem; Lag (I987:232) om sambors gemensamma hem; Lag (I987:813) om homosexuella sambor.

48 The four gay-friendly parties in the Danish Parliament were the left-of-centre liberal Radical Left Party (Radikale Venstre RV), the Socialist People's Party (Socialistisk Folkeparti, SF), the Social Democratic Party (Socialdemokraterne), and the Left Socialist Party (Venstresocialisterne, VS).

49 Interview Hansen.

50 "til belysning af homoseksuelles situation i samfundet ... herunder forslag til bestemmelser for faste samlivsforhold." Folketingstidende 1983-84. Tillæg C, col. 5I4.

5I Folketingstidende 1985-86. Tillæg C, col. 1029; Folketingstidende 1986-87. Tillæg C, col. 587 .

52 Homoseksuelles vilkair 1988, I22-I28. Poul Dam added that nothing suggested that any other Nordic country was interested in adopting a law on registered partnership. A Danish decision in that direction would alienate Denmark from the legal system of its neighbouring countries (p. I28).

53 Skýrsla 1994, 42-43, 49-52, 65-68.

54 "To personer af samme køn kan lade deres partnerskab registrere." Folketingstidende 1987-88 (I. samling). Tillæg A, col. 354r; Folketingstidende 2I January 1988. FF col. 5285; Folketingstidende 16 March 1988, FF col. 8355.

55 The Government Poul Schlüter III, the so-called KVR Government, was in power from 3 June 1988 to I8 December 1990. Folketingets årbog I988, I990.

56 Interview Lund.

57 "man skal jo opføre sig ordentligt på sådant et sted, så man kan jo ikke sidde og huje og råbe hurra og sådan noget, hvad? ... Og så havde vi aftalt med alle dem der var der, at når forslaget var blevet vedtaget - og det var vi 99,9 procents sikre på at det ville blive - så ville vi rejse os og bukke for folketinget og gå. Altså en stille, men markant cadeau til dem alle.” Interview Hansen.

$5^{8}$ "Det var skide skægt ... Den dag tænker man, det var indsatsen værd, i alle de år, sådan blev det kronet med held.” Interview Hansen.

59 "Så fik de papir på kærligheden," Berlingske Tidende, 2 October I989. Cf. Søland I998.

60 Friele 1975, 86-92; Olsen $1983,5^{\mathrm{I}-52}$.

6r "Istedenfor å imøtekomme lesbiskes behov og interesser, fløy lesbiske tillitsvalgte på ‘sikrere seks'-møter og lærte kunsten å tre på kondomer!” Friele ı990, 298.

62 "AIDS-trusselen krevde 'moderne' homopolitikk utført av unge medarbeidere. I land etter land ble opposisjonelle gammelaktivister gitt løpepass. PC'er i hundretusen kroners klassen, hvite skrivebord og oppsatser med grønne busker, vidnet om sannheten i det gamle ordtak: 'Aldri så galt at det ikke er godt for noe!'” Friele I990, 298.

63 "Første gangen jeg og Gro Lindstad som da var nestledere bestemte os for at vi ville ta opp og utfordre det standpunktet DNF hadde, å må ikke gå for ekteskap. Da mobiliserte Kim veldig og det ble en masse greier og da endte vi jo opp med det der vedtak at vi skulle slåss for alle som bodde sammen av ulike årsaker." Interview Øie and Sørensen. 
64 "Det er jo en ting å være ideologisk motstandere men når du skal begynne å meisle ut hva betyr det da i praksis så trur jeg nok det blir vanskeligere." Interview Øie and Sørensen. Friele 1990, 304.

${ }_{5}$ "KRF var ikke noen vits å bruke tid på, Fremskrittspartiet, ja der var det en og anen, men de andre bearbeidede vi." Interview Øie and Sørensen. Interview Halvorsen.

66 Stortingets Forhandlinger 1992-93. Forhandlinger i Odelstinget nr. 37, 29 March 1993, p. 54I.

67 Friele comments her decision to register in Chapter Two. See p. 88."Til lykke, partner," Aftenposten, 6 August 1993; "Vakker og romantisk partnerskapslov," Nordlys, 7 August 1993. 68 Dette har vi ventet på," Stavanger Aftenblad, 7 August 1993; "Stor stemning under partnerskapseremoni," Rogalands Avis, 7 August 1993; "Vakker og romantisk partnerskapslov," Nordlys, 7 August 1993; "Partnerskapsloven - en milepæl," Nordlys, 9 August 1993. Interview $\varnothing$ ie and Sørensen.

69 "Registrerat partnerskap för homosexuella," Dagen, I9 June I990; "Homosexuella par tillåts ingå äktenskap,” Östersunds-Posten, I9 June I990; Homosex-äktenskap legaliseras," Dagens Nyheter, I9 June 1990.

70 Partikongress 1992. Swedish Social Democratic Party Print. Arbetarrörelsens Arkiv och Bibliotek (ARAB), Stockholm.

7I "Det var vi emot, för vi tyckte det var ett sätt att begrava frågan. Vi blev alldeles fnattiga när vi fick höra att Barbro Westerholm hade tackat ja till ordförandeuppdraget. Det är ju tämligen ovanligt att en socialdemokratisk regering tillsätter en utredning med en borgerlig ordförande. Och vi tyckte att det här var försåtligt, för hon var ju en av dem som hade försvarat det här tydligast i riksdagen. Och nu skulle hon sitta fjättrad som ordförande i en utredning och behöva vara diplomat där och så att säga vara bortkopplad från politiken.” Interview Wikström.

72 Westerholm 2000, 250. Interview Westerholm.

73 SOU 1993:98. Westerholm 2000.

74 Westerholm 2000.

75 “När röstningen gick igenom och man såg siffrorna på tavlan då var jag så rörd så tårarna bara trillade samtidigt som jag febrilt skrev upp siffrorna eftersom jag behövde ha dem med mig tillbaka till kontoret. Och mitt i detta stora emotionella kaos så friade Jeanette till mig!" Isaksson and Lennerhed (eds.) 2007, 69.

76 "Partnerparet tog t-bana hem," Svenska Dagbladet, 3 January 1995; Interview Spaak; "Att älska i nöd och lust ..." Östersundsposten, 3 January 1995; "Tidaholmspar först ut med att registrera partnerskap," Skaraborgs Läns Allehanda, 3 January 1995.

77 Interview Svahn; "Att älska i nöd och lust ...” Östersundsposten, 3 January I995; "Tidaholmspar först ut med att registrera partnerskap," Skaraborgs Läns Allehanda, 3 January 1995.

78 “Ny lag om partnerskap kräver ny typ av tårta," Svenska Dagbladet, 7 January 1995.

79 Alpingistíðindi 1985-86, A-2, column 940-4I; Alpingistíðindi r985-86, B-2, col. I791-96; Einarsdóttir 2008, 103.

80 "Fordi jeg tænkte at det ville være bedre for denne sag hvis jeg kunde finde en fra hvert parti, så det ikke blev bare mit parti. For så ville det jo ses som en sidesag fordi det bare var Kvindelisten." Those who signed the proposal together with Ingibjörg Sólrun were Össur Skarpheðinsson from the Social Democrats, Einar Guðfinnsson from the Independence Party, Guðrún Hélgadóttir from the People’s Alliance, and Ólafur Porðarsson from the Progressive Party. Interview Sólrun Gísladóttir. 
8I Skýrsla 1994; Alpingistidindi 1995-96, col. 7533-34. Kristinsson 2000. Traustadóttir and Kristinsson 2009.

82 Interview Eddudóttir.

83 Einarsdóttir 135. According to Guðrún Gisladóttir, it was she who gave Samtökin'78 the idea to put the new law in force on Christopher Street Day. Interview Gisladóttir.

84 In reality, there were (at least) four couples, since Lana Kolbrún Eddudóttir and her girlfriend Jóhanna registered quietly at home. Lana was tired of being the official face of the partnership law, and preferred a calm ceremony. Interview Eddudóttir.

85 "Ógleymanlegur hamingjudagur," Dagblađið Visir, 28 June 1996.

86 "Baggrunden for anmodningen er, at det i år er FN's familieår, og det er vigtigt at fastslå, at der findes andre familieformer end den egentlige kernefamilie." Henriette Rasmussen. Landstingets forhandlinger, 2I February 1994.

87 "Hvis insekterne får indsigt i det her, vil de nok grine af os, selv de aller mindste skabninger ved, ud fra deres skabelse, hvordan livet skal videreføres.” Nikolaj Heinrich, Issittup partiia. Landstingets forhandlinger, 2I February 1994. "Angutaannaasartut arnaannaasartullu aappariittalernissaat / Bøsser og lesbiske skal kunne indgå ægteskab: Religiøse grupper i Nuuk protesterer," Sermitsiaq, I8 February 1994. For a thorough discussion about sexual culture and legal regulation of sexuality in Greenland, see Rydström 2007a.

88 "Angutaannaasartut akuerineqarput / Ja til bøsser," Atuagagliutit / Grønlandsposten, 24 February 1994; "Aappariittut nalunaarsorneqarsinnaalerput / Bøsser og lesbiske kan nu få papir på deres samliv," AG, ${ }_{25}$ February 1994; "Akuersaarneqannginneq artornartorujussuuvoq / Svært når homoseksuelle ikke bliver accepteret," Atuagagdliutit / Gronlandsposten, 22 July 2004; "Uagut aamma inuuvugut... / Vi er også mennesker..." Atuagagdliutit/ Gronlandsposten, I March 1994; "Tamanna qaqutigoortuunngilaq / Homoseksualitet er slet ikke så sjældent endda," Atuagagdliutit / Gronlandsposten, 9 March 1994; Journal nr. 1994-7770०००2, Justitsministeriet, København.

89 Rydström 2007a, 156.

90 "Ráðstevna: - Hvør fuglur syngur við sínum nevi," Dimmalatting, 22 August 2005; "Guds fyriskipanir broytast ikki," Dimmalatting, 22 August 2005; "Grát mítt elskaða land," Sosialurin, 24 August 2005; "Røðan hjá Hans Paula Strøm,” Dimmaletting, 24 August roo5; "Villa og synd?" Dimmalatting, 26 August 2005; "Guds "Niðurgering av samkyndum átti verið ólóglig," Dimmalatting, 6 September 2005.

9I Only one of the two women in the Løgting, Karin Kjølbro from the Republican Party (Tjódveldisfokkurin), voted for the anti-discrimination law in 1988. Shortly after this, Kjølbro left politics, disgusted with the conservative atmosphere in Faroese politics. Interview Kjølbro. Løgtingstiðindi I987 A:232; "Kynsstríð elvt til samgonguslit," Dimmalatting, 26 March I988; “Orsøk til samgonguslitið," Dimmalatting, 7 May i988; "Uppískoyti um 'seksuel orientering' í revsilógini," Sosialurin, 30 March 1988.

92 "Samkyndu fingu ikki innivist í revsilógini," Dimmalatting, I4 December 2005.

93 "Merkini siga hvussu tað er at vera samkyndur í Føroyum," Dimmalatting, 28 September 2006; "Groft overfald åbner færøsk homo-debat," Politiken, 9 October 2006; "§ 266b: Kynslig orientering verður skoytt uppí revsilógina,” Dimmaletting, 15 December 2006.

94 The Faroe Islands have long demanded full membership in the Nordic Council, instead of the observer status they now have. This question was up for discussion when the homophobic attack in 2006 turned the other member states' attention to the fact that the Faroes lacked a clause against discrimination on grounds of sexual orientation, and this was used against them in the following debate. "Orðaskifti um samkynd avmarkaða umtalu utan- 
lands," Dimmalatting, 8 November 2006; "Homofobi: Nordisk Råd kritiserer Færøerne," Information, I November 2006.

95 Mustola 2007, 216.

96 Tuula Juvonen has discussed the crisis of Finnish masculinity after World War Two. See Juvonen I998; idem 2002, 85-94. The prohibition of encouraging homosexuality was rarely used, but it served as an efficient incentive to self-censorship. Ulf Månsson has reported how the gay and lesbian activists at the time tried in vain to be prosecuted for it. Interview Månsson.

97 Halonen 1980; Mustola 2007, 243.

98 Perhekomitean mietintö 1992; Mustola 2007, 242.

99 "Jag måste medge att det var jag som skrev den första lagmotionen ... Men det var inte så lätt att få med sig riksdagsledamöter. Det var kanske ett tiotal som var beredda underteckna." Interview Hentilä. The bill was signed by Outi Ojala, Marjatta Stenius-Kaukonen, Claes Andersson, and Esko Helle from the Left Alliance; Tarja Halonen, Virpa Puisto, and Erkki Tuomioja from the Social Democrats; Heidi Hautala, Tuija Maaret Pykäläinen, and Ulla Anttila from the Green Alliance; and Jörn Donner from the Swedish People's Party. Eduskunta 1993. Lakialoite / Lagmotion 4/1993.

Ioo "Suomen ensimmäisiä homo- ja lesbohäitä vietettiin Helsingissä," Etelä-Saimaa, I4 August 1994; "Homosexuella 'gifte sig' i Helsingfors," Jakobstads Tidning, I4 August 1994. Interview Lehtonen and Mustola.

IOI Interview Hiltunen (in English).

I02 Interview Kivinen (in English); Interview Lehtonen and Mustola (in English).

I03 The effect of Dahlgren and Attling's marriage was so great that lesbian activist Kati Mustola jokingly has referred to the Finnish law of registered partnership as "Lex Dahlgren." Personal communication with Kati Mustola, 5 January 20Io. "Registrerat partnerskap är en fråga om rättvisa," Nya Åland, 22 February 1996; "Häkämies homopareista: 'Homosuhteita virallistetaan ainoastaan Pohjoismaissa'," Ilta-Sanomat, 26 February 1996; "Rekisteröinti vai ei?" Salon Seudun Sanomat, 27 February 1996.

IO4 "ingenting kommer at hända i den här frågan under den här regeringens tid." "Homosexuella får vänta länge på registrering," Hufvudstadsbladet, Io May 1996.

I05 Laki ja samaa sukupuolta olevien parisubteet 1999.

ro6 Kati Mustola. Personal communication, 6 September 2005.

Io7 In addition to the 99 votes in favour and 84 against the new law, there was I abstention and I5 absentees. "Eduskunta hyväksyi parisuhdelain," Savon Sanomat, 29 September 20or; Interview Mustola.

Io8 “Oman näköinen unelma," Z-lehti no. 2 (2002), pp. I4-2I.

Iog Since no official party was arranged, Finnish television channels had to ask for permission from individual couples to get wedding footage to illustrate the new law. It so happened that the first couples who consented to this were two gentlemen in tailcoats, and another gay couple who ran a dairy farm. The latter couple was dressed in cotton shirts and woollen vests adorned with textile applications of cows. The contrast between the two couples could not be greater, but these were the images that for a long time illustrated all news items on gay marriage in Finland. No lesbian couples allowed the TV cameras to be present, but later the same year Helsingin Sanomat needed pictures for a feature article on lesbian couples who registered their partnership. The only lesbian couple who let their wedding photos be published was Hannele Lehtikuusi and her partner Hanna Räty, together with their two sons. Personal communication with Kati Mustola, 5 January 2010. "Vi hör ihop - nu gifter vi oss," Hufoudstadsbladet 8 March 2002. 
IIo For an interesting discussion of external stereotyping of Sweden in the I950s and I960s see Glover and Marklund 2009.

III Broberg and Roll-Hansen 1996; Koch 2000; Tydén 2002.

\section{Notes chapter 2}

I "Skulle det icke vara tänkbart, att en undantagsställning kunde beredas åt sådana människor, som äro mina likar, så att om de kunde finna någon varelse av deras eget kön, som kunde besvara deras kärlek, dessa då finge ingå äktenskap med varandra? . . . O människor, människor, varen barmhärtiga! Jag vet, vad Bibeln säger, men gives för undantagsmänniskor ingen undantagsställning? Då jag skulle kunna mottaga denna förbindelse under Guds tacksägelse och en annan skulle kunna göra detsamma med mig, varför skulle vi icke få det?" (Emphasis in original.) Wikner 1971, 66. For a longer discussion about Wikner, see Rydström 2003, $43-47$.

2 Thorsell I981; Rydström 2003, 52-53; Mustola 2001.

3 In 1955, Danish police raided the home of the leader of The Society of I948, Axel Lundahl Madsen (later Axel Axgil), who also was owner of a firm that distributed soft-porn photographs. The police confiscated his address lists, resulting in the prosecution of many of his customers for illegal homosexual acts with persons under $\mathrm{I} 8$, as well as a prison sentence for Lundahl Madsen. Axgil and Fogedgaard 1985, I05-31; Rosen I999; idem 2007, 7577 .

4 It also included a prohibition to "promote" (fremme) homosexuality with a wording that in practice would make it impossible to run an association for homosexuals. Halsos 200I, 65-74; idem 2007, 96-99; Kristiansen 2008, 182-89. In connection with the proposal to decriminalise homosexual acts, the Norwegian Bishops' Meeting in 1954 declared that Norway stood "before a social danger of global proportions" (overfor en samfunnsfare av verdensdimensjoner). Halsos 200I, 7r. The measures to counteract the actions and organisations of homosexuals were proposed during the wave of homophobia that swept over the Western world in the I950s. Cf. Moxnes 200I.

5 In a letter to the board, Allan Hellman, one of the founding members, commented on the letter to the Government saying that "according to information I have obtained it will harm us and has already harmed us considerably." (Enligt vad jag har erhållit kännedom om kommer den att skada oss och har redan skadat oss i högst väsentlig grad.) The importance of this letter seems to have been somewhat exaggerated by earlier historians. RFSL sent a letter to the Government in June 1952 demanding rights for homosexuals. What could be interpreted as their claim for marriage is a passage that reads: "If and how homosexual relationships can be legalised is also important to investigate. Permanent relationships would diminish boy prostitution considerably, which is of general social interest." In the end the letter suggests that the Government appoint a committee to investigate "what the state can do to grant its homosexual citizens the same social and human rights as heterosexuals." (Om och hur homosexuella förbindelser bör legaliseras är det också av vikt att utreda. Fasta förbindelser skulle väsentligt minska pojkprostitutionen, vilket är ett samhällsintresse ... vad statmakterna [sic] bör göra för att bereda de homosexuella medborgarna samma sociala och mänskliga rättigheter som de heterosexuella.) Hellman's letter to the board was written much later and it is not clear which letter he refers to. There is no copy of any other letter to the Government in RFSL's archive from that period, and a search in the diaries of incoming mail of the ministries of Social Affairs, Church, and Justice has proved 
negative. The only letter from RFSL to the Government is a letter of June 24 registered in the incoming diaries of the Ministry of Social Affairs, arrived 26 June 1953. Stig-Åke Petersson refers to the minutes of RFSL's board in an article from 2000, saying that RFSL petitioned for marriage. Petersson 2000, 29. William Eskridge and Darren Spedale repeat the story based on an interview with Petersson. Eskridge and Spedale 2006, 69. RFSL to the King in Council, 24 June 1952, vol. E r:I, RFSL's Archive, Swedish National Archive (RAS); Allan Hellman to the board of the RFSL, 27 December 1953, Raymond Staf to Allan Hellman, ir February 1954, vol. E 4:I, RFSL's Archive, RAS; Minutes of the Board, 3 January and I8 January 1954, RFSL's Archive, RAS. Inkommande diarier CIa 26 June 1952, Socialstyrelsen, RAS.

6 Kristiansen 2008, 18I-90.

7 Axgil and Fogedgaard 1985, I78-85; Kristiansen 2008, I49-56; Wasniowski 2007, 83 Petersson 2000,18 .

8 "Homosexelle ligestilles i boligkøen: Fordomsfrit initiativ af svenske studenter," $P A N$ bladet $\mathrm{I} 3$ (I966):2, 5 I.

9 "Medicinarklubb forcerar sexvallen," Hufoudstadsbladet, 3I March 1965; "Homosexualiteten och lagstiftningen," Hufvudstadsbladet, I3 August i966. In SETA Archives, Helsinki. Io "Der var to hovedområder hvor man kan sige man ikke havde ligestilling ... Og det andet område det var så den manglende mulighed for at indgå ægteskab, for at sige det sådan meget populært.” Interview Bønnelykke.

II "papirløse par . . . en udvidelse af ægteskabets retsvirkninger til en yderligere del af befolkningen ... To personer, der ønsker at leve i varigt samlivsforhold, kan kræve partnerskabet registreret af overøvrigheden. Registreringen (anerkendelsen) medfører på alle lovgivningens områder samme retsvirkninger som indgåelse af ægteskab. Forholdets anerkendelse kræver begge parters samtykke. Opløsning sker, hvis mindst en af parterne ønsker det, og følger samme regler som ved skilsmisse.” Letter from Per Kleis Bønnelykke to [Marriage Commission] chairman Bitsch, published in PAN-bladet no. 2, I971, p. 2.

I2 "Ikke ægteskab, men gerne en form for ligestilling," PAN-bladet, no. I (I97I); "Ægteskab - Partnerskab," PAN-bladet, no. 9 (I973).

I3 The Danish Marriage Law Commissions i969 published nine reports, but they did not result in any substantial law reforms. With the exception of some minor adjustments in I989, the law remains the same as after the major marriage law reform in 1925. Melby et al. 2006, 372 .

I4 "Der var altså en holdning der gik ud på at ægteskabet det var forbeholdt de heteroseksuelle ... Og så var der jo også især kvinder der mente at ægteskabet i sig selv var en gyselig indretning." Interview Bønnelykke.

I5 "Nei til homofile ekteskap ... Ja til homofile samliv - nei til ekteskap etter tradisjonelt mønster ... I. Enkeltmenneskets verdi er ikke avhengig av evnen, viljen eller muligheten til samliv med et annet menneske. 2. Det Norske Forbundet av 1948 kan ikke godta noen form for diskriminering av enslige - økonomisk eller menneskelig. Forbundet vil støtte enhver politikk som har som målsetting å fjerne denne diskrimineringen overalt hvor den gjør seg gjeldende. Det Norske Forbundet av 1948 vil samtidig arbeide for en sikring av andre samlivsformer enn det tradisjonelle ekteskapet." Referat av generalforsamling I973, Aa ooor, "Generalforsamling I953-I982," Det Norske Forbundet av I948 (DNF' 48). Privatarkiv I216. Riksarkivet, Oslo (RAN).

I6 "Hvilke alternative samlivsformer kan vi som lesber og homser inspirere til i framtida? Vi står utenfor kjernefamilien og kan kanskje på et friere grunnlag motvirke familiens pri- 
vatiserende rolle. Likeverdighet homo - hetero må være lik rett til seksualitet, ikke at vi skal adoptere kjernefamiliens idealer." Bergh and Jensen 1984, I8.

I7 Interview Pareli; Friele 2000, 63, n. 43.

I8 "Vi hade ingen värdering av äktenskapet i sig, utan vi tyckte att det som gäller för heterofiler ska gälla för oss också ... Om vi krävde äktenskap eller bara att reglerna skulle vara lika minns jag inte." Interview Petersson.

I9 "Det var kanske därför det var så lätt att få igenom.” Ibid.; SOU 1972:4I. The comments on RFSL's 1972 campaign are in RFSL's archive, vol. Familjerätt. RFSL.

20 "Både norrmän och danskar gjorde narr av oss. De var mer radikala." Interview Petersson. "De er litt mer sånn borgerlige, litt sånn forsiktige ... så vi gjorde jo litt narr av svenskene den gangen, så vi laget dem med skaut og blomsterpotte og sånn ... de ble stående mer ved det tradisjonelle ekteskapet. Men det var jo mye debatter landene imellom." Interview Friele.

2I "uten av [sic] vi av den grunn må være nødt til å gå med på det heterofile samfunnets premisser." "Kjempers fødeland, regulering av samliv, Kim Friele, Sverige og annet," Løvetann no. 2, I982, 46-47; "Ekteskapsdebatten - og noen kommentarer til Calle Almedal," Løvetann no. 3, 1982, 37-38.

22 "eru andvíg pví að lesbíur og hommar taki upp óbreytta pá skiptingu í hjónafólk og annað fólk, sem gerir greinarmun á fyrsta flokks og annars flokks borgurum ... Hins vegar telja pessi félög að fólk í sambúð skuli, án tillits til kynferðis eða fjölda, fá að skipa einkamálum sínum, p.m.t. fjármálum, með peim hætti sem pað kýs." "Fundur í Norðurlandaráði lesbía og homma.” Copenhagen, December i98r. Samtökin '78. BR.

23 "hálfan hlut ... Nú eigum við aftur að verða til með takmörkuðum réttindum að mati meirihluta nefndarinnar ... svo við látum ekki skammta okkur lýðréttindi annars flokks pegna til eilífðar" "Okkar mesta gleði, okkar mesta sorg," Sjónarhorn, No. 3 (1994), 6-7.

24 Einarsdóttir 2008, I2I; Interview Eddudóttir; Skýrsla 1994, 65-68.

25 "Hvad skal vi med det borgerlige ... ja pis!? . . Nej, vi var stærke kvinder, som ku' selv og hoad havde kvinderne arbejdet for i hele halvfjerdserne? For at blive selvstændige, at blive værdsatte, at blive sig! At blive noget i sig selv, ikke som vedhæng til en eller anden anden.” Interview Slange. In Sweden, ethnologist Ingeborg Svensson has done research on the situation for families when young gay men died of AIDS. Svensson 2007.

26 There were of course other, less ideological and more personal, reasons for lesbians to oppose the law on registered partnership already in the I970s and I980s. The wish to have children was strong in many lesbian women, and a law that would not include rights of parenthood seemed less interesting to them. See for instance "Jeg vil ha' et barn," $P A N$ bladet, no. 7 (I970).

27 Hartmann 1997 (I979), II4.

28 Radicalesbians. "The woman-identified woman.” Special Collections Library, Duke University. ALFA Archives Box I2. Accessible at http://scriptorium.lib.duke.edu/wlm/wo$\mathrm{mid} /$. Viewed 8 January 2010.

29 "Att som lesbisk feminist stödja denna patriarkala institution - äktenskapet - vore ett hån mot kvinnans frigörelse." Lesbiska feminister to Utredningen om homosexuellas situation i samhället. N. d. Vol. I8. YK 3719. Riksarkivet, Stockholm (RAS).

30 Man var inte så intresserad av partnerskapslag och jag tror en orsak var att det fanns på den tiden bland lesbiska kvinnor radikalfeministiska tankegångar . . och allt som kunde påminna om äktenskap var det si och så med att man ville inte adoptera de former som heterosexuella hade." Interview Hentilä.

3I Interview Saarinen (in English). 
32 Dom fanns ju som inte alls ville gå med i .. patriarkatets äktenskap. Som inte ville delta. [...] 'Inte ska vi låta oss trängas in i äktenskapet som de heterosexuella och gå som får mot -- döden ... Interview Eddudóttir.

33 Cvetkovich 2003.

34 Interview Slange.

35 Interview Kristinsson (in English). Note that the Icelandic letter P corresponds to Th. I have chosen to keep the Icelandic spelling except in the list of references, where Thorvaldur Kristinsson is spelled in English.

36 "Killarna fick finna sig i att tjejerna tog mera plats. Och de behövdes för att hålla arbetet igång. Vi skulle ju hjälpas åt, eller hur?” Interview Eddudóttir.

37 Interview Saarinen (in English).

38 "Ja, jag upplevde det väl ofta som att det var jobbigt att jobba som tjej bland killarna, med den här dubbelt manliga jargongen och med ett väldigt litet intresse för kvinnofrågor på den tiden. Så man fick kämpa som fan här, och sedan så ett ständigt misstänkliggörande över huvud taget från kvinnorörelsens sida ... så såg ju de att killarna fick jättemycket pengar, det satsades jättemycket på informationsmaterial till killar, det var kukar på varenda vägg och överallt och det var kondomer och det var manlig sexualitet så att man bara spydde." Interview Mohr.

39 The organisation Lesbian Movement (Lesbisk bevegelse/Lesbisk bevagelse) was a Nordic lesbian coordination network, which was founded at the lesbian summer camp on Femø in 1974. It organised mainly Danish and Norwegian women and it still existed in the r98os, but had less to do with the national organisations.

40 "Det afgørende det var de homoseksuelles egen - bøssernes egen identitetsdannelse, selvforståelse. Altså en kamp imod selvhadet og en selvopfattelse som man jo nu og her, næsten et halvt århundrede efter måske har svært ved at forstå . . . med sådan en vis ligegyldighed og venlig interesse ... de syntes det var negativt. Det var at efterligne det borgerlige ægteskab som vi ikke sku' gå ind for eftersom vi var venstreorienterede og socialister og måske kommunister for nogles vedkommende ... Vi ville først og fremmest ændre på de homoseksuelle selv. Det var vores primære opgave. Selvfølgelig også de heteroseksuelle og ... men det fortalte vi jo bare brutalt, hvad vi syntes om dem ... at de havde undertrykt os, at de var forfærdelige, at deres livsstil var gysende, og at vi opfattede dem som fjender. Det kunne ikke være anderledes. Og hvis de syntes at det var overdrevet så var vi ligeglade med det." Interview Rosen.

4I "homosexuella proletariatet ... Vad som förvånar mig så här långt efteråt är att jag inte kan erinra mig några negativa kommentarer från förbipasserande ... Männen log blygt och tackade ja till salladen, men avstod vänligt men bestämt från att 'komma ut ur buskarna' och upp till vår filt för att sjunga 'Befrielsen är nära." Eman 2000, I6o. The song "Liberation is near" (Befrielsen är nära) was the lead song from the successful women's lib musical "Jesus, girls! Liberation is near!" (Jösses fickor! Befrielsen är nära), written and directed by Suzanne Osten, staged at Stockholm City Theater in 1974.

42 "Killarna tyckte att det här var det dummaste vi kunde hitta på, alltså . . . Och man måste förstå det här utifrån våra känslor. Vi har ju de flesta av oss .. den äldre generationen, som ju är fyrtio nu, blev ju utstötta ur våran egen familj. Och jag tror många blev så sårade att de ville överhuvud taget inte göra som alla andra. De ville inte normaliseas." Interview Eddudóttir.

43 The Nordic Council for Homosexuals was founded in 1980 and for many years was a lively network consisting of activists from the various gay and lesbian organisations in the Nordic countries. They lobbied the Nordic Council of Ministers in gay and lesbian mat- 
ters. One of their main objectives was to make the other Nordic countries put pressure on Iceland and Finland to liberalise their legislation. It has not been active for many years. 44 "Spørgsmålet er, om det er muligt at bekæmpe diskriminationen af os (den kendsgerning at vi bliver behandlet anderledes) uden at opgive ideen om, at vi er (og har ret til at være) anderledes ... Problemet er ikke, om vi ønsker at blive accepteret, det er nødvendigt for os. Men problemet er, om vi vil accepteres som en livsform lig den heteroseksuelle livsform (undtaget nogle mindre detaljer), eller om vi vil accepteres som en ligeværdig med [sic] anderledes kultur ... bevare og udvikle vores bøsse/lesbiske kulturer." Sanne Yde Schmidt, Copenhagen I988. Askja I3. Samtökin '78. Borgarskjalasafn Reykjavíkur (BR).

45 "Och alla organisationerna såvitt jag minns var enhälligt och utan ens att tänka på saken, för det fanns inte som alternativ, emot registrering i särskild ordning, utan det var äktenskap eller intet.... Och det var ju självklart att vi inte skulle ha en särlagstiftning på något sätt." Interview Mohr.

46 "Alternativet innebär de facto att ett särskilt regelsystem införs för den homosexuella samlevnaden, vilket måste uppfattas som direkt diskriminerande.” RFSL to Utredningen om de homosexuellas situation i samhället, 2 June i98r. Vol. 18. YK 3719. RAS.

47 "alla former av särlagstiftning för homosexuella ... Vi tycker det är ohederligt när man beskriver registeräktenskapet som något annat än ett B-äktenskap, ett surrogat som kan bli bättre eller sämre beroende på hur välvillig lagstiftaren kan tänkas vara.” Homosexuella Socialister to Utredningen om de homosexuellas situation i samhället, 26 April i98r. Vol. I8. YK 3719. RAS.

48 “anmälnings- eller registreringsförfarande . . k konservering av fördomar." EKHO to Utredningen om de homosexuellas situation i samhället, 3 May 198r. Vol. I8. YK 3719. RAS. 49 "beroendeställning, passivitet, uppoffring och identitetslöshet ... pressas in i äktenskapet." Lesbiska feminister to Utredningen om homosexuellas situation i samhället. N. d. Vol. I8. YK 3719. RAS.

50 "Det var ju naturligtvis för att få ut det mesta möjliga av något - en glädjefylld landvinning, men det har ju också en politisk taktisk finess så att säga. 'De försöker kalla det här något diminutivt men vi kallar det att gifta oss'... Nu skulle jag inte kalla det att vi får gifta oss. Nu kämpar vi ju för ett riktigt könsneutralt äktenskap." Interview Wikström.

$5^{\mathrm{I}}$ The interview with Porvaldur Kristinsson was made in English, and the quotes are taken verbatim from the tape recording. Both Kim Friele and Porvaldur Kristinsson have had the opportunity to read and comment on this section. Porvaldur has taken the opportunity to correct some minor factual errors, and also to correct some of the wording in his quotes.

52 Porvaldur Kristinsson, e-mail correspondence, 9 November 2009.

53 Ibid.

54 Conference on gay marriage 1973. Friele's Archive; Referat av generalforsamling 1973, Aa ooor, "Generalforsamling I953-I982," Det Norske Forbundet av I948 (DNF'48). Privatarkiv I216. RAN; "Samliv i Norden," PAN-bladet, no. 6 (I973).

55 "Mitt råd til landsstyret var at det vi burde jobbe for var lovregulering av homofilt og lesbisk samliv ... Jeg syntes at når vi hadde så god tid på oss, burde vi kritisk vurdere om ekteskapsloven faktisk inneholder en del rettsvirkninger som er helt umulige for oss å ta sikte på.” Interview Friele.

56 "den tok ikke med barna ... Jeg mente at vi måtte ikke være så giftekåte annet enn at vi skulle vente til vi hadde fått med oss ungene ... I dag kalles partnerskapsloven av dem som stred den frem, for et B-ekteskap! Da jeg sa det samme i slutten av 80-årene og begynnelsen av 9o-årene, ble jeg jo nesten skutt, ikke sant?” Interview Friele. 
57 "Så kan du si: skulle vi ha ventet i ti år? Nei vi skulle vel ikke ha ventet i ti år. Men vi skulle vært modige og redelige nok til å ha diskutert det godt og grundig i homobevegelsen.” Interview Friele.

$5^{8}$ "Jeg synes den norske homobevegelsen er litt 'satt' - med hus og puddel og hage og... det er ingen virkelig brennbare homoideologiske politiske debatter lenger.” Interview Friele.

59 The conflicts between Friele and the new leadership of the Norwegian gay and lesbian movement were not primarily about the law on registered partnership. Instead, they involved Friele's position as Secretary General of the movement, her leadership style, and a number of other things. In this context, however, I emphasise the differing opinions about the partnership law.

60 "Mange syntes vi var svikere. Mange syntes vi hadde sviktet dem ved å inngå partnerskap - for barna var på plass ... og mange andre brukte motsatt argument: Hvordan går det an at dere som var imot partnerskapsloven er så freidige at dere inngår partnerskap? $\mathrm{Og}$ vi svarte: 'Sånn er det. Vi har ingen barn, men vi har gjeld og hus'... Vi gjør dette. Nå skal vi ta vare på kjærligheten - og det har vi gjort." Interview Friele.

\section{Notes chapter 3}

I For instance, the Swedish New Democracy, created for the elections in 1991, had two openly gay activists who were expelled in its first year of existence. "Jag trodde faktiskt att vi kommit längre än så," Expressen, 6 August 1991. In contrast, a member of the Norwegian Progress Party, Jan-Erik Fåne, was one of the five young MPs who signed the first private bill demanding a partnership law. He later left the party when it was being purged of too neo-liberal elements, and the conservative forces took a steadier grip on it. Interview Jensrud.

2 This oversimplified description of the Scandinavian party systems leaves out some important nuances. For instance, Scandinavia's first populist right-wing party was the Finnish Rural Party (Suomen Maaseudun Puolue / Finlands Landsbygdsparti) under Veikko and Pekka Vennamo. It was founded in 1959 as a reaction to perceived urban dominance in politics and got I0.5 percent of the votes in the elections of that year. Its ideological successors are the Real Finns (Perussuomalaiset/Purfinnarna). Another exception to this description is that the Norwegian Christian People's Party, founded in 1933, has since long been a major player in Norwegian politics. Arter 1999; Karvonen 1993. Cf. Arter 2008. Esping-Andersen 1985; Rokkan 1970; Grofman and Lijphart 2002; Demker and Svåsand (eds.) 2005; Antorini 2008. For the Finnish political system, see Hodgson 1967; Mylly and Berry (eds.) I987; Nygård 2003; Sundberg 1996; Mayes 2004.

3 The usual left-right spectrum in politics is insufficient to describe the situation in Iceland, the Faroes, and Greenland, where the question of independence or cooperation with Denmark has created another axis. In Iceland, the moderately conservative Independence Party (Sjálfstadisflokkurinn) and the agrarian-centre Progressive Party (Framsóknarflokkurinn) traditionally have been in favour of modernisation and West-oriented politics, whereas the political left has emphasised traditional Icelandic values combined with criticism of Iceland's NATO-membership. The People's Alliance (Alpýdubandalagið) was created in 1956 after a fusion of the successor of the Communist Party, the People's AllianceSocialist Party (Sameiningarflokkur alpýdu-Sósialistaflokkurinn), with a splinter group from the Social Democratic Party (Alpýduflokkurinn) and gained considerable influence in Ice- 
landic politics. In 1983, Iceland saw the emergence of the only successful feminist party in Scandinavian politics, the Women's List (Kvennalistinn), which had a decidedly pro-gay stance. Faroese political parties are even more grouped around the independence question, with one moderately socialist party, the Republicans (Tjódveldi), and one liberal party, the Independence Party (Sjálvstýrisflokkurin), working for full independence from Denmark. The conservative People's Party (Folkaflokkurin), the liberal Unionist Party (Sambandsflokkurin), and the Social Democrats (Javnadarflokkurin) have a less radical line concerning independence, or are explicitly working to develop Danish-Faroese relations. The Christian Centre Party (Midflokkurin) strongly emphasises traditional values and is, as such, suspicious of liberal or pro-gay legislation coming from the Danish Government. All Faroese political parties are split over gay and lesbian rights issues, but none is willing to sacrifice a government to promote LGBT interests. Interview Hoydal. In Greenland, the party that has dominated politics since the Home Rule Act was adopted in 1979 is Siumut, a social democratic party. The liberal-conservative Atassut has been more in favour of keeping the link with Denmark, while left socialist Inuit Ataqatigiit (IA) has favoured total independence. The liberal party Demokraatit was created before the elections in 2005 and gained votes by challenging Siumut's long government. The independence question in Greenland has been focused on Greenlanders' right to their natural resources, and from 2009, Home Rule (hjemmestyre) was replaced by Self Determination (selvstyre). In the first elections after the Self Determination Act became effective, Siumut lost power to IA. Karlsson 2000; Interview Hoydal; Interview Rasmussen.

4 "Men jeg tror, at de, der faktisk eksisterer, får en bedre, en mere menneskeværdig tilværelse, hvis man fra samfundets side siger: ja, vi ved, at I findes, vi ikke alene tolererer jer, vi kan også se, at I har visse problemer, som vi gerne igennem lovgivningen vil være med til at løse." Poul Dam, Folketingstidende 1968-69. FF col. 676.

5 "Staten bör erkänna själva existensen av sådana samlevnadsformer men inte rättsligt reglera dem." Riksdagen 1973. Mot. 1873:I793.

6 "en samlevnad mellan två parter av samma kön är från samhällets synpunkt en fullt acceptabel samlevnadsform.” Riksdagen 1973. LU 1973:20.

7 Riksdagen I973. Mot. 1973:I793, p. 2; Bet. 1973:LU20, p. Ir6; Prot. I973:Io6, p. 37, I June I973.

8 Bergh and Jensen 1984.

9 "Som kommunistar og revolusjonære hevdar vi at klassesolidariteten, og korleis ein stiller seg i klassekampen, er overordna kva for slag seksuell legning ein har. Når ein skal vurdera dei homofile si stilling i samfunnet, må ein difor taka utgangspunkt i kva klassetilhøve ein har. ... Samstundes ynskjer ikkje partiet å presse homofile til å endre si legning. Berre ei vitskapeleg analyse på marxismen-leninismen Mao Tsetungs tenking si grunn, og einskap om denne tufta på viljugskap og overtyding, kan løyse motseiingar på dette omkvervet fullt ut." Framlegg til fråsegn om homofili, quoted from Friele 2004.

Io 'alt som smakte av 'kvinneseparatisme', homosjåvinisme', 'politisk lesbianisme', og humor." Quoted from Friele 2004. Bergh and Jensen presents a similar quote without indicating its source: "everything that smacked of sexual liberalism, homo chauvinism, and women's separatism” (alt som smakte av 'seksualliberalisme, homosjåvinisme og kvinneseparatisme). They also mention humour as an undesirable component in the political struggle for lesbian and gay rights. Bergh and Jensen 1984, I6.

II Friele 2004. Ah Eksklusjonssaken. Det Norske Forbundet av 1948. Privatarkiv I2I6. Riksarkivet. Oslo. 
I2 "Men situationen i det finska samhället var annorlunda då. Jeremy Thorpe-skandalen hade ägt rum i England och han hade tvingats avgå på grund av kontakter med en manlig prostituerad. Jag tänkte att man kunde hänvisat till den historien om jag varit öppen." In the same interview he correctly predicted that the abolition of the encouragement ban could happen near the end of the I990s. "Jorma Hentilä, folkdemokrat: Förändringen kommer i slutet av 9o-talet," Reporter No. 2, 1989.

I3 Interview Hentilä.

I4 "Arbetarrörelsen borde skärpa sej!" Ny Tid, 23 July i98r.

I5 "När jag blev partisekreterare visste de som valde mig att jag var homosexuell. Men när jag blev ordförande [i SETA] 1983 kom en del negativa reaktioner från partikamrater. Några i distrikten ville skriva protestbrev till ordföranden.” Interview Hentilä.

I6 Alpingistidindi 1985-86, A-2, col. 940-4I; Alpingistidindi 1985-86, B-2, col. 179I-96. The Socialist Alliance was the first party that put lesbian and gay rights on its political agenda, and former chair of Samtökin '78, Guðni Baldursson, was on their Reykjavík list.

I7 "For det var en forbindelse mellem kvindekampen og den kamp homoseksuelle havde for sine rettigheder. Det var sådan en kamp om menneskerettigheder og jeg syntes det var en stor forbindelse mellem disse ting." Interview Sólrun Gísladóttir.

I8 Alpingistidindi 1995-96, 6 March 1996, col.3764; Thorvaldsdóttir 2007.

I9 "Johanna Sigurdardottir, world's first openly gay leader, to take office in Iceland," Times Online, 29 January 2009. http://www.timesonline.co.uk/tol/news/world/europe/article56ro520.ece, viewed 22 April 2010.

20 Rydström 2007a.

2I Rydström 2007a; Interview Hoydal; "Løgmaður og Hoydal: Einki skrásett parlag," Dimmalatting, 2 February 2008; E-mail communication with Høgni Hoydal, I4 December 2009 .

22 "en onaturlig företeelse som framvuxit ur speciella samhälleliga förhållanden ... dömda till sin undergång ... Vår tids uppåtstigande klass, det moderna proletariatet, den klass som är bärare av framtiden, den klass som skall störta kapitalismen och på dess ruiner bygga socialismen, den klass som slutgiltigt skall befria mänskligheten från utsugning, krig och förtryck och garantera människorna ett rikt materiellt och kulturellt liv, avvisar med förakt de borgerliga kvasivetenskapare, som upphöjer det som är naturligt för deras egen degenererade klass och deras eget undergångsdömda samhälle till något allmängiltigt och naturligt." "Till frågan om de homosexuella ... Kan homosexuella erhålla medlemsskap i KFML(r)?" Klasskampen No. 5, I973.

23 "offentligt försvarat den idealism som artikeln fört fram ... RFSL och dess inkrökta reformkamp i legalismens tecken, en reformkamp som inte så mycket som sneglar åt det faktum att vi lever i ett klassamhälle? ... dementerar artiklarna i vår press och gör grundlig självkritik för den inställning som man gett uttryck för." "Den eländiga filosofin i en underordnad fråga som homosexualiteten," Kampens Väg, No. 4-5, I974.

24 When Else-Merete Ross resigned from Parliament, The Society of 1948 sent her its best wishes and thankted her for her work for gays and lesbians in Denmark. PAN-bladet, no. 2 (I974); Andersen and Jensen 200I; Antorini 2008.

25 Demker and Svåsand (eds.) 2005.

26 "Homosexuella ska få rätt att registrera sina parförhållanden," Expressen, in November I990; "Homosexuellas äktenskap delar fp i Jönköping," Jönköpings-Posten, 23 January I99r; interview Westerholm.

27 Sundberg $1996,50$. 
28 "Homovänlig linje står fast,” Österbottningen, II June 1996; “"Vår åsikt om homopar kom bort," Vasabladet, I9 February 1999; "Riv upp partidagsbeslutet," Jakobstads Tidning, $20 \mathrm{Fe}-$ bruary 1999; "Svenska riksdagsgruppen godkänner registrering av partförhållanden,” Borgåbladet, 24 September 1999.

29 "Ved familie forstås en gruppe bestående af voksne mennesker med eller uden børn (Storfamilier og homofile ægteskaber indgår således også i dette familiebegreb).” Petersen 2000,227 .

30 "storfamiljer, syskonhushåll, homosexuella m. fl. . . Med familj avses då alla former av sammanboende med två eller flera individer." Familjen i framtiden 1974, 36. Interview Lööw.

$3^{\mathrm{I}}$ "Fordi det ... handlede om mindretal og rettigheder, det som er socialdemokratisk politik ... Og det har jeg altså tolket som at når det store gamle parti først beslutter sig, så sker der noget også i partiet.” Interview Gjellerup.

32 "Altså der er jo sjældent at befolkningen faktisk i sådan nogle spørgsmål i virkeligheden er forud for politikerne ... fordi det er sådan et lidt elitært spørgsmål, kan man sige sådan, mindretalsrettigheder." Interview Gjellerup.

33 Interview Jensrud.

34 "Trrrond! Kom hær! Nå gårr vi nerr og skrriver under .. du vet når vi har skreevet under så kan ikke di der komme og puse det ut!" Interview Jensrud.

35 "Men når det kom tilbake hadde vi dannet regjering og Grete Berget som var statsråd var for partnerskapsloven.” Interview Jensrud. Stortingstrykk 1990-91. Dok 8:50 (1989-90), ref. O.tid. 4, Innst. O. 26, O.tid 317-339 (2I March 199I). Stortingstrykk 1992-93. Ot.prp 32, ref. O.tid. 397, Innst. O. 70, O.tid. 495-54I (29 March 1993), Besl O. 82, L.tid 38-54 (I April I993). Lov av 30. april I993. Halvorsen and Teigene 2004, 4I-42; "Homoloven kostet et vassdrag," Bergens Tidende, 5 April 1998.

36 "Men tyvärr, applåden kom för tidigt. För det blir inget regeringsförslag i december ... Flera statsråd, med statsminister Carlsson i spetsen, ifrågasatte bland annat en av hörnstenarna i förslaget, nämligen att den nya 'sambolag' för heterosexuella som just presenterats riksdagen också bör gälla för homosexuella par som bor tillsammans." "Nya homosexlagen stoppad," Dagens Nyheter, 26 November 1986.

37 Swedish Social Democratic Party Print, Kongress I987, Motion 536, Motion 537, p. 85-88; ibid, Partistyrelsens Utlåtande, p. I77-78; § 52, p. 46; Minutes of the Party Steering Committee, 22 May 1987. Social Democratic Party (SAP). Archives and Library of the Workers' Movement, Stockholm (ARAB).

38 "Jag är trött på att höra kamrater i de egna leden benämna dessa motioner 'bögmotioner' . . a att det förslag till lagstiftning om registrerat partnerskap, som socialstyrelsen nyligen tagit fram, bör få en skyndsam behandling av regering och riksdag." Swedish Social Democratic Party Print, Kongress 1990, Protokoll A, p. 93. ARAB.

39 "Som jag minns det så var det ju framför allt kvinnor som stöttade den och män som uttryckte tveksamhet. Inte alla, men några stycken.” Interview Lööw; Voting Charts: Votering 978, 7 June 1994, 15:49. Ärende LU28, Moment r. Riksdagbiblioteket (RB).

40 Interview Hiltunen (conducted in English).

4I Interview Kivinen (conducted in English).

42 Interview Hiltunen (conducted in English).

43 Since the large Scandinavian Social Democratic parties could not form governments of their own, they made formal agreements with the agrarian parties in the I93os, agreements that got various labels in the different countries: the "Cow-Peddling" (kohandeln) in Sweden 1933, the Kanslergade-Treaty (Kanslergadeforliget) in Denmark 1933, the Crisis- 
Treaty (kriseforliket) in Norway 1935, and the "Red-Soil Government" (punamultahallitus / rödmylleregeringen) in Finland 1936. In Iceland, a "Green-Red" coalition of the Social Democratic Party and the agrarian-based Progressive Party was in office between I934 and I938 and carried out a number of important reforms. The political agreements between Social Democrats and agrarian parties were matched by agreements between the large social democratic trade unions and the employers' guilds in all Scandinavian countries. Gustafsson 2007 , 25I-3; Jonsson 2001 .

44 Arter (ed.) 20ora.

45 Widfeldt 20oI; "Topp-politiker: Jag är homosexuell," Expressen, 28 March 1995; "En man kommer fram ur skuggan: Topp-politikern om sitt liv som gay," Expressen, 30 March I995.

46 Interview Hiltunen. Arter 2oorb.

47 “Sp-ungdommen kjefter på sjefen,” Dagbladet, 4 March 1998; "Homse-jubel ... men Sp spriker fortsatt," Dagbladet, I9 March 20or; "Slik skal de styre Norge: De rødgrønne legger fram regjeringsplattformen," Dagbladet, I3 October 2005. Stortingets Forhandlinger 2007o8. Odelstingets møte den II juni 2008; Christensen 200I.

48 Andersen and Jensen 200I, 96.

49 Folketinget 2008-2009. B 36 Forslag til folketingsbeslutning om adgang til at ansøge om fremmedadoption for par i registreret partnerskab; "Uenighed i Venstre sikrer homoseksuelle adoption," Politiken, I7 March 2009; "Homoseksuelle jubler over flere bleskift." Politiken, I7 March 2009; "Rasende DF'ere føler sig ydmyget efter homolov," Politiken, I8 March 2009; Folketinget. Møde nr.86, Tuesday 4 May 2010.

50 Arter 1978; Zilliacus 200I; Frankland et al. (eds.) 2008.

5I Frankland et al. (eds.) 2008.

52 http://192.49.229.35/E2007/r/tulos/lasktila.html. Viewed 3 April 2010.

53 Interview Lehtonen and Mustola; Interview Hiltunen.

54 "Rassende DF'ere føler sig ydmyget efter homolov," Politiken, I8 March 2009; "Uenighed i Venstre sikrer homoseksuelle adoption," Politiken I7 March 2009; Antorini 2008.

55 "Endelig har jeg et privatliv," Verdens Gang, 28 May 1980.

56 "Av hensyn til den oppvoksende slekt er det galt å alminneliggjøre homoseksualitet. Tenk på alle foreldre som ikke ønsker at barna skal komme borti dette. Lowzow skulle selvsagt fortalt om sin legning før vi valgte henne første gang." "Lowzow vraket gjennom kupp: Høyrekvinner og homofile er rasende," Arbeiderbladet, 22 November i980.

57 "Homo-aksjon for Lowzow," Arbeiderbladet, 22 January 1985; "Lowzow må vike," Bergens Tidende, 26 January 1985; "Lowzow vrakes," Adresseavisen, 29 January 1985; "Kreftene Holdt ikke," Dagbladet, I2 February 1985; "Forlater Høyre i homo-protest," Dagbladet, 26 March 1985 .

58 "Partnerskapsloven: Høyre kan bidra til flertall," Aftenposten, 22 October 1992.

59 "H for homofil," Dagbladet, 2r January 200r; "Ny Høyre-politiker står fram som homse Ut av skapet," Dagbladet, I9 January 2002; "Homofili - en privatsak?" Dagbladet, 29 June 2002.

6o Voting Charts: Votering 978, 7 June 1994, I5:49. Ärende LU28, Moment r. RB.

6I Interview Hiltunen.

62 Einarsdóttir 2008, I3I-I34; Interview Gísladóttir.

63 Rydström 2007a.

64 According to Barbro Westerholm, MP Jerzy Einhorn from the Swedish Christian Democratic Party would have liked to vote in favour of the law proposal for registered partnership. Einhorn (1925-2000), who was Jewish, joined the Christian Democratic Par- 
ty because it had become a secular party based on Christian morals and traditional family politics, convictions that Einhorn shared. The fact that he shared his bench in the Riksdag with openly gay Kent Carlsson made him even more inclined to endorse the law, according to Westerholm, whereas others have suggested that it was the fact that his daughter Lena was already then an openly lesbian public figure in Sweden. Isaksson and Lennerhed (eds.) 2007. Whatever the reason, Einhorn was absent from the final vote on the law. Voting Charts: Votering 978, 7 June 1994, 15:49. Ärende LU28, Moment I. RB.

65 "for da fikk du parkert hele den der kristne siden, de bare slåss om det, hele tiden." Interview Øie and Sørensen. "Står åpent frem som homofil," Aftenposten, I8 October 1992; "Sjokk og vantro i KrF," Verdens Gang, I8 October I992; "Kan ikke ha kjæreste?” Arbeiderbladet, I9 October I992; "Ungdomspolitikerne slår ring om Gåsland," Dagbladet, I9 October 1992: "Homse-sjokket: Bondevik bedriver dyneløfting," Dagbladet, I9 October 1992. 66 "Slottner KDU-bas efter rysarval," Dagens Nyheter, 22 May 2004; "Fem frågor till Erik Slottner," Expressen, 22 May 2004.

67 Green was sentenced to one month in prison by the local District Court, a verdict upheld by the Appellate Court. But the Swedish Supreme Court ruled in this case that the clause on the freedom of religion in the European Declaration on Human Rights had precedence over the anti-discrimination clause in the Swedish Penal Code. Swedish $\mathrm{Su}-$ preme Court Ruling B I050-05, 29 November 2005.

68 "KDU väljer värdekonservativ ordförande," Dagens Nyheter, 24 March 2005; "Strid väntas vid KDU:s riksmöte," Dagens Nyheter, 23 April 2005; "Sorgligt slut för sparkad KDUledare 'Jag har stått på dödslistor'," Expressen, 6 May 2005.

69 Arter 2008, I02-3, II5-I9.

70 Interview Frevert. “Öppen flata i Folketinget - för Dansk Folkeparti," qx.se, in November 200I; "Frevert lämnar Dansk Folkeparti," qx.se, 9 May 2007.

7I "Sverigedemokrater vinner mark på kd:s ägor," Sydsvenska Dagbladet, 3 August 2008.

72 "Oslo Høyre nominerer: 'Statsrådparti' velger stemmesankere," Aftenposten, 26 January 1985; "Lowzow vrakes - Skyldes min homofili, sier hun," Adresseavisen, 29 January 1985; "Lunde seiret," Dagbladet, I2 February I985; "Lowzow, vraket," Dagen, I3 February I985.

73 During the interview, Jensrud himself said that it was not because he challenged the party group's majority that he could not stay in the Storting. It was because Thorbjørn Jagland had become party leader and needed a seat. But he admits that his situation was difficult the first time after he had presented the bill. Shortly after, Jensrud was "scandalised" in connection with a camp for young Social Democrats, when they had a dating game that included same-sex dating. Even though this was fairly innocent, the liberal newspaper Dagbladet chose to depict it as a moral outrage. Interview Jensrud.

74 “Jag trodde faktiskt att vi kommit längre än så," Expressen, 6 August i99r; ”De gör homosexuella rumsrena i politiken," Expressen, 7 August i991; “Topp-politiker: Jag är homosexuell," Expressen, 28 March 1995; "En man kommer fram ur skuggan: Topp-politikern om sitt liv som gay," Expressen, 30 March 1995.

75 Interview Andreasson; interview Stafilidis.

76 "Stortingsrepresentant siktet for grovt bedrageri," Dagbladet, 26 January 1996; "Historisk fest for Anders og Vidar," Dagbladet, i5 September 1996.

77 Per Kristian Foss got media attention when he registered partnership at the Norwegian Embassy in Stockholm, 4 January 2002. "Første statsråd i homofilt partnerskap," Dagbladet, I5 January 2002; "Foss får ros," Dagbladet, I5 January 2002; "Norsk minister ingår partnerskap,” Nya Dagen, 15 January 2002. Interview Jensrud; Interview Øie and Sørensen. 
78 "H for homofil," Dagbladet, 2r January 200r; "Ny Høyre-politiker står fram som homse Ut av skapet," Dagbladet, I9 January 2002; "Homofili - en privatsak?" Dagbladet, 29 June 2002.

79 "SV vil være homo-partiet," Dagbladet, I5 August 200 .

80 "hvis de to seneste sundhedsministre, ikke kun politisk, men også personligt, havde haft et andet forhold til Landsforeningen for Bøsser og Lesbiske." Juul-Jensen 1996, I3.

8I "Hvorfor da di går løs på meg, monntro der er noen som kjente bror min?” Interview Halvorsen. Cf. Halvorsen and Teigene 2004, 36-38.

82 "Jeg tror det er med meg som det er med mange andre, at jeg ikke har hatt dette så tett innpå meg. Derfor har jeg hatt både [sic] manglende kunnskap for eksempel om de kvaler som mange unge homofile fremdeles har i dette landet, ikke minst på landsbygda, hvor det faktisk gjør utslag på selvmordsstatistikken." "Meltveit Kleppa vil likestille homo- og heterofile," Dagbladet, 2 February 2008; cf. Seehuus 2009, I2.

83 "Islänningar är så vana vid storfamiljer. Och jag tror att vi fick dem till att förstå att vi också tillhörde den stora isländska familjen. Och att vi hade familjer och att vi var vänliga vanliga människor." Interview Eddudóttir.

84 An illustration of the differences between Iceland and the Faroes is that the leader of the Faroese Centre Party, Jenis av Rana, refused to participate in the dinner in honour of Iceland's Prime Minister Jóhanna Sigurðardóttir when she visited Iceland in September 20Iо. "Rok um ein døgurða," Dimmalatting, 7 September 20Iо; "Jenis ætti að skammast sím," mbl.is, 7 September 2010.

85 "Jag tror att Kent bidrog ganska mycket. Att han hade en stark position, han var en färgstark företrädare för partiet och alla tyckte om honom och så. Så att jag tror att han hade i upploppet - och jag kan tänka mig också på partikongresserna - en stor roll. Men sen hann han ju dö, innan ... Så att det blev på något vis a tribute to Kent.” Interview Lööw.

86 Lundberg 2003; Riksdagen Protokoll 1993/94: г20.

87 Melby et al. (eds.) 2000; Melby et al. 2006; Bradley 1996.

88 Lützen 1998,239

\section{Notes chapter 4}

I “I. oktober - et skæbnedøgn - en dødsdom! Vi danskere og ikke mindst vi kristne har underskrevet vor egen dødsdom! ... Så langt ude i suppedasen er vi danskere, at andre lande nu må se på os; som det mest besmittede af synd værende land i verden!" 'I. oktober - en dødsdom," Thisted Dagblad, I October I989; cf. "Skøgekirke," Vejle Amts Folkeblad, I8 October 1989; "Kalder I. oktober for en 'Sodomadag'," Kristeligt Dagblad, 30 September 1989; "Skammens dag," Amtsavisen Randers, I2 October 1989.

2 “Næppe folkeafstemning om partnerskab," Kristelig Dagblad, 27 May 1989; cf. "Folkekirken dybt splittet," Politiken, 2 October 1989.

3 "Borgmester nægter at vie bøsser," Politiken, I2 January 1990. "Her er ingen vaklen heller ikke i Folketinget (- Q selvfølgelig). En lov er en lov, og den skal kunne håndhæves alle steder. Poul Hansen er i denne sag lidt til grin selv, men det er han i en del sammenhænge." (The official election code of the Danish Christian Democrats is Q.) Letter from Pia Gjellerup to Bent Hansen, 22 January 1990. Vallensbæk kommunes vægring ved at foretage registreret partnerskab i990. Enkeltsager 1969-1983. Hovedbestyrelsen I.o.Ir. LBL Archive. 
4 "enhed med en reproduktiv egenskab" Letter from Else Slange to Danmarks Statistik, I9 December 1990. Sag vedr. Danmarks Statistiks opgørelsen af registrerede partnere 1989I992. Enkeltsager 1969-I983. Hovedbestyrelsen I.o.II. LBL Archive.

5 Letter from Statistics Denmark (Lene Skotte) to LBL, I5 January 1992; letter from Statistics Denmark (Henning Christiansen) to LBL, 25 March 1993. Sag vedr. Danmarks Statistiks opgørelsen af registrerede partnere 1989-1992. Enkeltsager 1969-I983. Hovedbestyrelsen r.o.Ir. LBL Archive; Interview Christiansen and Qvist. In Norway, in 1993, the routines were clear from the beginning, perhaps as a result of the discussions in Denmark. See "Registrerte partnere behandles som ektefeller," Skattebladet: Utgitt av skattedirektoratet, No. 7 (1993).

6 "[A]lle tabeller der havde med civilstand og æoteskabelig stilling skulle så udvides fra fire, tror jeg, til syv kolonner, og den gang var EDB ikke så let at ha' at gøre med som det er i dag, så vi tænkte nok lidt at, det var for stort et arbejde forbundet med det, at det var så lille"... "Vi var jo noget famlende overfor det. Det var noget helt nyt. Skulle vi betragte dem som ægtepar eller skulle vi ... Så vi startede jo med at ... klassificere dem som ugifte. Det kunne de ikke lide." Interview Christiansen and Qvist.

7 "Ref. af tlf.smtl." Internal memorandum by Dorthe Jacobsen, 15 October 1990. Sag vedr. pensionskassers vedtægtsændringer som konsekvens af registreret partnerskabs indførelse 1989-9r. Hovedbestyrelsen 1.o.Ir. LBL Archive.

8 "Bestemmelser i dansk lovgivning, der indeholder særlige regler om den ene part i et ægteskab bestemt ved køn, finder ikke anvendelse på det registrerede partnerskab.” Lov nr. 372 af 7 . juni 1989 om registreret partnerskab, $\S_{4}$, stk 3 .

9 “Ref. af tlf.smtl.” Internal memorandum by Dorthe Jacobsen, 15 October I990. Sag vedr. pensionskassers vedtægtsændringer som konsekvens af registreret partnerskabs indførelse 1989-9r. Hovedbestyrelsen 1.0.Ir. LBL Archive.

Io "Til Forretningsudvalget. Angår Pensionskasser." Internal memorandum to the Business Committee of the LBL from Dorthe Jakobsen, I8 September 1990. Sag vedr. pensionskassers vedtægtsændringer som konsekvens af registreret partnerskabs indførelse $1989-$ 91. Hovedbestyrelsen 1.o.II. LBL Archive.

II “Til Retsudvalget." Draft letter 1990; Fax to Torben Lund, 23 October 1990; Fax to Dorte Bennedsen, 23 October 1990. Sag vedr. pensionskassers vedtægtsændringer som konsekvens af registreret partnerskabs indførelse i989-9r. Hovedbestyrelsen r.o.Ir. LBL Archive.

I2 "Registrerede partnere diskrimineres: Klager over DSB-praksis," Politiken 23 April I99I; "Bøsser og lesbiske gratis med DSB," Ekstra Bladet, 28 March 199I; "Ingen rabat til bøsser," Ekstra Bladet, 8 June 1994.

I3 "Det bekræfter en opfattelse hos danskerne at vi kan godt være ordentlige ... Altså vi elsker jo også historien om at jøderne blev reddet i Danmark ... Det er den gode historie. $\mathrm{Og}$ alle nationer har sine gode historier. Og den der vil komme til at stå på udstillingshylden af det vi en gang vil sige, det er den gode historie fra den sidste del af det tyvende århundrede. Det er fint. På den måde så har små lande en mulighed for at gøre en stor ting." Interview Gjellerup.

I4 In Norway, the South and West are known to harbour traditionalist Christians to a larger degree than other areas of the country. The North and inland, on the other hand, are considered liberal, and it was in the diocese of Hamar, bordering on Sweden, that the first female bishop was ordained. Hamar's diocese also employed the first lesbian priest living in registered partnership. Personal communication with Hans W. Kristiansen, 26 October 2009 . 
I5 Stortingets Forhandlinger 1992-93. Dokument nr. 8:27 for 1992-93; Innst. S. nr. I98, Forhandlinger 3. juni 1993, pp. 4I35-4I36. Cf. "Bør få nekte å 'vie' homofile.' Partnerskapsloven i realiteten ekteskap, mener Bjørn Bue,” Rogalands Avis, I5 July 1993.

I6 Stortingets Forhandlinger 1995-96. Dok. nr. 8:Io6. Stortingets Forhandlinger 1996-97. Meeting I7 December 1995, p. 367-69, 373 .

I7 "Skred av utmeldelser etter homofili-striden," God Helg/Varrt Land, 9 February 1996; "Homosaken truer Kirkemøte-idyllen," Aftenposten, 7 November 1997.

I8 “Homosexuella par - titta hit!" Mölndals-Posten, 7 December 1994.

I9 "Glöm inte, att äktenskapet är en helig handling - även vid en borgerlig vigsel." "De vägrar viga homosexuella," Nordvästra Skånes Tidningar, 23 December 1994.

20 "Var tredje kommun saknar partnerskapsförrättare," TT Telegramme no. 950207I404NNN, 7 February 1995; "Inga partnerskap i Robertsfors," Västerbottens-Kuriren, 5 January 1995; "Henningsson vägrar viga homosexuella," Skövde Nyheter, 5 January I995; "Vigselförrättare vil inte viga homosexuella par," Sala Allehanda, 5 January I995; "”Vigsel med förhinder," Upsala Nya Tidning, 5 January 1995; "Gnestapolitiker vägrar viga homosexuella: 'Det är emot naturen'," Södermanlands Nyheter, 5 january 1995; "Homosexuella kan inte gifta sig i Håbo," Enköpings-Posten, 5 January I995; "Hon vägrar viga homosexuella," Borås Tidning, 5 January 1995; "Partnerskap får vänta: Sex kommunner i Malmöhus län saknar just nu förrättare för registrering, Arbetet, 5 January 1995; "Homosexuella par strider mot naturen: Vigselförrättare vägrar registrera partnerskap," Folket, 5 January 1995; "RFSL kräver besked av vigselförrättarna," Nya Norrland, 3 February 1995; "Vägrar 'viga' homosexuella," Norra Skåne, 27 January 1995; "Vigselförrrättare i AC-län negativa till partnerskap," Norra Västerbotten, 24 January 1995; "Kävlinge: Ingen vill viga homosexuella," Sydsvenska Dagbladet, 24 January 1995; "Homosexuella vägras 'vigsel'," Svenska Dagbladet, 20 January 1995; "De vägrar att "viga' homosexuella par," Norrländska Social-Demokraten, I2 January I995; "Vigselförrättaren som vägrar viga: 'Homosexuella äcklar mig'," Arbetaren, no. 4 (I995); "Homosexuella vägras vigselbild," Svenska Dagbladet, ${ }_{25}$ February 1995; "Egon Frid är redo viga homosexuella," Skaraborgs Läns Allehanda, 25 February 1995; "Bertil Lundberg viger nu även homosexuella," Västernorrlands Allehanda i8 February 1995; "Klart för homosex-partners även här!" Fagersta-Posten, I3 February 1995.

2I "Finns det kärlek i Robertsfors?” Västerbottens-Kuriren, I2 January I995; "Har ni rätt att döma?" Oskarshamns-Tidningen, I2 January I995; "Nya lagen ett hafsverk," Sydsvenska Dagbladet 29 January 1995; "Partnerskapslagen inget hafsverk," Sydsvenska Dagbladet, 13 February I995; "Illvilja mot homosexuella," Östgöta Correspondenten, 8 February I995; "Fundamentalister på hemmaplan," Bohuslänningen med Dals Dagblad, 8 February 1995; "Värna ny lag," Göteborgs-Posten, 2I January 1995.

22 "S-politiker vägrar 'viga' homosexuella," Helsingborgs Dagblad, 3I March I995; “- Uteslut Törnlycke! Angrepp från s-studenter mot partikamrater som inte vill förrätta partnerskap,” Arbetet, 27 January 1995; “Av sossar bör krävas anständighet," Aktuellt i politiken, no. Iо (1995).

23 "Ingårda ny CUF-ordförande," Folket, 3 March 1995; "Kräver vigselförrättares avgång," Södermanlands Nyheter, 3I May 1995.

24 "Det var hårt då, hårda inre förhandlingar. Vissa, framförallt bland de äldre, var ganska oresonliga mot mig." "Grattis! Blev du ombedd att ta jobbet?” Expressen, ${ }_{5}$ December 1997. 25 "Borgerliga förrättare får inte vägra viga homosexuella," Magazinet, 26 May 200o; "Lars och Lars vill gifta sig i kyrkan," Dagens Nyheter, 3І December 2003; "Kyrklig välsignelse välkomnas: Lesbiskt par hoppas kyrkomötet i dag ska säga ja till ny ceremoni," Dagens Nyheter, 27 October 2005. 
26 Two parents raising a child were automatically regarded as custodians. If a biological parent was no longer part of the household, he or she also counted as parent. Thus a child could have three legal parents. SOU 200I:I0, I85-6; "Samkynhneigðir og ættleiðingar barna," Vikublaðið, I5 November 1996; Lög 52/2000 um breytingu á lögum um staðfesta samvist 8. mai 2000.

27 "er partur af sköpunarverkinu og par af leiðandi hlýtur hún að vera Guðs vilji." Ólafur Stephensen, "Kirkjan og samkynhneigð," Lesbók Morgunblaðsins, 4 September 1999.

28 "Flestir prestar landsins svo og kirkjuleg yfirvöld láta slika gagnrýni oftast sem vind om eyru pjóta, svara engu, alger pögn, pví að engan styggja! . . Kristin kirkja mun aldrei fordæma neinn fyrir pann sjúkdóm sem hann gengur með." Ragnar Fjalar Lárusson, "Kirkjan og samkynhneigð," Morgunbladið, I4 September 1999.

29 Hrafnkell Tjörvi Stefánsson, "Fáfræði og fordómar," Morgunblađið, I8 September 1999; Ragnar Fjalar Lárusson, "Fallinn engill,” Morgunbladið, 21 September 1999; Haukur F. Hannesson, "Jörðin er flöt," Morgunblađið, 24 September 1999; Pórður Sigurðsson, "Hverjir eru kúgaðir?” Morgunblađid, 25 September 1999; Roald Eyvindsson, "Hinsegin kirkja," Morgunblađið, 29 September 1999; Fanny Kristín Tryggvadóttir, "Samkynhneigð og tjáningarfrelsi," Morgunblaðið, 30 September 1999; Hjalti Hugason, “Kirkja og samkynhneigð,” DV, 30 September 1999; Sigrún Ármanns Reynisdóttir, “Með kærleikann að leiðarljósi,” Morgunblaðið, I October 1999; Jóhann Björnsson, "Krossfarar kærleikans," Morgunbladid, 4 October I999; Auður Eir Vilhjálmsdóttir et al., "Um kynhneigð fólks," Morgunblaðið, 5 October I999; Guðni Baldursson and Lana Kolbrún Eddudóttir, "Sjúkir, sekir og syndugir," Morgunbladið, 5 October 1999; Örn Bárður Jónsson, "Samkvæmt og gagnkvæmt umburðarlyndi," DV, 6 October 1999; Magnús Sigmundsson, "Er samkynhneigð kristileg?” Morgunbladið, 7 October 1999; Stefán Guðjónsson, "Pjóðkirkjan á réttri braut," Morgunbladið, 7 October 1999; Bergpór Pálsson, "Blómin á akri tilverunnar," Morgunbladid, 7 October 1999; Steingrimur Ómar Lúðvíksson, “Lækning fyrir samkynhneigða,” Morgunblaðið, 7 October 1999.

30 During a stay in Greenland in September 2005, I asked for confirmation of the number of partnership registrations performed by the Mayor of Nuuk, but she declined to give me that information for the sake of the anonymity of those concerned. I did not ask for the names of those who had registered partnership, but the Mayor nevertheless thought the information was too sensitive to hand out.

3I "Akuersaarneqannginneq artornartorujussuuvoq / Svært når homoseksuelle ikke bliver accepteret," Atuagagdliutit / Grønlandsposten, 22 July 2004. Interview Jørgensen and Mølgaard.

32 Interview Olsen; "Angutinoortartut arnanoortartullu nunatsinni peqatigiiffiat siulleq / Grønlands første forening for bøsser og lesbiske," Atuagagdliutut / Grønlandsposten, 22 February 2002.

33 "Utredning om adoptionsrätt för homo- och lesbopar," Borgåbladet, 3 May 2002. There was an agreement within the Government that the Ministers and MPs from the Green Alliance would vote for the proposal only if the Government immediately appointed a commission to investigate all parenthood issues in connection with the law on registered partnership. Personal communication Kati Mustola, February 2010.

34 "Registrerat partnerskap hinder för kyrkliga jobb?” Österbottningen, 5 April 2002; "Kirkko pohtii tavallista visaisempia kysymyksiä," Helsingin Sanomat, I2 May 2002; "Kyrkomötet fortsatte diskutera partnerskapslagen," Österbottningen, I6 May 2002; "Kirkko haluaa vaaleihin homoehdokkaita," Etelä-Suomen Sanomat, I7 May 2002; "Kyrkan och de homosexuella," Hufoudstadsbladet, I8 May 2002. 
35 "Enemmistö suomalaisista vastustaa homoliittojen kirkollista siunaamista," Sanansaattaja No. 20 (2002); "Nej till kyrklig välsignelse av homosexuella," Kyrkpressen, No. 20 (2002); "Riekkinen redo att välsigna homopar," Österbottningen, 23 April 2002; "Fallet Riekkinen går vidare," Kyrkpressen, No. 35 (2002).

36 "Koskinen: Kirkonkin pitää noudattaa parisuhdelakia," Helsingin Sanomat, I5 April 2002; "Oikeusministeri vaarallisella tiellä," Hyvinkään Sanomat, I7 May 2002; "Homosexuellt parförhållande kan motivera anställningsstopp," Kyrkpressen, No. 24 (2002).

37 "Ett betänkande att betänka," Kyrkpressen, No. 4I (2003); "Ortodoxa kyrkan har inte gett riktlinjer," Hufuudstadsbladet, I4 December 2007.

38 "Finlandssvenskar sade sin åsikt: Österbottningar för pälsfarmer, mot homoadoptioner," Vasabladet, 22 May 2002; "Homoparien adoptio-oikeus tuottaisi lapsille vaikeuksia," Pohjalainen, 26 July 2002; Britt Lundberg, "Därför nej till homoadoption," Nya Åland, II March 2003; Bengt Ahlfors, "Rätt att adoptera," Hufoudstadsbladet, 3 May 2003; "Centern avgör adoptionsfrågan," Hufvudstadsbladet, 9 September 2003; "Homoille sisäinen adoptio-oikeus," Hufvudstadsbladet, 8 September 2003; Asmo Maanselkä, "Homoparien adoptio-oikeus ei ole lapsen oikeus," Keskisuomalainen, 6 September 2003.

39 "Nuorten ehdokkaiden tavoitteissa painottuvat arvokysymykset," Länsiväylä, 9 March 2003; "Parisuhteensa rekisteröineille ehdotetaan adoptio-oikeutta," Kotimaa, No. 37 (2003); “'Homopar måste få adoptera.' Fsud: Det är en jämlikhetsfråga," Jakobstads tidning, I5 November 2003; "Homopar bör få adoptera: Ingen diskussion om fsud:s motion," Jakobstads tidning, I7 November 2003.

40 "Nu diskuteras assisterad befruktning," Syd-Österbotten, 25 June 2002; "Hedelmöityshoitolaki takaa jokaiselle lapselle isän," Itä-Savo, I7 June 2002; "Oys ei halua hedelmöittää naispareja tai sinkkuja," Kaleva, II June 2002; "Fertilitetsbehandling svår fråga för riksdagen," Vasabladet, II June 2002; "Donator kan inte fă förbli anonym," Hufvudstadsbladet, I9 December 2002.

4I "Parliament votes to allow fertility treatment for single women and lesbian couples: Decision comes after years of delays," Helsingin Sanomat International Edition I3 October 2006. www.hs.fi/english. Viewed 24 October 2006; Laki hedelmöityshoidoista 22.I2.2006/I237 / Lag om assisterad befruktning 22.I2.2006/I237.

42 This new way of theorising heteronormativity had its greatest success in Iceland, Finland, Norway, and Sweden but was less enthusiastically received by Danish scholars and activists. Icelandic gay and lesbian activists have officially adapted queer theory to Icelandic, and the huge Reykjavík Gay Pride celebration is called Hinsegin dagar, or Queer Days, in Icelandic. "Queer" is translated binsegin, which means "the other way". In I999, gay activist Haukur Hannesson suggested that it should be translated with the old derogatory term kynvilla. It was the word for homosexuality, literally meaning "sex-confused" that the movement had strived to eradicate from the Icelandic vocabulary, and his proposal never caught on. Hannesson 1999.

43 Swedish historian Svante Norrhem has discussed the silence that surrounded same-sex practices in Swedish rural areas, and how homosexuality was thought of as something they did elsewhere, in cities. Norrhem $200 \mathrm{I}$.

44 Interview Anders and Folke. For a discussion of heteronormativity in the Church of Sweden, see Lindström 2005 . 


\section{Notes chapter 5}

I “Så fik de papir på kærligheden”, Berlingske Tidende, 2 October I989; “Tillykke," Ekstra Bladet, 2 October 1989; "Tillykke," Politiken, 2 October 1989; "Homoseksuelle til bunkebryllup i går," 2 October 1989; "Danmark har skrivit världshistoria: Axel och Eigil gifta," Sydsvenska Dagbladet, 2 October 1989; "Historisk vigsel i Köpenhamn," Dagen, 3 October I989.

2 "de var bange for offentligheden" "Ringe interesse for ny lov: Lesbiske vil ikke indgå ægteskab," B. T., I2 October I989; "Partnerskab appellerer ikke til de lesbiske," Berlingske Tidende, II January 1990. For a similar reaction in the Swedish press, see "Partnerskap en flopp - fyra par på fem år," Västerbottens Folkblad, I4 February 2000.

3 Interview Slange.

4 In Denmark and Norway, where the law became effective on October I and August I, respectively, this was the case for the first two years.

5 Andersson et al. 2006, 88.

6 Andersson et al. 2006, 95-96.

7 Andersson et al. 2006; Eskridge and Spedale 2006; Varnell 2006.

8 Badgett 2009, 45-63.

9 Andersson 2006.

Io Hirschfeld I904.

II Laumann et al. 1994, 294 .

I2 In Finland, another ratio is often used. Referring to the Kinsey report, where it says that 4 percent "are exclusively homosexual throughout their lives after the onset of adolescence" (Kinsey 1948, 651), Finnish lesbian and gay activists claim that homosexuals are 4 percent of the Finnish population, and compare it to Swedish speakers who are 5-6 percent. As the Swedish speakers enjoy far-reaching minority rights, it is convenient to compare them with the homosexual part of the population. Personal communication with Kati Mustola.

I3 Emphasis in original. The expression "rate 5 or 6" referred to Kinsey's scale from o to 6 according to which o represented exclusively heterosexual and 6 exclusively homosexual desire or practice. Kinsey et al. 1948, 651.

I4 Kinsey et al. 1953, 473-74.

I5 Laumann et al. 1994, 289; Jones I997.

I6 Sedgwick 1990; Rupp 200I; Altman 200r; Puar 2007.

I7 Dover 1989; Lund 2006; Herdt (ed.) I994; Boswell I980; Kuefler (ed.) 2006; Lever 1985; Dinshaw I999.

I8 Like registered partnership in the Netherlands, the German Eingetragene Lebenspartnerschaft and the French Pacte Civil de Solidarité (Pacs) are open to different-sex and samesex couples alike, and in 2008, 94 percent of the pacs in France were made by different-sex couples. "Le pacs s'est imposé dans le paysage nuptial français," Le Monde, Io November 2009. For a long time, it was impossible to obtain statistics based on the sex of the "pacsés," but when data is available it reveals a huge interest in it from heterosexual citizens. Digoix and Festy 2004; Festy 2001; Martin and Théry 200r; Fassin 2005.

I9 Waaldijk 20or.

20 One unforeseen effect of the new law is that Norwegian and Swedish embassies abroad can no longer perform partnership registrations. Only in the countries which have laws on gender-neutral marriage can the embassies perform a marriage for same-sex couples. "Claes och Håkan nekades gifta sig i Paris," qx.se, 3 December 2009. 
2I Schalow 1993; Murray and Roscoe (eds.) I998; Chou 2000; Wu 2002; Sang 2003; ElRouayheb 2005; Wong 2005; Brickell 2008.

22 Herdt (ed.) I994; Nanda 1999; Penrose 200I; Wallace 2003; Vanita and Kidwai (eds.) 200I, Altman 2002.

23 Kinsey et al. 1948; Kinsey et al. 1953.

24 Chenier 2008; Söderström 1999, 5 I2.

25 Esping-Andersen 1990; Åmark 2005; Christiansen and Petersen (eds.) 2001.

26 Zetterqvist Nelson 200r; Ryan-Flood 2009; Hammack and Cohler (eds.) 2009.

27 The concept of queer feminism has been especially successful in Sweden, as it has been adopted by, for example, the Environment Party, the Left Party, and the Feminist Initiative, but it has also had an important impact in Norway and Finland, as well as in some leftist circles in Denmark. Rosenberg 2002; Kulick 2005.

28 Robinson 2005; Duggan 2004b; Duggan and Kim 2005; Warner 1999; Edelman 2004.

29 "Barnet, naturligtvis. Det känns tryggare om vi har det på papper. För Sanna handlar det nog också om att göra det för att vi kan. Hon tycker att man ska utnyttja den lag som i alla fall finns och inte grubbla alltför mycket på vad som inte finns än.” Adeniji 2008, 284. 30 Only one of twenty interviewees self-identified as lesbian, and only four of them had children. Of those with children, one identified herself as heterosexual, one as bisexual, and two did not want to specify their sexuality. Adeniji 2008, 337-9.

3I "historia som lesbisk ... När jag som I9-åring kom ut i början av 9o-talet såg livet som lesbisk mycket annorlunda ut än vad det gör idag. Till min självförståelse som nyutkommen lesbian hörde exempelvis att jag aldrig skulle komma att få barn, eftersom jag var lesbisk. Inte heller skulle jag kunna gifta mig. Under $1990-$ och $2000-t a l e n$ har det stiftats nya lagar (till exempel rörande partnerskap och insemination) som samspelat med min lesbiska identitet och omstrukturerat min självförståelse." Hallgren 2008, 63, n.Io.

32 Ryan-Flood 2005; Jones 2005; Stacey 2006; Söderström-Anttila et al. 2002.

33 "så var det ju förr ... man valde ju bort det om man valde att leva ut sin läggning då ... så valde man ofta bort barn." "Ja först det här med partnerskap det hade kommit ... och det var Eva som liksom synliggjorde oss." Zetterqvist Nelson 2007, 4I.

34 For an overview of the history of the Scandinavian welfare systems, see Christiansen et al. (eds.) 2006; Åmark 2005.

\section{Notes chapter 6}

I “justering af partnerskabsloven.” "Næste skridt bliver kirken,” Politiken, I9 May I993.

2 "Några undrar om inte detta bara är det första steget. Sedan kommer adoption, gemensam vårdnad och insemination. Det har rests krav också kring dessa frågor. Jag kan bara svara för mig och för det socialdemokratiska partiet. Detta är steget. Det är inte det första steget." Riksdagen 1993-94. Protokoll 1993/94:I19, 7 June 1994, § 4, Anf. 8.

3 Interview Lööw.

4 Lov nr. 82I af I9. december 1989 om ændring af lov om registreret partnerskab; Lov nr. 387 af I4 juni I995 om forældremynighed og samvær; Lov nr. 460 af ıo. juni 1997 om kunstig befrugtning i forening med lægellig behandling, diagnostik og forskning, mv.

5 "Homopagt og indvandring," Berlingske Tidende, 2 September 1989; Interview Lund.

6 Lov nr. 360 af 2. juni 1999 om ændring af lov om registreret partnerskab.

7 Lag (2000:374) om ändring i lagen (I994:III7) om registrerat partnerskap. 
8 Scappucci 2000; Bell 200r; European Court of Justice: Joint Cases C-I22/99 P, C-I25/99 P. Quoted from Wintemute and Andenæs 200I, 654, n.3.

9 Nytt Juridiskt Arkiv 1955, p. 63. Moreover, homosexuals and bisexuals always have had the possibility of adopting children as individuals. One such example is the Swedish singer and actor Karl Gerhard (1891-1964), who was married three times and had a son in his second marriage. From the I950s he lived with his secretary Göthe Ericsson and together they adopted and raised a daughter who also became a singer (Ahlgren i966; Pettersson 1977; Rosell 200I). Examples of famous lesbian child-raisers are Nobel laureate Selma Lagerlöf, who adopted a boy by the name of Nils Holgersson - the name of her most famous character (Edström 2002; Ulvros 200I) - and journalist Barbro Alfving, who published a long series of chronicles in the Swedish press during the I950s and I96os about her life with her life companion "Vivan" and her child "The Kid" (Ungen) whom she and Vivan raised (Cantera Carlomagno [ed.] 200r; Alving and Alving-Olin 2009).

Io For the use of the term "breeder" for homosexuals, see the definition at Slangsite.com, http://www.slangsite.com/slang/B.html. Viewed 9 May 20I0. D’Emilio I983; Rydström 2007c; Storr (ed.) I999.

II Anderssen et al. 2002; Halldén et al. 2003; Zetterqvist Nelson 200I, 2006, 2007; Stacey 1996, 2006.

I2 Dunne 2000; Flaks et al. 1995; Gabb 2005; Patterson 1995; Ryan-Flood 2005.

I3 Lov nr. 387 af I4. juni I995, Lov om forældremyndighed og samvær, § 36, was replaced by Lov nr. 499 af 6 juni 2007, Forældreansvarslov, I October 2007. The current law does not contain the same restriction.

I4 Lov nr. 460 af Io. juni 1997 om kunstig befrugtning i forbindelse med lægelig behandling, diagnostik og forskning mv. A paragraph was added to the law proposal, stating that "assisted fertility treatment can only be offered to women who are married or living with a man in a marriage-like relationship." For the history of Nina Stork's clinic, see its home page on http://www.storkklinik.dk/ (accessed 2 September 2008); Albæk 1998; Lützen 2000; Bryld 200I.

I5 Lov nr. 360 af 2. juni 1999 om ændring af lov om registreret partnerskab; Icelandic Law no. 52 of 8 May 2000; Norwegian Law no. 36 of 15 June 200 (in force I January 2002 according to Royal Decree no. 6I2 of 15 June 200I).

I6 Inatsisartut/Landstinget. Efterårssamling 2008. Fortryk I October 2009; Fortryk 5 November 2009. http://cms.inatsisartut.gl/samlingerhome/tidligere-samlinger.aspx

I7 Perheen sisäinen adoptio rekisteröidyn parin perheessä 2008; "Regnbågspar får adoptionsrätt," Hufvudstadsbladet, I5 May 2009; "Regnbågsfamiljer äntligen lagliga i Finland," www. qx.se, I September 2009.

I8 SOU 2001:I0; Riksdagen 200I-02. Proposition 200I/O2:I23; bet. 2001/02:LU27, "Partnerskap och adoption"; Protokoll 200I/O2:I2O, 5 June 2002; Swedish Law (2002:603) amending the Law (I994:III7) on registered partnership; Zetterqvist Nelson 200I, 2006, 2007; Halldén et al. 2003. Full adoption rights now exist in Sweden, Iceland (since 2006), Denmark (since 2009), and Norway (since the introduction of the gender-neutral marriage law in 2009).

I9 Lög Nr. 65, I4. júní 2006 um breytingu á lagaákvæðum er varða réttarstöðu samkynhneigðra (sambúð, ættleiðingar, tæknifrjóvgun); "Homoseksuelle jubler over flere bleskift," Politiken, I7 April 2009; "Uenighed i Venstre sikrer homoseksuelle adoption," Politiken, I8 April 2009. Folketinget. Møde nr.86, Tuesday 4 May 2010. 
20 Norwegian Law No. 53 of 27 June 2008 amending the marriage law, the child law, the adoption law, the law on biotechnology, etc. The mutual marriage law for heterosexual and homosexual couples became effective I January 2009.

2I At the same elections, however, the right-wing populist and homophobic party "The True Finns" increased from 0.5 to 9.8 percent of the votes. "Det här är rena självmordet för SFP. Nu kan finnarna kalla oss för homopartiet." Carl Gustaf Aminoff to Hufvudstadsbladet, I7 May 2009. Election results published in Hufoudstadsbladet, 9 June 2009.

22 Icelandic Law No. 65 of I4 June 2006 amending laws concerning homosexuals' rights (cohabitation, adoption, assisted reproduction) [Lög Nr. 65, I4. júní 2006 um breytingu á lagaákvæðum er varða réttarstöðu samkynhneigðra (sambúð, ættleiðingar, tæknifrjóvgun)]; Alpingi 2007-2008. Pskj. I8 - I8. mál. Law proposal amending various laws concerning homosexuals' rights. [Frumvarp til laga um breyting á ýmsum lagaákvæðum sem varða réttindi samkynhneigðra]; Minutes of the debate I2 November 2007. Traustadóttir and Kristinsson 2009.

23 Skýrsla 2004; Icelandic Law No. 55 of 7 June 2008, amending the Law No. 87/1996 on registered partnership with subsequent amendments [Lög nr. 55, 7. júní 2008 um breytingu á lögum um staðfesta samvist, nr. 87/1996, með síðari breytingum]; Traustadóttir and Kristinsson 2009.

24 Alpingi 2008. Frumvarp til laga um breytingar á lögum um staðfesta samvist, nr. 87/1996; Frumvarp til laga um breyting á ýmsum lagaákvæðum sem varða réttindi samkynhneigðra. Pskj. I8 - I8. mál, quoted from Traustadóttir and Kristinsson 2009, 278.

25 Eduskunta 2002. LA 79/2002 vp / LM 79/2002 rd; HE 76/2002 vp / RP 76/2002 rd.

26 Eduskunta 2006. HE 3/2006 vp / RP 3/2006 rd; LaVM I2/2006 vp / LaUB I2/2006 rd; PTK Io7/2006 vp / PR I07/2006 rd; Laki hedelmöityshoidoista 22.12.2006/1237 / Lag om assisterad befruktning 22.I2.2006/I237.

27 Arter 2008.

28 Folketinget 2003-2004, beslutningsforslag Bi69; Folketinget 2004-2005 (I. samling), beslutningsforslag B 7, lovforslag L I33; Folketinget 2004-2005 (2. samling), lovforslag L I30; Folketinget 2005-2006, lovforslag L 228.

29 Folketinget 2003-2004, beslutningsforslag B I6r; Folketinget 2004-2005 (2. samling), lovforslag L I50; Folketinget 2005-2006, beslutningsforslag B 60; Folketinget 2007-2008 (2. samling), beslutningsforslag B I22.

30 Folketinget 2008-2009 (2. samling). L 67 Forslag om ændring af lov om ægteskabs indgåelse og opløsning og forskellige andre love samt ophævelse af lov om registreret partnerskab.

3I Lene Espersen. Folketinget 2007-2008 (2. samling), 5Ist Meeting, 9 April 2008, I:00 p.m.

32 Simon Emil Ammitzbøll. Folketinget 2007-2008 (2. samling), 5Ist Meeting, 9 April 2008, i:oo p.m.

33 Folketinget 2007-2008 (2. samling), 51st Meeting, 9 April 2008, or.oo p.m.

34 Folketinget 2008-2009. 66th Meeting, I7 March 2009, I:00 p.m. Folketinget 2008-2009. $\mathrm{B} 36$ Forslag til folketingsbeslutning om adgang til at ansøge om fremmedadoption for par i registreret partnerskab. "Uenighed i Venstre sikrer homoseksuelle adoption," Politiken, I7 March 2009; "Homoseksuelle jubler over flere bleskift," Politiken, I7 March 2009; "Rasende DF'ere føler sig ydmyget efter homolov," Politiken, I8 March 2009. Folketinget. Møde nr.86, Tuesday 4 May 2010.

35 Hegna et al. 1999, 32I-22; SOU 2000:88; SOU 200I:I0; SOU 2007:3; 2007:I7.

36 Hegna et al. 1999; "Homofile krever handlingsplan," Dagbladet, 28 February I999. 
37 "Anne fikk sin Tine Kjær," Dagbladet, I8 January 2000; "Varm støtte etter avsløringen," Dagbladet, 23 January 2000; "Tror flere gjør som Anne og Per-Kristian," Dagbladet, 23 January 2000.

38 Stortingets Forhandlinger 2000-or. Stortingsmelding nr. 25, 9 March 200r; Møte torsdag den 3r. mai $200 \mathrm{kl}$. ro.

39 "De vet godt hva norsk lov sier, og de vet godt hva de har gjort" "Valgerd beskylder Anne Holt og Tine Kjær for ulovlig befruktning," Dagbladet, Io July 2002; "Jeg oppfatter ditt angrep på meg som gravid kvinne som ukristelig og hatefullt ... Jeg håper at dine uttalelser, der du insinuerer at min graviditet er ulovlig, var en ren lapsus. I alle fall forventer jeg en uforbeholden unnskyldning." "Tine Kjærs brev til Valgerd Svarstad Haugland," Dagbladet, II July 2002; ”Trøster Valgerd," Dagbladet, I7 July 2002.

40 Stortingets Forhandlinger 2003-04. Ot.prp. nr. $\mathrm{IO}_{4}$ (2003-2003); Innst. O. nr. 52 (20032004); Odelstingets møte den 26 februar 2004; Lagtingets møte den 2 mars 2004; Lov om endringer i Lov 4 . februar $1977 \mathrm{nr} .4 \mathrm{om}$ arbeidervern og arbeidsmiljø mv. (likebehandling i arbeidslivet) m.m. Cf. Council Directive 2000/78/EC of 27 November 2000 establishing a general framework for equal treatment in employment and occupation.

4I EEA, or European Economic Area, is an agreement between the countries that are members of the European Union and Iceland, Liechtenstein, and Norway, which allows the latter three to participate in EU's single market. It also invites them to harmonise their laws with EU regulations to facilitate free trade and movement. Lov nr. 33 av den 3 juni 2005 om forbud mot diskriminering på grunn av etnisitet, religion mv. (diskrimineringsloven).

42 Plattform for regjeringssamarbeidet mellom Arbeiderpartiet, Sosialistisk Venstreparti og Senterpartiet 2005-09, Oslo 2005. http://www.regjeringen.no/nb/dep/smk/dok/rapporter_ planer/rapporter/2005/soria-moria-erklaringen.html?id $=438515$

43 Seehuus 2009, 9.

44 Stortingets Forhandlinger 2007-08. Ot.prp. nr. 33, p. 5-6.Odelstingets møte onsdag den II. juni $2008 \mathrm{kl}$. Io,

45 "Jeg er ikke stolt av alt Kristelig Folkeparti har sagt om homofile opp gjennom årene. Det er sikkert mange som er blitt såret. Det er jeg lei meg for. Samtidig må man ha respekt for at Kristelig Folkeparti, på lik linje med alle andre partier og samfunnet for øvrig, har endret syn på både homofile og deres rett til å leve i forpliktende samliv." Ibid.

46 "Alle partier i denne sal har ment noe om partnerskapsloven. De som har snudd mest, er de som i dag sier at partnerskapsloven er diskriminerende. Arbeiderpartiet sa noe helt annet da partnerskapsloven ble vedtatt." Stortingets Forhandlinger 2007-08. Odelstingets møte onsdag den Ir. juni $2008 \mathrm{kl}$. ro. Bjørg Tørresdal (KrF) [ır:30:55].

47 "Det er min overbevisning at vi gjennom denne tilpasningen til en ny tid styrker det forpliktende samliv og familien som grunnstein i vårt samfunn.... Ønsket om å bygge familiære relasjoner, en familiær setting for et liv, er for Høyre svært, svært viktig." Stortingets Forhandlinger 2007-08. Odelstingets møte onsdag den Ir. juni $2008 \mathrm{kl}$. Io. Olemic Thommessen (H) [10:44:00].

48 "Jeg husker den første ordentlig åpne homsen jeg ble kjent med. Jeg var da I7-I8 år og var i Unge Venstre, som jo alltid har hatt sin homsekvote, og jeg husker vi snakket om: Hvorfor blir det så outrert? Hvorfor blir man så annerledes? Jeg husker han sa: Når du må bryte så med samfunnet og med nettverket ditt for å kunne være den du er, er du ikke lenger forpliktet av samfunnets normer. Det var en veldig stor aha-opplevelse. / / Det vi gjør i dag, er at vi faktisk sier at vi vil at alle skal bli behandlet likt, men det vil også bety at vi skal kunne vente at fellesskapets normer skal gjelde alle. Fellesskapets normer sier at nå forventer vi at alle skal ha muligheten til å inngå forpliktende fellesskap, men da forventer 
vi også at fellesskapets normer ligger der." Stortingets Forhandlinger 2007-08. Odelstingets møte onsdag den Ir. juni 2008 kl. ro. Trine Skei Grande (V) [Ir:53:06].

49 Stortingets Forhandlinger 2007-08. Lagtingets Møte tirsdag den I7. juni 2008 kl. Io.

50 Stortingets forhandlinger 2007-08. Ot.prp. Nr. 33; Innst. O. Nr. 63; Besl. O. Nr. 91; Norwegian Law No. 53 of 27 June 2008 amending the marriage law, the child law, the adoption law, the law on biotechnology, etc. (joint marriage law for heterosexual and homosexual couples), in force I January 2009.

5I I thank Hans W. Kristensen for clarifying this for me.

52 SOU 2007:17.

53 "Sören och Daniel sa ja i Visby," www.qx.se, Ir July 2007; "Grattis Sören och Daniel," Stockholm City, 2 August 200\%.

54 "Det var ju ett arbete där många var inblandade.... Men man måste också komma ihåg att såna personer såsom Yvonne Andersson från Kristdemokraterna var ju också väldigt viktig i det här arbetet, eftersom hon karaktäriserade på något sätt motståndet, och gjorde det så väldigt tydligt varför det var viktigt.” Interview Juvas.

55 "Vi skrev en motion för socialdemokraternas kongress och bad Urban Fransson att lägga den. Eftersom han var kommunalråd ifrån Arjeplog ... Det var viktigt att det inte var en storstadsfråga. Det var ett kommunalråd som var helt öppen med sin sexuella läggning, otroligt populär inom partiet och åtnjöt ett väldigt stort förtroende i sin hemkommun." Interview Juvas.

56 "Världens första partiledardebatt om hbt-frågor," www.qx.se, 4 August 2006; "Stolthet som varumärke," Sydsvenska Dagbladet, 4 August 2006.

57 "Vi accepterade ingen annan än partiledarna och lovade att det skulle stå en tom stol på scenen för dom som inte kom. Vilket retade upp hela socialdemokratin eftersom Göran Persson vägrade komma och när han vägrade komma då kom hela Alliansen springandes.” Interview Juvas.

58 "Men valet var ju hans. Och det var ju sagt att han hade semester och det var synd om honom, vilket var dumheter ... Han ville ju helt enkelt inte." Interview Juvas.

59 Riksdagen 2008-09. Motion 2008/o9:K 374 ; Prop 2008/o9:80; Civilutskottets betänkande 2008/o9:CUi9. Cf. Motion 200I/O2:Li7, 200I/o2:Li8, 2001/o2:Li9, 2001/o2:L2O, 200I/O2:L2I, 200I/O2:L22, 200I/O2:L24, 200I/O2:L25, 200I/O2:L26, 200I/O2:L27, 200I/O2:L2I2, 200I/O2:L226, 200I/O2:L248, 200I/O2:L273, 200I/O2:L308, 2001/02:L309, 2001/O2:L314, 2001/02:L319, 2001/O2:L325, 2001/02:L327, 2001/02:L344, 2001/02:L355, 2001/O2:L357, 2001/O2:L359, 2001/O2:L368, 2001/O2:L371, 2001/02:K284, 2001/02:So495.

60 Riksdagen 2008-09. Prot. 2008/2009:95, I April 2009.

6r Lag (2009:260) om upphävande av lagen (I994:III7) om registrerat partnerskap; Förordning (2009:263) om vigsel som förrättas av särskilt förordnad vigselförrättare.

62 "Nu kan Sara och Cecilia gifta sig i Svenska kyrkan," Dagens Nyheter, 23 October 2009; "Applåder för homo-gifte," Göteborgs-Posten, 23 October 2009; cf. Lindström 2005.

63 "Frú forseti. Ég segi já með sól î hjarta. Mér finnst Ísland og heimurinn vera betri í dag en í gær.” Alpingi. I38 löggjafarping 2009-20ı0, Pskj. I256, 485. mál, ıI June 20ıo. Lög nr. 55, 7. júní 2008 um breytingu á lögum um staðfesta samvist, nr. 87/1996, með síðari breytingum. "Tóku ekki afstöðu," mbl.is, 29 April 2020. I thank Porvaldur Kristinsson for clarifying the position of the Church of Iceland.

64 Kuosmanen 2009.

65 Love 2009, 72.

66 Private conversation with Hrafnkell Tjörvi Stefánsson, I5 October 2005.

67 Herburt 2009. 


\section{Odd Couples}

\section{Notes summary and conclusions}

I Wennerfors agreed to present a private member's bill to the Riksdag in 1971, calling for the abolition of the higher age of consent for homosexual relations. Rydström $2007 \mathrm{~b}, 205$. Jörn Svensson was the MP who most consistently worked for lesbian and gay rights in the Swedish Parliament during the I970s.

2 http://www.norden.org/da/fakta-om-norden/politikk. Viewed 22 April 2010.

3 Lag (2006:35I) om genetisk integritet m.m. 6 kap. 5 .

4 Assisted reproduction 2006.

5 Rubin 1993 (1984), 13.

6 "là, où il y a pouvoir, il y a résistance." Foucault I976, I25. 


\section{Appendix: Political parties and gay and lesbian rights groups in Scandinavia}

\section{Political parties}

This list of political parties is meant to help the reader find more easily her or his way through the jungle of political parties in the Scandinavian countries. It does not pretend to be a complete account of Scandinavia's political history, and for practical reasons, much information about shifting names and party splits has been omitted. For a more comprehensive account of the Scandinavian party system, see Grofman and Lijphart 2002.

\section{Denmark}

\section{Socialist parties}

Centre Democrats (Centrumdemokraterne, CD). Founded in 1973 by right-wing Social Democrats. Dismantled in 2008. Represented in the Folketing 1973-200I.

Left Socialist Party (Venstresocialisterne, VS). Founded in 1967. Dismantled in 1998. Represented in the Folketing 1968-1971, 1975-1987.

Red-Green Alliance (Enhedslisten - De Rød-Gronne). Founded in 1989. Represented in the Folketing since 1994. Merger of the Danish Communist Party, The Left Socialist Party, and the Socialist Worker's Party. LGBT issues and diversity high on the agenda.

Socialist People's Party ( $S F$ - Socialistisk Folkeparti). Founded as a splinter group from the Danish Communist Party in 1958, in protest against the DCP's close contacts with Moscow. Represented in the Folketing since 1958.

Social Democrats (Socialdemokraterne). Founded in 1871. Represented in the Folketing since 1884 . 


\section{Liberal parties}

Radical Left Party (Radikale Venstre, RV). Left-of-centre liberals. Founded in 1905 as a splinter group from the Left Party over the issue of defence spendings. Represented in the Folketing since 1905.

\section{Centre parties}

Left Party, Denmark's Liberal Party (Venstre, Danmarks liberale parti), right-of-centre liberals. Founded in 1870 . Represented in the Folketing since I870.

\section{Conservative parties}

Conservative People's Party (Konservative Folkeparti). Founded in 1915. Represented in the Folketing since I9I5.

\section{Christian democratic parties}

Christian Democratic Party (Kristendemokraterne, KD, before 2003 Kristeligt Folkeparti). Founded in 1970. Represented in the Folketing 1973-1994, 1998-2005.

\section{Right-wing populist parties}

Progress Party (Fremskridtspartiet, FrP). Founded in 1972. Represented in the Folketing 1973-1999.

Danish People's Party (Dansk Folkeparti). Founded in 1995 by Progress Party MPs. Represented in the Folketing since 1995.

\section{The Faroe Islands}

\section{Socialist parties}

Social Democratic Party (Javnadarflokkurin). Founded in 1926. Represented in the Logting since 1928.

Republican Party (Tjódveldisflokkurin, from 2007 Tjódveldi). Socialist party working for independence. Founded in 1948. Represented in the Logting since I950.

\section{Liberal parties}

Independence Party (Sjálfstýrisfokkurin). Centre liberal party working for independence. Formally founded in I909. Represented in the Logting since 1906.

Unionist Party (Sambandsflokkurin). Liberal party in favour of tight bonds with Denmark. Founded in 1906. Represented in the Logting since 1906. 


\section{Conservative parties}

Centre Party (Midflokkurin). Christian party working for traditional values. Founded in 1992. Represented in the Logting since 1992.

People's Party (Folkaflokkurin). Conservative party. Founded in 1939. Represented in the Logting since 1939.

\section{Finland}

\section{Socialist parties}

Finnish Communist Party (Suomen Kommunistinen Puolue / Finlands Kommunistiska Parti) I918-1990. Illegal until I945, then worked in close cooperation with the Finnish People's Democratic Alliance until both parties were dismantled in 1990 and their work was carried on by the Left Alliance.

Finnish People's Democratic Alliance (Suomen Kansan Demokraattinen Liitto/Demokratiska Förbundet för Finlands Folk, SKDL/DFFF), 1944-1990. Also known as the People's Democrats (Kansandemokraatit / Folkdemokraterna). Leftist socialist umbrella organisation for political forces to the left of the Social Democrats.

Left Alliance (Vasemmistoliitto / Vänsterförbundet), 1990-

Social Democratic Party (Suomen Sosialidemokraattinen Puolue, SDP/Finlands Socialdemokratiska Parti). 1899-

\section{Liberal parties}

Finnish People's Party (Suomen Kansanpuolue / Finska Folkpartiet). Liberal People's Party created after a party split. 195-1965.

Freethinkers' League (Vapaamielisten Liitto / Frisinnade Förbundet). Liberal party created after a party split. 1951-1965.

Liberal People's Party (Liberaalinen Kansanpuolue / Liberala Folkpartiet, LKP/LFP after 2000 Liberaalit / Liberalerna, LKP/LFP). Created as a merger between the Finnish People's Party and the Freethinkers' League. 1965-

Swedish People's Party (Ruotsalainen Kansanpuolue/Svenska Folkpartiet, RKP/SFP). Liberal party with its electorate among the Swedish-speaking minority in Finland. 1906-

\section{Environmentalist parties}

Green Alliance (Vibreä Liitto / Gröna Förbundet). Liberal-left environmentalist party. 1987-

\section{Centre parties}

Centre Party (Suomen Keskusta / Centern i Finland, before 1965 the Agrarian League, Maalaisliitto / Agrarförbundet). 1906- 
Conservative parties

National Coalition (Kansallinen Kokoomus/Samlingspartiet). Conservative party. 1918-

\section{Christian democratic parties}

Christian Democrats (Kristillisdemokraatit / Kristdemokraterna i Finland). Founded by Christian former members of the National Coalition. 1958-

\section{Right-wing populist parties}

Finnish Countryside Party (Suomen Maaseudun Puolue / Finlands Landsbygdsparti). Right-wing populist party. 1959-1995.

True Finns (Perussuomalaiset / Sannfinländarna). Right-wing populist party. 1995-

\section{Greenland}

\section{Socialist parties}

Social Democratic Party (Siumut, lit. "Forward"). The continuation of a movement against Danish colonialism. I977-

Socialist Party (Inuit Ataqatigiit, or IA, lit. Human [or Greenlandic] Solidarity). Socialist party working for increased Greenlandic self-governance. 1978-

\section{Liberal parties}

Greenland's Democrats (Kalaallit Nunaani Demokraatit). Social liberal party. 2005-

\section{Conservative parties}

Liberal-Conservative Party (Atassut, lit. "Connection”). Sister party to the Danish party Venstre and can be characterised as an economically liberal party with a traditionalist value ground. Emphasises the common grounds of Danish and Greenlandic values. $1978^{-}$

\section{Iceland}

\section{Socialist parties}

United Left Party (Samfylkingin). A fusion of the Social Democratic Party, the Women's List, and the People's Alliance. 2000- 
Left-Green Party (Vinstribreyfingin-Grent frambod). Splinter group from the People's Alliance when it abandoned its opposition to NATO. 1999-

Socialist Alliance (Bandalag jafnadarmanna). Short-lived socialist party that got four seats in Parliament in the 1985 elections. The next year, three of these joined the Social Democratic Party, and the fourth became an independent MP. 1985-I986.

People's Alliance (Alpýdubandalagið). Created after a fusion of the Icelandic Communist Party and another splinter group from the Social Democrats. Merged with Social Democrats and formed United Left Party. 1956-I998.

Social Democratic Party (Alpýduflokkurinn). Merged with People's Alliance and Women's List and formed United Left Party. 1916-1998.

\section{Feminist parties}

Women's List (Kvennalistinn) I983-1998.

\section{Centre parties}

Progressive Party (Framsóknarflokkurin). Centre liberal. I9ı6-

\section{Conservative parties}

Independence Party (Sjálfstęisflokkurin). Moderately conservative. I907-

\section{Parties of Discontent}

Citizens' Movement (Borgarahreyfingin). Created in connection with the financial crisis in 2009, and obtained four seats in Parliament in the 2009 elections.

The Movement (Hreyfingin). Splinter party from the Citizens' Movement from September 2009. Three seats in Parliament.

\section{Norway}

\section{Socialist parties}

Marxist-Leninist Workers Communist Party (Arbeidernes Kommunistiske Parti [marxist-leninistene], AKP [m-1]). I973-2007. Gay-friendly, revolutionary party with a marginal political influence but with a large influence on Norwegian intellectuals in the r970s and r980s.

Labour Party (Arbeiderpartiet, AP). I887-

Socialist Left Party (Sosialistisk Venstreparti, SV). Created after a fusion of Norway's Communist Party, Democratic Socialists, and some independent socialists. 1975- 


\section{Liberal parties}

Left Party (Venstre). Classical social-liberal party with an urban electorate. 1884-

\section{Centre parties}

Centre Party (Senterpartiet. Before 1959 Norsk Bondelag, or Norwegian Farmers'Union). Rural party with a strong Christian constituency, but increasingly liberal. 1920-

\section{Conservative parties}

Right Party (Høyre). I884-

\section{Christian democratic parties}

Christian People's Party (Kristelig Folkeparti). Founded as a reaction to liberal abortion laws. 1933-

\section{Right-wing populist parties}

Progress Party (Fremskrittspartiet). Right-wing populist party. 1973-

\section{Sweden}

\section{Socialist parties}

Left Party (Vänsterpartiet) I9I7-. Earlier names were Sweden's Social Democratic Left Party (Sveriges Socialdemokratiska Vänsterparti) I9I7-I92I, Sweden's Communist Party (Sveriges Kommunistiska Parti) I92I-I967, Left Communist Party (Vänsterpartiet Kommunisterna, VPK) I967-I990.

Social Democratic Party (Socialdemokratiska Arbetarpartiet, SAP). I889-

\section{Liberal parties}

People's Party the Liberals (Folkpartiet liberalerna). Classical liberal party, traditionally with internal tensions between urban social-liberals and rural Christian voters. 1902-

\section{Centre parties}

Centre Party (Centerpartiet, before 1957 Farmers' League [Bondeförbundet]). Agrarian party. I9I3- 


\section{Environmentalist parties}

Environment Party (Miljöpartiet de gröna). Left-liberal environmentalist party. 1981-

\section{Feminist parties}

Feminist Initiative (Feministiskt Initiativ, $F$ i). Feminist party led by former Left Party leader Gudrun Schyman. Not represented in Parliament but with considerable influence in the public debate. 2006-

\section{Conservative parties}

Moderates (Moderaterna, or Moderata Samlingspartiet, before 1969 Högerpartiet, or the Right Party). Moderately Conservative party. 1904-

\section{Christian democratic parties}

Christian Democrats (Kristdemokraterna). Founded as a protest against the liberalisation of abortion laws. 1964-

\section{Right-wing populist parties}

New Democracy (Ny Demokrati). Right-wing populist party, in Parliament I99I-I994.

\section{Gay and lesbian movements: National organisations}

The list includes only the national organisations. Lesbian groups, students' organisations, gay and lesbian s/m organisations, and gay parents' associations (both for lesbian and gay parents and for parents of lesbians and gays) have played important parts for lesbian and gay rights in all Scandinavian countries. However, the large, national lesbian and gay organisations were traditionally seen as a kind of "trade unions" for lesbians and gay men. In recent years, most of them have broadened their mandate to include bisexuals and transgendered people, which is obvious in a number of name changes.

\section{Denmark}

Kredsen af 1948 (The Circle of 1948). I948.

Forbundet af 1948 (The Society of 1948). 1949-1982.

Landsforeningen for Bøsser og Lesbiske, Forbundet af 1948 (National Union for Gays and Lesbians, The Society of 1948), LBL. 1982-2009.

LGBT Danmark - Landsforeningen for bøsser, lesbiske, biseksuelle og transpersoner (LGBT Denmark - National Union for Gays, Lesbians, Bisexuals and Transgendered). 2009- 


\section{The Faroe Islands}

Ælabogin (The Rainbow). 2003.

Friðarbogin, felag fyri sam- og tvíkyndar føroyingar (The Peace Bow, Association for Homo- and Bisexual Faroese). 2003-

\section{Finland}

Keskusteluseura Psyke / Diskussionsklubben Psyke (Discussion Club Psyche). r968-ı988. Seksuaalinen Tasavertaisuus / Sexuellt Likaberättigande, SETA (Sexual Equality). 1974-

\section{Greenland}

Qaamaneq (The Light). 2002-2007.

\section{Iceland}

Samtökin '78 - félag lesbía og homma á Íslandi (The Society of' 78 - The Lesbian and Gay Organisation of Iceland). 1978-2009.

Samtökin '78 - félag hinsegin fólks á Íslandi (The Society of '78 - Queer People's Organisation of Iceland). 2009-

\section{Norway}

Det Norske Forbund av 1948 (The Norwegian Society of I948), DNF'48. I950-I992.

Fellesrådet for Homofile Organisasjoner (Joint Council for Homophile Organisations), FHO. The FHO consisted of a number of local organisations, among which was the Oslo-based group Arbeidsgrupper for Homofil Frigjøring, AHF (Working Groups for Homosexual Liberation), and the Bergen-based Homofil Bevegelse i Bergen, HBB (Homosexual Movement in Bergen). 1979-1992.

Landsforeningen for Lesbisk og Homofil Frigjøring (National Union for Lesbian and Gay Liberation), LLH. 1992-2008.

LLH - Landsforeningen for lesbiske, homofile, bifile og transpersoner (LLH - National Union for Lesbians, Gays, Bisexuals, and Transgendered Persons). 2008-

The national gay and lesbian movements in Norway were separate from 1979 till 1992, when the two organisations merged.

\section{Sweden}

Förbundet av 1948 - Svenska sektionen (The Swedish Section of The Society of 1948). I950-I952.

Riksförbundet för Sexuellt Likaberättigande (National Union for Sexual Equality), RFSL. 1952-2007.

RFSL - Riksförbundet för homosexuellas, bisexuellas och transpersoners rättigheter (RFSL - National Union for Lesbian, Gay, Bisexual and Transgender Rights). 2007- 


\section{References}

\section{Unpublished sources}

\section{Interviews}

(The language of the interview is specified only when conducted in a language other than the interviewee's mother tongue.)

Anders and Folke C., gay men. Stockholm, March 1997.

Andreasson, Martin, politician (People's Party). Telephone interview, 2I January 2004.

Bønnelykke, Per Kleis, activist, Denmark. Kruså, 2 May 2005.

Christensen, Henning, and Anna Qvist, statisticians, Denmark. Copenhagen, 5 May 2008.

Eddudóttir, Lana Kolbrún, activist, Iceland. Reykjavík, I3 October 2005. Interview conducted in Swedish.

Frevert, Louise, politician (Progress Party), Denmark. Copenhagen, 28 February 2005.

Friele, Karen Christine (Kim), activist, Norway. Haugastøl, I4 September 2005.

Gísladóttir, Guðrún, activist, Iceland. Copenhagen, II May 2005. Interview conducted in Swedish.

Gjellerup, Pia, politician (Social Democrats), Denmark. Copenhagen, 9 December 2005.

Halvorsen, Kristin, politician (Socialist Left Party), Norway. Oslo, 22 November 2004.

Hansen, Bent, activist, Denmark. Copenhagen, 28 February 2005.

Hentilä, Jorma, politician (The Democratic Union of Finland's People), Finland. Helsinki, 20 April 2005. Interview conducted in Swedish.

Hiltunen, Rainer, activist, Finland. Helsinki, I9 April 2005. Interview conducted in English.

Hoydal, Høgni, politician (Republican Party), Faroes. Tórshavn, 28 August 2005. Interview conducted in Swedish.

Jensrud, Trond, politician (Labour Party), Norway. Oslo, 24 November 2004.

Jógvansdóttir, Sonja, activist, Faroes. Copenhagen, II May 2005. Interview conducted in Danish.

Jørgensen, Regine and Estrella Mølgaard, activists, Greenland. Nuuk, 22 September 2005. Interview conducted in Danish.

Juvas, Sören, activist, Sweden. Stockholm, I8 September 2009.

Kivinen, Tiina, activist, Finland. Helsinki, 20 April 2005. Interview conduced in English.

Kjølbro, Karin, politician (Republican Party), Faroes. Tórshavn, 26 August 2005. Interview conducted in Danish. 
Kristinsson, Porvaldur, activist, Iceland. Reykjavík, I3 December 2005. Interview conducted in English.

Lehtonen, Jukka, and Kati Mustola, activists, Finland. Helsinki, 20 April 2005. Interview conducted in English.

Lööw, Maj-Lis, politician (Social Democratic Party), Sweden. Stockholm, 25 November 2005 .

Lund, Torben, politician (Social Democratic Party), Denmark. Copenhagen, 3 March 2005 .

Månsson, Ulf, activist, Finland. Helsinki, 20 April 2005 .

Mohr, Anna, activist, Sweden. Stockholm, 3 June 2005.

Moti, Manijeh Elsa, activist, Faroes. Copenhagen ro May 2005. Interview conducted in Danish.

Mustola, Kati, activist, Finland. Telephone interview, I5 November 2005. Interview conducted in Swedish.

Øie, Kjell Erik, and Mette Sørensen, activists, Norway. Oslo, 22 November 2004.

Olsen, Erik, activist, Greenland, Tórshavn, 27 August 2005. Interview conducted in Danish.

Pareli, Leif, activist, Norway. Telephone interview, 23 April 20 Io.

Petersson, Stig-Åke, activist, Sweden. Stockholm, 3 June 2005.

Rosen, Wilhelm von, activist, Denmark. Copenhagen, I March 2005.

Saarinen, Terhi, activist, Finland. Helsinki, Ig April 2005. Interview conducted in English.

Semionsen, Tom, activist, Greeenland. Nuuk, 29 September 2005. Interview conducted in Danish.

Slange, Else, activist, Denmark. Copenhagen, I March 2005.

Sólrun Gísladóttir, Ingibjörg, politician (United Left Party), Iceland. Reykjavík, I4 October 2005. Interview conducted in Danish.

Spaak, Carl-Anton, Judge, Stockholm, Sweden. Telephone interview, 8 January 2004. Stafilidis, Tasso, politician (Left Party), Sweden. Telephone interview, Io February 2004. Svahn, Birgitta, civil servant, Tidaholm, Sweden. Telephone interview, I8 December 2003. Westerholm, Barbro, politician (Liberal Party), Sweden. Stockholm, 2I November 2005. Wikström, Tobias, activist, Sweden. Stockholm, I June 2005.

\section{Archives}

Denmark:

Polarbiblioteket, Copenhagen (PB)

[Arctic Library]

Greenlandic newspapers

Atuagagdliutit / Gronlandsposten (AG), 1989-2005

Sermitsiaq, 1989-2005

Justitsministeriet, Copenhagen (JMC)

[Ministry of Justice]

Journal Nr. 1994-7770-0002

Landsforeningen for Bøsser og Lesbiske, Copenhagen (LBL) 
[National Association for Gays and Lesbians]

Hovedbestyrelsen

Newspaper clippings

\section{Finland:}

Työväen Arkisto, Helsinki (TA)

[The Finnish Labour Archives]

SETA Archives 1968-1999

Seksuaalinen Tasavertaisuus, Helsinki (SETA)

[Finnish Association for Sexual Equality]

SETA Archives from 2000

Newspaper clippings

\section{Iceland:}

Borgarskjalasafn Reykjavíkur (BR)

[Reykjavík Town Archives]

Samtökin '78 Archives 1978-1999

Samtökin '78 - Félag lesbia og homma á Íslandi, Reykjavík (Samtökin '78)

[The Federation of ' 78 - The association for gays and lesbians in Iceland]

Samtökin' 78 Archives from 2000

Newspaper clippings

Norway:

Landsforeningen for Lesbisk og Homofil Frigjøring, Oslo (LLH)

[National Association for Gay and lesbian Liberation]

LLH Archives

Newspaper clippings

Riksarkivet, Oslo (RAN)

[National Archives]

Archives of the National Federation of 1948 (DNF' 48 )

Kim Friele, private archives, Haugastøl

Sweden:

Riksarkivet, Stockholm (RAS)

[National Archives]

RFSL Archives I950-I970

Socialstyrelsen

Arbetarrörelsens Arkiv och Bibliotek, Stockholm (ARAB)

[Archives and Library of the Workers' Movement]

Social Democratic Party Archives

Riksdagsbiblioteket, Stockholm (RB) 
[Library of the Swedish Parliament]

Voting Charts

Riksförbundet för Sexuellt Likaberättigande, Stockholm (RFSL)

[National Federation for Sexual Equality]

RFSL Archives from 1970

Newspaper clippings

\section{Official print}

Alpingistidindi. 1992-2010. Reykjavík: Icelandic Parliamentary Print.

Agteskabs indgåelse og oplosning samt forcldremyndighed og samkvemsret. Betænkning II fra Justitsministeriets Ægteskabsudvalg. Betænkning nr. 369 September 1964. København: J. H. Schultz.

Folketingets årbog. I968-1987. Copenhagen: Danish Parliament's Yearbook.

Folketingstidende. 1968-2010. Copenhagen: Danish Parliamentary Print.

Homoseksuelles vilkair: Afgivet af Kommissionen til belysning af homoseksuelles situation $i$ samfundet. I988. Betænkning II27. Copenhagen: Statens informationstjeneste.

Inatsisartut/Landstinget. 1994-2009. Landstingets forhandlinger. Fortryk. Nuuk: Nanoq.

Laki ja samaa sukupuolta olevien parisubteet: työryhmän ehdotus. Oikeusministeriön lainvalmisteluosaston julkaisu 2/1999. Oikeusministeriö: Edita I999.

Nytt juridiskt arkiv 1955 .

Perheen sisäinen adoptio rekisteröidyn parin perheessä. 2008. Lausuntoja ja selvityksiä / Oikeusministeriö 2008:I2.

Perhekomitean mietintö. I992. Helsinki.

Riksdagen. 1973-2010. Stockholm: Swedish Parliamentary Print.

Skýrsla nefndar um málefni samkynhneigdra. 1994. Report to the Icelandic Parliament on the living conditions of homosexuals. Reykjavík: Forsætisráðuneytið.

Skýrsla um réttarstödu samkynhneigdra. 2004. Report to the Icelandic Parliament on homosexuals' rights. Reykjavík: Forsætisráðuneytið.

SOU (Statens Offentliga Utredningar) 1972:4I. Familj och äktenskap: Betänkande. I. 1972. Familjelagssakkunniga. Stockholm: Justitiedepartementet.

SOU I984:63. Homosexuella och sambället: Betänkande av utredningen om homosexuellas situation $i$ sambället. 1984. Stockholm: Liber/Allmänna Förlaget.

SOU 1993:98. Partnerskap: Betänkande av Partnerskapskommittén. Stockholm: Allmänna Förlaget.

SOU 2000:88. Organiserad brottslighet, hets mot folkgrupp, hets mot homosexuella, m.m. straffansvarets räckvidd: Betänkande frän Kommittén om straffansvar för organiserad brottslighet m.m. Stockholm: Justitiedepartementet.

SOU 20or:Io. Barn i homosexuella familjer: Betänkande från Kommittén om barn i homosexuella familjer. Stockholm: Justitiedepartementet.

SOU 2007:3. Föräldraskap vid assisterad befruktning: Utredningen om föräldraskap vid assisterad befruktning. Stockholm: Justitiedepartementet.

SOU 2007:I7. Äktenskap för par med samma kön: Vigselfrågor. Betänkande av Äktenskaps- och partnerskapsutredningen. Stockholm: Fritze. 
Stortingets forhandlinger.

Swedish Social Democratic Party Print. Stockholm.

\section{Literature}

Aamma illit inuuneraat ... HIV AIDS-ilu pillugit oqaluttuat/Livet er også dit . . Historier om HIV og AIDS. 2004. Nuuk: Paarisa.

Adeniji, Anna. 2008. Inte den typ som gifter sig: Feministiska samtal om äktenskapsmotstånd. Göteborg: Makadam.

Ahlgren, Stig. 1966, Den okände Karl Gerhard. Stockholm: Bonnier.

Albæk, Erik. 1998. "Frisindets grænser: Homoseksuelle mellem moralske dilemmaer og politiske hensyn." Politica 30: 4, 405-2I.

Altman, Dennis. 20or. Global sex. Chicago: University of Chicago Press.

Alving, Barbro, and Ruffa Alving-Olin. 2009. Bang om Bang. Urval, inledning och kommentarer av Ruffa Alving-Olin. Möklinta: Gidlund.

Åmark, Klas. 2005. Hundra år av välfärdspolitik: Välfärdsstatens framväxt $i$ Norge och Sverige. Umeå: Boréa.

Andersen, Jørgen Goul, and Jan Bendix Jensen. 200I. "The Danish Venstre: Liberal, agrarian or centrist?" In From farmyard to city square? The electoral adaptation of the Nordic agrarian parties. Ed. David Arter. Aldershot: Ashgate.

Anderssen, Norman, Christine Amlie, and Erling André Ytterøy. 2002. "Outcomes for children with gay and lesbian parents: A review of studies from 1978-2000. Scandinavian Journal of Psychology 43:4, 335-51.

Andersson, Gunnar, Turid Noack, Ane Seierstad, and Harald Weedon-Fekjær. 2006. "The demographics of same-sex marriages in Norway and Sweden." Demography 43:I, 79-98.

Andreasson, Martin. 2000. "Samhällsfara eller samhällsgrupp? Riksdagens syn på homooch bisexuella." In Homo i folkhemmet: Homo- och bisexuella i Sverige 1950-200o. Ed. Martin Andreasson, 36-58. Göteborg: Anamma.

Antorini, Christine. 2008. Fremtidens partier. København: Gyldendal.

Arter, David. 1978. Bumpkin against Bigwig: The emergence of a green movement in Finnish politics. Tampere: Tampereen yliopisto.

- . 1999. "Party system change in Scandinavia since 1970: 'Restricted change' or 'General change'?" West European Politics 22:3, 139-58.

- . 200Ia. Ed. From farmyard to city square? The electoral adaptation of the Nordic agrarian parties. Aldershot: Ashgate.

- . 20orb. "The Finnish Centre Party: A case of successful transformation?" In From farmyard to city square? The electoral adaptation of the Nordic agrarian parties. Ed. David Arter, 59-95. Aldershot: Ashgate.

- . 2008. Scandinavian politics today. Manchester: Manchester University Press.

Ashbee, Edward. 2005. "The same-sex marriage debate in the US and representations in Scandinavia." Journal of Transatlantic Studies 3:2, 159-77.

Assisted reproduction in the Nordic countries: A comparative study of policies and regulation. 2006. København: Nordisk Ministerråd. 
Axgil, Axel, and Helmer Fogedgaard. 1985. Homofile kampår: Bøsseliv gennem tiderne. Rudkøbing: Grafolio.

Badgett, M. V. Lee. 200I. Money, myths and change: The economic lives of lesbians and gay men. Chicago: University of Chicago Press.

- . 2009. When gay people get married: What happens when societies legalize same-sex marriage? New York: New York University Press.

Banens, Maks, and Rommel Mendès-Leite. 2008. Nouvelles visibilités, novelles discriminations? Rapport à l'adresse du Ministère de l'Emploi, de la Cohésion sociale et du Logement et du Ministère de la Santé et des Solidarités. Drees-Mire.

Bech, Henning. 1992. "Report from a rotten state: 'Marriage' and 'homosexuality' in 'Denmark."' In Modern homosexualities: Fragments of gay and lesbian experience. Ed. Ken Plummer, 134-47. London and New York: Routledge.

- . I997. When men meet: Homosexuality and modernity. Cambridge: Polity Press.

Bell, Mark. 20or. "Sexual orientation discrimination in employment: An evolving role for the European Union." In Legal recognition of same-sex partnerships: A study of national, European and international law. Eds. Robert Wintemute and Mads Andenæs, 654-76. Oxford and Portland: Hart Publishing.

Bengtson, Eva-Lisa. 1998. "Homosexuellas historia i Stockholm. Del 4," På Gång: Medlemstidning för RFSL Stockholm (November), I6-I7.

Bergh, Steinar, and Finn Jensen, "Sekteristisk eller progressiv homsekamp?" Løvetann, No. 2.

Bertilsdotter Rosqvist, Hanna. 2009. "Vi tar farväl av pianoläraren: Retoriska konstruktioner av en homosexuell manlig subjektivitet utifrån tal om öppenhet och homosexuell exklusivitet i svensk homopress 1965-1986.” Historisk Tidskrift (Stockholm) I29:3, 5II-29.

Black, Dan, Gary J. Gates, Seth G. Sanders, and Lowell Taylor. 20oo.”Demographics of the gay and lesbian population of the United States: Evidence from available systematic data sources." Demography 37, I39-I54

Borrillo, Daniel, and Pierre Lascoumes. 2002. Amours égales? Le Pacs, les homosexuels et la Gauche. Paris: La Découverte.

Borrillo, Daniel, and Eric Fassin. 1999. Au-delà du PaCS: L'expertise familiale à l'épreuve de l'homosexualité. Paris: Presses Universitaires de France.

Bosinski, Hartmut A. G., Paul Kirchhof, Rosemarie Nave-Herz, Gerhard Robbers, and Hans Rotter. 200I. et al., "Eingetragene Lebenspartnerschaft": Rechtssicherheit für homosexuelle Paare - Angriff auf Ehe und Familie? Regensburg: Pustet.

Boswell, John. 1980. Christianity, social tolerance, and homosexuality: Gay people in western Europe from the beginning of the Christian era to the fourteenth century. Chicago: University of Chicago Press.

Bradley, David. 1996. Family law and political culture: Scandinavian laws in comparative perspective. London: Sweet \& Maxwell.

Brickell, Chris. 2008. Mates and lovers: A history of gay New Zealand. Auckland: Random House.

Broberg, Gunnar, and Nils Roll-Hansen. I996. Eds. Eugenics and the welfare state: Sterilization policy in Denmark, Sweden, Norway, and Finland. East Lansing: Michigan State University Press. 
Bryld, Mette. 200I. "The infertility clinic and the birth of the lesbian: The political debate on assisted reproduction in Denmark." European Journal of Women's Studies 8:3, 299-312.

Butler,Judith. I993. "Critically queer." GLQ. A Journal of Gay and lesbian Studies. I:I, I7-32.

- . 2000. Antigone's claim: Kinship between life and death. New York: Columbia University Press.

- . 2002. "Is kinship always already heterosexual?" Differences I3:I, I4-44.

Cantera Carlomagno, Marcos. 20or. Ed. När Alving blev Bang. Lund: Historiska media. Carpenter, Christopher, and Gary J. Gates. 2008. "Gay and lesbian partnership: Evidence from California." Demography 45, 573-590.

Chambon, Laurent. 2005. "Le placard universaliste: Quand la République se fait particulariste contre les gays." Mouvements 38, 34-40.

Chauncey, George Jr. 2004. Why marriage? The history shaping today's debate over gay equality. New York: Basic Books.

Chenier, Elise. 2008. "Freak Wedding!' Lesbian marriage as a pleasure practice in PostWWII Toronto." Paper presented at the Seventh European Social Science History Conference, Lisbon, March I.

Chou, Wah-shan. 2000. Tongzhi: Politics of same-sex eroticism in Chinese societies. New York: Haworth Press.

Christensen, Birgit Westphal. I989. AIDS: Prevention og kontrol i Norden. Göteborg: Nordiska Hälsovårdshögskolan.

Christensen, Dag Arne. 200I. "The Norwegian Agrarian-Centre Party: Class, rural or catchall-party?" In From farmyard to city square? The electoral adaptation of the Nordic agrarian parties. Ed. David Arter, 3-30. Aldershot: Ashgate.

Christensen, Søren Kai, and Tage Søndergård Kristensen. 1972. Kollektiver i Danmark. København: Borgen/Basis.

Christiansen, Niels Finn, and Klaus Petersen. 2001. Eds. The Nordic welfare states 190o200o. Special issue of Scandinavian Journal of History 26:3.

Christiansen, Niels Finn, Klaus Petersen, Nils Edling, and Per Haave. 2006. Eds. The Nordic model of welfare: A historical reappraisal. Copenhagen: Museum Tusculanum.

Cooper, Davina. 20or. "Like counting stars? Re-structuring equality and the socio-legal space of same-sex marriage." In Legal recognition of same-sex partnerships: A study of national, European and international law. Eds. Robert Wintemute and Mads Andenæs, 75-96. Oxford and Portland: Hart Publishing.

Cvetkovich, Ann. 2003. An archive of feelings: Trauma, sexuality, and lesbian public cultures. Durham, NC: Duke University Press.

Danielsen, Svend, and Peter Lødrup. 1988. "Det nordiske samarbeidet på familierettens område." Tidsskrift for rettsvitenskap IoI, $565-585$.

D'Emilio, John. 1983. Sexual politics, sexual communities: The making of a homosexual minority in the United States, 1940-1970. Chicago : University of Chicago Press.

Demker, Marie, and Lars Svåsand. Eds. 2005. Partiernas århundrade: Fempartimodellens uppgång och fall i Norge och Sverige. Stockholm: Santérus.

Digoix, Marie, and Patrick Festy. 2004. Eds. Same-sex couples, same-sex partnerships, and homosexual marriages: A focus on cross-national differentials. Documents de travail I24. Paris: INED. www.ined.fr. 
Dinshaw, Carolyn. 1999. Getting medieval: Sexualities and communities, pre- and postmodern. Durham, NC: Duke University Press.

Dittberner, Mareike. 2004. Lebenspartnerschaft und Kindschaftsrecht: Die rechtliche Situation gleichgeschlechtlicher Paare unter besonderer Berücksichtigung kindschaftsrechtlicher Regelungen. Frankfurt am Main: Lang.

Dover, K. J. I989. Greek homosexuality. Updated and with a new postscript. Cambridge, MA: Harvard University Press.

Duggan, Lisa. 2002. "The new homonormativity: The sexual politics of neoliberalism." In Materialising democracy: Toward a revitalized cultural politics. Ed. Russ Castronovo and Dana D. Nelson. Durham, NC: Duke University Press.

- . 2004a. The twilight of equality? Neoliberalism, cultural politics, and the attack on democracy. Boston: Beacon.

- . 2004b. "Holy matrimony!" The Nation (March 15).

Duggan, Lisa, and Richard Kim. 2005. "Beyond gay marriage." The Nation (July 18).

Dunne, Gillian. 2000. "Opting into motherhood: 'That's our kind of constellation." Gender and Society I4:I, II-6I.

Dunton, Chris, and Mai Palmberg. 1996. Human rights and homosexuality in Southern Africa. Uppsala: Nordiska Afrikainstitutet.

Edelman, Lee. 2004. No future: Queer theory and the death drive. Durham, DC: Duke University Press.

Edström, Vivi. 2002. Selma Lagerlöf: Livets vågspel. Stockholm: Natur och Kultur.

Einarsdóttir, Anna. 2008. "The love of my life": Stories of same-sex "marriage" in Iceland. Unpublished $\mathrm{PhD}$ thesis. London: London South Bank University.

El-Rouayheb, Khaled. 2005. Before homosexuality in the Arab-Islamic world. Chicago: University of Chicago Press.

Eman, Greger. 2000. “Klänningens betydelse för mänsklighetens frigörelse.” In Homo i folkhemmet: Homo- och bisexuella i Sverige 1950-2000. Ed. Martin Andreasson, I55I75. Göteborg: Anamma.

Eskridge, William N. Jr., Darren R. Spedale, and Hans Ytterberg. 2004. "Nordic bliss? Scandinavian registered partnerships and the same-sex marriage debate." Issues in Legal Scholarship I:5, I055.

Eskridge, William N. Jr., and Darren R. Spedale. 2006. Gay marriage: For better or for worse? What we've learned from evidence. Oxford and New York: Oxford University Press.

Esping-Andersen, Gøsta. 1985. Politics against markets: The social democratic road to power. Princeton, NJ: Princeton University Press.

- . I990. The three worlds of welfare capitalism. Cambridge: Polity Press.

Familjen iframtiden: En socialistisk familjepolitik. 1974. Report to the Social Democratic Party Congress. Stockholm: Sveriges socialdemokratiska kvinnoförbund.

Fassin, Éric. 2005. L'Inversion de la question homosexuelle. Paris: Éditions Amsterdam.

Festy, Patrick. 200I. “The 'Civil Solidarity Pact' (PaCS) in France: An impossible evaluation." Population et sociétés no. 369. URL (accessed October 2007): www.ined.fr/ fichier/t_publication/697/ publi_pdf2_pop_and_soc_english_369.pdf 
Flaks, David K., Ilda Fisher, Frank Masterpasqua, and Gregory Joseph. 1995. "Lesbians choosing motherhood: A comparative study of lesbian and heterosexual parents and their children." Developmental Psychology 31:I, I05-I4.

Foucault, Michel. 1971. "Nietzsche, la généalogie, l'histoire." In Hommage à Jean Hyppolite. By Suzanne Bachelard, Georges Canguilhem, François Dagognet, Michel Foucault et al. Paris: Presses Universitaires de France.

- . 1975. Surveiller et punir: Naissance de la prison. Paris: Gallimard.

- . I976. Histoire de la sexualité: La volonté de savoir. Paris: Gallimard.

- . 1991. Remarks on Marx: Conversations with Duccio Trombadori. Translated by R. James Goldstein and James Cascaito. New York: Semiotext(e).

Frankland, E. Gene, Paul Lucardie, and Benoît Rihoux. Eds. 2008. Green parties in transition: The end of grass-roots democracy? Aldershot: Ashgate.

Fraser, Nancy. 1997. Justice interruptus: Critical reflections on the "postsocialist" condition. London: Routledge.

- . 2008. Scales of justice: Reimagining political space in a globalizing world. Cambridge: Polity Press.

Fraser, Nancy, and Axel Honneth. 20or. Redistribution or recognition? A philosophical exchange. London: Verso.

Friele, Karen-Christine. 1975. Fra undertrykkelse til oppror: Om à vare homofil-og vare glad for det. Oslo: Gyldendal.

- . I985. De forsvant bare: Fragmenter av homofiles historie. Oslo: Gyldendal.

- . 1990. Troll skal temmes. Oslo: Scanbok forlag.

- . 2000. "Med regnbuen som våpen: Fragmenter av norsk homohistorie gjennom 50 år." lambda nordica 6:2/3, 42-66.

- . 2004. "Historien om et 'Fråsegn om homofili'," Blikk II (I April).

Gabb, Jacqui. 2005. "Lesbian M/Otherhood: Strategies of familial-linguistic management in lesbian parent families." Sociology 39:4, 585-603.

Gerhard, Kirsten. 2009. Die eingetragene Lebenspartnerschaft: Eine historisch-dogmatische Bestandsaufnahme zur Frage nach einem neuen familienrechtlichen Institut. Göttingen: Sierke.

Giddens, Anthony. 1992. The transformation of intimacy: Sexuality, love and eroticism in modern societies. Cambridge: Polity Press.

Glover, Nikolas, and Carl Marklund. 2009. "Arabian nights in the midnight sun? Exploring the temporal structure of sexual geographies." Historisk Tidskrift I29:3, 487-5II.

Goffman, Erving. 1963. Stigma: Notes on the management of spoiled identity. Englewood Cliffs, NJ: Prentice-Hall.

Grofman, Bernard, and Arend Lijphart. 2002. The Evolution of electoral and party systems in the Nordic countries. New York: Agathon.

Gustafsson, Harald. 2007. Nordens historia: En europeisk region under 1200 år. 2nd ed. Lund: Studentlitteratur.

Halberstam, Judith. 2005. In a queer time and place: Transgender bodies, subcultural lives. New York: New York University Press.

Halldén, Gunilla, Margareta Hydén, and Karin Zetterqvist Nelson. 2003. "Familjeliv och homosexualitet." In Nätverksfamiljen. Eds. Margareta Bäck-Wiklund and Thomas Johansson, I72-92. Stockholm: Natur och Kultur. 
Halley, Janet E. 200I. "Recognition, rights, regulation, normalisation: Rhetorics of justification in the same-sex marriage debate." In Legal recognition of same-sex partnerships: A study of national, European and international law. Eds. Robert Wintemute and Mads Andenæs, 97-IIr. Oxford and Portland: Hart Publishing.

Hallgren, Hanna. 2008. När lesbiska blev kvinnor. Göteborg: Kabusa.

Halonen, Tarja. I980. "Homoseksuaalien asema tänään Suomessa." Oikeus II:3, I93-96.

Halperin, David M. I990. One hundred years of homosexuality: And other essays on Greek love. New York: Routledge.

- . 2002. How to do the history of homosexuality. Chicago: University of Chicago Press.

Halsos, Martin. 2001. \$213 $i$ almindelig borgerlig straffelov av 1902. Homoseksualitet $i$ Norge og rettslige sanksjoner mot den fra slutten av I800-tallet til 1972, Oslo: Universitetet i Oslo.

- .2007. "Norway 1842-1976: When public interest demands." In Criminally queer: Homosexuality and the law in modern Scandinavia. Eds. Jens Rydström and Kati Mustola, 9I-Ir6. Amsterdam: Aksant.

Halvorsen, Kristin, and Ingolf Håkon Teigene. 2004. Rett fra hjertet. Oslo: Gyldendal.

Halvorsen, Rune. 1998. "The ambiguity of gay and lesbian marriages: Change and continuity in the symbolic order." In Scandinavian homosexualities: Essays on gay and lesbian studies. Ed. Jan Löfström, 207-32. Binghamton, NY: Haworth Press.

Hammack, Phillip L., and Bertram J. Cohler. Eds. 2009. The story of sexual identity: Narrative perspectives on the gay and lesbian life course. Oxford: Oxford University Press.

Hannesson, Haukur. 1999. "Um orð," Samtakafréttir (July 1999).

Hansen, Bent, and Henning Jørgensen. 1993. "The Danish partnership law: Political decision making in Denmark and the National Danish Organization for Gays and Lesbians." In The third pink book: A global view of gay and lesbian liberation and oppression. Eds. Aart Hendriks, Rob Tielman, and Evert van der Veen, 86-99. Buffalo, NY: Prometheus Books.

Haraway, Donna. 1988. "Situated knowledges: The science question in feminism and the privilege of partial perspective." Feminist Studies I4:3, 575-599.

Harris, Angela P. 2006. "From Stonewall to the suburbs? Toward a political economy of sexuality." William and Mary Bill of Rights Journal I4:4, I539-82.

Hartmann, Heidi. 1997 (1979). "The unhappy marriage of Marxism and feminism: Towards a more progressive union." In The second wave: A reader in feminist theory. Ed. Linda Nicholson, 97-I22. New York: Routledge.

Hegna, Kristinn, Hans W. Kristiansen, and Bera Ulstein Moseng. 1999. Levekår og livskvalitet blant lesbiske kvinner og homofile menn. Oslo: Nova.

Herburt, Kim. 2009. "Sadomasochism i svenska uppslagsverk: En historia om misshandel, våldtäkter och lustmord." Historisk Tidskrift I29:3, 4II-528.

Herdt, Gil. 1994. Ed. Third sex, third gender: Beyond sexual dimorphism in culture and history. New York: Zone Books.

Hicks, Stephen. 2005. "Is gay parenting bad for kids? Responding to the "very idea of difference' in research on lesbian and gay parents." Sexualities 8:2, 153-68.

Hirschfeld, Magnus. 1904. "Das Ergebnis der statistischen Untersuchungen über den Prozentsatz der Homosexuellen.” Jahrbuch für sexuelle Zwischenstufen 6, III-78. 
Hoad, Neville. 2006. African intimacies: Race, homosexuality, and globalization. Minneapolis: University of Minnesota Press.

Hobsbawm, Eric J. 1994. Age of extremes: The short twentieth century 19I4-I99I. London: Joseph.

Hodgson, John H. 1967. Communism in Finland: A history and interpretation. Princeton, NJ: Princeton University Press.

Honneth, Axel. 2003. Kampf um Anerkennung: Zur moralische Grammatik sozialer Konfikte. Frankfurt am Main: Suhrkamp.

Isaksson, Emma, and Lena Lennerhed. Eds. 2007. Partnerskapslagen: Ett vittnesseminarium om partnerskapslagens tillkomst. Stockholm: Samtidshistoriska institutet.

Johansson, Kjell E. Ed. 1996. Reformer, välfärd, trygghet: Jörn Svensson 6o år. Stockholm: Carlsson.

Jones, Caroline. 2005. "Looking like a family: Negotiating bio-genetic continuity in British lesbian families using licensed donor insemination." Sexualities 8:2, 22I-37.

Jones, James H. 1997. Alfred C. Kinsey: A public/private life. New York: Norton.

Jónsdóttir, Jóna Ingibjörg. 1994. Könnun á kynhegđun og pekkingu á alnami. Reykjavík: Landlæknisembættið: Landsnefnd um alnæmisvarnir.

Jónsdóttir, Jóna Ingibjörg, and Sigríður Haraldsdóttir. 1998. Kynhegđun og pekking á alnami. Reykjavík: Landlæknisembættið.

Jonsson, Gudmundur. 200I. "The Icelandic welfare state in the twentieth century." Scandinavian Journal of History 26:3, 249-67.

Jordåen, Runar. 2003. "Frå synd til sjukdom? Konstruksjonen av mannleg homoseksualitet i Noreg 1886-1950.” Hovudfagsoppgåve i historie. Bergen: Bergen University.

Jordan, Mark D. 2005. Blessing same-sex unions: The perils of queer romance and the confusions of Christian marriage. Chicago: University of Chicago Press.

Juul-Jensen, Palle. I996. I statens tjeneste. Højbjerg: Hovedland.

Juvonen, Tuula. I998. "Swedish love, or all Swedish men are homosexuals." Paper presented at Rosa moln och blå dunster. Nordisk feministisk studentkonferens, University of Stockholm, Sweden, 25-27 September.

- . 2002. Varjoelämää ja julkisia salaisuuksia. Tampere: Vastapaino.

Karlsson, Gunnar. 2000. Iceland's IIoo years: The history of a marginalised society. London: C. Hurst.

Karvonen, Lauri. 1993. "In from the cold? Christian parties in Scandinavia." Scandinavian Political Studies I6:I, 25-48.

Kettunen, Pauli. 1997. “The society of virtuous circles." In Models, modernity and the Myrdals. Ed. Pauli Kettunen. Helsinki: Renvall Institute Publications.

Kinsey, Alfred C., Wardell B. Pomeroy, and Clyde E. Martin. 1948. Sexual behavior in the human male. Philadelphia and London: W. B. Saunders.

Kinsey, Alfred C., Wardell B. Pomeroy, Clyde E. Martin, and Paul H. Gebhard. I953. Sexual behavior in the human female. Philadelphia and London: W. B. Saunders.

Koch, Lene. 2000. Tvangssterilisation i Danmark 1929-67. København: Gyldendal.

Korpi, Walter. 2000. Contentious institutions: An augmented rational-actor analysis of the origins and path dependency of welfare state institutions in the Western countries. Meddelande från Institutet för social forskning nr. 2000:4. Stockholm: Swedish Institute for Social Research. 
Kristiansen, Hans W. 2008. Masker og motstand: Diskré homoliv i Norge 1920-I970, Oslo: Unipub.

Kristinsson, Thorvaldur. 2000. "Island: Att ta sin plats." lambda nordica 6 (2000):2-3, II $2-25$.

Krouse, Matthew. Ed. 1993. The invisible ghetto: Lesbian and gay writing from South Africa. Johannesburg: COSAW.

Kuefler, Mathew. Ed. 2006. The Boswell thesis: Essays on Christianity, social tolerance, and homosexuality. Chicago: University of Chicago Press.

Kulick, Don. 2005. "Inledning." In Queersverige. Ed. Don Kulick, 9-22. Stockholm: Natur och Kultur.

Kuosmanen, Paula. 2009. "Erkännandet av finländska regnbågsfamiljer som medborgare - inom familjepolitik, lagstiftning och social- och hälsovårdstjänsten r9902007." In Regnbågsfamiljers ställning i Norden. Oslo: NIKK.

Kurtz, Stanley. 2004. "The end of marriage in Scandinavia." The Weekly Standard, February 2.

Laumann, Edward O., John H. Gagnon, Robert T. Michael, and Stuart Michaels. I997. The social organization of sexuality: Sexual practices in the United States. Chicago: University of Chicago Press.

Lennerhed, Lena. 1994. Frihet att njuta: Sexualdebatten i Sverige på rg6o-talet. Stockholm: Norstedts.

Lever, Maurice. 1985. Les bûchers de Sodome. Paris: Fayard.

Lévi-Strauss, Claude. 1949. Les structures élémentaires de la parenté. Paris: Presses universitaires de France.

Lindholm, Margareta, and Arne Nilsson. 2002. En annan stad: Kvinnligt och manligt bomoliv 1950-1980. Stockholm: Alfabeta/Anamma.

Lindström, Susanne. 2005. Kampen om rummet: En studie av heteronormativitet $i$ Svenska kyrkan. Umeå: Umeå universitet.

Ljunggren, Jens. 2009. Inget land för intellektuella: 68-rörelsen och svenska vänsterintellektuella. Lund: Nordic Academic Press.

Love, Heather. 2007. Feeling backward: Loss and the politics of queer history. Cambridge, MA: Harvard University Press.

- . 2009. "The art of losing." In Lost and found: Queerying the archive. Eds. Mathias Danbolt, Jane Rowley, and Louise Wolthers. Copenhagen: Nikolaj, Copenhagen Contemporary Art Center.

Lund, Allan A. 2006. I seng med romerne: Kon og sex $i$ det antikke Rom. København: Museum Tusculanum.

Lundberg, Urban. 2003. Juvelen i kronan: Socialdemokraterna och den allmänna pensionen. Stockholm: Hjalmarson \& Högberg.

Lunden, Birgit. 1997. A comparative study of the development of HIV-preventive strategies in Norway and Sweden. Oslo: n. p.

Lützen, Karin. 1998. "Gay and lesbian politics: Assimilation or subversion? A Danish perspective" in Scandinavian homosexualities: Essays on gay and lesbian studies. Ed. Jan Löfström, 233-244. Binghamton, NY: Haworth Press.

- . 2000. Lützen, Karin. "Nogle ideologisk-moralske rødder til velfærdsstatens familiepolitik." Arbejderhistorie 4, 4-I5. 
Magnusson, Jan. 2000. Ed. Den nordiska homorörelsen under efterkrigstiden. Special issue of lambda nordica 6:2/3.

Manalansan IV, Martin F. 2005. "Race, violence, and neoliberal spatial politics in the global city." Social Text 23

Markussen, Turid. 2002. "Med skeivt blikk på feministisk kritikk: Foucault, feminisme og partnerskapsloven." In Kjønnsrettferdighet: Utfordringer for feministisk politikk. Ed. Cathrine Holst, 23I-255.

Martin, Claude, and Irène Théry. 20or. "The PaCS and marriage and cohabitation in France." International Journal of Law, Policy and the Family I5:I, I35-58.

Mayes, David G. 2004. "Finland: The Nordic insider." Cooperation and Conflict. 39:2, I85-92.

Melby, Kari, Anu Pylkkänen, Bente Rosenbeck, and Christina Carlsson Wetterberg. Eds. 2000. The Nordic model of marriage and the welfare state. Copenhagen: Nordic Council of Ministers.

Melby, Kari, Anu Pylkkänen, Bente Rosenbeck, and Christina Carlsson Wetterberg. 2006. Inte ett ord om kärlek: Äktenskap och politik i Norden ca I850-I930. Göteborg: Makadam.

Merin, Yuval. 2002. Equality for same-sex couples: The legal recognition of gay partnerships in Europe and the United States. Chicago: University of Chicago Press.

Mesner, Maria, and Gudrun Wolfgruber. 2006. Eds. The policies of reproduction at the turn of the 2Ist century: The cases of Finland, Portugal, Romania, Russia, Austria, and the US. Innsbruck: StudienVerlag.

Mielchen, Stefan. 2001. Die Homo-Ehe: Dokumentation und Ratgeber. Hamburg: Himmelstürmer Verlag.

Morgan, Kimberly J. 2006. Working mothers and the welfare state: Religion and the politics of work-family policies in Western Europe and the United States. Palo Alto, CA: Stanford University Press.

Moxnes, Halvor. 20or. "Fra kulturelt hegemoni til ideologisk getto: Homofili-debatten i Den norske kirke fra I950 til 2000." In Norsk bomoforskning. Eds. Marianne C. Brandsæter, Turid Eikvam, Reidar Kjær, and Knut Olav Åmås. Oslo: Universitetsforlaget.

Murray, Stephen O., and Will Roscoe. Ed. 1998. Boy-wives and female husbands: Studies of African homosexualities. New York: St. Martin's Press.

Mustola, Kati. 20or. "Wetterhoff, Adolf Fredrik (Fritz)." In Who's who in gay and lesbian history: From antiquity to World War II. Eds. Robert Aldrich and Garry Wotherspoon, 48I-2. London and New York: Routledge.

- . 2007. "Finland 1889-1999: A turbulent past." In Criminally queer: Homosexuality and the law in modern Scandinavia. Eds. Jens Rydström and Kati Mustola, 215-50. Amsterdam: Aksant.

Mylly, Juhani, and R. Michael Berry. Eds. 1987. Political parties in Finland: Essays in history and politics. Second revised edition. Turku: Turun yliopisto.

Nanda, Serena. 1999. Neither man nor woman: The Hijras of India. Belmont, CA: Wadsworth.

Nordstrom, Byron J. 2000. Scandinavia since 1500. Minneapolis: University of Minnesota Press. 
Norrhem, Svante. 20or. Den hotfulla kärleken: Homosexualitet och vanlighetens betydelse. Stockholm: Carlsson.

Nygård, Mikael. 2003. Välfärdsstaten, partierna och marknaden: Den välfärdsideologiska förändringen inom fyra finländska partier under I99o-talet. Åbo: Åbo akademis förlag.

Øie, Kjell Erik. 1995. "Partnerskapsloven - en politisk kamp der homoene seiret." In Med regnbuen som våpen. Ed. Jon Gunnar Arntzen. Oslo: Antinoos forlag.

Olsen, Bjørn Gunnar. I983. To kvinner. Karen-Christine Friele og Wenche Lowzow forteller til Bjørn Gunnar Olsen. Oslo: Atheneum.

Östberg, Kjell. 2002. 1968 när allting var i rörelse: Sextiotalsradikaliseringen och de sociala rörelserna. Stockholm: Prisma.

Patterson, Charlotte J. I995. "Families of the lesbian baby boom: Parents' division of labor and children's adjustment." Developmental Psychology 31:I, II5-23.

Penrose, Walter. 200I. "Hidden in history: Female homoeroticism and women of a 'third nature' in the South Asian past." Journal of the History of Sexuality Io:I, 3-39.

Petersen, Klaus. 2000. "Socialdemokrati, familiepolitik, velfærdstat i Danmark 19302000." In The Nordic model of marriage and the welfare state. Eds. Kari Melby, Anu Pylkkänen, Bente Rosenbeck, and Christina Carlsson Wetterberg. Copenhagen: Nordic Council of Ministers.

Petersson, Stig-Åke. 2000. "En svensk homorörelse växer fram: RFSL i950-2000.” In Homo i folkhemmet: Homo- och bisexuella i Sverige 1950-2000. Ed. Martin Andreasson, II-35. Göteborg: Anamma.

Pettersson, Åke. 1977. Ett bedårande barn av sin tid: Några kapitel om Karl Gerhard. Göteborg: Stegeland.

Puar, Jasbir K. 2007. Terrorist assemblages: Homonationalism in queer times. Durham, NC and London: Duke University Press.

Rauch, Jonathan. 2004. Gay marriage: Why it is good for gays, good for straights, and good for America. New York: Times Books.

Regnbågsfamiljers ställning i Norden: Politik, rättigheter och villkor. 2009. NIKK Publikationer 2009:I. Oslo: NIKK.

Robinson, Paul. 2005. Queer wars: The new gay right and its critics. Chicago: University of Chicago Press.

Rokkan, Stein. 1970. Citizens, elections, parties: Approaches to the comparative study of the processes of development. With Angus Campbell. Oslo: Scandinavian University Books.

Rosell, Johan. 20oI. "Karl Gerhard." In Who's who in gay and lesbian history: From antiquity to World War II. Eds. Robert Aldrich and Garry Wotherspoon, I79. London and New York: Routledge.

Rosen, Wilhelm von. I994. "A short history of gay Denmark, I63I-I989: The rise and the possibly happy end of the Danish homosexual." Nordisk Sexologi I2, I25-36.

- . 1999. "Pornografiaffæren i 1955." Zink no. 2.

- . 2007. "Denmark 1866-1976: From sodomy to modernity." In Criminally queer: Homosexuality and the law in modern Scandinavia. Eds. Jens Rydström and Kati Mustola, 6I-9o. Amsterdam: Aksant.

Rosenberg, Tiina. 2002. Queerfeministisk agenda. Stockholm: Atlas.

Ross, Becki L., and Catharina Landström. 1999. "Normalizing versus adversity: Lesbian identity and organizing in Sweden and Canada." In Women's organizing and 
public policy in Canada and Sweden. Eds. Linda Briskin and Mona Eliasson, 31046. Montreal: McGill University Press.

Rothblum, Esther D., Kimberly F. Balsam, and Sondra E. Solomon. 2008. "Comparison of same-sex couples who were married in Massachusetts, had domestic partnerships in California, or had civil unions in Vermont." Journal of Family Issues 29:I, 48-78.

Rubin, Gayle. 1975. "The Traffic in Women." In Toward an anthropology of women. Ed. R. Reiter. New York: Monthly Review Press.

- . 1993 (1984). “Thinking sex: Notes for a radical theory of the politics of sexuality.” In Gay and lesbian studies reader. Eds. Henry Abelove, Michèle Aina Barale, and David M. Halperin. New York and London: Routledge.

Rupp, Leila J. 200I. “Toward a global history of same-sex sexuality.” Journal of the History of Sexuality 10:2, 287-302.

Ryan-Flood, Róisin. 2005. "Contested heteronormativities: Discourses of fatherhood among lesbian parents in Sweden and Ireland.” Sexualities 8:2, 189-204.

- . 2009. Lesbian motherhood: Gender, families and sexual citizenship. Basingstoke: Palgrave Macmillan.

Rydgren, Jens, and Anders Widfeldt. 2004. Från Le Pen till Pim Fortuyn: Populism och parlamentarisk högerextremism $i$ dagens Europa. Stockholm: Liber.

Rydström, Jens. I996. "Queer teori och historia." lambda nordica 2:3-4, 8I-99.

- .2003. Sinners and citizens: Bestiality and homosexuality in Sweden, I880-I950. Chicago: University of Chicago Press.

- . 2005. "Solidarity with whom? The international gay and lesbian rights movement and apartheid." In Sex and Politics in South Africa. Eds. Neville Hoad, Karen Martin, and Graeme Reid, 34-49. Cape Town: Double Storey, 2005.

- . 2007a. "Greenland and the Faroe Islands, I866-I988: Nordic peripheries." In Criminally queer: Homosexuality and the law in modern Scandinavia. Eds. Jens Rydström and Kati Mustola, I45-82. Amsterdam: Aksant.

- .2007b. "Sweden, 1864-1978: Beasts and beauties." In Criminally queer: Homosexuality and the law in modern Scandinavia. Eds. Jens Rydström and Kati Mustola, I83-2I4.

- . 2007c. "Piska och morot: HBT mellan stat och folkrörelse, 1944-2007". In Staten som vän eller fiende? Individ och sambälle i svenskt 19oo-tal, by Marika Hedin, Urban Lundberg, Jens Rydström, and Mattias Tydén, 157-92. Stockholm: Institutet för framtidsstudier.

- . 2008. "Legalising love in a cold climate. The history, consequences, and recent developments of registered partnership in Scandinavia." Sexualities II:I-2, I93-226.

Rydström, Jens, and Kati Mustola. 2007. Eds. Criminally queer: Homosexuality and the law in modern Scandinavia. Amsterdam: Aksant.

Sabatier, Paul A., and Hank C. Jenkins-Smith. 1993. Policy change and learning: An advocacy coalition approach. Boulder, CO: Westview Press.

Sang, Tze-Lan D. 2003. The emerging lesbian: Female same-sex desire in modern China. Chicago: University of Chicago Press.

Scappucci, Gioia. 2000. "Court of First Instance refuses to recognize Swedish 'Registered Partnership' rights and duties.' European Public Law 6, 355.

Schalow, Gordon. I993. "The invention of a literary tradition of male love: Kitamura Kigin's Iwatsutsuji." Monumenta Nipponica 4I:I, I-3I. 
Schimmel, Roland, and Stefanie Heun. 200o. "The legal situation of same-sex partnerships in Germany: An overview." In Legal recognition of same-sex partnerships: A study of national, European and international law. Eds. Robert Wintemute and Mads Andenæs, 575-90. Oxford and Portland: Hart Publishing.

Sedgwick, Eve Kosofsky. 1990. Epistemology of the closet. Berkeley: University of California Press.

Seehuus, Jonas Rein. 2009. Rødt, bvitt og skrått: Homofle og lesbiske i Norge gjennom 60 år. Oslo: NRK.

Silverstolpe, Fredrik, Greger Eman, Dodo Parikas, Jens Rydström, and Göran Söderström. 1999. Sympatiens hemlighetsfulla makt: Stockholms homosexuella, I860-1960. Stockholm: Stockholmia.

Söderström, Göran. I999. "Homosexuella i vardagslivet." In Sympatiens hemlighetsfulla makt: Stockholms homosexuella, 1860-1960, by Fredrik Silverstolpe, Greger Eman, Dodo Parikas, Jens Rydström, and Göran Söderström, 502-521. Stockholm: Stockholmia.

Söderström-Anttila, Viveca, Tom Blomqvist, Tuija Foudila, Maritta Hippeläinen, Henri Kurunmäki, Rita Siegberg, Maija Tulppala, Merja Tuomi-Nikula, Sirpa Vilska, and Outi Hovatta. 2002. "Experience of in vitro fertilization surrogacy in Finland." Acta Obstetricia et Gynecologica Scandinavica 81, 747-52.

Søland, Birgitte. 1998. "A queer nation? The passage of the gay and lesbian partnership legislation in Denmark, I989.” Social Politics 5:I, 48-69.

Stacey, Judith. 1996. In the name of the family: Rethinking family values in the post-modern age. Boston: Beacon Press.

- . 2006. "Gay parenthood and the decline of paternity as we knew it." Sexualities 9:I, $27-55$.

Stacey, Judith, and Timothy J. Biblarz. 200I. “(How) Does the sexual orientation of parents matter?" American Sociological Review 66:2, 159-83.

Stone, Deborah. 2002 [1988]. Policy paradox: The art of political decision making. New York: Norton.

Størksen, Ingvill. 2000. "Homofili og politikk: En komparativ analyse av verdiendringer og meningskoalisjoner bak vedtaket av partnerskapsloven i Danmark og Norge.” Hovedoppgave ved Institutt for sammenlignende politikk. Bergen: Bergen University.

Storr, Merl. I999. Ed. Bisexuality: A critical reader. London: Routledge.

Stryker, Susan. 2005. "The Compton's Cafeteria riot in I966: The radical roots of the contemporary transgender movement." Critical Moment issue I2, pp. 5, I9.

Sullivan, Andrew. 2004. "The conservative case." In Same-sex marriage: Pro and con-A reader. Ed. Andrew Sullivan. New York: Vintage Books.

Sundberg, Jan. 1996. Partier och partisystem i Finland. Esbo: Schildt.

Sundberg, Stina. 2002 "Vi ropade 'daghem åt alla!' Men aldrig förstärktes våra led med heterofila röster som ropade slagord för vår kamp.” In Kärlek, makt och systerskap зo år av kvinnokamp. Ed. Lena Olsson. Göteborg: Göteborgs stadsmuseum.

Svéd, Georg. 2000. "När aids kom till Sverige: eller Aids angår alla - en liten betraktelse om när aids inte angick någon eftersom det bara drabbade bögar och knarkare ..." In Homo i folkhemmet: Homo- och bisexuella i Sverige, 1950-200o. Ed. Martin Andreasson, 226-243. Stockholm: Anamma 2000. 
Svensson, Ingeborg. 2007. Liket i garderoben: En studie av sexualitet, livsstil och begravning. Stockholm: Normal.

Svensson, Jörn. 1975. Du skall ta ledningen och makten: Om socialismens uppbyggnad i Sverige. Stockholm: Arbetarkultur.

Thorsell, Eric. 1981. En homosexuell arbetares memoarer: Järnbruksarbetaren Eric Thorsell berättar. Sammanställd av Fredrik Silverstolpe. Stockholm: Barrikaden.

Thorvaldsdóttir, Thorgerdur. 2007. "Iceland 1869-I992: From silence to rainbow revolution." In Criminally queer: Homosexuality and the law in modern Scandinavia. Eds. Jens Rydström and Kati Mustola, II7-44. Amsterdam: Aksant.

Traustadóttir, Rannveig, and Thorvaldur Kristinsson. 2009. "Rainbow families in Iceland.” In Regnbågsfamiljers ställning i Norden: Politik, rättigheter och villkor. Ed. Jennie Westlund. Oslo: NIKK.

Tydén, Mattias. 2002. Från politik till praktik: De svenska steriliseringslagarna, I935-1975. Stockholm: Almqvist \& Wiksell International.

Ulvros, Eva Helen. 20or. Sophie Elkan: Hennes liv och vänskapen med Selma Lagerlöf. Lund: Historiska media.

Vallgårda, Signild. 2003. Folkesundhed som politik: Danmark og Sverige fra I930 til i dag. Copenhagen: Magtudredningen.

- . 2004. "Tvang eller frivillighed: Om aids-lovgivning i Danmark og Sverige." Magasinet Humaniora (February).

Vanita, Ruth, and Saleem Kidwai. Eds. 20or. Same-sex love in India. London: St. Martin's Press.

Varnell, Paul. 2006. "Do gays want to marry?" (ıo May 2006) http://www.indegayforum.org/news/show/30943.htm (accessed I7 September 2010).

Veer, Peter van der. 2006. "Pim Fortuyn, Theo van Gogh, and the politics of tolerance in the Netherlands." In Political theologies: Public religions in a post-secular world. Eds. Hent de Vries and Lawrence E. Sullivan, 527-538. New York: Fordham University Press.

Veggeland, Noralv. 2007. Paths of public innovation in the global age: Lessons from Scandinavia. Northampton, MA: Edward Elgar.

Waaldijk, Kees. 200I. "Small change: How the road to same-sex marriage got paved in the Netherlands." In Legal recognition of same-sex partnerships: A study of national, European and international law. Eds. Robert Wintemute and Mads Andenæs, 43764. Oxford and Portland: Hart Publishing.

- . 2004. "Others may follow: The introduction of marriage, quasi-marriage, and semimarriage for same-sex couples in European countries." New England Law Review $38: 3,569-89$.

Wallace, Lee. 2003. Sexual encounters: Pacific texts, modern sexualities. Ithaca, NY: Cornell University Press.

Warner, Michael. 1999. The trouble with normal: Sex, politics, and the ethics of queer life. New York: The Free Press.

Wasniowski, Andréaz. 2007. Den korrekta avvikelsen: Vetenskapsanvändning, normalitetssträvan och exkluderande praktiker hos RFSL, 1950-1970. Umeå: Holzweg.

Weeks, Jeffrey. 2007. The world we have won: The remaking of erotic and intimate life. London: Routledge. 
Weeks, Jeffrey, Brian Heaphy, and Catherine Donovan. 20oI. Same sex intimacies: Families of choice and other life experiments. London: Routledge.

Westerholm, Barbro. 2000. "Partnerskapslagens tillkomst - framför och bakom kulisserna." In Homo i folkhemmet: Homo- och bisexuella i Sverige, 1950-200o. Ed. Martin Andreasson, 244-263. Stockholm: Anamma.

Weston, Kath. 1991. Families we choose: Lesbians, gays, kinship. New York: Columbia University Press.

Widfeldt, Anders. 200I. "The Swedish Centre Party: The poor relation of the family?" In From farmyard to city square? The electoral adaptation of the Nordic agrarian parties. Ed. David Arter, I-30. Aldershot: Ashgate.

Wikner, Pontus. I971. Psykologiska självbekännelser. Stockholm: Askild \& Kärnekull.

Wintemute, Robert. 20or. "Introduction." In Legal recognition of same-sex partnerships: A study of national, European and international law. Eds. Robert Wintemute and Mads Andenæs, I-5. Oxford and Portland: Hart Publishing.

Wintemute, Robert, and Mads Andenæs. 200r. Eds. Legal recognition of same-sex partnerships: A study of national, European and international law. Oxford and Portland: Hart Publishing.

Wong, Andrew D. 2005. “The reappropriation of tongzhi." Language in Society 34, 763-93.

Wu, H. Laura. 2002. "Through the prism of male writing: Representations of lesbian love in Ming-Qing literature." Nannü: Men, women and gender in early and imperial China 4:I, I-34.

Ytterberg, Hans. 200I. "From society's point of view, cohabitation between two persons of the same sex is a perfectly acceptable form of family life': A Swedish story of love and legislation." In Legal recognition of same-sex partnerships: A study of national, European and international law. Eds. Robert Wintemute and Mads Andenæs, 427-36. Oxford and Portland: Hart Publishing.

Zetterqvist Nelson, Karin. 20oI. "Döttrar, söner och homosexuella föräldrar." In Barn $i$ homosexuella familjer. Del B. SOU 2001:Io. Stockholm: Statens offentliga utredningar.

- . 2006. "The construction of an open time dimension in narratives about the becoming of gay and lesbian families: An act of resistance." Gay and Lesbian Psychology Review 7:I, 8-I8.

- . 2007. Mot alla odds: Regnbågsföräldrars berättelser om att bilda familj och få barn. Malmö: Liber.

Zilliacus, Kim O.K. 20or. "New politics' in Finland: The Greens and the Left Wing in the I990s." West European Politics 24:I, 27-54. 


\section{Index}

A

Adeniji, Anna 27, I39, I8I

adoption II-I3, I9, 25, 27-28, 43, 52, 54-55, 63$65,72,74,86,95$, I03-05, I07, I21--223, І26, I39, I44, I45, I48, I49, I50-54, I59, I62, I65, I73-74, I79

aettarmót 85

age of consent $32-33,42,45,62-63,71,182,212$ agrarian parties 9I, I00, I03-04, I69, I95, I98-99 AHF, Arbeidsgrupper for homofil frigjøring 44-45

Ahlberg, Eva 57, I69

AIDS $47-50,54-55,67,77-79,89$, II3, II7, I4O4I, I67, I68, I70, I85

Akanat (Finland) 78

AKP (m-1), Arbeidernes Kommunistparti (marxist-leninistene) (Norway) 43-44, 93

Albania 44

Almedal, Calle 73

Alpýðubandalagið (Iceland) I87, I95

Alpýðuflokkurinn (Iceland) 187, I95

Ammitzbøll, Simon Emil I5I -52

Andersen, Yvonne Herløv 47, IIo

Andersson, Claes i89

Andersson, Gunnar 35, I28-31

Andersson, Yvonne 157

anti-discrimination laws $32-33,45,50-5 \mathrm{I}, 62$, $88,93,95, \mathrm{I} 53-54, \mathrm{I} 62, \mathrm{I} 82, \mathrm{I} 88,200$

Antigone I6-I7

Anttila, Ulla I89

Arbeidernes Kommunistparti (marxist-leninistene), AKP (m-1) (Norway) 43-44, 93

Arbeidernes Ungdomsfylking, AUF ıоo, 200

Arbeiderpartiet (Norway) 89, 98, Ioo-or, I03, I09, I52-53, 200

Århus 5I, 84

Arnøy, Siri Hall Iıо

assimilation I8, 24, 26-28, 68, 87-88, I56, I62

assisted fertilisation $\mathrm{II}-\mathrm{I} 3,27,36-37,55,64-65$, 86, I05, I22-24, I26, I40, I45-46, I48-5I, I53-54, I59, I65, I73-74, I82
Astroy, Vivi 39

Atassut (Greenland) 6o, 106, I96

Attling, Efwa 64-65, I40

AUF, Arbeidernes Ungdomsfylking Ioo, 200

Axgil, Axel 53, 70, 127, I90

Axgil, Eigil 53, I27

B

Badgett, M. V. Lee 3I-32, I3O-3I

Baldursson, Guðni 59, 75, I97

Balsam, Kimberley 35

Bandalag Jafnaðarmanna (Iceland) 94, I97

Banens, Maks 35

BBF, Bøssernes Befrielses Front (Denmark) 42, 79, 84, I69

Bech, Henning 26, 27, 28, 35, I80, I82

Belgium I30

Bergen 44-45

Berget, Grete roo

Bibin, Thomas 96

Biblarz, Timothy 36

bisexuality I5, 21, I09, I47, I61, I64, I75, I80, 207-08, 2I9

Bondevik, Kjell Magne го7, II8, I53

Bønnelykke, Per Kleis 7I-72, 89, I68-69

Borrillo, Daniel 34

Bøssernes Befrielses Front, BBF (Denmark) 42, 79, 84, I69

Bradley, David 40

Brundtland, Gro Harlem Ioo

Brustad, Sylvia I52 $^{2}$

Butler, Judith I6-I7, I70

C

California I6, 35

Carlgren, Andreas I03, I09, I69, I80

Carlsson, Ingvar IOI-02, I98

Carlsson, Kent ro9, III, 200

catachresis I7, I7O

Centre Democrats (Denmark) IIo

centre parties 9I, IO3-IO4, I64, I69 
Centre Party (Faroes) 62, I96, 201

Centre Party (Finland) 103, I69

Centre Party (Norway) I03, IIo, I55, I69

Centre Party (Sweden) 20, 57, I03, I09, I2O, I58-59, I69, I80

Chenier, Elise I7, I8o

child custody II, I3-I4, I9, 52, 59, 75, III, I2I, I48, I64

children II-I5, I8-2I, 34-37, 52, 59, 64-65, 74-75, $84,87-88,98$, Iо5-06, III-I2, II 7 , І23-26, I30-3I, I37-40, I44-45, I47-52, I54-55, I6I$65, \mathrm{I} 67-69, \mathrm{I} 73-77$

China 44

Christian democratic parties 7, 9I, I05, IO7-08, II4

Christian Democrats (Finland) 64, I49

Christian Democrats (Sweden) 57, 91, 97, 107, I57-59, I69, I80, I99-200

Christian People's Party (Denmark) 53, II5, 2OI

Christian People's Party (Norway) 55, I07, II8, I53-55, I69, I95

Christiansen, Henning $\mathrm{II6,} 202$

Christopher Street Day 42-43, 59, I50, I6I, I68, I88

Church of Denmark I45, I5I

Church of Finland, Evangelical 64, I23

Church of Finland, Orthodox I23

Church of Iceland 85, I2O-2I, I50, I60

Church of Norway II8-I9, I53, I57, I59

Church of Sweden 97, I20, I57, 160-6I, 205

church wedding II-I2, 52, 75, II2, I2O, I24, I35, I45-46, I5I, I57, I60, I62, I73

church stair wedding 120

citizenship II-I2, 52, 74-75, I24, I46-47

cohabitation $34,4 \mathrm{I}, 5 \mathrm{O}-5 \mathrm{I}, 59,92,98$, IOI, I5O, I54, 159

Cold War 18, 62, II2, I62

Commission on Children in Homosexual Families (Sweden) I73

Commission on Gender Neutral Marriage (Sweden) 157

Commission on Registered Partnership (Finland) 65

Commission on Registered Partnership (Iceland) 75

Commission on Registered Partnership (Sweden) 25, 57, IOI

Commissions on Homosexuals in Society, see Homo-Commissions
Communist Marxist-Leninist Union (revolutionaries), KFML(r) (Sweden) 95-96

Communist Party (Finland) 94

communists 4I, 43-45, 50, 79, 82, 9I-96, I04, IO9, 195

conservative parties $50-53,57,60,62,65,9 \mathrm{I}$, IO5-06, II 3 , II5-II6, I5I-52, I55-I563 I6o, I64, I68-69, I72, I95-96

Conservative Party (Finland), see National Coalition Party

Conservative Party (Norway), see Right Party

Conservative Party (Sweden), see Moderates

Conservative People's Party (Denmark) 5053, II5-II6, I5I

Cooper, Davina 32

Copenhagen $7,42-43,49,5 \mathrm{I}, 54,60,74,80,127$, I63, I7I, I84-85

\section{D}

Dahl, André Oktay ro9

Dahlgren, Eva 64, I40, 189

Dam, Paul 40, 5I, 92, 186

Danish People's Party (Denmark) 108, I5I

Danish State Railways II8

Dansk Folkeparti (Denmark) I08, I5I

Davidsen, Agnethe $\quad$ I22

Davidsen, Bogi $6 \mathrm{I}$

Demokratiska Förbundet för Finlands Folk, DFFF (Finland) 63, 93-95, III, I68

Denmark $7, \mathrm{I} 3,26,28,33,37,40-42,47-49,5^{\mathrm{I}}-$ 54, 56, 67, 69-70, 75, 79, 83-84, 89, 98-10о, IO3-O4, IIO, II5-I8, I22, I26-27, I33, I37-38, I40, I42-43, I45-49, I5I-52, I6I, I63, I68-74, I79-82, I84, I86, I98, 208

Der Kreis (Switzerland) 7I

DFFF, Demokratiska Förbundet för Finlands Folk (Finland) 63, 93-95, III, I68

Dittberner, Mareike 34

divorce 29, 35, 40-4I, 7I, II2, I28-30, I34, I46

DNF' 48 , Det Norske Forbund av 1948 (Norway) $42-45,48,54-55,70,72-73,83,86-87$, 92-93, I00, 169

Donner, Jörn I89

donors, see sperm donors

Duggan, Lisa $29-30$

E

Ecumenical Group for Christian Homosexuals, EKHO (Sweden) 83 
Eddudóttir, Lana Kolbrún 74-75, 77-78, 8I, III, I88

Edelman, Lee I9-2I

Einarsdóttir, Anna 28, 75

eingetragene Lebenspartnershaft 34

EKHO, Ekumeniska gruppen för kristna homosexuella (Sweden) 83

Eman, Greger 8o-8I

Environment Party (Sweden) I04, I57

Eskridge, William 30-3I, I3O

Espersen, Lene I5I

Europe 7, I6, I9-20, 33-35, 40, 76, IO4, II2, I38, I68, I7I, 200

European Union 147, I53-I54, 2 IO

extended families I6, 4I, 98, III, I76

F

Family Law Commission (Finland) 63

Family Law Commission (Sweden) 4I, 73

Fåne, Jan-Erik 109, I95

Faroe Islands 2I, 33, 49, 60-62, 67, 95, III, I7I$72, \mathrm{I} 79, \mathrm{I} 88, \mathrm{I} 96,20 \mathrm{I}$

Fassin, Eric 34

fathers $36-37$, I $47-49$, I5I, I68, I74

Fellesrådet for Homofile Organisasjoner, FHO (Norway) 45, 72-73, I84

feminism 24, 27-28, 32, 46, 52, 7I, 75-77, 8I, 83, $86,89-90,98, \mathrm{I} 27, \mathrm{I} 38, \mathrm{I} 62-63, \mathrm{I} 67, \mathrm{I} 69-7 \mathrm{O}$, I $75-76$

FHO, Fellesrådet for Homofile Organisasjoner (Norway) 45, 72-73, I84

Finland $13,33,37,42,45,48-49,62-67,70,76$, 78, 89, 91, 93-94, 97, Iо2-06, Іо8-09, III, I22-24, I37-38, I49-50, I6I, I63-64, I68-69, I72-74, I79, I82, I85, I89, I94, I99, 206-07

Finlands Landsbygdsparti (Finland) I08, 195

Finnbogadóttir, Vigdis 59, 85, I2I

Finnish Communist Party (Finland) 94

Finnish People's Democratic Alliance, SKDL/DFFF (Finland) 63, 93-95, III, 168

Fólkaflokkurin (Faroes) I96

Folkdemokraterna, SKDL/DFFF (Finland) 63, 93-95, III, I68

Folkpartiet (Sweden) 57, 9I, 97, 157-I59, I68

Fortuyn, Pim 2I

Foss, Per-Kristian 109, 152-53, I64, 200

Foucault, Michel I8, 22, I77

four-leaf clover family I47

Framsóknarflokkurinn (Iceland) 187, 195, 199

France 33-34, 66, 82, 206
Fransson, Urban 158

Fraser, Nancy I8-I9, II2

Free Church, Reykjavík 59

Fremskridtspartiet (Denmark) I08, II5

Fremskrittspartiet (Norway) 55, I08-09, I53, I95

Frevert, Louise I08

Friðarbogin 6I

Friele, Karen-Christine (Kim) 25, 42, 54-56, 72-74, 83-88, I05, I54, I69-70, I8I, I83

frisind $28,180-82$

\section{G}

Gåsland, Anders Io7

Gay Liberals (Sweden) 89, I68

Gay Men's Liberation Front (Denmark) 42, $79,84,169$

gay saunas 48

gender I4-I5, 20, 26, 35, 96, IO2, II2, I3I, I36, I37-4I, I72, I76-77, I80

gender-neutral marriage law I2, 21, 28, 37, 83, 87, I04, I35, I49, I5I-62, I72, 206, 208

Gerhard, Karl 208

Gerhard, Kirsten 34

Germany 33-35, 66

Giddens, Anthony 36, I8I

Gísladóttir, Ingibjörg Sólrun 59, 84, 94, III, I84

Gjellerup, Pia 53, 98--оoo, II6, II8

Glistrup, Mogens Io8

Goffman, Erving 29

Göteborg 8I, IOI, I85

Grande, Trine Skei I56, 2II

Green, Åke Io7

Green Alliance (Finland) 64, IO2, IO4-O5, III, I68, I89, 204

green parties 9I, IO4-O5

Greenland 37, 49, 58-6o, 62, 95, I06, I2I-22, I24, I49, I72, I79, I82, I88, I96, 204

Group Lambda (Norway) 44-45

Grundtvig, Nikolai Frederik Severin 28

Guðfinnsson, Einar 187

H

Häkämies, Kari 65, I03

Halberstam, Judith 20

Halley, Janet 32

Hallgren, Hanna I4O

Halonen, Tarja 63, I02, I09

Halvorsen, Kristin 25, 55, I09-IO, 154-55

Halvorsen, Rune 27 
Hansen, Bent 24, 5I, 53, 89

Hansen, Poul iı6

Haraway, Donna 24

Hartmann, Heidi $75-76$

Haugland, Valgerd Svarstad ${ }_{53}$

Hautala, Heidi I89

Hawaii 7

HBB, Homofil Bevegelse i Bergen (Norway) 45

Helgadóttir, Guðrún 187

Helle, Esko I89

Helmsdal, Finnur 95

Helsinki 45, 63, 88, 94, I05

Hentilä, Jorma 48, 63, 76, 93-94, III, I68, I85, I89, I92, I97, 22I

Hermansson, Anne-Sofie IoI

Heun, Stefanie 34

Hicks, Stephen 36

Hiltunen, Rainer 64-66, I02-03, Io6, I68

hinsegin dagar $16 \mathrm{I}-62,205$

Hirschfeld, Magnus 69, I3I-32

HIV prevention $47-50,54,78,168$

Høie, Bent 109

Holt, Anne ${ }^{152-53}$

Homo Commission (Denmark) 5I-52, 89, I05

Homo Commission (Sweden) 50-51, 56, 67, 82,89 , IOI

Homo Commissions (Iceland) $5 \mathrm{I}^{-} 52,59,84$, III, I5O

Homofil Bevegelse i Bergen, HBB (Norway) 45

homonationalism 2I

homonormativity $18,29,182$

homophile movements $42,67,69-70,77,183,185$

Homosexual Socialists (Sweden) 82

Honneth, Axel I8

Hoydal, Høgni 95, 197

Høyre (Norway) I05-06, I09, I53-156, I64

\section{I}

IA, Inuit Ataqatigiit (Greenland) 95, I96

Iceland I3, 23, 28, 42, 45-46, 49, 5I-52, 58-59, $62,66-67,74-75,77-78,81,84-86,89,94-95$, IO6, III, II4, I2O-2I, I35, I47, I49, I50, I6o64, I68-69, I72, I75, I79, I84-85, I94-96, I99, 20I, 205, 209-IO

Icelandic Language Commission 46

identity II, I5, 22, 24, 27, 79, 8I, 83, I36-37, I4O, I84

IKEA 163
ILGA 8, 24, 8I

Independence Party (Faroes) 196

Independence Party (Iceland) I06, I60, I87, I95

insemination II, I3, 55, 64-65, I26, I4O, I45, I49-50, I53, I59, I73-74

Inuit Ataqatigiit, IA (Greenland) 95, I96

Ireland $36-37$

Íslensk lesbíska 78

Íslensk málnefnd 46

J

Javnaðarflokkurin (Faroes) 95, I96

Jensen, Jens Peder Ioo

Jensrud, Trond Ioo-oI, I09, 200

Jerry's Ladies Clubs 39

Johannesen, John 95

Johnsen, Árni ro6

joint child custody II, I3-I4, I9, 52, 59, 75, III, I2I, I48, I64

Joint Council for Homophile Organisations, FHO (Norway) 45, 72-73, I84

Jordan, Mark D. 3I

Jørgensen, Henning 24, 5 I

Jørgensen, Regine $\quad$ I22

Juul-Jensen, Palle iıo

Juvas, Sören $157-58$

K

Kansandemokraatit (Finland) 63, 93-95, III, I68

Kekkonen, Urho 62

Kettunen, Pauli 18

KFML(r), Communist Marxist-Leninist Union (revolutionaries) (Sweden) 95-96

Kim, Richard 30

Kinsey, Alfred 96, I33, I36, 206

kinship I6-I7, I70

Kivinen, Tiina 64, IO2, IO4-O5

Kjær, Tine 153

Kleppa, Magnhild Meltveit IIo

Knudsen, Grete roo

Kokoomus (Finland) 65, I03, Io6

Koskinen, Johannes I03, I23

Krarup, Søren I5I

Kristdemokraterna (Finland) 64, I49

Kristdemokraterna (Sweden) 57, 91, 97, 107, I57-59, I69, I80, 199-200

Kristelig Folkeparti (Norway) 55, Iо7, II8, I53-55, I69, I95 
Kristeligt Folkeparti (Denmark) 53, II5, $20 \mathrm{I}$

Kristerson, Ulf ro6

Kristiansen, Hans W. I83

Kristillisdemokraatit (Finland) 64, I49

Kristinsson, Thorvaldur 59, 77, 83-87

Krøyer, Peder Severin 53-54

Kuopio I23

Kurtz, Stanley 29

Kvaran, Kristín S. 58, 94

Kvennalistinn (Iceland) 52, 59, 84, 94-95, I96

kynvillingar 45-46, 205

L

Labour Party (Norway) 89, 98, Iоo-oI, I03, IO9, I52-53, 200

Labour Party's Youth League (Norway) roo, 200

Lárusson, Ragnar Fjalar I2I

Lascoumes, Pierre 34

law of standard sequences 32

Law on Homosexual Cohabitation (Sweden) $5 \mathrm{I}$

LBL, National Union for Gays and Lesbians (Denmark) 25, 47, 5I-54, 77, 79, 8I, 89, IIO, II6-I7

Left Alliance (Finland) 63, I02, I89

Left Communist Party, VPK (Sweden) 4I, 50, 92, 109

Left Homo (Finland) 94

Left Party (Denmark) 53, Iо०, Іо3-05, II6, I5I-52

Left Party (Norway) 97, I56, I59

Left Party (Sweden) I04, I09, 157, 159, 207

Left Socialist Party (Denmark) 52, I86

Lehtikuusi, Hannele 64-65, I05, I68, I89

Leósdóttir, Jónina 95

lesbian couples 7 , I2-I3, I5-I6, I9, 25, 35, 40, 56, $64-65,82, \mathrm{I1} 5, \mathrm{I} 23-27, \mathrm{I} 4 \mathrm{O}, \mathrm{I} 47-49, \mathrm{I} 53, \mathrm{I} 65$, $\mathrm{I} 67, \mathrm{I} 73, \mathrm{I} 75-76, \mathrm{I} 89$

lesbian feminists I4, I6, 30, 46, 71, 76, 89, I27, I38, I67, I69, I75, I85

Lesbian Feminists, LF (Sweden) 76, 83

Lesbian Front (Sweden) I69

lesbian separatism $46-47,77-79,89,93,169-70$

lesbians I4-I6, 26-27, 29-3I, 33-36, 39, 43-46, 49, 53-54, 56, 59, 6I, 64-66, 70, 72, 74-79, 8I-82, 86-87, 94, 96, IO5, IIO-II, II8, I22-23, I26, I28-31, I33-36, I38, I40, I42, I44-48, I50, I52-54, I56-57, I59, I63-65, I67-7I, I73, I $75-76$, I 92
Lesbisk Nu! (Sweden) 78

Lévi-Strauss, Claude 16

Liberaalinen Kansanpuolue (Finland) 97

Liberal People's Party (Finland) 97

Liberala Folkpartiet (Finland) 97

liberalism 20, 22, 46, 88-90, 96-97, 103-04, Iо6-08, III, II3, II6, I5I, I55-56, I68, I95-96, 200, 202

Lindblom, Bengt 94

Lindstad, Gro 55

Lipponen, Paavo ro3

Lööw, Maj-Lis IoI-02, III, I45-47

Lowzow, Wenche 56, I05-06, I09, I53-54, I64

Lund, Torben 47, IIO, I68

Lundahl Madsen, Axel (later Axgil) 53, 70, I27, 190

Lützen, Karin 26-27, II2

\section{M}

Mao Tse-tung 93

Mariestad I2O

marital status $7-8, \mathrm{I} 3,37, \mathrm{II} 6-\mathrm{I} 7, \mathrm{I} 33-35, \mathrm{I} 6 \mathrm{O}$

Markussen, Turid 27

Marriage Law Commission (Denmark) 7I, I83, I9I

marriage law commissions 40-4I, 63-64, 7I, 73, I22, I49, I57, I73, I83, I9I

Marxism 4I, 43-44, 75-76, 79, 8I, 93, 95-96

Mendès-Leite, Rommel 35

Merin, Yuval 3I

Miðflokkurin (Faroes) 62, 196, 201

Miljöpartiet (Sweden) I04, I57

Moderates (Sweden) 57, I06, I08, I20, I57-59, I80

Mohr, Anna 78, 82, I69

Mølgaard, Estrella I22

Mustola, Kati 48, 64, 66, I89

Mykines 49

\section{$\mathbf{N}$}

National Coalition Party (Finland) 65, I03, Io6

National Union for Gays and Lesbians, LBL

(Denmark) 25, 47, 5I-54, 77, 79, 8I, 89, IIO, II6-I7

National Union for Sexual Equality, RFSL (Sweden) 4I-42, 47, 58, 70, 73-74, 78, 82, 89, 95-96, I20, I57-58, I63-64, I85, I90-9I

Nave-Herz, Rosemarie 34

Nestius, Hans Ior 
Netherlands 21, 3I, 33, 35, 42, 66, 82, I28, I30-3I, I33-35, I4I-43, I47, 206

New Democracy (Sweden) ro8-09, I95

New York 29, 42, 76

Noack, Turid 35

Nordic Council 40, 62, 66, I79, I88, 193

Nordic Council for Homosexuals, NRH 8I, 193

Norway I2-I3, 25-27, 33, 35, 37, 40, 42-45, 48, 54-56, 69-70, 72-74, 78-79, 86-88, 93, 98, IOO-OI, IO3, IO7-IO, II4, II8-I9, I30, I32, I35, I37-4O, I43, I49, I52-57, I62-63, I68-72, I7475, I79, I82, I83, I9O, I99, 202, 205-08, 210

NOVA report (Norway) I52

NRH, Nordic Council for Homosexuals 8I, 193

Nuuk 60, I22, 204

Ny Demokrati (Sweden) Io8-09, 195

O

Öberg, Jeanette 57

Oedipus I7

Øie, Kjell Erik 25, 48, 55, 89, 100, I07, I68, I8I Ojala, Outi 63, I89

Ólafsdóttir, Margrét Pála 74-75

Olsen, Erik 122

Örkelljunga II9, I20

Oslo 42, 44, 56, 87, 89, IO5-o6, I53

Österbotten 97, I49

Östersund $5^{8}$

\section{$\mathbf{P}$}

Pacs 19, 33-34, 206

paedophilia 77,79

Palme, Lisbet 98

Palme, Olof 98

parental rights $\mathrm{I} 2-\mathrm{I} 33, \mathrm{I} 23, \mathrm{I} 46, \mathrm{I} 48-49, \mathrm{I} 65$

parenthood I5, I23, I25, I38, I47-50, I52, I6I, I $74-75, \mathrm{I} 92,204$

patriarchy $28,45-46,75-77,79,83,89, \mathrm{I} 27, \mathrm{I} 38$, I $75-76$

pensions II2, II7, I43

People's Alliance (Iceland) I87, I95

People's Democrats, SKDL/DFFF (Finland) 63, 93-95, III, I68

People's Party (Faroes) I96

People's Party (Sweden) 57, 91, 97, 157-I59, I68

Persson, Göran I02, I58

Petersson, Stig-Åke 73, 89, I68, I9I

pink dollar $\mathrm{I}_{3}$

Pohjanmaa 97, I49

Poland I8

professionalisation 55, I70

Progress Party (Denmark) 108, II5

Progress Party (Norway) 55, I08-09, I53, I95

Progressive Party (Iceland) I87, I95, 199

Puar, Jasbir I9, 2I

Puisto, Virpa I89

Pykäläinen, Tuija Maaret I89

Q

Qaamaneq (Greenland) 95, I22

queer culture $\mathrm{I} 6, \mathrm{I} 62$

queer criticism 16,156

queer feminism 138,207

queer theory I6-2I, 24, 8I, I24, I38, 205

Qvist, Anna II6-I7

\section{$\mathbf{R}$}

Radical Left Party (Denmark) 52-53, 96, Ioo, IO4, I09, I5I-52, I68, I86

Radicalesbians 76, 192

rainbow families I3, I8-21, 36, 86, I38, I40, I67, I75

Rand, Max 94

Raneskog, Gunde 20, I64

Rasmussen, Henriette 60, 95

recognition I3-I4, I6, I8-22, 25, 28-29, 30, 32$34,36-37,39,46,67,69,7 \mathrm{I}, 76,8 \mathrm{I}, 85-87$, II2, II5, I24-25, I3I, I37, I46, I5I, I6o-62, I64, I67, I70-72, I75-77

Reich, Wilhelm 79

Reinfeldt, Fredrik 106, I08, I20

reproductive technology $\mathrm{II}-\mathrm{I} 3,27,36-37,55$, 64-65, 86, Іо5, І22-24, І26, І40, I45-46, I48-51, I53-54, I59, I65, I73-74, I82

Republican Party (Faroes) 95, I88, I96

Reykjavík 2I, 85-86, I6I-63, I97, 205

Reykjavík Pride I6I-62, 205

RFSL, National Union for Sexual Equality (Sweden) 4I-42, 47, 58, 70, 73-74, 78, 82, $89,95-96$, I20, I57-58, I63-64, I85, I90-9I

Riekkinen, Wille 123

Right Party (Norway) I05-06, I09, I53-I56, I64

Rosen, Wilhelm von 26, 79-80

Ross, Else-Merete 96-97, I09, I97

Rothblum, Esther 35

Rubin, Gayle 5-16, I76

Ruotsalainen Kansanpuolue (Finland) 9I, 97, I49, I89 
Rural Party (Finland) I08, I95

Ryan-Flood, Róisin 36

\section{S}

Saarinen, Terhi 76, 78, I69

Sahlin, Mona II9

Samfylkingin (Iceland) 95

Samlingspartiet (Finland) 65, 103, 106

Samtökin '78 (Iceland) 45-46, 52, 59, 74-75, 84, 86, III, I64, I88, I97

Samuelsen, Rólant 6I

Schimmel, Roland 34

Schmidt, Sanne Yde 8I

Sedgwick, Eve Kosofsky 22

Semionsen, Tom 49

Senterpartiet (Norway) I03, IIO, I55, I69

SETA (Finland) 45, 48, 63-66, 88, 94, I02, I04-06, I85

Signorile, Michael 29

Siumut (Greenland) I49, I96

Sjálfstaeðisflokkurinn (Iceland) Io6, I60, I87, I95

Sjálvstýrisflokkurin (Faroes) I96

Skagen 53-54

Skarpheðinsson, Össur I87

SKDL, Suomen Kansan Demokraattinen Liitto (Finland) 63, 93-95, III, I68

skrád sambúð 59

Slange, Else 75, 77, II6, I27, I45-46, I69-70

Slottner, Erik I07-08

social democracy 20, 68, 8I, 97-Іо3, Іо9-Іо, II4, I64, I68-69, I98-I99

social democratic parties 68, 8I, 9I-92, 94-95, 97-IO3, I09-Io, II4, I64, I69, I98-99

Social Democratic Party (Denmark) 52-53, 98-99, IO4, IIo, II6, I86

Social Democratic Party (Faroes) 95, I96

Social Democratic Party (Finland) 63, IO203, I09, I23, I89

Social Democratic Party (Iceland) I87, I95

Social Democratic Party (Norway) 89, 98, IOO-OI, IO3, IO9, I52-53, 200

Social Democratic Party (Sweden) 50, 56-57, 73, 98, IOI-O4, IO9, II9-2O, I45, I57-58

Social Democratic Women's League (Sweden) 98-99, IOI-O2

Social Democratic Youth League, SSU (Sweden) 73

social democrats $68,82,89-90,99-$-I0O, IO2, IO9-IO, I52, I68
Socialist Alliance (Iceland) 94, I69, I97

Socialist Left Party (Norway) 25, 43-44, 87, 92-93, IO3, IO9-IO, I54-55

Socialist People's Party (Denmark) 40, 5I-53, 71, 92, I86

Socialistisk Folkeparti, SF (Denmark) 40, $5^{\mathrm{I}-53}, 7 \mathrm{I}, 92, \mathrm{I} 86$

Society of 1948 (Denmark) 42, 51, 53, 55, 69-72, I27, I69, I90, I97

Søland, Birgitte $26-27$

Solomon, Sondra 35

Soria Moria Declaration 154

Sosialistisk Venstre, SV (Norway) 25, 43-44, $87,92-93$, IO3, IO9-IO, I54-55

Spaak, Carl-Anton 58

Spedale, Darren 30-3I, I30, I9I

sperm donors 36-37, I4O, I5O-5I, I74, I82

Stacey, Judith 36

staðfest samvist 59

Stafilidis, Tasso Io9

state churches 3I, 64, 69, 85, 97, II8-2I, I23, I25, I45-I46, I5O-5I, I53, I57, I59-6I, 205

state recognition $8, \mathrm{I}_{3}-\mathrm{I} 4, \mathrm{I} 6, \mathrm{I9}, 85$, II2, II5, I24, I37, I62, I67, I75

Statistics Denmark II6-I7

Statistics Greenland I2I, I29

Steenholt, Otto 6o, Io6

Stenius-Kaukonen, Marjatta I89

stepchild adoption I2I, I26, I39, I48-49, I5I, I73, I79

Stephensen, Ólafur I2I

Stockholm 35, 39, 58, 70, 73, IOI, I52, I58, I63, $\mathrm{I} 77, \mathrm{I} 8 \mathrm{O}, \mathrm{I} 85, \mathrm{I} 93,200$

Stonewall 42, 46, 50, I47, I62, I83

Stork, Nina 148

Størksen, Ingvill 26

Strange, Ebba 100

student housing 70

Sullivan, Andrew 29

Suomen Kansan Demokraattinen Liitto, SKDL (Finland) 63, 93-95, III, I68

Suomen Keskusta (Finland) I03, I69

Suomen Maaseudun Puolue (Finland) Io8, I95

Svahn, Birgitta 58

Svenska Folkpartiet (Finland) 9I, 97, I49, I89

Svensson, Ingeborg 192

Svensson, Jörn 4I, 58, 109, I72, I83, 2 I2

Sweden II-I3, I8, 20, 23, 28, 35-37, 40-42, $45^{-}-48,50,56-58,62,65,67,69-70,72^{-73}$, 
78, 82-83, 89, 91-92, 97-98, IOI, IO3-04, IO6-08, II8-20, I30, I35, I37-4I, I43, I47, I50, I57-6o, I6I-63, I68-69, I7I-73, I75, I79-8o, I82, I85, I9O, I92, I98, 200, 202, 205, 207-08

Swedish People's Party (Finland) 9I, 97, I49, I89

\section{$\mathrm{T}$}

Thommessen, Olemic I55

Thordarsson, Ólafur 187

Thorpe, Jeremy 94

Tidaholm 58

Timrå I20

Tjóðveldisflokkurin (Faroes) 34, 95, I88, 196

Tørresdal, Bjørg 154-55

Tórshavn 6I-62

trade unions 42, 46, IOI-O3, II7, I99, 219

transgender $136-37,164-65,176-77,219$

Tryggvadóttir, Margrét I6o

Tuomioja, Erkki I89

Tynkkynen, Oras III

\section{U}

United Kingdom 33, 94

United Left Party (Iceland) 95

United States 7, I6, I9-20, 27, 29-33, 35, 42, $76-77,132,138$

universalism $33-34$

Unmarried Cohabiting Couples' Mutual Home Act (Sweden) 50

Uppsala 70

$\mathrm{V}$

Vallgårda, Signild 47

Vänsterförbundet (Finland) 63, IO2

Vänster-Homosexuella (Finland) 94

Vänsterpartiet (Sweden) 104, I09, I57, 159, 207
Vänsterpartiet Kommunisterna, VPK (Sweden) 4I, 5O, 92, I09

Varnell, Paul I30

Vasemmistoliitto (Finland) 63, IO2

Vasenhomo (Finland) 94

Vennamo, Veikko Io8, I95

Venstre (Denmark) 53, I00, I03-05, II6, I5I-52

Venstre (Norway) 97, I56, I59

Venstresocialisterne (Denmark) 52, 186

Vihreä liitto (Finland) 64, IO2, I04-05, III, I68, I89, 204

virallistettu parisuhde 66

Visby 157

VPK, Vänsterpartiet Kommunisterna (Sweden) 4I, 5O, 92, I09

W

Waaldijk, Kees 3I-33, I82

Warner, Michael 29

Weeks, Jeffrey 24, 36

welfare states I5, 20-2I, 26, 28, 33, 68, IO3, II2, II4, I37-38, I43-44, I63-65, I70, I74-76, I80-8I, 207

Weston, Kate 36

Wikner, Pontus 69, I90

Wikström, Tobias 57,83

Wintemute, Robert 32

Women's List (Iceland) 52, 59, 84, 94-95, I96

$\mathrm{X}$

xenophobia 2I

Y

Ytterberg, Hans 25

Z

Zetterqvist Nelson, Karin 36, I40 